\title{
ZAGOSPODAROWANIE TERENÓW ZAGROŻONYCH POWODZIAMI W WOJEWÓDZTWIE ŁóDZKIM
}




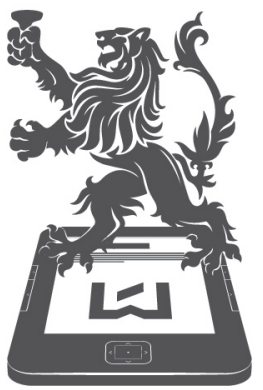

WYDAWNICTWO

UNIWERSYTETU ŁODZKIEGO 
Marta Borowska-Stefańska

\section{ZAGOSPODAROWANIE TERENÓW ZAGROŻONYCH POWODZIAMI W WOJEWÓDZTWIE ŁÓDZKIM}


Marta Borowska-Stefańska - Uniwersytet Łódzki, Wydział Nauk Geograficznych

Katedra Zagospodarowania Środowiska i Polityki Przestrzennej, 90-142 Łódź, ul Kopcińskiego 31

RECENZENT

Tadeusz Siwek

REDAKTOR WYDAWNICTWA UŁ

Iwona Gos

SKŁAD KOMPUTEROWY

$A G E N T$ PR

PROJEKT OKŁADKI

czartart.com: Izabela Surdykowska-Jurek

Zdjęcia wykorzystane na okładce: (C) Depositphotos.com/Peaceful-park-in-spring

Green-field-near-the-river; Summer-landscape-with-river

(C) Copyright by Uniwersytet Łódzki, Łódź 2015

Wydane przez Wydawnictwo Uniwersytetu Łódzkiego

Wydanie I. W.06913.15.0.M

Ark. wyd. 9,1; ark. druk. 9,0

ISBN 978-83-7969-666-6

e-ISBN 978-83-7969-667-3

Wydawnictwo Uniwersytetu Łódzkiego

90-131 Łódź, Lindleya 8

www.wydawnictwo.uni.lodz.pl

e-mail: ksiegarnia@uni.lodz.pl

tel. (42) 6655863 


\section{SPIS TREŚCI}

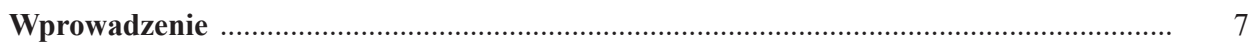

1. Zagospodarowanie terenów zalewowych - wybrane zagadnienia .................................... 17

1.1. Problematyka zagospodarowania i oceny ryzyka powodziowego …….................... 17

1.2. Metody ochrony przed powodziami ..................................................................... 32

2. Zjawiska powodziowe w województwie lódzkim ............................................................ 37

2.1. Charakterystyka dolin rzecznych .................................................................... 37

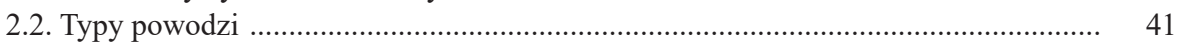

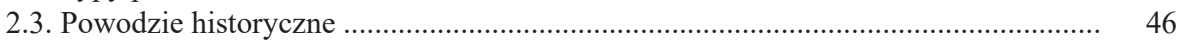

3. Użytkowanie ziemi na terenach zagrożonych powodziami w gminach województwa lódzkiego

3.1. Ogólna charakterystyka zagospodarowania .......................................................... $\quad 55$

3.2. Zróżnicowanie badanych gmin pod względem struktury użytkowania ziemi .......... 59

3.3. Próba typologii ............................................................................................... 72

3.4. Użytkowanie ziemi w wybranych gminach ...................................................... 74

4. Stan zainwestowania przeciwpowodziowego $w$ województwie łódzkim .......................... 87

4.1. Wały przeciwpowodziowe .......................................................................... 87

4.2. Zbiorniki retencyjne .................................................................................... 95

5. Rozklad ryzyka powodziowego w województwie lódzkim - kontekst zagospodarowania

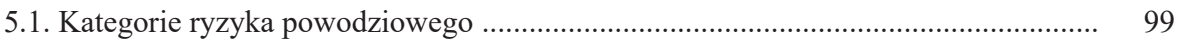

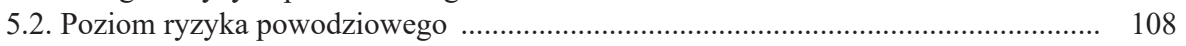

5.3. Porównanie wyników oceny ryzyka powodziowego ............................................... 126

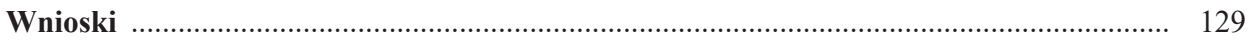

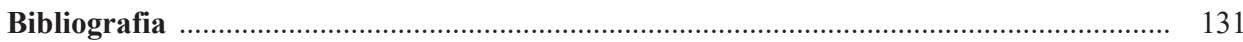

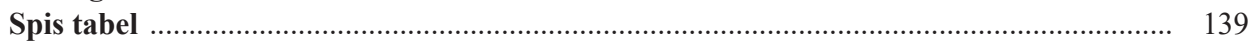

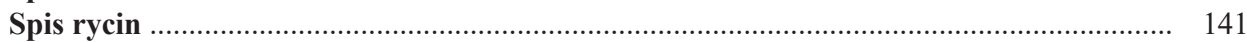

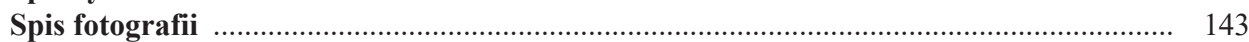





\section{WPROWADZENIE}

Praca poświęcona jest zagadnieniu zagospodarowania terenów zagrożonych powodziami w wybranych gminach województwa łódzkiego. W ostatnich latach powodzie w Polsce są przyczyną zagrożeń dla ludzi oraz ogromnych strat materialnych. Najbardziej narażonymi pod tym względem województwami w naszym kraju są: małopolskie, podkarpackie, śląskie, opolskie i dolnośląskie. Według danych Wydziałów Bezpieczeństwa i Zarządzania Kryzysowego urzędów wojewódzkich z 2010 r., na terenie kraju zagrożonych powodziami było ponad 1000 gmin, w tym: ok. 875 tys. ha użytków rolnych, 86500 budynków mieszkalnych, 2600 budynków użyteczności publicznej, ok. 2000 mostów i ponad 280 oczyszczalni ścieków. Powodzie generują największe straty w Polsce południowej, jednak podczas intensywnych opadów deszczu w półroczu letnim lub wskutek gwałtownego topnienia śniegu czy też wystąpienia zatorów na rzekach w okresie od grudnia do marca zagrożone są również tereny położone w Polsce centralnej, w tym w województwie łódzkim (Zagrożenia okresowe występujące $w$ Polsce 2010).

Wezbrania w obrębie równiny zalewowej należą do zjawisk naturalnych (Kobojek 2010). Niezwykle istotnym zadaniem jest prowadzenie odpowiedniej polityki w zakresie ochrony przeciwpowodziowej. Obecnie odbywają się liczne dyskusje na temat ochrony obszarów zagrożonych powodziami: czy korzystać ze środków technicznych czy też nietechnicznych. Stosowanie dotychczas w Polsce metod ochrony przeciwpowodziowej ograniczało się przede wszystkim do działań technicznych (Bobiński, Żelaziński 1996; Bajorek 2001; Walczykiewicz, Biedroń 2013). Metody te nie są skuteczne oraz doprowadzają do zmian bioróżnorodności na danym obszarze, poprzez zmniejszenie liczby gatunków roślin i zwierząt tam żyjących (Bobiński, Żelaziński 1996; Grocki, Eliasiewicz 2001). Obecnie zmieniło się podejście do ochrony terenów zalewowych. W wyniku wprowadzenia założeń Dyrektywy Powodziowej (2007) na koniec 2013 r. stworzono mapy zagrożenia i ryzyka powodziowego. Dzięki nim każdy może sprawdzić, czy dany teren znajduje się w zasięgu oddziaływania powodzi. Istotne okazuje się pozostawienie „miejsca” dla powodzi, wszędzie tam, gdzie zagrożenie ludności i gospodarki jest niskie. W przypadku znacznego stopnia zurbanizowania terenów nadrzecznych, uprzemysłowienia i prowadzenia gospodarki rolnej istnieją ograniczenia, co do 
możliwości poszerzenia koryta i doliny (Walczykiewicz, Biedroń 2013). Uzależnione jest to od specyfiki obszaru objętego ochroną. Występują wyraźne różnice pomiędzy przebiegiem powodzi w dolinach rzek dużych (tj. Wisła czy Odra) i małych. Za przyczynę olbrzymich strat powstałych w wyniku powodzi w dużej mierze odpowiada stan zagospodarowania dolin rzecznych (Program bezpieczeństwa powodziowego... 2012). W strefie zagrożonej powodziami lokalizowane są obiekty użyteczności publicznej, tj. szkoły, muzea, teatry, obiekty usługowe, w tym stacje paliw, a także obiekty mogące generować wtórne zagrożenia: składowiska odpadów, oczyszczalnie ścieków itp. Na tych obszarach powstają również budowle, które mogą powodować podpiętrzenie wody i w efekcie szersze rozlewiska (źle zaprojektowane mosty, sztuczne zwężenia dolin). Wszystko to, w połączeniu z przekonaniem o niezawodności urządzeń technicznych, doprowadza do ogromnych strat (Bogdańska-Warmuz i in. 2000).

Celem pracy jest ocena zagospodarowania terenów zagrożonych powodziami w gminach województwa łódzkiego, w kontekście potencjalnych negatywnych konsekwencji dla ludzi, środowiska przyrodniczego, dziedzictwa kulturowego i działalności gospodarczej (na podstawie analizy aktualnego stanu zagospodarowania w badanych gminach).

Opracowanie ma charakter statyczny. Wykorzystane w pracy materiały źródłowe pochodzą głównie z lat 2011-2013. Ma to istotne znaczenie dla oceny aktualnego zagospodarowania terenów szczególnego zagrożenia powodziami.

W pracy badaniu podlegały tereny zagrożone powodziami w 21 gminach, położonych w granicach województwa łódzkiego, w zlewniach trzech głównych rzek:

1) Warty - Gidle (gmina wiejska nad Wartą, Mękwą), Radomsko (gmina wiejska, nad Wartą i Radomką), Ładzice (gmina wiejska, nad Wartą), Działoszyn (gmina miejsko-wiejska nad Wartą), Burzenin (gmina wiejska nad Wartą), Zapolice (gmina wiejska nad Wartą i Widawką), Sieradz (gmina wiejska nad Wartą, Myją, Żegliną), Sieradz (miasto nad Wartą i Myją), Warta (gmina miejsko-wiejska nad Wartą), Pęczniew (gmina wiejska nad Wartą), Poddębice (gmina miejsko-wiejska nad Wartą, Nerem), Uniejów (gmina miejsko-wiejska nad Wartą);

2) Pilicy - Żytno (gmina wiejska nad Pilicą), Rozprza (gmina wiejska nad Luciążą), Sulejów (gmina miejsko-wiejska nad Luciążą i Pilicą), Czarnocin (gmina wiejska nad Wolbórką), Tomaszów Mazowiecki (gmina wiejska nad Pilicą, Wolbórką, Czarną, Piasecznicą), Tomaszów Mazowiecki (miasto nad Pilicą, Wolbórką, Czarną, Piasecznicą), Inowłódz (gmina wiejska nad Pilicą);

3) Bzury - Kutno (miasto nad Ochnią), Łowicz (miasto nad Bzurą) (rycina 1).

Ograniczając proces zasiedlania równin zalewowych, można zminimalizować ryzyko powodziowe, co miałoby wymierne efekty dla ludności oraz samych gmin.

Przedmiotem badań w pracy jest zagospodarowanie terenów zagrożonych powodziami. W opracowaniu zastosowano badania nad użytkowaniem ziemi. 


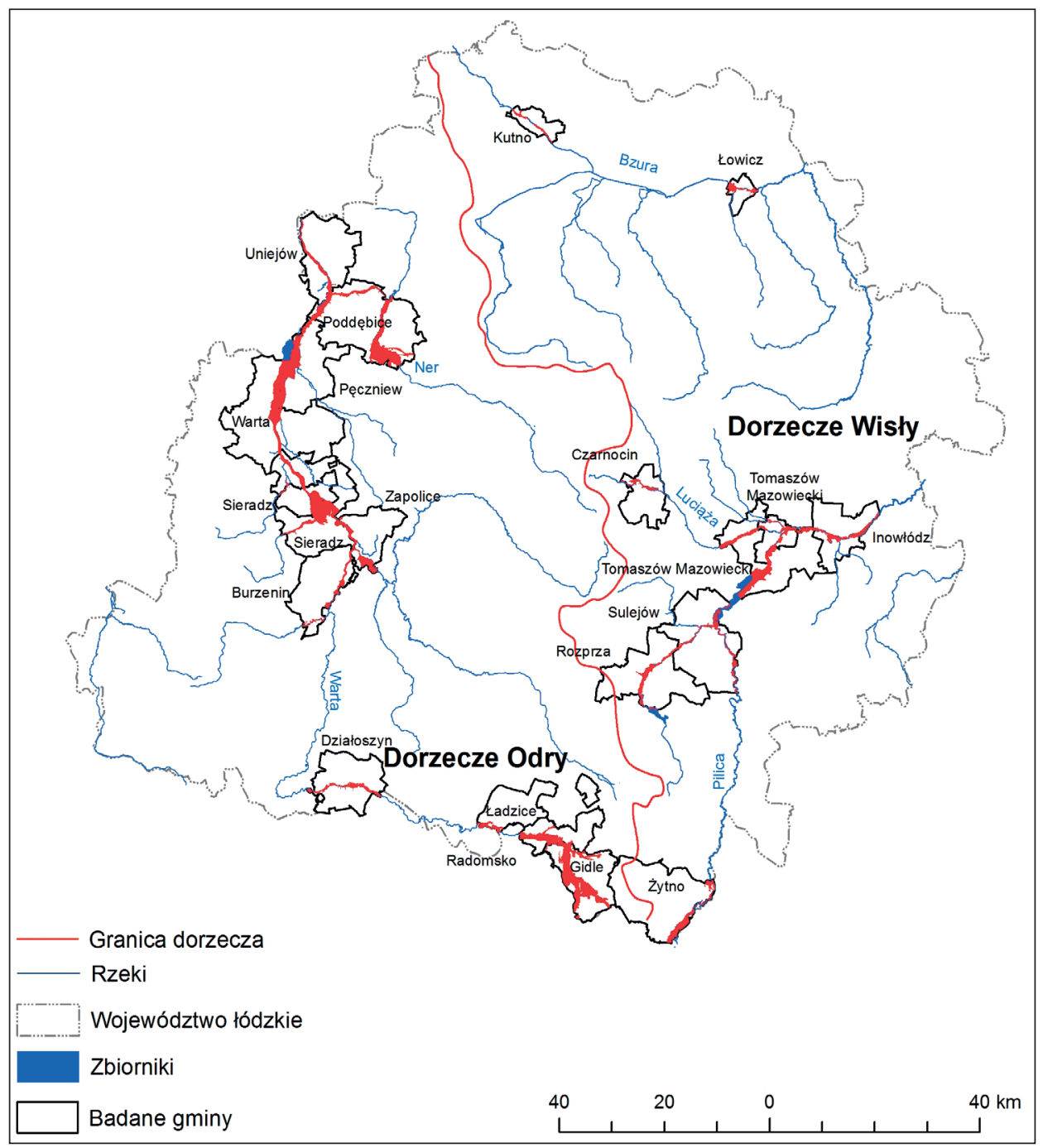

Rycina 1. Tereny zagrożone powodziami w badanych gminach województwa łódzkiego Źródło: opracowanie własne na podstawie danych uzyskanych z Urzędu Wojewódzkiego w Łodzi, 2012

Podmiotem niniejszej pracy są tereny zagrożone powodziami w gminach województwa łódzkiego o dużym i bardzo dużym wskaźniku ryzyka powodziowego (łącznie 21 gmin), które zostały wskazane w Planie operacyjnym ochrony przed powodzią dla województwa tódzkiego z 2013 r. (zastosowana w nim metodologia została opisana w rozdziale 1.1). Obszary zagrożone powodziami to tereny, których zalanie może występować z różnym prawdopodobieństwem (załącznik 21 do Programu bezpieczeństwa powodziowego... 2012, s. 22). W pracy za obszar 
badań przyjęto teren szczególnego zagrożenia powodzią, na którym prawdopodobieństwo wystąpienia powodzi jest średnie i wynosi 1\% (Ustawa z dnia 18 lipca 2001 r. Prawo wodne... 2001).

W ustawie Prawo wodne za tereny narażone na niebezpieczeństwo powodzi rozumie się „określone we wstępnej ocenie ryzyka powodziowego obszary, na których istnieje znaczące ryzyko powodzi lub jest prawdopodobne wystąpienie znaczącego ryzyka powodzi”. Dla tych obszarów wykonano mapy zagrożenia powodziowego. Zaznaczono na nich:

1. Obszary, na których prawdopodobieństwo wystąpienia powodzi jest niskie i wynosi raz na 500 lat lub na których istnieje prawdopodobieństwo wystąpienia zdarzenia ekstremalnego.

2. Obszary szczególnego zagrożenia powodzią, tzn.:

- tereny, na których prawdopodobieństwo wystąpienia powodzi jest średnie i wynosi raz na 100 lat;

- tereny, na których prawdopodobieństwo wystąpienia powodzi jest wysokie i wynosi raz na 10 lat (stanowi to część terenu wody 100-letniej);

- tereny między linią brzegu a wałem przeciwpowodziowym lub naturalnym wysokim brzegiem, w który wbudowano trasę wału przeciwpowodziowego, a także wyspy i przymuliska, o których mowa w art. 18 ustawy Prawo wodne, stanowiące działki ewidencyjne;

- pas techniczny w rozumieniu art. 36 ustawy z 21 marca 1991 r. o obszarach morskich Rzeczypospolitej Polskiej i administracji morskiej.

3. Obszary obejmujące tereny narażone na zalanie w przypadku (tereny potencjalnego zagrożenia):

- przelania się wód przez koronę wału przeciwpowodziowego;

- zniszczenia lub uszkodzenia wału przeciwpowodziowego;

- zniszczenia lub uszkodzenia budowli piętrzących;

- zniszczenia lub uszkodzenia budowli ochronnych pasa technicznego (Ustawa z dnia 18 lipca 2001 r. Prawo wodne... 2001).

Mapy zagrożenia powodziowego z wyznaczonymi granicami terenów narażonych na niebezpieczeństwo powodzi powstały na koniec 2013 r., jednak nie objęły one wszystkich rzek. Przed ich ogłoszeniem za określenie terenów zagrożonych powodziami odpowiadał dyrektor Regionalnego Zarządu Gospodarki Wodnej. Stanowiły one integralną część studium ochrony przeciwpowodziowej. Województwo łódzkie ze względu na swoje położenie, na wododziale I-rzędu pomiędzy dorzeczem Wisły i Odry, podlega Regionalnemu Zarządowi Gospodarki Wodnej w Poznaniu (dorzecze Odry) oraz Warszawie (dorzecze Wisły). Badania rozpoczęto w 2011 r., kiedy nie obowiązywały mapy zagrożenia powodziowego, natomiast w studium ochrony przeciwpowodziowej dla dorzecza Odry, w granicach województwa łódzkiego, nie wyznaczono terenów potencjalnego zagrożenia. Dlatego też autorka zdecydowała się na analizę zagospodarowania, w granicach wody $1 \%$. W pracy nie analizowano zagospodarowania $\mathrm{w}$ obrębie całej 
formy nazywanej równiną zalewową, ale w zasięgu wody $1 \%$, gdyż we wszystkich opracowaniach z zakresu ochrony przeciwpowodziowej wykorzystuje się taki podział. Należy jednak podkreślić, że analizie poddano rzeki nizinne, gdzie przebieg powodzi ma odmienny charakter w stosunku do zlewni wyżynnych i górskich. Równiny zalewowe w dolinach tych rzek są szerokie, w większości podzielone wałami przeciwpowodziowymi, które oddzielają strefę międzywala od doliny w strefie zawala. W strefie zawala często dochodzi do intensywnego zagospodarowania obszarów potencjalnie zagrożonych powodziami (Majda i in. 2012). W wyniku przyjęcia terenu wody $1 \%$ za obszar badań, wykluczono $\mathrm{z}$ analizy równiny zalewowe, położone za wałami.

Autorka w pracy zamiennie stosuje pojęcia terenów: zalewowych, szczególnego zagrożenia powodzią (bezpośredniego zagrożenia), zagrożonych, rozumianych tylko i wyłącznie jako obszary do granicy wody $1 \%$.

W zaproponowanym podejściu zagospodarowanie badane jest $\mathrm{w}$ granicach gmin (nie w granicy zlewni), gdyż to właśnie na poziomie lokalnym istnieją instrumenty planistyczne, dzięki którym możliwe staje się realne kształtowanie przestrzeni. Jest to bardzo istotne z punktu widzenia ochrony przed powodzią.

Empiryczną podstawą analiz był materiał zebrany podczas badań terenowych, przeprowadzonych w latach 2011-2013. Obejmowały one:

- kwerendę w urzędach i instytucjach odpowiedzialnych za ochronę przeciwpowodziową. Pozyskano dane dotyczące: zróżnicowania poziomu ryzyka powodziowego w województwie łódzkim z podziałem na gminy, zasięgu wody 100-letniej, stanu zainwestowania przeciwpowodziowego;

- kwerendę materiałów kartograficznych, umożliwiających studia nad występowaniem powodzi w województwie łódzkim, w ujęciu historycznym oraz charakterystykę dolin rzecznych;

- kwerendę planów i programów dotyczących ochrony przeciwpowodziowej;

- inwentaryzację urbanistyczną, w trakcie której zaktualizowano dane dotyczące zagospodarowania i stworzono dokumentację fotograficzną.

Inwentaryzację terenową przeprowadzono w latach 2012-2013 na obszarze 6 gmin - miasta oraz gminy Tomaszów Mazowiecki, Kutna, Łowicza, Poddębic, Uniejowa, która miała na celu aktualizację podkładów. Podstawę do tych analiz stanowiła Baza Danych Obiektów Topograficznych (BDOT), która, jak stwierdzono, odzwierciedla aktualny stan zagospodarowania. Dlatego też zrezygnowano z badań szczegółowych w pozostałych gminach. W celu analizy aktualnego zagospodarowania na obszarach szczególnego zagrożenia powodzią scalono warstwy pokrycia i użytkowania terenu, pochodzące z Bazy Danych Obiektów Topograficznych. Do kompleksów pokrycia terenu w BDOT zaliczone zostały najważniejsze, powierzchniowe elementy sytuacyjne terenu, rozróżnialne na podstawie ich cech fizjonomicznych. Obiekty należące do tej klasy w sposób kompletny opisują dany obszar. Kompleksy użytkowania terenu to powierzchnie jednorodne 
ze względu na pełnioną funkcję. Do grupy tej zaliczono przede wszystkie obiekty infrastruktury społecznej i gospodarczej. Przekazują one uzupełniające, ale bardzo istotne informacje o użytkowaniu terenu (Wytyczne techniczne TBD... 2008).

W BDOT wydzielono 9 głównych kompleksów pokrycia terenu:

1) obszary wód: wody morskie, wody powierzchniowe płynące, wody powierzchniowe stojące;

2) tereny zabudowy zwartej gęstej lub luźnej: zabudowa blokowa, zabudowa typu śródmiejskiego, zabudowa jednorodzinna, zabudowa przemysłowo-magazynowa, zabudowa inna;

3) tereny leśne lub zadrzewione: las, zagajnik, inne zadrzewienie;

4) tereny roślinności krzewiastej: zarośla krzewów, zarośla kosodrzewiny;

5) tereny upraw trwałych: sad, plantacja, ogródki działkowe;

6) tereny roślinności trawiastej i upraw rolnych: uprawy na gruntach ornych, roślinność trawiasta;

7) tereny pod drogami kołowymi, szynowymi i lotniskowymi: teren pod drogą kołową, teren pod torowiskiem, teren pod drogą kołową i torowiskiem, teren pod drogą lotniskową;

8) tereny gruntów odsłoniętych: teren piaszczysty lub żwirowy, piarg, usypisko, rumowisko skalne, inne grunty odsłonięte;

9) inne tereny niezabudowane: teren pod urządzeniami technicznymi lub budowlanymi, plac z nawierzchnią twardą, teren składowania odpadów, zwałowisko, wyrobisko, dół poeksploatacyjny, inne tereny przemysłowo-składowe, plac bez nawierzchni;

Kompleksy użytkowania terenu zostały podzielone na 11 głównych klas:

1) kompleksy mieszkaniowe: osiedle mieszkaniowe, posesja lub zespół posesji;

2) kompleksy przemysłowo-gospodarcze: zakład produkcyjny, usługowy, remontowy, zakład wydobywczy, elektrownia, elektrociepłownia, gazownia, zakład wodociągowy, ujęcie wody, zakład utylizacji, oczyszczalnia ścieków, wysypisko odpadów, podstacja elektroenergetyczna, przepompownia, gospodarstwo hodowlane;

3) kompleksy handlowo-usługowe: centrum handlowo-usługowe, targowisko, bazar;

4) kompleksy komunikacyjne: lotnisko, port wodny, stacja kolejowa, dworzec autobusowy, stacja metra, stacja paliw, parking, zajezdnia;

5) kompleksy sportowo-rekreacyjne: teren ośrodka sportowo-rekreacyjnego, kompleks domków letniskowych, park, ogród botaniczny, ogród zoologiczny;

6) kompleksy usług hotelarskich i turystycznych: teren hotelu, motelu, teren ośrodka wypoczynkowego, kemping, teren schroniska turystycznego;

7) kompleksy oświatowe: szkoła, zespół szkół, wyższa uczelnia, ośrodek naukowo-doświadczalny, przedszkole; 
8) kompleksy ochrony zdrowia i opieki społecznej: zespół szpitalny, sanatoryjny, zakład opieki specjalnej, dom dziecka;

9) kompleks zabytkowo-historyczny: zespół zamkowy, zespół pałacowy, twierdza, skansen, zespół muzealny, miejsce pamięci narodowej;

10) kompleksy sakralne i cmentarze: zespół sakralny, klasztorny, cmentarz;

11) inny kompleks użytkowania terenu: zakład specjalny, inny kompleks użytkowania terenu.

W wyniku nałożenia na siebie obu warstw otrzymano szczegółowy obraz użytkowania ziemi na obszarach szczególnego zagrożenia powodzią. Dzięki temu możliwe było odpowiednie przyporządkowanie poszczególnych funkcji do określonej grupy w nowo utworzonej klasyfikacji. W celu dokonywania dalszych analiz posłużono się klasyfikacją terenów, wykorzystywaną przy sporządzaniu miejscowych planów zagospodarowania przestrzennego, zgodnie z Rozporzadzeniem Ministra Infrastruktury z 26 sierpnia 2003 r. w sprawie wymaganego zakresu projektu miejscowego planu zagospodarowania przestrzennego (2003). Dodatkową grupę, która została wydzielona, stanowią nieużytki. W konsekwencji wyodrębniono 12 form zagospodarowania, do których przyporządkowano obiekty zbliżone do siebie pod względem sposobu użytkowania. Są to:

1) tereny zabudowy mieszkaniowej - działki ziemi zajęte pod budynki mieszkalne jednorodzinne, wielorodzinne oraz zagrodowe;

2) tereny zabudowy usługowej - wszystkie obszary zajęte przez instytucje, organizacje czy przedsiębiorstwa, służące zaspokajaniu potrzeb ludzi: administracji publicznej, nauki, kultury, służby zdrowia, handlu, gastronomii itp. (Liszewski 1973);

3) tereny użytkowane rolniczo - obszary zajęte pod uprawy oraz ugory, czyli ziemie okresowo niebędące w uprawie oraz łąki i pastwiska;

4) tereny zabudowy techniczno-produkcyjnej - obszary zajęte przez obiekty produkcyjne, składy, magazyny;

5) lasy;

6) tereny zieleni urządzonej - parki, ogrody, zieleń towarzysząca obiektom budowlanym;

7) tereny ogródków działkowych;

8) tereny wód - rzeki, jeziora, stawy, strumienie, kanały;

9) tereny komunikacji - drogi publiczne, torowiska, parkingi, zajezdnie;

10) tereny infrastruktury technicznej - elektroenergetyka, gazownictwo, wodociągi, kanalizacja, telekomunikacja, gospodarowanie odpadami, ciepłownictwo;

11) tereny sportu i rekreacji - ośrodki sportowe, domki letniskowe (Rozporzadzeniem Ministra Infrastruktury... 2003);

12) nieużytki - tereny, które $z$ racji niedogodnych warunków przyrodniczych, bądź też zdewastowane przez człowieka nie nadają się w obecnej postaci do czynnego zagospodarowania, np. wyrobiska (Liszewski 1973). 
W celu oceny zróżnicowania zagospodarowania terenów zagrożonych powodziami w badanych gminach obliczono wskaźnik poziomej intensywności użytkowania, wykorzystania powierzchni oraz terenów wolnych od zabudowy. Intensywność pozioma to miernik odzwierciedlający pokrycie terenu budowlami technicznymi, mierzonymi w płaszczyźnie powierzchni ziemi. Stopień pokrycia terenu świadczy o intensywności przekształceń przestrzeni geograficznej dokonujących się na skutek inwestycyjnej działalności człowieka. Miarą intensywności poziomej użytkowania jest udział procentowy terenów zabudowanych w całości badanego obszaru (Liszewski 1977, s. 87). Ze względu na specyfikę terenu badań, przy obliczaniu wskaźnika poziomej intensywności zagospodarowania nie wzięto pod uwagę terenów komunikacyjnych. Tereny zabudowane generują nie tylko straty materialne, ale również bezpośrednie zagrożenie dla zdrowia, a nawet życia ludzi. Dlatego też osobno obliczono wskaźnik wykorzystania powierzchni, rozumiany jako stopień wykorzystania powierzchni terenu zarówno pod zabudowę, jak i tereny komunikacyjne (Rudnik 2012). Ze względu na wielkość obszarów poddanych analizie i szczegółowość prowadzonych badań, za teren wolny od zabudowy przyjęto powierzchnię niezabudowaną oraz wodę powierzchniową na danym obszarze. Na koniec wydzielono dwie grupy terenów: zabudowanych oraz wolnych od zabudowy, i każdą z nich podzielono na trzy klasy. Za pomocą trójkąta Ossana ${ }^{1}$ określono, jaki typ terenów wolnych od zabudowy oraz zabudowanych dominuje w granicach obszarów zagrożonych powodziami. Następnie w celu klasyfikacji gmin ze względu na strukturę zagospodarowania wykorzystano metodę skupien, która jest narzędziem analizy służącym do grupowania „n” obiektów w „,k” niepustych, rozłącznych oraz możliwie ,jednorodnych” grup skupień. Obiekty należące do danego skupienia powinny być do siebie ,podobne”. Jest to jedna z metod aglomeracyjnych, której idea polega na wyznaczeniu skupień poprzez łączenie powstałych w poprzednich krokach algorytmu, mniejszych skupień (najbardziej do siebie podobnych). W analizie tej wykorzystano odległość euklidesową oraz metodę wiązania skupień Warda. Wyniki przedstawiono w formie dendrogramu, który stanowi graficzną ilustrację przebiegu aglomeracji (Wołyński, Górecki 2013).

Do analizy zarówno struktury użytkowania ziemi na obszarach zagrożonych powodziami, jak i jej oceny wykorzystano narzędzia GiS. Systemy Informacji Przestrzennej służą m.in. do rozwiązywania problemów o charakterze geograficznym, dostarczając narzędzi do wprowadzania, integracji, zarządzania, analizy oraz wizualizacji danych przestrzennych (Ziółkowski i in. 2011).

Kolejny etap polegał na dokonaniu analizy i oceny stanu zainwestowania przeciwpowodziowego w gminach województwa łódzkiego. Na wstępie opisano zasady ich klasyfikacji oraz oceny stanu technicznego. W formie kartograficznej

1 Jest to narzędzie do analizy wielozmiennej, mające zastosowanie jedynie w przypadku tych cech, których wielkości liczbowe można zgrupować w trzy klasy, tworząc tzw. struktury trójdzielne; zarówno tereny zabudowane, jak i wolne od zabudowy podzielono na trzy grupy (Runge 2007). 
przedstawiono wyniki analiz. Porównano je w stosunku do obszaru kraju, co pozwoliło wyciągnąć wnioski.

Na podstawie analizy aktualnego zagospodarowania terenów zagrożonych powodziami w wybranych gminach dokonano autorskiej oceny poziomu ryzyka powodziowego (opis metody został uwzględniony w rozdziale 1.1). Ocena ta wraz z wynikami uzyskanymi z pozostałych rozdziałów doprowadziła do sformułowania wniosków.

Zastosowany w pracy materiał źródłowy można podzielić na literaturę, dokumenty o charakterze strategicznym, ustawy i rozporządzenia, dane zebrane $\mathrm{w}$ trakcie inwentaryzacji terenowej oraz dokumenty udostępnione z instytucji odpowiedzialnych za ochronę przeciwpowodziową. Literaturę wykorzystano przy analizie zagospodarowania, ryzyka powodziowego oraz metod zarządzania nim.

W pracy sięgnięto również do dokumentów o charakterze strategicznym, odnoszących się do polityki wodnej. Opracowania te stanowiły zasobne źródło danych o charakterze diagnostycznym dla określenia aktualnego stanu zagospodarowania oraz przyszłego sposobu zarządzania terenami zalewowymi.

Uzupełnieniem treści dokumentów o charakterze strategicznym były wykorzystane w niniejszej pracy akty prawne o zasięgu krajowym i europejskim, dzięki którym stało się możliwe uporządkowanie i ocena metod ochrony przed powodzią, stosowanych w Polsce. Cennym materiałem okazały się również zapisy ustaw i rozporządzeń, odnoszących się zarówno do problematyki zagospodarowania, planowania przestrzennego, jak i metod ochrony przeciwpowodziowej. $\mathrm{Na}$ ich podstawie możliwe było odniesienie prowadzonych badań do aktualnie obowiązujących przepisów.

Podstawą do realizacji i wizualizacji wykorzystywanych metod badawczych stały się materiały kartograficzne oraz dane zebrane podczas kwerendy w urzędach. W wyniku współpracy z Regionalnymi Zarządami Gospodarki Wodnej w Poznaniu i Warszawie, Wojewódzkim Ośrodkiem Dokumentacji Geodezyjnej i Kartograficznej w Łodzi, Biurem Planowania Przestrzennego Województwa Łódzkiego pozyskano materiały niezbędne do wykonania inwentaryzacji. Udostępnione mapy, prezentujące zasięg wody 100-letniej oraz aktualne pokrycie i użytkowanie terenu, umożliwiły za pomocą narzędzi GIS analizę zagospodarowania, identyfikację kategorii ryzyka powodziowego oraz jego ocenę. Występowały one zarówno w formie wektorowej, jak i rastrowej (wówczas poddano je digitalizacji, a następnie wykorzystano w pracy). Zebrany materiał terenowy, w szczególności w drodze inwentaryzacji urbanistycznej, należy ocenić jako wysoce wiarygodny. Dane dotyczące powodzi historycznych, które uzyskano w Wydziale Bezpieczeństwa i Zarządzania Kryzysowego, jak i w urzędach gmin oraz Instytucie Meteorologii i Gospodarki Wodnej, stanowiły materiał niepełny, który został uzupełniony na podstawie literatury, czasopism naukowych oraz Wstępnej oceny ryzyka powodziowego (2011). 
Zasoby internetowe stanowiły materiał o charakterze uzupełniającym. Korzystano ze stron instytucji odpowiedzialnych za ochronę przeciwpowodziową.

Bardzo cennym materiałem źródłowym, wykorzystanym w pracy, było oprogramowanie udostępniane użytkownikom na zasadach open source. W programie Geospatial Modelling Environment dokonano podziału terenu zagrożonego powodzią w badanych gminach na heksagony, co pozwoliło uniknąć błędu oraz przyspieszyło prowadzenie analiz.

W opinii autorki wykorzystany w pracy materiał źródłowy jest właściwy oraz wystarczający do realizacji założonych celów. 


\section{ZAGOSPODAROWANIE TERENÓW ZALEWOWYCH - WYBRANE ZAGADNIENIA}

\subsection{Problematyka zagospodarowania i oceny ryzyka powodziowego}

Zagospodarowanie przestrzenne to stan przestrzeni, czyli terenów, zabudowy, urządzeń infrastruktury technicznej, społecznej i ekonomicznej, a także środowiska, wynikający z wszelakich działań zmierzających do trwałej zmiany cech fizycznych terenu, czynionych przez człowieka w celu bezpośredniego lub pośredniego zaspokojenia jego potrzeb. Zagospodarowanie polega na wykorzystaniu danego obszaru zgodnie z potrzebami mieszkańców i użytkowników, natomiast celem polityki zagospodarowania jest wyznaczenie, porządkowanie i kontrolowanie zachodzących zmian w przestrzeni (Gorzym-Wilkowski i in. 1999; Regulski 1985). Aktualny stan zagospodarowania bada się na podstawie analizy użytkowania ziemi (Bromek, Mydel 1972). Pod pojęciem użytkowania Liszewski (1997, s. 61) rozumie „używanie czegoś, korzystanie z czegoś w sposób racjonalny, przynoszący jak największy pożytek". W związku z tym prawie każda działalność człowieka ma swoje odbicie w terenie i „pełni ściśle określoną i zróżnicowaną funkcję" (Liszewski 1978, s. 17).

Doliny rzeczne to odrębne układy przyrodnicze charakteryzujące się specyficznymi formami zarówno budowy geologicznej, rzeźby, stosunków wodnych, topoklimatu, jak i fauny oraz flory. To właśnie te cechy środowiska warunkują i kształtują formy gospodarki człowieka. Charakter zagospodarowania dolin ma istotny wpływ na ich walory przyrodnicze, a także ochronę przed powodzią. Na obszarach, gdzie nie rozwija się urbanizacja, stopień przekształcenia komponentów środowiska przyrodniczego wiąże się bezpośrednio z układem typów wykorzystania ziemi. Najwyższy stopień przekształceń $\mathrm{w}$ tym zakresie związany jest z obszarami upraw, niższy z terenami użytków zielonych, natomiast najniższy wykazują obszary leśne. Wszystkie te czynniki prowadzą do postępującej fragmentacji środowiska rzek i dolin. Z punktu widzenia ochrony przed powodzią najistotniejsze znaczenie ma jednak analiza stopnia zainwestowania tych obszarów i wskazanie miejsc szczególnie narażonych na negatywne konsekwencje podczas wystąpienia powodzi, co jest kluczowe w ich właściwej ochronie (Słonecka i in. 2008). Zagospodarowanie ma wpływ na kształtowanie się odpływu, transport fluwialny i transformację fal wezbraniowych. W zlewniach zurbanizowanych, w porównaniu do zlewni leśnych, rolniczych 
i podmiejskich wyraźnie wzrasta rola letnich wezbrań opadowych w kształtowaniu odpływu, a w roztopowych - transportu fluwialnego. Transformacja fal wezbraniowych na terenach zurbanizowanych polega m.in. na skróceniu czasu ich koncentracji i opadania, szybkim wzroście wysokości oraz objętości (Ciupa 2009).

$\mathrm{Z}$ zagospodarowaniem terenów zagrożonych powodziami związane jest pojęcie ryzyka powodziowego (rycina 1.1), które oznacza iloczyn zagrożenia (fizycznych i statystycznych aspektów powodzi), ekspozycji (kto i co jest zagrożone przez powódź) oraz wrażliwości (podatności elementów zagospodarowania na zagrożenie i zdolności do przeciwdziałania oraz likwidacji skutków katastrofy) (Stenchion 1997; Mileti 1999; Merz, Thieken 2004; Apel i in. 2009; Randolph 2004). Współdziałanie tych trzech elementów tworzy tzw. trójkąt ryzyka (Crichton 1999, 2007). Charakter, rodzaj oraz wartość istniejącego stanu zagospodarowania na terenach zagrożonych powodziami decydują o wielkości strat, które mogą wystąpić w postaci uszkodzeń lub zniszczeń obiektów w wyniku zalania (Chojnacki 2000). W literaturze zagranicznej ryzyko jest definiowane jako zagrożenie, wrażliwość, wartość (z obszaru zagrożonego) oraz gotowość (De La Cruz-Reyna 1996). Całkowite ryzyko oznacza oczekiwaną liczbę ofiar śmiertelnych, rannych, szkód materialnych i zakłóceń w działalności gospodarczej, związanych ze zjawiskiem naturalnym (UN DHA 1992; Granger i in. 1999). Najprościej thumacząc, jest to prawdopodobieństwo wystąpienia powodzi i związanych z nią konsekwencji. Mogą one być pożądane bądź niepożądane (Helm 1996; Sayers i in. 2002). Definicje te zostały przyjęte w Dyrektywie Powodziowej (2007, art. 2 pkt 2), zgodnie z którą pojęcie ryzyka powodziowego oznacza „kombinację prawdopodobieństwa wystąpienia powodzi i związanych z nią potencjalnych negatywnych konsekwencji dla zdrowia ludzkiego, środowiska, dziedzictwa kulturowego oraz działalności gospodarczej”.

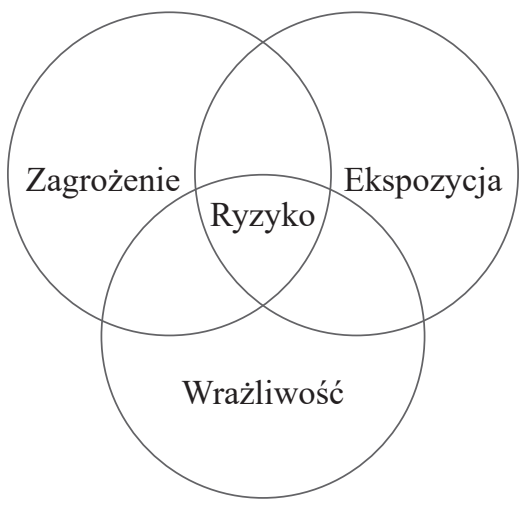

Rycina 1.1. Zależność pomiędzy zagrożeniem a ryzykiem powodziowym Źródło: Randolph (2004, s. 201)

Szkody powstałe na skutek powodzi wynikają z konfliktu pomiędzy przyrodą oraz użytkowaniem terenu przez człowieka. Rodzaj, a także zakres uszkodzeń 
zmienia się stale wraz z rozwojem społeczeństwa (ICPR 2002). Szkody powodziowe (czyli to, co zostało zniszczone lub stracone) odnoszą się do oddziaływania powodzi na ludzi, zwierzęta, roślinność, dziedzictwo kulturowe, infrastrukturę komunalną, produkcję przemysłową (Genovese 2006). Szkody można podzielić na bezpośrednie i pośrednie. Bezpośrednie to takie, które występują w wyniku bezpośredniego oddziaływania wody na ludzi, nieruchomości, środowisko, natomiast do szkód pośrednich należą m.in. zaburzenia ruchu, straty wynikające z ograniczeń produkcji na skutek zniszczonej infrastruktury. Najczęściej oba rodzaje szkód klasyfikuje się bardziej szczegółowo jako dobra materialne i niematerialne, w zależności od tego czy mogą być one oceniane w wartościach pieniężnych (Smith, Ward 1998). Największa część literatury odnoszącej się do szacowania szkód dotyczy bezpośrednich wymiernych strat (Merz, Thieken 2004). Szkody niematerialne nie są uwzględniane, gdyż istnieje przekonanie, że ich udział w całkowitych szkodach jest niewielki (Messner, Meyer 2005). Główną ideą w szacowaniu strat powodziowych jest pojęcie funkcji uszkodzenia lub funkcji strat. Określa ona wrażliwość narażonego majątku na pewne cechy powodzi, głównie na głębokość zalewu (Messner, Meyer 2005). Większość funkcji strat łączy to, że bezpośrednia strata pieniężna jest związana z rodzajem lub użytkowaniem budynku i głębokością zalania (Smith 1981; Krzysztofowicz, Davis 1983; Wind i in. 1999; Green 2003). Najczęściej funkcje uszkodzenia dla budynków są opracowywane na podstawie danych zgromadzonych po powodziach (Thieken i in. 2005). Dane o przewidywanych stratach mogą również być szacowane przez właścicieli obiektów lub specjalistów na podstawie ankietyzacji terenowej. W tym przypadku mogą być analizowane dane statystyczne na temat jednostkowych wartości poszczególnych rodzajów zainwestowania w celu opracowania krzywych strat jednostkowych dla różnych kategorii obiektów. Ogólnie jednak we wszystkich tych metodach dąży się do uzależnienia wartości strat od głębokości zalewu (Chojnacki 2000). Rezultatem większości funkcji strat jest absolutna strata pieniężna dla budynku, niektóre podejścia zapewniają względne funkcje uszkodzenia, straty wówczas podawane są jako procentowa utrata wartości budynku (Dutta $\mathrm{i}$ in. 2003). W przypadku gdy funkcje te są określane do oszacowania straty z tytułu danego scenariusza powodzi, wartości nieruchomości muszą zostać podane z góry (Thieken i in. 2005). Szkody powodziowe zależą od wielu czynników, do których zalicza się: prędkość przepływu, czas trwania powodzi, zanieczyszczenia, poziom wody, informację (ostrzeżenia powodziowe) $i$ in. (Smith 1994; Nicholas i in 2001; Kelman, Spence 2004). Aspekty te są jednak rzadko uwzględniane w modelach strat powodziowych, najczęściej przyjmuje się jedynie głębokość zalewu (Thieken i in 2005). Pomijanie społecznych lub ekonomicznych wskaźników podatności systemu, tj. świadomość zagrożenia czy stopień przygotowania na pojawienie się powodzi, doprowadza do większych strat, co potwierdzają badania niemieckie, według których przygotowanie dolnej kondygnacji domu jednorodzinnego na zalanie obniża szkody o 5-30\%, 
przedział redukcji zależy jednak od głębokości wody (Sowiński 2008, za: Penning-Rowsell $\mathrm{i}$ in. 2003). Podstawowym zadaniem w procesie oceny ryzyka powodziowego jest dokładne poznanie stanu zainwestowania na obszarach zagrożonych (Chojnacki 2000).

W Polsce problematyką zagospodarowania terenów zagrożonych powodziami oraz szacowaniem szkód powstałych na skutek powodzi zajmuje się Zarząd Gospodarki Wodnej (KZGW), Instytut Meteorologii i Gospodarki Wodnej (IMGW), Główny Urząd Geodezji i Kartografii (GUGiK), Rządowe Centrum Bezpieczeństwa (RCB) oraz Instytut Łączności. Stworzono projekt - Informatyczny System Osłony Kraju przed nadzwyczajnymi zagrożeniami, w wyniku którego powstała: wstępna ocena ryzyka powodziowego, mapy zagrożenia i mapy ryzyka powodziowego. Mapy zagrożenia i ryzyka opublikowano na koniec 2013 r., jednak już wcześniej w rozporządzeniu Ministra Środowiska, Ministra Transportu, Budownictwa i Gospodarki Morskiej, Ministra Administracji i Cyfryzacji oraz Ministra Spraw Wewnętrznych z 21 grudnia 2012 r. w sprawie opracowywania map zagrożenia powodziowego oraz map ryzyka powodziowego określono wytyczne, które zostały w nich uwzględnione. Dokumenty te zostały sporządzone zgodnie z postawieniami Dyrektywy Powodziowej, którą Polska musiała przyjąć wraz z członkostwem do UE (http://www.kzgw.gov.p1/Dyrektywa-Powodziowa. html). Głównym celem tego opracowania jest ograniczanie ryzyka powodziowego oraz zmniejszanie następstw powodzi, właściwe zarządzanie ryzykiem, jakie może stwarzać powódź dla zdrowia ludzkiego, środowiska, działalności gospodarczej i dziedzictwa kulturowego, przygotowanie obywateli do radzenia sobie w sytuacji wystąpienia powodzi (Rotnicka 2011). Jest to jedyny dokument, który stanowi wyraźne odniesienie do oceny ryzyka powodziowego w Polsce.

Mapy zagrożenia powodziowego stanowią kolejny po Wstępnej Ocenie Ryzyka Powodziowego (powstała na koniec 2011 r.) etap prac, przewidziany przez tzw. Dyrektywę Powodziową, nad dostosowaniem systemu ochrony przeciwpowodziowej w Polsce do warunków Unii Europejskiej. Powodem stworzenia tych dokumentów planistycznych (ukazały się w grudniu 2013 r.) było poznanie intensywności zjawiska powodzi, a następnie poziomu ryzyka powodziowego, jakie za sobą niesie na konkretnym obszarze. Pojęcie map zagrożenia powodziowego jest nierozerwalnie związane z pojęciem stref zagrożenia powodziowego, które są rozumiane jako obszary przybrzeżne rzek, objęte zalewem powodziowym od strony rzeki, o zasięgu wyznaczonym na podstawie natężenia przepływu, określonego jako miarodajny dla danej strefy (Kitowski, Gromada 2010).

Metodyka opracowania takich map w skali kraju została określa w rozporządzeniu Ministra Środowiska, Ministra Infrastruktury oraz Ministra Spraw Wewnętrznych i Administracji z 21 grudnia 2012 r. Wykonano je dla każdego z obszarów zagrożenia powodziowego, które zostały wyznaczane na podstawie rzędnych zwierciadła wody, uzyskanych w wyniku matematycznego modelowania hydraulicznego, przy wykorzystaniu systemów informacji przestrzennej (GIS), bazując 
na numerycznym modelu terenu. Omawiane obszary zagrożenia powodziowego prezentowane są jako obiekty powierzchniowe, z przyporządkowaną wartością prawdopodobieństwa wystąpienia powodzi (Kurczyński 2012). Na mapach zagrożenia powodziowego przedstawiono:

1. Obszary, na których prawdopodobieństwo wystąpienia powodzi jest niskie i wynosi raz na 500 lat lub, takie, na których występuje prawdopodobieństwo pojawienia się zdarzenia ekstremalnego.

2. Obszary szczególnego zagrożenia powodzią (wcześniej definiowane jako obszary bezpośredniego zagrożenia powodzią).

3. Obszary obejmujące tereny narażone na zalanie w przypadku:

- przelania się wód przez koronę wału przeciwpowodziowego;

- zniszczenia lub uszkodzenia wału przeciwpowodziowego;

- zniszczenia lub uszkodzenia budowli piętrzących;

- zniszczenia lub uszkodzenia budowli ochronnych pasa technicznego.

Dla omawianych obszarów na mapach zagrożenia powodziowego zaprezentowano:

- zasięg powodzi;

- głębokość wody lub poziom zwierciadła wody;

- prędkość przepływu wody lub natężenie przepływu wody - w uzasadnionych przypadkach (Ustawa z dnia 18 lipca 2001 r. Prawo wodne... 2001).

Omawiane mapy przygotowano w dwóch zestawach tematycznych:

- mapę zagrożenia powodziowego wraz z głębokością wody;

- mapę zagrożenia powodziowego wraz z prędkościami oraz kierunkami przepływu wody.

Rozporządzenie w sprawie opracowywania map zagrożenia i map ryzyka powodziowego z 2012 r. określa dokładnie głębokości wody, które musiały zostać uwzględnione:

- poniżej $0,5 \mathrm{~m}$, wskazujący na niskie zagrożenie dla ludzi i obiektów budowlanych;

- od 0,5 do $2 \mathrm{~m}$, wskazujący na średnie zagrożenie dla ludzi, ale wysokie ze względu na straty materialne;

- od 2 do $4 \mathrm{~m}$, wskazujący na wysokie zagrożenie dla ludzi;

- > 4 m, wskazujący na bardzo wysokie zagrożenie dla ludzi i ekstremalnie wysokie zagrożenie wystąpienia szkód całkowitych.

Przedziały głębokości określono ze względu na zagrożenie ludzi i potrzeby ewentualnego opracowania planów ewakuacyjnych. Kryteria, które zostały wyznaczone dla map zagrożenia powodziowego, są powszechnie używane w krajach UE - Holandii, Francji, Niemczech oraz Szwajcarii (Kurczyński 2012).

Mapy ryzyka powodziowego sporządza się dla obszarów zagrożonych powodziami (art. 88d ust. 2 ustawy Prawo wodne). Przedstawiają one potencjalne negatywne skutki związane z powodzią. Zostały one przygotowane (na koniec grudnia 2013 r.) w podziale na dwa zestawy tematyczne: 
1) mapy ryzyka powodziowego przedstawiające zagrożenie dla ludności oraz potencjalne straty powodziowe;

2) mapy ryzyka powodziowego przedstawiające użytkowanie terenu oraz obszary i obiekty o szczególnym znaczeniu kulturowym, przyrodniczym, gospodarczym.

Ryzyko powodziowe wyrażono poprzez określenie zmiennych społeczno-ekonomicznych, $\mathrm{tj}$.:

- szacunkową liczbę mieszkańców potencjalnie dotkniętych powodzią, określaną na podstawie liczby osób zameldowanych;

- budynki mieszkalne;

- wartości potencjalnych strat powodziowych;

- obiekty o szczególnym znaczeniu społecznym;

- obszary i obiekty o szczególnym znaczeniu kulturowym, przyrodniczym i gospodarczym;

- klasy użytkowania terenu (Rozporządzenie Ministra Środowiska... 2013).

Mapy ryzyka powodziowego przedstawiają również wartości strat powodziowych wyznaczonych dla 8 klas użytkowania terenu:

1) terenów zabudowy mieszkaniowej;

2) terenów przemysłowych;

3) komunikacji;

4) lasów;

5) terenów rekreacyjno-wypoczynkowych;

6) użytków rolnych;

7) wód;

8) pozostałych.

Ponadto na omawianych mapach znajdują się budynki mieszkalne oraz o znaczeniu społecznym, dla których określono średnie głębokości wody. Dzięki temu można oszacować stopień zagrożenia ludności według następujących klas:

- głębokość wody $<2 \mathrm{~m}$ (niskie i średnie zagrożenie dla ludzi);

- głębokość wody $>2$ m (wysokie i bardzo wysokie zagrożenie dla ludzi).

Rozporządzenie w sprawie opracowywania map zagrożenia i map ryzyka powodziowego jasno określa sposób obliczania wartości potencjalnych strat powodziowych, w poszczególnych klasach użytkowania terenu. Podstawą do ich szacowania była metodyka stosowana w Niemczech. Wykorzystano w niej funkcję strat, która zależy od głębokości wody oraz rodzaju użytkowania terenu.

Mapy ryzyka powodziowego stanowią niezwykle cenne źródło informacji o stanie zagospodarowania przestrzennego terenów zagrożonych powodziami. Jest to jedyne opracowanie, które w sposób kompleksowy ujmuje tą tematykę. Zawierają one dane o szacunkowych stratach, a także o zagrożonych obiektach w postaci przestrzennej bazy danych GIS. Zabrakło na nich jednak zróżnicowania poziomu tego ryzyka, aby było ono porównywalne pomiędzy różnymi odcinkami rzek. Ułatwiłoby to znacząco prowadzenie odpowiedniej polityki w zakresie ochrony przeciwpowodziowej. 
Przed ukazaniem się map zagrożenia i ryzyka powodziowego istniały próby oceny ryzyka powodziowego. Charakterystyka ryzyka ${ }^{1}$, według Chojnackiego (2000), obejmowała zbiór informacji o mogących wystąpić uszkodzeniach i zniszczeniach obiektów zagospodarowania na danym obszarze. Informacje te zawierały określenie rodzaju i lokalizacji przestrzennej obiektów, wielkości szkód i strat powodziowych oraz wartości zainwestowania obszaru. W tym celu dokonano:

- określenia wielkości przewidywanej szkody powodziowej - ustalenie liczby poszczególnych obiektów znajdujących się na obszarze zagrożonym;

- określenia wielkości przewidywanej straty powodziowej - wartościowa wycena potencjalnych przeciętnych uszkodzeń lub zniszczeń na danym terenie (w jednostkach pieniężnych);

- określenia wartości zainwestowania - wartościowe oszacowanie wielkości zainwestowania poszczególnych rodzajów obiektów na danym obszarze (w jednostkach pieniężnych).

$\mathrm{W}$ tej metodologii założono, że ocena stanu zainwestowania powinna obejmować następujące obiekty zlokalizowane na obszarze zagrożonym:

- grunty orne w (ha);

- użytki zielone (ha);

- wały $(\mathrm{km})$;

- brzegi uregulowane $(\mathrm{km})$,

- budynki (szt.);

- drogi krajowe $(\mathrm{km})$;

- mosty na drogach krajowych (szt.);

- drogi krajowe $(\mathrm{km})$;

- mosty na drogach krajowych (szt.);

- drogi lokalne $(\mathrm{km})$;

- mosty na drogach lokalnych (szt.);

- szlaki kolejowe $(\mathrm{km})$;

- mosty kolejowe (szt.).

Zgodnie z przyjętym modelem, wartości przewidywanych strat powodziowych były szacowane w danej grupie obiektów jako iloczyn ich liczby oraz ustalonych wartości wskaźnika strat jednostkowych. Określone na tej podstawie wartości potencjalnych strat powiększano o $25 \% \mathrm{w}$ celu uwzględnienia pozostałych strat, które nie zostały ujęte. Jednak ze względu na to, że wówczas ogromne trudności sprawiała ocena zagospodarowania terenów zagrożonych powodziami na obszarach miejskich, w szczególności ocena ilościowa: terenów zielonych, budynków oraz ulic, zaproponowano metodę typizacji zagospodarowania obszarów zagrożonych. W metodzie tej wykorzystano wskaźniki strat jednostkowych na 1 ha, które zostały określone dla założonych, charakterystycznych typów

1 Wówczas określona mianem zagrożenia powodziowego. 
zagospodarowania obszaru miejskiego. W rozwiązaniu zaproponowano kilka rodzajów typowego zagospodarowania dla założonego obszaru $1 \mathrm{~km}^{2}$. Szacowanie strat tą metodą obejmowało trzy zasadnicze, a trudne do bezpośredniej wyceny elementy zagospodarowania: ulice, budynki i tereny zielone. Założono następujące typy zagospodarowania:

- typ A - tereny zielone (100\%);

- typ B - tereny zielone (80\%) + rzadka sieć komunikacyjna (do $5 \mathrm{~km}$ ulic) + bardzo rzadka zabudowa (50 bud.);

- typ C - tereny zielone (50\%) + rzadka sieć komunikacyjna (do $5 \mathrm{~km}$ ulic) + rzadka zabudowa (100 bud.);

- typ D - tereny zielone (30\%) + gęsta sieć komunikacyjna (do $10 \mathrm{~km}$ ulic) + gęsta zabudowa (200 bud.);

- typ E - tereny zielone (10\%) + bardzo gęsta sieć komunikacyjna (do $15 \mathrm{~km}$ ulic) + bardzo gęsta zabudowa (300 bud.).

Dla ww. typizacji obszarów miejskich oszacowano wartości strat obszarowych na podstawie aktualnych wskaźników strat jednostkowych, które w efekcie dały miarodajny wskaźnik strat obszarowych na 1 ha. Do wartości sumowanych strat dla terenów zurbanizowanych doliczano $25 \%$ narzutu dla uwzględnienia potencjalnych strat w zakresie innych obiektów niemożliwych do oceny. Zaproponowane rozwiązanie, choć uproszczone, to jednak w ówczesnym czasie spełniało oczekiwany poziom dokładności szacowania strat, z uwagi na brak odpowiednich materiałów źródłowych (Chojnacki 2000).

Obecnie problem ten został rozwiązany poprzez stworzenie Bazy Danych Obiektów Topograficznych oraz map zagrożenia i ryzyka powodziowego.

Pierwszą próbę oceny poziomu ryzyka powodziowego na obszarze województwa łódzkiego podjął Wydział Bezpieczeństwa i Zarządzania Kryzysowego Urzędu Wojewódzkiego w Łodzi. Analiza ta opierała się na informacjach przesłanych na przełomie stycznia i lutego 2012 r. z jednostek samorządu terytorialnego oraz danych będących w posiadaniu Oddziału Zarządzania Kryzysowego Łódzkiego Urzędu Wojewódzkiego w Łodzi, a także funkcjonującego w strukturach tego Oddziału - Wojewódzkiego Centrum Zarządzania Kryzysowego. W zastosowanej metodzie ryzyko powodziowe zostało sklasyfikowane za pomocą pięciu stopni, od minimalnego do bardzo dużego (minimalne, małe, średnie, duże i bardzo duże). Poszczególne stopnie wyliczono za pomocą arkusza kalkulacyjnego (tabela 1.1), w ramach którego uwzględniono 9 różnych czynników, obrazujących sytuację powodziową na obszarze jednostki samorządowej. W ramach każdego czynnika możliwe było określenie natężenia występowania danego zjawiska: od poziomu marginalnego do istotnego z punktu widzenia bezpieczeństwa powodziowego danego samorządu. 


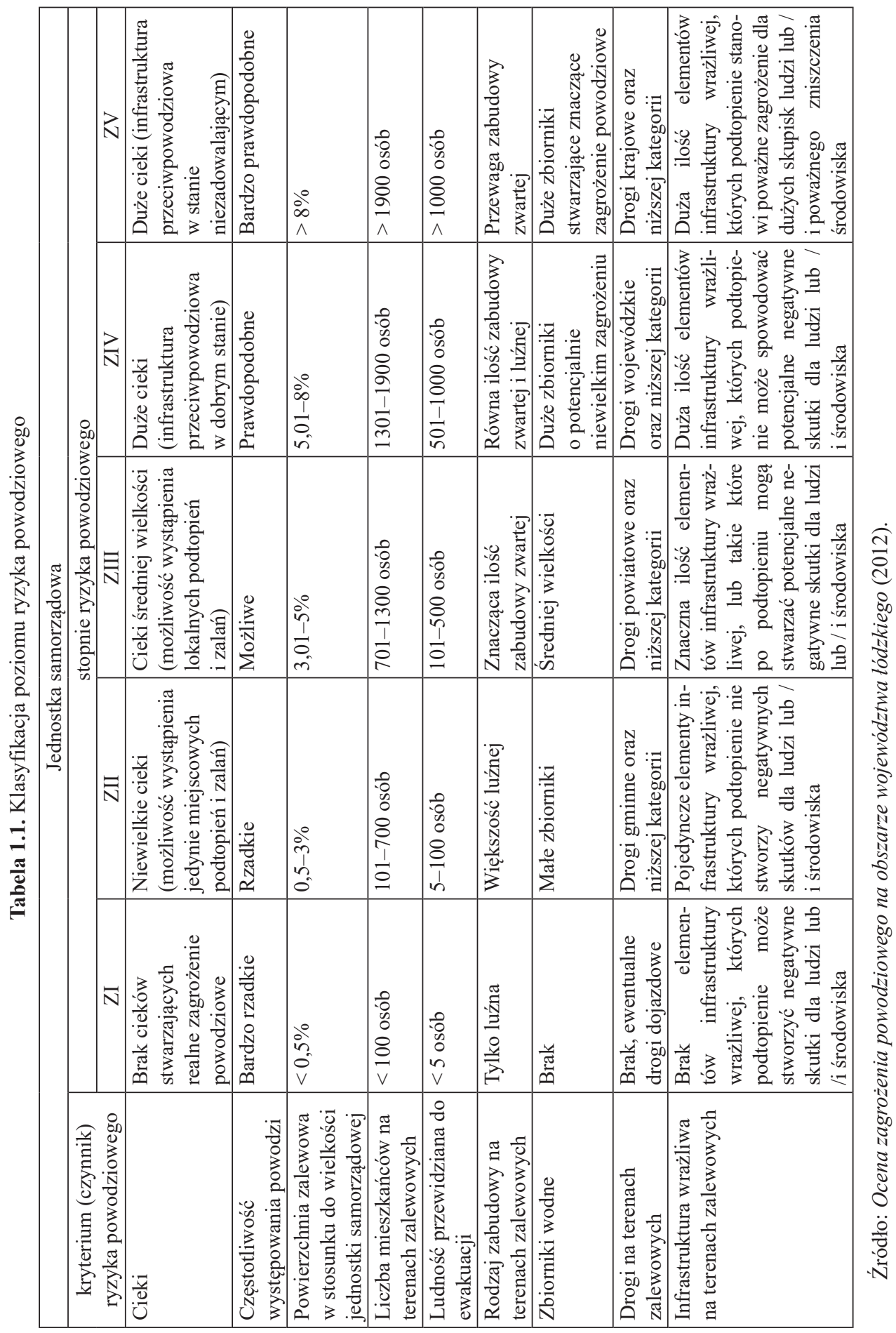


Na podstawie arkusza określono poziom ryzyka powodziowego danej gminy w formie jednego (wypadkowego) parametru (HG), zgodnie z następującą zależnością:

$$
H G=\sum_{i=I} \frac{n i}{L b i},
$$

gdzie:

$H G$ - wypadkowy wskaźnik ryzyka powodziowego gminy;

$n i$ - liczba kryteriów (czynników) zagrożenia, które zostały zakwalifikowane do i-tego stopnia ryzyka;

LBi - liczba bazowa (waga) dla i-tego stopnia ryzyka (Ocena zagrożenia ... 2012).

Przedstawiona zależność opiera się na obliczeniu średniej ważonej ze wszystkich czynników ryzyka ujętych w arkuszu kalkulacyjnym. Waga danego czynnika wzrasta proporcjonalnie w zależności od stopnia, do którego został zakwalifikowany. Wartości liczby bazowej dla poszczególnych stopni ryzyka powodziowego zostały przedstawione w tabeli 1.2.

Tabela 1.2. Wartości liczby bazowej dla poszczególnych stopni ryzyka powodziowego

\begin{tabular}{|c|c|}
\hline Stopień ryzyka powodziowego gminy & Wartość liczby bazowej LBi \\
\hline ZIG & L BI $=5$ \\
\hline ZIIG & L BII $=4$ \\
\hline ZIIIG & L BIII $=3$ \\
\hline ZIVG & L BIV $=2$ \\
\hline ZVG & L BV $=1$ \\
\hline
\end{tabular}

Źródło: Ocena zagrożenia... (2012).

Tabela 1.3. Stopnie ryzyka powodziowego dla gmin województwa łódzkiego

\begin{tabular}{|c|c|c|}
\hline $\begin{array}{c}\text { Stopień ryzyka powodziowego } \\
\text { gminy }\end{array}$ & $\begin{array}{c}\text { Przedziały wartości wskaźnika } \\
\text { ryzyka powodziowego gminy HG }\end{array}$ & Ryzyko powodziowe \\
\hline ZIG & $1,8-2,03$ & Minimalne \\
\hline ZIIG & $2,04-2,64$ & Małe \\
\hline ZIIIG & $2,65-3,76$ & Średnie \\
\hline ZIVG & $3,77-6,77$ & Duże \\
\hline ZVG & $6,78-9,0$ & Bardzo duże \\
\hline
\end{tabular}

Źródło: Ocena zagrożenia... (2012).

Po obliczeniu omawianego parametru ustalono stopień ryzyka powodziowego gminy, od poziomu minimalnego do bardzo dużego (do pracy wybrano 21 gmin o bardzo dużym i dużym ryzyku powodziowym). Dokonano tego poprzez porównanie obliczonej wartości wskaźnika ryzyka z danymi przedstawionymi w tabeli 1.3. 


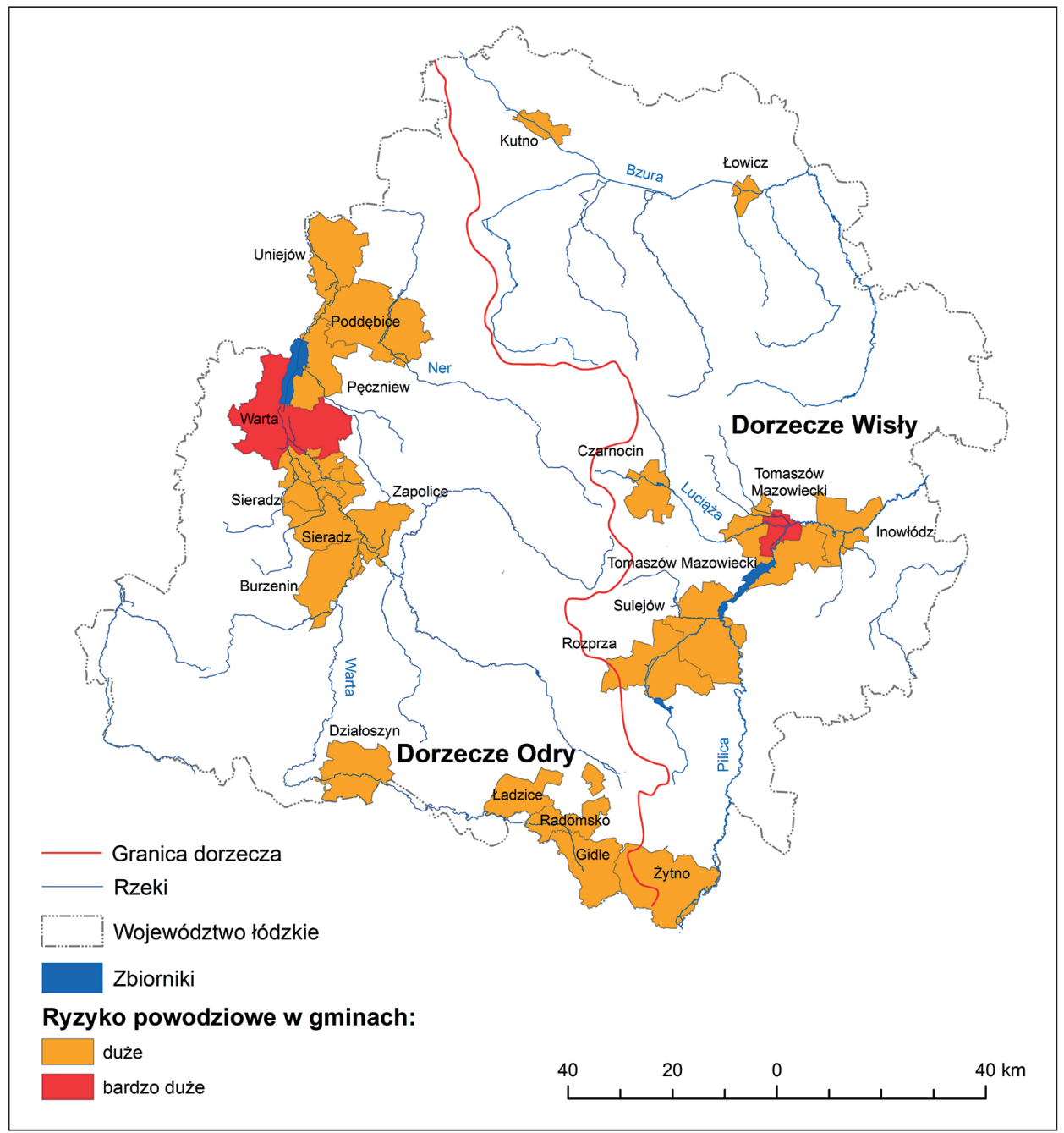

Rycina 1.2. Gminy o dużym i bardzo dużym poziomie ryzyka powodziowego w województwie łódzkim Źródło: opracowanie własne na podstawie Oceny zagrożenia... (2012)

Wyniki przeprowadzonej analizy wskazały, że na 149 gmin z obszaru województwa łódzkiego w dwóch (Warcie i Tomaszowie Mazowieckim) ryzyko powodziowe jest bardzo duże, a w 19 duże (rycina 1.2).

W związku z brakiem jednej skutecznej oceny poziomu ryzyka powodziowego, autorka zaproponowała własną metodologię wyznaczania jego poziomu. $\mathrm{Na}$ podstawie analizy aktualnego zagospodarowania terenów zagrożonych powodziami w wybranych gminach dokonano identyfikacji obiektów i terenów, generujących potencjalne negatywne konsekwencje w trakcie wystąpienia powodzi. 
Ze względu na duże zróżnicowanie obiektów oraz terenów w granicach wody $1 \%$ wydzielono cztery kategorie ryzyka powodziowego:

- obiekty społeczne, gdzie na stałe lub czasowo może przebywać duża liczba osób;

- obiekty dziedzictwa kulturowego i tereny cenne przyrodniczo;

- obiekty potencjalnie zagrażające środowisku przyrodniczemu oraz ludziom;

- tereny generujące straty ekonomiczne.

\section{Kategorie ryzyka powodziowego}

W grupie obiektów społecznych znalazły się następujące budynki:

- mieszkaniowe (zarówno jedno-, jak i wielorodzinne);

- szpitale;

- szkoły;

- przedszkola;

- hotele;

- sanatoria.

Do kategorii obszarów wartościowych przyrodniczo oraz dziedzictwa kulturowego zaliczono:

- obszary Natura 2000;

- rezerwaty przyrody;

- parki krajobrazowe;

- ogrody zoologiczne;

- obszary i obiekty zabytków nieruchomych, w szczególności objętych formami ochrony zabytków, o których mowa w art. 7 pkt 1 Ustawy z dnia 23 lipca 2003 r. o ochronie zabytków i opiece nad zabytkami (2003);

- zabytki wpisane na Listę dziedzictwa światowego, o której mowa w art. 11 ust. 2 Konwencji w sprawie ochrony światowego dziedzictwa kulturalnego i naturalnego, przyjętej w Paryżu dnia 16 listopada 1972 r. przez Konferencję Generalna Organizacji Narodów Zjednoczonych dla Wychowania, Nauki i Kultury na jej siedemnastej sesji (1976);

- skanseny i muzea wpisane do Państwowego Rejestru Muzeów, o których mowa w art.13 Ustawy z dnia 21 listopada 1996 r. o muzeach (2012).

W grupie obiektów, które potencjalnie mogą zagrażać zarówno ludziom, jak i środowisku przyrodniczemu w przypadku wystąpienia powodzi, znalazły się:

- oczyszczalnie ścieków;

- przepompownie;

- składowiska odpadów;

- zakłady przemysłowe, w tym: instalacje lub zespoły instalacji, na których prowadzenie jest wymagane uzyskanie pozwolenia zintegrowanego $\mathrm{w}$ rozumieniu art. 181 ust. 1 pkt 1 Ustawy z dnia 27 kwietnia 2001 r. - Prawo ochrony środowiska (2008), w następujących kategoriach działalności przemysłowej: przemysł energetyczny, produkcja i obróbka metali, przemysł mineralny, przemysł chemiczny, gospodarka odpadami, inne rodzaje działalności obejmujące: produkcję 
i przetwórstwo papieru oraz drewna, intensywny chów lub hodowlę drobiu i świń, produkcję i przetwarzanie surowców roślinnych i zwierzęcych;

- zakłady przemysłowe niewymagające pozwolenia, o którym mowa w pkt 1 , a które mogą stwarzać zagrożenie, w tym zakłady o dużym ryzyku wystąpienia awarii albo zwiększonym ryzyku wystąpienia awarii, w rozumieniu art. 248 ust. 1 Ustawy z dnia 27 kwietnia 2001 r. - Prawo ochrony środowiska (2008).

Wyceny strat materialnych dokonano przy użyciu Bazy Danych Obiektów Topograficznych (BDOT). Zgodnie z rozporządzeniem Ministra Środowiska, Ministra Transportu, Budownictwa i Gospodarki Morskiej, Ministra Administracji i Cyfryzacji oraz Ministra Spraw Wewnętrznych z 21 grudnia 2012 r. w sprawie opracowywania map zagrożenia powodziowego oraz map ryzyka powodziowego w celu określenia potencjalnych strat majątku na obszarach zagrożonych powodziami, należy wydzielić następujące obszary użytkowania terenu:

1) osiedla mieszkaniowe;

2) tereny działalności gospodarczych;

3) tereny komunikacyjne;

4) lasy;

5) tereny rekreacyjno-wypoczynkowe;

6) użytki rolne;

7) wody;

8) pozostałe obszary, dla których nie są określane straty powodziowe.

Ocena ryzyka powodziowego związana jest z oceną wielkości szkód wszystkich kategorii dla poszczególnych scenariuszy powodziowych w układzie przestrzennym, a jej efektywność w dużej mierze uzależniona jest od dostępnych danych topograficznych (Nachlik 2011).

We wszystkich wydzielonych kategoriach ryzyka powodziowego dokonano jego oceny, od poziomu minimalnego (1) do bardzo dużego (5), gdzie polem podstawowym był heksagon o powierzchni $0,5 \mathrm{ha}^{2}$. Poziom ryzyka określono przy założeniu, że głębokość zalania wyniesie od 0,5 do $2 \mathrm{~m}$. Następnie stworzono mapę, na której znalazła się syntetyczna ocena poziomu ryzyka powodziowego na badanych obszarach, dzięki której możliwe jest odpowiednie zarządzanie ryzykiem.

W grupie obiektów społecznych, dziedzictwa kulturowego i terenów cennych przyrodniczo, a także obiektów potencjalnie zagrażających środowisku przyrodniczemu oraz ludziom, przy ocenie poziomu ryzyka powodziowego brano pod uwagę powierzchnię, jaką one zajmują w każdym heksagonie ${ }^{3}$. Obszar heksagonu ( $0,5 \mathrm{ha}$ ) podzielono na 5 równych klas (co $0,1 \mathrm{ha})$, im większa powierzchnia

2 Tereny zagrożone powodzią we wszystkich badanych gminach podzielono w programie Geospatial Modelling Environment na heksagony o powierzchni 0,5 ha. Wielkość heksagonu została dopasowana w taki sposób, by jak najwięcej pełnych figur zmieściło się w granicach analizowanego terenu.

3 Oceny poziomu ryzyka powodziowego dokonano przy założeniu, że głębokość zalania wynosi od 0,5 do $2 \mathrm{~m}$. Wynikało to ze specyfiki powodzi na obszarze województwa łódzkiego. 
w obrębie heksagonu, zajęta przez budynki lub tereny przypisane do danej kategorii ryzyka powodziowego, tym wyższy jego poziom. Jeśli obiekty lub obszary zajmowały powierzchnię w heksagonie do $1000 \mathrm{~m}^{2}$ (jednak więcej niż 0), otrzymywały poziom ryzyka minimalny (1), 1001-2000 $\mathrm{m}^{2}$, poziom ryzyka mały (2), 2001-3000 $\mathrm{m}^{2}$, poziom ryzyka średni (3), 3001-4000 $\mathrm{m}^{2}$, poziom ryzyka duży (4), > $4000 \mathrm{~m}^{2}$, poziom ryzyka bardzo duży (5).

Oceny strat ekonomicznych dokonano, analizując 7 wydzielonych obszarów użytkowania ziemi w każdym heksagonie. Wartość strat jednostkowych dla terenów mieszkaniowych, terenów działalności gospodarczych oraz komunikacyjnych ściśle związana jest z głębokością wody, a tym samym ze stopniem utraty wartości majątku (tabela 1.4).

Tabela 1.4. Stopień utraty majątku ze względu na funkcję oraz głębokość wody

\begin{tabular}{|l|c|}
\hline \multicolumn{1}{|c|}{ Klasa użytkowania terenu } & $\begin{array}{c}\text { Wartość funkcji strat } \mathrm{f}(\mathrm{h})[\%] \mathrm{w} \text { przedziale głębokości } \\
\text { od } 0,5<\mathrm{h} \leq 2 \mathrm{~m}\end{array}$ \\
\hline Tereny zabudowy mieszkaniowej & 35 \\
\hline Tereny działalności gospodarczych & 40 \\
\hline Tereny komunikacyjne & 10 \\
\hline
\end{tabular}

Źródło: Rozporzadzenie Ministra Środowiska, Ministra Transportu... (2013).

Potencjalną wartość strat ekonomicznych określono dla głębokości wody w przedziale od 0,5 do $2 \mathrm{~m}$. Dopiero łącznie trzy elementy: użytkowanie terenu, głębokość wody oraz wartość majątku (która dla terenów mieszkaniowych oraz działalności gospodarczych jest zróżnicowana według województw) służą do szacowania potencjalnych strat liczonych w pieniądzu (tabela 1.5).

Tabela 1.5. Wartość utraty majątku w województwie łódzkim ze względu na klasy użytkowania terenu

\begin{tabular}{|l|c|}
\hline \multicolumn{1}{|c|}{ Klasa użytkowania terenu } & $\begin{array}{c}\text { Wartość majątku w przedziale głębokości } \\
\text { Od } 0,5<\mathrm{h} \leq 2 \mathrm{~m}\end{array}$ \\
\hline Tereny zabudowy mieszkaniowej & $101,83 \mathrm{zt} / \mathrm{m}^{2}$ \\
\hline Tereny działalności gospodarczych & $331,68 \mathrm{zz} / \mathrm{m}^{2}$ \\
\hline Tereny komunikacyjne & $43,6 \mathrm{zt} / \mathrm{m}^{2}$ \\
\hline Lasy & $80 \mathrm{zt} / \mathrm{ha}$ \\
\hline Tereny rekreacyjno-wypoczynkowe & $5,1 \mathrm{zt} / \mathrm{m}^{2}$ \\
\hline Grunty orne & $1428 \mathrm{zt} / \mathrm{ha}$ \\
\hline Użytki zielone & $674 \mathrm{zt} / \mathrm{ha}$ \\
\hline
\end{tabular}

Źródło: Rozporządzenie Ministra Środowiska, Ministra Transportu... (2013).

Sposób dokonywania wyceny majątku zaproponowany w rozporządzeniu z 21 grudnia 2012 r. w sprawie opracowywania map zagrożenia powodziowego 
oraz map ryzyka powodziowego, został oparty o metodologię stosowaną w Niemczech (Drożdżal i in. 2009). Należy jednak pamiętać, że z powodu zmienności cen należy dane te aktualizować, by zachować porównywalność wielkości szkód i strat (Chojnacki 1994).

Przy ocenie ryzyka związanego z potencjalnymi stratami ekonomicznymi zliczona została powierzchnia zajmowana przez wyodrębnione klasy użytkowania terenu w każdym heksagonie. Następnie obliczono dla każdej z nich wartość majątku, którą zsumowano w obrębie pola podstawowego (heksagonu). Za maksymalny poziom ryzyka przyjęto wartość strat dla terenów działalności gospodarczych. Maksymalna wielkość strat w heksagonie wynosiła 1658,4 tys. zł. Utworzono pięć równych przedziałów wartości majątku (co 331,68 tys. zł) i dla każdego z nich określono poziom ryzyka, od minimalnego do bardzo dużego, uzyskując obraz wielkości ryzyka powodziowego ze względu na straty ekonomiczne.

W celu zróżnicowania gmin według poziomu ryzyka powodziowego przeanalizowano udział heksagonów o określonym stopniu ryzyka, w granicach wody 100-letniej, w każdej wyodrębnionej kategorii. Pod uwagę brano jedynie heksagony o powierzchni powyżej 0,4 ha, gdyż tylko w ich granicach możliwe było uzyskanie najwyższego poziomu ryzyka powodziowego. $Z$ dalszej analizy wyeliminowano te heksagony, których powierzchnia była mniejsza. Następnie stworzono ranking gmin, w każdej kategorii ryzyka powodziowego, według wzoru:

$$
P=\frac{\sum U^{*} R_{\mathrm{i}-\mathrm{go}}}{5}
$$

gdzie:

$P$ - poziom ryzyka w danej kategorii;

$U$ - udział heksagonów o określonym poziomie ryzyka powodziowego $\mathrm{w}$ danej kategorii, w powierzchni terenu wody 100-letniej danej gminy;

$R_{\mathrm{i}-\mathrm{go}}$ - stopień ryzyka w określonej kategorii;

5 - liczba poziomów ryzyka ${ }^{4}$.

W wyniku tych obliczeń uzyskano wartości dla wszystkich gmin, w każdej kategorii ryzyka powodziowego, które uszeregowano malejąco zgodnie z uzyskanymi wielkościami i na tej podstawie stworzono ranking gmin według jego poziomu.

$\mathrm{Na}$ koniec dokonano oceny syntetycznego poziomu ryzyka powodziowego w badanych gminach województwa łódzkiego. W pierwszej kolejności przeanalizowano poziom ryzyka w każdym heksagonie, we wszystkich wyodrębnionych kategoriach, ze względu na powierzchnię przez nie zajmowaną. Na ogólny poziom ryzyka decydujący wpływ miała najwyższa wartość uzyskana w danym heksagonie (przynajmniej w jednej wyodrębnionej kategorii) (tabela 1.6).

${ }^{4}$ Ryzyko powodziowe w danej kategorii rośnie wraz ze wzrostem udziału heksagonów o najwyższym poziomie tego ryzyka. Wzór został opracowany przez autorkę. 
Następnie przeanalizowano również syntetyczny poziom ryzyka powodziowego w gminach, ze względu na zróżnicowanie obiektów i terenów przypisanych do poszczególnych kategorii, na terenach zalewowych. W tej klasyfikacji brano pod uwagę miejsce danej gminy według poziomu ryzyka powodziowego w każdej jego kategorii. Pozycja gminy oznaczała liczbę punktów, im mniej, tym wyższy poziom ryzyka ogółem (wyniki zaprezentowano w rozdziale 5).

Tabela 1.6. Kryteria oceny syntetycznego poziomu ryzyka powodziowego w heksagonie

\begin{tabular}{|l|l|}
\hline $\begin{array}{c}\text { Poziom ryzyka } \\
\text { powodziowego }\end{array}$ & \multicolumn{1}{|c|}{ Kryteria } \\
\hline Minimalny & 1 lub 2 klasy uzyskały wartość 1 \\
\hline Mały & 1 lub 2 klasy uzyskały wartość 2, w 3 lub 4 klasach uzyskano wartość „, \\
\hline Średni & 1 lub 2 klasy uzyskały wartość 3, w 3 lub 4 klasach uzyskano wartość „,” \\
\hline Duży & 1 lub 2 klasy uzyskały wartość 4, w 3 lub 4 klasach uzyskano wartość „3” \\
\hline Bardzo duży & 1 lub 2 klasy uzyskały wartość 5, w 3-4 klasach uzyskano wartość „4” \\
\hline Katastrofalny & 3 lub 4 klasy uzyskały wartość 5 \\
\hline
\end{tabular}

Źródło: opracowanie własne, 2013.

\subsection{Metody ochrony przed powodziami}

W dotychczasowej praktyce ochrony przeciwpowodziowej jako główne cele traktowano ochronę ludzi oraz minimalizację strat powodziowych. W związku z tym podejmowano głównie działania techniczne (Bobiński, Żelaziński 1996; Bajorek 2001). Uważano, że zbyt słabe zagospodarowanie hydrotechniczne dolin rzecznych nie pozwala skutecznie redukować większych czy wręcz katastrofalnych wezbrań i chronić przed utratą majątku (Grochulski 1975). Jak pokazały wieloletnie obserwacje, urządzenia te często zawodzą, zaś wiara w ich niezawodność powoduje eskalację zagrożenia życia (Bobiński, Żelaziński 1996). W działaniach pomijano również aspekt środowiskowy. Dlatego niezwykle ważnym zadaniem jest opracowanie map i określenie stref zagrożenia oraz ustanowienie ograniczeń, co do sposobu użytkowania terenów zaliczonych do poszczególnych kategorii (Bobiński, Żelaziński 1996). Ochrona przeciwpowodziowa należy do obowiązków publicznych, które muszą być realizowane zarówno przez jednostki administracji rządowej, jak i samorządowej zgodnie z ustawą z 18 lipca $2001 \mathrm{r}$. Prawo wodne. Ustalają one normy prawne, procedury formalne i środki tworzenia warunków ochrony obywateli przed zjawiskami stwarzającymi niebezpieczeństwo zarówno dla zdrowia, życia, jak i majątku (Bac 2011).

W ostatnim czasie znacząco zmieniło się jednak podejście do metody ochrony przed powodzią. Obecnie odchodzi się od założenia, że istnieje skuteczna metoda ochrony przed powodzią, do filozofii, według której całkowita ochrona 
jest niemożliwa, zatem szkody oraz straty powodziowe można jedynie ograniczać. Podejście to zostało sformułowane w Dyrektywie 2007/60/WE Parlamentu Europejskiego i Rady z 23 października 2007 r. w sprawie oceny ryzyka powodziowego i zarządzania nim, w tzw. Dyrektywie Powodziowej. Niezwykle istotne z punktu widzenia ochrony przed powodzią są zagadnienia ryzyka powodziowego oraz zarządzania nim.

Ochronę przeciwpowodziową należy postrzegać jako działania kompleksowe, obejmujące zarówno techniczne, jak i nietechniczne metody ochrony (Maciejewski, Walczykiewicz 2010). Najkorzystniejszą sytuacją byłoby wyłączenie spod zabudowy obszarów narażonych na zalanie, a dopiero później regulacja fali powodziowej poprzez środki techniczne, w tym obwałowania i zbiorniki wodne (Starkel 1998). Jednak ze względu na to, iż na wielu obszarach jest to niemożliwe, działania z zakresu ochrony przeciwpowodziowej powinny obejmować:

- zapobieganie zagrożeniu powodziowemu, czyli tzw. prewencyjne zapobieganie powstawaniu szkód wywoływanych powodziami poprzez rezygnację z budowy domów mieszkalnych, obiektów przemysłowych, obecnie i w przyszłości na obszarach zalewowych. Niezwykle istotne jest również dostosowywanie obiektów, które powstaną do stopnia zagrożenia powodziowego oraz wspieranie właściwego zagospodarowania terenu, praktyk rolniczych i leśnych. Polityka europejska, a tym samym i krajowa zakłada harmonizację działań realizowanych na mocy obu dyrektyw: Ramowej Dyrektywy Wodnej i Dyrektywy Powodziowej (dużą rolę odgrywać będzie proces planowania przestrzennego);

- ochronę wskutek podejmowania środków strukturalnych i niestrukturalnych w celu zmniejszenia prawdopodobieństwa występowania powodzi lub/i jej wpływu w określonych miejscach;

- gotowość, obejmującą informowanie, a także ostrzeganie ludności o zagrożeniu powodziowym oraz o zasadach postępowania w wypadku jej wystąpienia (zasady ewakuacji);

- postępowanie awaryjne w sytuacji kryzysowej na podstawie planów awaryjnego zarządzania na wypadek wystąpienia powodzi;

- przywracanie normalnych warunków i wyciąganie wniosków, polegające na powracaniu możliwie najszybciej do takich warunków i łagodzeniu skutków społecznych oraz gospodarczych w przypadku osób dotkniętych zalaniem (Drużyńska, Nachlik 2006; Nachlik 2007, 2008; Sieradzka-Stasiak 2010).

„Nowoczesna i skuteczna ochrona przeciwpowodziowa wymaga konsekwentnie prowadzonych, długofalowych i wielokierunkowych działań w skali całego dorzecza. Wiąże się to z koniecznością przełamania wielu schematów i kompleksowego spojrzenia na sposób użytkowania rzek i ich dolin. Dla rozwiązania problemów ujawnionych przez kolejne powodzie konieczna jest ścisła współpraca specjalistów z różnych dziedzin" (Kitowski 2010, s. 48).

Planowanie przestrzenne stanowi niezwykle ważny instrument w minimalizowaniu skutków powodzi na danym obszarze, podobnie jak działania techniczne 
czy operacyjne (Słysz, Pawłowska 2010). „Najskuteczniejszą metodą ochrony przed powodzią jest zaniechanie użytkowania przez człowieka terenów zalewowych w sposób podatny na szkody wywoływane zalaniem. Słuszna zasada »odsunąć człowieka« od wody, może być stosowana jedynie w ograniczonym zakresie. Zarówno w Polsce, jak i w innych krajach historyczne miasta i centra cywilizacji rozwijały się w dolinach rzek, często na terenach zalewowych. Nierealne jest przeniesienie zagrożonych miast i osiedli na teren bezpieczny. Natomiast możliwe i niezbędne jest ograniczanie zabudowy terenów zalewowych w przyszłości. Jest to trudny problem legislacyjny, nie zawsze dostrzegany przez decydentów i urbanistów" (Wołoszyn 2006, s. 157).

Najistotniejszym przepisem prawa, który bezpośrednio wpływa na gospodarkę przestrzenną terenów zagrożonych powodzią, jest przepis art. 881 ustawy Prawo wodne z 18 lipca 2001 r., zgodnie z którym na obszarach zalewowych zabrania się wykonywania robót oraz czynności utrudniających ochronę przed powodzią lub zwiększających zagrożenie powodziowe, w tym:

1) „wykonywania urządzeń wodnych oraz budowy innych obiektów budowlanych;

2) sadzenia drzew lub krzewów, z wyjątkiem plantacji wiklinowych na potrzeby regulacji wód oraz roślinności stanowiącej element zabudowy biologicznej dolin rzecznych lub służącej do wzmacniania brzegów, obwałowań lub odsypisk;

3) zmiany ukształtowania terenu, składowania materiałów oraz wykonywania innych robót, z wyjątkiem robót związanych z regulacją lub utrzymywaniem wód oraz brzegu morskiego, a także utrzymywaniem, odbudową, rozbudową lub przebudową wałów przeciwpowodziowych wraz z obiektami związanymi z nimi funkcjonalne".

Przepis ten w świetle ustawy z 7 lipca 1994 r. Prawo budowlane oznacza zakaz zabudowy tych obszarów. Od zasady tej istnieje w przepisach wyjątek, który zezwala dyrektorowi RZGW w uzasadnionych przypadkach, w drodze decyzji administracyjnej, udzielić zwolnienia od tego zakazu. W związku z tym zarówno w miejscowych planach zagospodarowania przestrzennego, jak i decyzjach o warunkach zabudowy i zagospodarowania terenu możliwe jest dopuszczenie zabudowy, pomimo iż dotyczy to obszarów szczególnego zagrożenia powodzią (Program bezpieczeństwa powodziowego... 2011). Jeśli inwestor uzyska zgodę na budowę obiektu na terenach zagrożonych zalaniem, wówczas należy go odpowiednio zabezpieczyć. Obiekt powinien być wybudowany na podporach, z częścią użytkową znajdującą się powyżej przewidywanego poziomu zwierciadła wody podczas powodzi (Arkuszewski 1994; Fiszer, Sarna 2001).

W ramach gospodarki przestrzennej niezwykle istotnym przepisem dotyczącym ochrony przeciwpowodziowej jest art. 6 pkt. 4 ustawy z 21 sierpnia 1997 r. o gospodarce nieruchomościami, zgodnie z którym budowa i utrzymanie obiektów oraz urządzeń służących ochronie przed powodzią została uznana za cel publiczny. W związku z tym przy ich lokalizacji oraz utrzymaniu stosowane są szczególne procedury, wynikające z ustawy o planowaniu i zagospodarowaniu 
przestrzennym z 27 marca 2003 r. oraz wspomnianej ustawy o gospodarce nieruchomościami (Program bezpieczeństwa powodziowego... 2011).

Problematyka ochrony przeciwpowodziowej jako zagadnienie szczegółowe nie znalazła bezpośrednich odniesień w ustawie o planowaniu i zagospodarowaniu przestrzennym z 27 marca 2003 r. Obowiązek uwzględniania analizowanej problematyki, zakres, tryb opiniowania oraz uzgodnień można wyprowadzić z wykładni przepisów ww. ustawy. Dlatego też tam, gdzie ustawa odwołuje się do uwarunkowań ochrony środowiska przyrodniczego i kulturowego, w tym ochrony bezpieczeństwa oraz mienia ludzi, a także prawidłowego gospodarowania zasobami przyrody, należy rozumieć potrzebę i obowiązek szeroko rozumianej problematyki ochrony przeciwpowodziowej.

Wszędzie tam, gdzie przepisy ww. ustawy mówią o celach publicznych oraz ponadlokalnych celach publicznych, mogą odnosić się do zadań ochrony przed powodzią. Dotyczy do przede wszystkim kształtowania oraz prowadzenia polityki przestrzennej w województwie, koordynacji ponadlokalnych programów zagospodarowania przestrzennego oraz studiów uwarunkowań i kierunków zagospodarowania przestrzennego, a także miejscowych planów zagospodarowania przestrzennego. Miejscowy plan zagospodarowania przestrzennego jest najważniejszym instrumentem planistycznym, gdyż stanowi akt prawa miejscowego. W Polsce nie wprowadzono jednak ustawowego obowiązku sporządzania miejscowych planów zagospodarowania przestrzennego dla obszarów narażonych na niebezpieczeństwo powodzi, co jest szczególnie groźne wobec możliwości zabudowywania tych terenów w drodze indywidualnych decyzji administracyjnych (decyzji o warunkach zabudowy czy też decyzji o ustaleniu inwestycji celu publicznego). Objęcie tych terenów ustawowym obowiązkiem sporządzenia planów miejscowych pozwoliłoby na zawieszanie postępowań administracyjnych w sprawie ustalenia warunków zabudowy do czasu uchwalenia planu (art. 62 ust. 2 ustawy z 27 marca 2003 r. o planowaniu i zagospodarowaniu przestrzennym) (Majda i in. 2011).

Środki techniczne ochrony przeciwpowodziowej dzieli się na czynne oraz bierne (Lambor 1962). Mają one na celu zmniejszenie strat przy małych i średnich wezbraniach. Poza retencją do najczęściej wykorzystywanych sposobów ochrony zalicza się wały przeciwpowodziowe (Więzik 2010).

Czynna ochrona przeciwpowodziowa polega na opanowaniu lub przynajmniej zmniejszeniu przyczyn występowania powodzi dzięki zastosowaniu zabiegów agrotechnicznych i hydrotechnicznych w dorzeczu. Do pierwszej grupy zaliczana jest właściwa uprawa roli, zalesianie zboczy, zabiegi przeciwerozyjne itp. Jest to tzw. retencyjne przysposobienie dorzecza, które doprowadza do zwiększenia wsiąkania wody w glebę, a tym samym zamiany odpływu powierzchniowego na gruntowy. Sprzyja temu tzw. biologiczna obudowa brzegów rzek oraz zboczy dolin rzecznych, budowa zapór przeciwrumowiskowych i suchych zbiorników przeciwpowodziowych, które są wypełniane tylko w trakcie powodzi. Do grupy zabiegów hydrotechnicznych należy budowa zbiorników retencyjnych, najczęściej w górnych biegach rzek (Mikulski 1998). W celu skutecznej realizacji czynnej ochrony 
przeciwpowodziowej powinno się mieć do dyspozycji poldery z zamknięciami, zbiorniki przepływowe, zbiorniki wyrównawcze, kanały ulgi z zamknięciami. Za pomocą zbiorników retencyjnych ze stałą rezerwą przeciwpowodziową oraz suchych zbiorników wodnych i polderów z zamknięciami można sterować przepływem poprzez zmniejszenie kulminacji fali wezbraniowej (Mioduszewski 1994).

Bierna ochrona występuje podczas zagrożenia powodziowego oraz trwania powodzi (Mikulski 1998). Polega ona na zabezpieczeniu obszarów zagrożonych powodzią poprzez ograniczenie zasięgu wody lub zwiększenie przepustowości koryta rzecznego. Najczęściej uregulowaniu podlega koryto rzeczne w celu zwiększenia prędkości przepływu i ochrony terenów przyległych za pomocą obiektów liniowych. Do podstawowych sposobów tej ochrony zalicza się: wały przeciwpowodziowe, kanały ulgi i poldery otwarte (Więzik 2010). Ostatecznym sposobem biernej ochrony przeciwpowodziowej jest ewakuacja ludności oraz dobytku z terenów zagrożonych lub objętych powodzią. Akcja taka jest realizowana w przypadku, gdy inne sposoby zawiodą, na podstawie przygotowanych wcześniej planów ewakuacyjnych (Mikulski 1998).

Obwałowania chronią teren nadrzeczny przed bezpośrednim działaniem wielkiej wody poprzez odgrodzenie od rzeki miast, mniejszych osiedli, zakładów przemysłowych, użytków rolnych, dróg komunikacyjnych itp. i nie dopuszczają do ich zalania. Wały, zwłaszcza obustronne, przynoszą często szereg skutków ujemnych zarówno w dolinie, jak i poza nią. Koncentrują one wielką wodę, w skutek czego zwiększa się prędkość jej ruchu w korycie, co doprowadza do erozji, transportu materiału dennego i przeobrażenia koryta. Z kolei to wpływa na zwiększenie współczynnika szorstkości koryta i zmniejszenie prędkości, a zatem pośrednio powoduje podniesienie kulminacyjnych poziomów wody w rzece, poniżej przestrzeni obwałowanej. Wały zmniejszają także profil przepływającej wielkiej wody, a przez to zwiększają kulminacyjną wysokość zwierciadła wielkiej wody w sposób bezpośredni. Odcinają one znaczne obszary dolin zalewowych, zmniejszają retencję dolinną i zwiększają prawdopodobieństwo wystąpienia powodzi przez podniesienie poziomu wody pomiędzy wałami. Powodują, że cały materiał unoszony w korycie rzeki przez wodę, pochodzący z denudacji dorzecza i erozji łożysk dopływów, pozostaje w korycie rzeki oraz terenie zalewowym międzywala, co doprowadza do jego systematycznego podnoszenia się. Zmniejsza się wskutek tego profil przepływowy i rosną kulminacyjne poziomy wody (Dębski 1950). Obwałowania mogą wywoływać szereg negatywnych konsekwencji, dlatego powinien im towarzyszyć jednoczesny wzrost retencji przeciwpowodziowej w różnej postaci i różnych miejscach dorzecza. Stwierdzenie K. Dębskiego (1950, s. 241) „nie ma obwałowania bez retencjonowania” - jest zatem nadal aktualne.

Obecnie pilnym zadaniem dla władz odpowiedzialnych za bezpieczeństwo powodziowe powinno być wprowadzenie monitorowania stanu kluczowych obwałowań pod kątem ich podatności na przerwanie przy wysokim stanie wody i natychmiastowego wzmacniania wałów zakwalifikowanych jako niespełniające wymaganych standardów odporności na wysokie stany (Zaleski 2010). 


\section{ZJAWISKA POWODZIOWE W WOJEWÓDZTWIE LÓDZKIM}

\subsection{Charakterystyka dolin rzecznych}

Rzeźba terenu stanowi główny czynnik krajobrazowy. Decyduje o różnicach klimatycznych i stosunkach wodnych. Z uwagi na dużą rozciągłość województwa łódzkiego, rzeźba terenu jest zróżnicowana. Opisywany teren to obszar przejściowy pomiędzy strefą wyżyn Polski południowej a strefą nizin środkowopolskich (Kondracki 1998). W podziale dziesiętnym Kondrackiego (1998) część północna województwa zaliczona została do makroregionu Nizin Środkowomazowieckich, obszar na wschód od Łodzi do Wzniesień Południowomazowieckich, na zachód do Niziny Południowowielkopolskiej, na południe do Wyżyny Przedborskiej i Wyżyny Woźnicko-Wieluńskiej. Analizowany teren jest niejednorodny zarówno z punktu widzenia krajobrazowego, jak i geologiczno-hydrogeologicznego, hydrograficznego oraz klimatycznego (Jokiel 2004).

Województwo łódzkie posiada urozmaiconą rzeźbę terenu oraz dostosowany do niej układ sieci rzeczno-dolinnej. Najbardziej wzniesiona południowa część obszaru znajduje się w obrębie Wyżyn Polskich. Fragment południowo-zachodni województwa wraz z załęczańskim odcinkiem doliny Warty zaliczany jest do Wyżyny Wieluńskiej. Wzgórza Radomszczańskie i Opoczyńskie z częścią Pasma Przedborsko-Małogoskiego, zlokalizowane w południowo-wschodniej części województwa łódzkiego, stanowią fragment Wyżyny Przedborskiej, która pod względem geologicznym zaliczana jest do mezozoicznego obrzeżenia Gór Świętokrzyskich. Najwyższe wzniesienia na terenie województwa znajdują się w północnej części Pasma Przedborsko-Małogoskiego w okolicach miejscowości Góry Suche i są to - Góra Fajna Ryba 347 m n.p.m. i Kozłowa 336,8 m n.p.m. oraz na terenie Wzgórz Radomszczańskich - Góra Chełmno 323 m n.p.m. oraz Bąkowa Góra - 282 m n.p.m. Powierzchnia wyżynna nachylona jest łagodnie w kierunku północnym, ku Nizinom Środkowopolskim. W centralnej części województwa łódzkiego, pomiędzy Piotrkowem Trybunalskim a Łodzią, wznosi się garb wysoczyznowy, który stanowi przedłużenie powierzchni wyżynnej. Pomimo że zbudowany jest on z różnorodnych, luźnych osadów czwartorzędowych, to jego wysokość w wielu punktach przekracza 200 m n.p.m. Najwyższe wzniesienia, 
znajdujące się w okolicach Tuszyna, osiągają do $288 \mathrm{~m}$ n.p.m. Porównywalne wysokości występują na Wzniesieniach Łódzkich między Łodzią a Brzezinami, osiągając maksymalną wysokość koło Nowosolnej - 284,1 m n.p.m. Wzniesienia Łódzkie odznaczają się bardzo dużymi, jak na warunki niżowe, wysokościami bezwzględnymi i względnymi, co zauważył Dylik (1948).

Najniżej położone miejsce województwa łódzkiego stanowi ujście Rawki do Bzury, obie rzeki łączą się na wysokości 77,8 m n.p.m. W północno-zachodniej części województwa dno doliny Neru położone jest na wysokości 94,9 m n.p.m.

Rzeźba terenu oraz budowa geologiczna w znaczący sposób wpływają na układ sieci rzecznej oraz dolinnej w granicach omawianego obszaru. Obecny układ hydrograficzny w regionie łódzkim został ukształtowany wraz z ustępowaniem ostatniego na tym obszarze lądolodu. Jak pokazują liczne opracowania (Jewtuchowicz 1967, Klatkowa 1972, Krzemiński 1974, Maksymiuk 1980), sieć hydrograficzna Polski Środkowej pochodzi z fazy kataglacjalnej stadium warty, zlodowacenia środkowopolskiego. Należy jednak zaznaczyć, że istnieją także doliny lub ich fragmenty, których starsze przedwarciańskie założenie jest znane, a nawet udokumentowane, jak i młodsze, których początki i rozwój są związane z okresami późniejszymi (Klatkowa 1984).

Sieć rzeczna obszaru podłódzkiego charakteryzuje się promienistym układem, nawiązującym do umiejscowionych centralnie, kopulastych wzniesień. Rzeki spływają z najwyżej położonych terenów Łodzi w kierunku zachodnim, północnym i wschodnim. W obrębie Wzniesień Łódzkich swoje źródła ma Ner oraz mniejsze rzeki należące do dorzecza Warty, spływające na zachód i północny zachód. W kierunku północnym płynie Bzura oraz jej dopływy. Na południowy wschód do Pilicy spływają Wolbórka i Piasecznica. Rzeki, których źródła znajdują się na Wzniesieniach Łódzkich, są stosunkowo krótkie, ale głębokie, szczególnie w górnych odcinkach.

Promienisty układ występuje również w okolicach Wzgórz Radomszczańskich, chociaż już w mniejszej skali. U podnóża Góry Chełmo swoje źródłowe odcinki mają następujące rzeki, m.in. Widawka, Luciąża oraz mniejsze dopływy Pilicy.

Konsekwencją takiego układu rzek w województwie łódzkim jest występowanie dużych dolin na jego obrzeżach. W zachodniej części płynie Warta, w południowo-wschodniej Pilica, od wschodu Rawka, a na północy Bzura.

Odmienne układy rzeczne powstały w nisko położonych kotlinach. Największy obszar węzłowy znajduje się w okolicach Widawy, w Kotlinie Szczercowskiej. Na krótkim dystansie do dolnej Widawki uchodzą jej prawo- oraz lewostronne dopływy. Drugi układ jest związany z kotlinowatym obniżeniem w okolicach Tomaszowa Mazowieckiego, gdzie Wolbórka, Piasecznica i Bielina uchodzą do Pilicy. Trzecia kotlina w okolicach Łowicza w obrębie Równiny Łowicko-Błońskiej gromadzi wody Bzury wraz z jej dopływami.

Spływające $z$ południa dopływy środkowej Bzury posiadają układ równoległy. Rzeki: Mroga, Uchanka, Zwierzyniec, Skierniewka oraz Rawka, płyną 
południowymi dolinami, rozcinającymi nachyloną w kierunku północnym powierzchnię. Inny układ rzek występuje w części południowo-zachodniej województwa. Na Wyżynie Wieluńskiej rzeki łączą się ze sobą prawie pod kątem prostym i tworzą układ prostokątny. Jest to kształt sieci rzecznej charakterystyczny dla obszarów wyżynnych, pociętych uskokami tektonicznymi oraz innymi spękaniami.

Zróżnicowany kształt sieci rzeczno-dolinnej świadczy o jej złożonej genezie, ponadto ukazuje wpływ rzeźby i budowy geologicznej na rozwój form dolinnych (Kobojek, Kobojek 2005). W układzie cieków zaznaczają się trzy główne kierunki ich przebiegu: południkowy, równoleżnikowy oraz najczęściej występujący skośny, biegnący z południowego wschodu ku północnemu zachodowi (rycina 2.1).

Zasadniczy kształt sieci rzecznej w Polsce Środkowej nadały powtarzające się okresy glacjalne i interglacjalne. Efektem sekwencji zdarzeń w okresie zlodowaceń jest łatwo identyfikowalny układ pradolin, dolin bocznych, przełomowych, które łączą pradoliny. Pradoliny powstawały w okresach deglacjacji, gdy wody z topniejącego lądolodu oraz z obszarów niezlodowaconych spływając, spotykały się i tworzyły ogromne rzeki, płynące równolegle do jego czoła. Większość odpływu koncentrowała się w porze letniej, ponadto w wyniku występowania wiecznej zmarzliny przeważała również erozja boczna nad wgłębną. W efekcie tych procesów pradoliny są szerokie, ale płytkie. Pomiędzy pradolinami powstawały doliny przełomowe. Wody z południa płynęły początkowo starą pradoliną, by następnie przełamywać się przez wały morenowe do nowo uformowanej pradoliny. Tego typu przykłady możemy znaleźć, analizując bieg Warty oraz wielu innych, mniejszych rzek w Polsce Środkowej. W taki sposób powstał charakterystyczny dla tego terenu, łamany układ sieci rzecznej, składający się z odcinków południkowych oraz równoleżnikowych. Specyficzną cechą hydrografii Polski Środkowej są także stosunkowo nisko położone działy wodne, przecinające nawet szerokie obniżenia pradolin (Jokiel 2004).

Analizowane gminy położone są w zlewniach trzech głównych rzek województwa łódzkiego: Warty, Pilicy oraz Bzury. Charakteryzują się one szerokimi równinami zalewowymi, które są $\mathrm{w}$ większości podzielone wałami przeciwpowodziowymi. Wały dzielą dno doliny na strefę międzywala oraz strefę zawala, która jest najczęściej intensywnie zagospodarowana (załącznik 21 do Programu bezpieczeństwa... 2012).

Rzeka Warta to prawostronny dopływ Odry II rzędu, której długość w granicach województwa łódzkiego wynosi ok. $200 \mathrm{~km}$. Dolina tej rzeki ma zmienny charakter, jest częściowo obwałowana (Wojewódzki program małej retencji... 2005). Największe jej dopływy w granicach badanych gmin to: Ner, Żeglina, Myja. W okolicach Działoszyna szerokość równiny zalewowej Warty wynosi od 0,7 km do $1 \mathrm{~km}$ (Haisig, Wilanowski 2000) ${ }^{1}$, na obszarze Sieradza w miejscu ujścia rzeki

1 Nie występują tam wały przeciwpowodziowe, dlatego też do analizy włączono cały obszar zalewowy. 


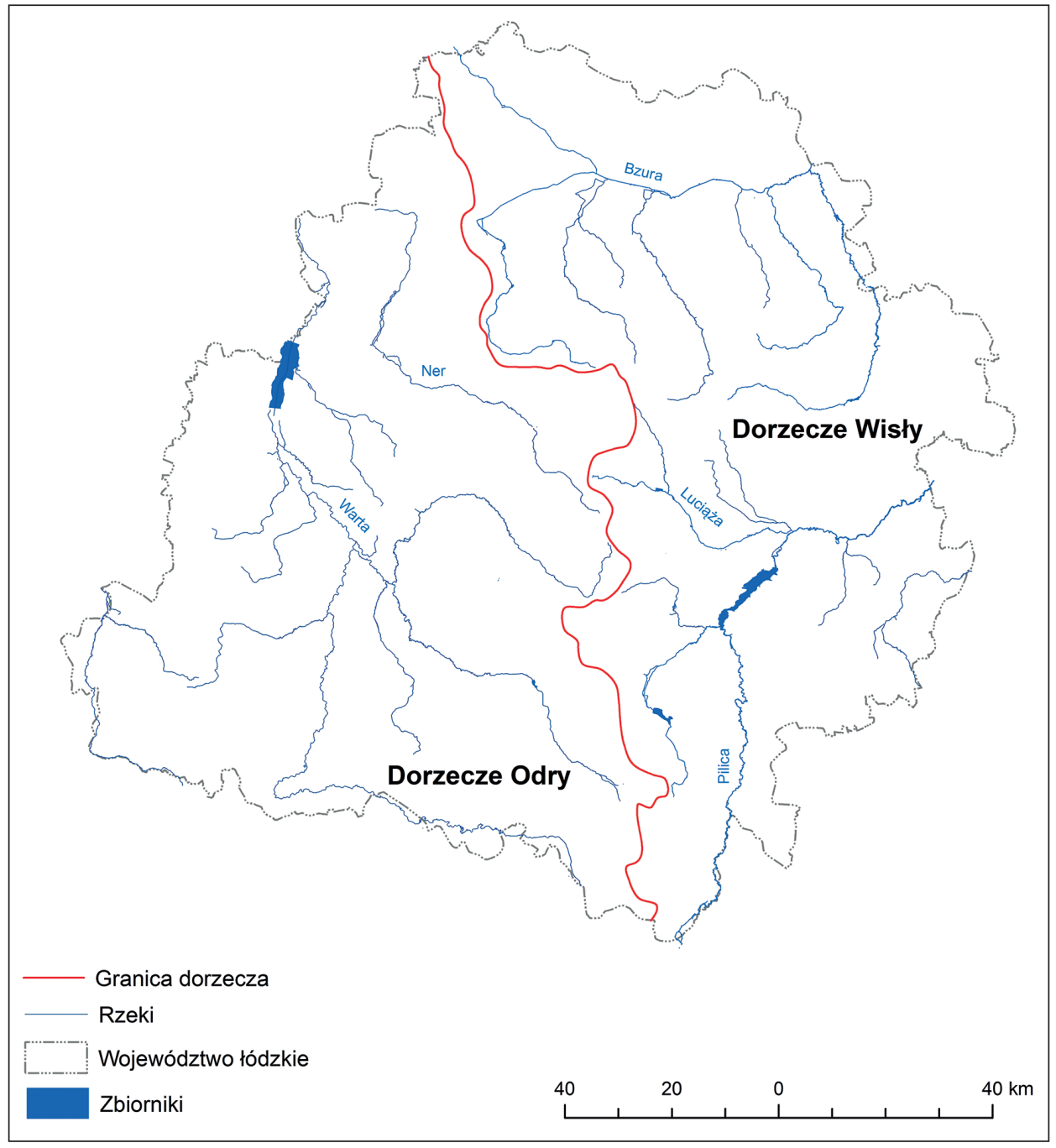

Rycina 2.1. Sieć rzeczna województwa łódzkiego Źródło: opracowanie własne na podstawie danych WZMiUW w Łodzi, 2013

Myja do Warty znacznie się poszerza, osiąga ok. $5 \mathrm{~km}$. W strefie międzywala szerokość dna doliny wynosi ok. $1 \mathrm{~km}$ (Ziomek, Baliński 2007). W mieście i gminie Warta równina zalewowa jest również bardzo szeroka - od ok. 2,9 km do 4,1 km, jednak w związku z istnieniem wałów przeciwpowodziowych analizie poddano tylko jej wycinek - 0,5 km (Klatkowa, Załoba 1990).

Rzeka Bzura jest lewostronnym dopływem Wisły II rzędu, jej długość wynosi $166,2 \mathrm{~km}$, prawie w całości znajduje się ona w granicach województwa łódzkiego. Jednym z jej dopływów jest Ochnia, przepływająca m.in. przez miasto 
Kutno. Dolina rzeki Bzury w znacznej części została zmeliorowana (Wojewódzki program małej retencji... 2005). Na zachód od Łowicza (miasta) szerokość równiny zalewowej wynosi ok. $0,7 \mathrm{~km}$. Dno doliny w centralnej części (w granicach administracyjnych miasta) zwęża się do ok. 0,3-0,4 km. Zostało ono dodatkowe obwałowane i w strefie międzywala jego szerokość wynosi zaledwie $0,15 \mathrm{~km}$ (Brzeziński 1990a).

Pilica to najdłuższy, lewostronny dopływ Wisły II rzędu, w granicach województwa łódzkiego jej długość wynosi $135 \mathrm{~km}$. Do największych dopływów, które znajdują się na obszarze badanych gmin należą: Luciąża, Wolbórka i Czarna. Szerokość dna doliny Pilicy jest bardzo zróżnicowana. W okolicach Żytna wynosi 1,5 km (Hermańska, Smyka 1987), na obszarze Sulejowa jest już znacznie węższa - 0,25-0,5 km (Brzeziński 1990b). Szczególna sytuacja występuje w granicach Tomaszowa Mazowieckiego (miasta). W tym miejscu do Pilicy uchodzą: Wolbórka, Czarna, Lubochenka, w związku z czym równina zalewowa w tej części miasta jest bardzo szeroka, dochodzi nawet do $1,7 \mathrm{~km}$ (Trzmiel 1986). Wały przeciwpowodziowe w najszerszym odcinku równiny zalewowej nie występują, znajdują się jedynie fragmentami przy rzekach: Wolbórka oraz Czarna.

Rzeki województwa łódzkiego posiadają cechy charakterystyczne dla nizinnej części Polski. Równiny zalewowe są szerokie, co sprzyja zalewaniu znacznych obszarów. W związku z tym zostały one w znacznej części obwałowane, a proces zasiedlania odbywa się głównie na terenach niechronionych wałami lub w strefie zawala.

\subsection{Typy powodzi}

W polskiej literaturze hydrologicznej wezbranie jest definiowane jako „znaczne podniesienie się stanu wody płynącej, powstałe w wyniku nadmiernego jej zasilania lub wskutek piętrzenia wody" (Stachy i in. 1996, s. 5). Znaczne podniesienie się stanu wody to efekt wzrostu natężenia przepływu w cieku powierzchniowym. Zasilanie należy interpretować jako spływ po powierzchni terenu wody z opadów atmosferycznych bądź z topniejącej pokrywy śnieżnej. Spływ powierzchniowy występuje w sytuacji, gdy intensywność zasilania przewyższa intensywność infiltracji. Część wód odpływających w trakcie wezbrania pochodzi z odpływu podpowierzchniowego (strefa aeracji) i odpływu podziemnego (strefa saturacji). Definicja ta dopuszcza również możliwość powstania wezbrania na skutek piętrzenia wody przez zatory lodowe i śryżowe, sztormów w ujściowych odcinkach rzek oraz sztucznego zatamowania odpływu (Bajkiewicz-Grabowska, Mikulski 1999). Jest ona jednak niekompletna w szczególności dla hydrologów, gdyż stan podniesionego zwierciadła wody utrzymuje się zwykle przez pewien czas. Dlatego też wezbranie powinno być rozpatrywane jako okres hydrologiczny, w którym stany są wyższe niż przed jego rozpoczęciem. Jest to zjawisko 
wielowymiarowe i powinno być analizowane w różnych kategoriach, m.in. wysokości, czasu trwania, objętości czy też genezy. Wezbranie jest immanentnie związane $\mathrm{z}$ istnieniem rzeki oraz jej funkcjonowaniem $\mathrm{i}$ jedynie po spełnieniu wielu specyficznych warunków może zostać uznane za zdarzenie ekstremalne lub nadzwyczajne (Bartnik, Jokiel 2012).

Stan cieku pod względem hydraulicznym określany jest za pomocą dwóch parametrów, tj. stanu wody oraz natężenia przepływu. Ze względu na to, iż czynniki wywołujące przepływ wody w cieku są zmienne w czasie, to i parametry charakteryzujące go są również zmienne. Zmienność tę dobrze pokazuje tzw. hydrogram przepływu w cieku. Jest nim graficzna lub tabelaryczna prezentacja natężenia przepływu jako funkcji czasu w wybranym przekroju cieku (Radczuk i in. 2001). W rzeczywistości hydrogram jest, ,integralnym wyrażeniem fizycznogeograficznych i klimatycznych charakterystyk, które rządzą relacjami pomiędzy opadem i odpływem danej zlewni odwadnianej przez ciek" (Radczuk i in. 2001, s. 22, za Chow 1959).

Obserwowane gwałtowne zmiany natężenia przepływu są wywoływane na skutek intensywnego odpływu ze zlewni. Sytuacja taka może wystąpić w wyniku zarówno topnienia śniegu, jak i intensywnych opadów deszczu. Wezbranie może mieć charakter długotrwały i występować sezonowo bądź też gwałtowny, gdy jego przebieg w czasie zależy od wielkości i czasu trwania opadu oraz od wielkości i charakteru zlewni. Stanowią one jednak zjawisko naturalne i pożyteczne dla środowiska przyrodniczego, o ile doliny zagrożone zalaniem są prawidłowo zagospodarowane (Radczuk i in. 2001).

Pojęcia wezbrania nie można jednak utożsamiać z pojęciem powodzi (Stachy $i$ in. 1996; Mikulski 1965). Wezbranie jest kategorią hydrologiczną, natomiast powódź to zjawisko o charakterze przyrodniczym i gospodarczym. Zgodnie z ustawą Prawo wodne z 18 lipca 2001 r. ,powódź to takie wezbranie wody w ciekach naturalnych, zbiornikach wodnych, kanałach lub na morzu, podczas którego woda po przekroczeniu stanu brzegowego, zalewa doliny rzeczne albo tereny depresyjne i powoduje zagrożenie dla ludności i mienia". Nie każde wezbranie jest powodzią, ale każda powódź jest spowodowana wezbraniem. Stopień ryzyka powodziowego jest determinowany gęstością zaludnienia, sposobem użytkowania dolin oraz terenów zalewowych, infrastrukturą techniczną itp. Powódź ma również aspekt ekonomiczny, który wiąże się z problemem prawidłowego gospodarowania na terenach zagrożonych zalaniem i podtopieniami z jednej strony oraz wysokością wezbrania z drugiej. W sytuacji, gdy w zalanej dolinie znajduje się majątek o znacznej wartości, można mówić o dużej lub wręcz katastrofalnej powodzi. Najczęściej na skalę powodzi przyjmuje się wielkość szkód, do których zalicza się: zagrożenie zdrowia i życia ludzi, zniszczenia domów, dróg, upraw, zabytków, skażenie terenu i wód substancjami szkodliwymi, utrata miejsc pracy itp. (Radczuk i in. 2001).

Ze względu na genezę powodzi, przyczyny tworzenia się i proces jej przebiegu Lambor (1954) wyróżnił cztery zasadnicze jej typy: opadowe, roztopowe, sztormowe i zimowe (tabela 2.1). 
Tabela 2.1. Systematyka typów powodzi

\begin{tabular}{|c|c|c|c|c|c|c|}
\hline \multirow{2}{*}{\multicolumn{2}{|c|}{$\begin{array}{c}\text { Typ } \\
\text { powodzi }\end{array}$}} & \multirow{2}{*}{ Symbol } & \multirow{2}{*}{ Przyczyny } & \multirow{2}{*}{ Zasięg i charakter } & \multicolumn{2}{|c|}{ Okres występowania } \\
\hline & & & & & ekstremalny & najczestszy \\
\hline \multirow{3}{*}{ 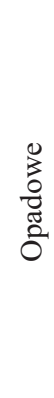 } & \multirow[t]{2}{*}{ 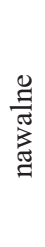 } & On & $\begin{array}{l}\text { Lokalne deszcze } \\
\text { nawalne, burze } \\
\text { termiczne }\end{array}$ & $\begin{array}{l}\text { Lokalne silne powodzie } \\
\text { zarówno na potokach } \\
\text { górskich, jak i małych } \\
\text { ciekach }\end{array}$ & V-IX & VII-VIII \\
\hline & & Of & Deszcze frontalne & $\begin{array}{l}\text { Szeroki zasięg } \\
\text { terytorialny }\end{array}$ & IV $-\mathrm{X}$ & VI-IX \\
\hline & 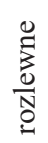 & Or & $\begin{array}{l}\text { Deszcze } \\
\text { frontalne nasilane } \\
\text { orograficznymi }\end{array}$ & $\begin{array}{l}\text { Długotrwałe, groźne } \\
\text { powodzie z obszarów } \\
\text { górskich }\end{array}$ & IV $-\mathrm{X}$ & VI-IX \\
\hline \multicolumn{2}{|c|}{ 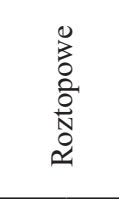 } & $\mathrm{R}$ & $\begin{array}{l}\text { Gwałtowne topnienie } \\
\text { śniegów zasilone } \\
\text { silnymi deszczami } \\
\text { przy zamarzniętej } \\
\text { powierzchni gruntu }\end{array}$ & $\begin{array}{l}\text { Szeroki zasięg } \\
\text { przy sprzyjających } \\
\text { warunkach }\end{array}$ & XII-III & III \\
\hline \multicolumn{2}{|c|}{ 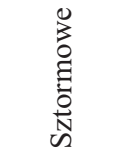 } & $\mathrm{Sz}$ & $\begin{array}{l}\text { Sprzyjająca sytuacja } \\
\text { baryczna }\end{array}$ & $\begin{array}{l}\text { Wybrzeże morskie, } \\
\text { Zalew Wiślany, Zalew } \\
\text { Szczeciński }\end{array}$ & $\begin{array}{c}\text { X-III } \\
\text { VII-VIII }\end{array}$ & XII i I \\
\hline \multirow{2}{*}{ 芩 } & 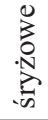 & Zś & $\begin{array}{l}\text { Gwałtowny spadek } \\
\text { temperatury }\end{array}$ & $\begin{array}{l}\text { Lokalne powodzie } \\
\text { w miejscach specjalnie } \\
\text { predestynowanych }\end{array}$ & XII-III & XII i I \\
\hline & 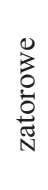 & $\mathrm{Zz}$ & $\begin{array}{l}\text { Spiętrzenie wody } \\
\text { na zatorze w trakcie } \\
\text { spływu lodów, } \\
\text { najczęściej w profilach } \\
\text { mostowych }\end{array}$ & $\begin{array}{l}\text { Lokalne groźne na } \\
\text { rzekach i potokach } \\
\text { w miejscach } \\
\text { o hamowanym spływie } \\
\text { lodów }\end{array}$ & XII-III & III \\
\hline
\end{tabular}

Źródło: Lambor (1954).

Wieloletnie obserwacje rzek pokazują, że obok typów genetycznie jednorodnych, które wyróżnił Lambor (1954), występują również wezbrania typu mieszanego, jak to miało miejsce w końcu stycznia 1953 r. (bardzo groźne na małych ciekach, m.in. Pilicy, Bzury). Wówczas gwałtownemu ociepleniu i topnieniu pokrywy śnieżnej, o grubości przekraczającej $20 \mathrm{~cm}$ w Polsce Środkowej, towarzyszyły opady o niespotykanej, jak na porę zimową, wysokości spadłej wody (Parczewski 1960).

Lambor (1954) nie docenił możliwości wystąpienia wezbrań opadowo-rozlewnych w niżowej części kraju. Ograniczył on występowanie powodzi zatorowo-śryżowych do niektórych rzek nizinnych i nie przewidział, że niewłaściwa zabudowa hydrotechniczna może wywołać katastrofę. 
Podana definicja oraz klasyfikacja wezbrań odpowiada naturalnym, niezmienionym przez człowieka warunkom hydrologicznym. Obecnie do przyczyn wezbrań zalicza się również katastrofy zapór wywołane wadami technicznymi oraz nadmiernym zasilaniem. Zjawiska, takie jak: trzęsienia ziemi, osuwiska, zatory lodowe, pływy morskie i wezbrania sztormowe, zaostrzają zagrożenie powodziowe (Stachy i in. 1996).

Na obszarze województwa łódzkiego można wyodrębnić trzy zasadnicze typy powodzi: roztopowe, zatorowe, opadowe. Największe odpływy notowane są w trakcie roztopów wiosennych. Okresem ich występowania są miesiące zimowe (luty), ze specjalnym nasileniem w marcu (Starkel 1999).

W zlewni rzeki Warty wysoki stan wód ma miejsce najczęściej na przełomie lutego oraz marca (Mikulski 1957) (rycina 2.2), natomiast w zlewni rzeki Bzury i Pilicy w końcu marca oraz w pierwszych dniach kwietnia (rycina 2.3) (Plan operacyjny... 2011).

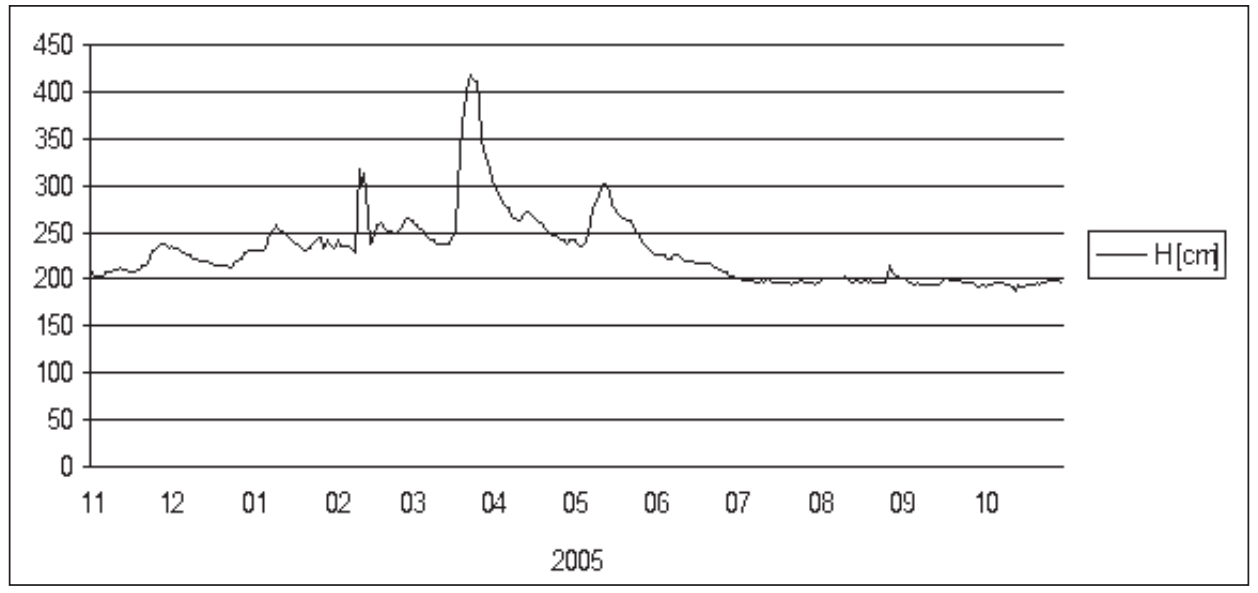

Rycina 2.2. Dzienne stany wody w Sieradzu w 2005 r., zlewnia rzeki Warty Źródło: opracowanie własne na podstawie danych Instytutu Meteorologii i Gospodarki Wodnej PIB

Powodzie roztopowe są na ogół częstsze oraz bardziej dotkliwe od pozostałych typów, ze względu na niższe temperatury. Wysokie stany wód będące następstwem topnienia śniegu występują na obszarze całego województwa. Wylewy pojawiają się po zimie (z obfitymi opadami śniegu), gdy wystąpi nagły wzrost temperatury powietrza, powodujący szybkie tajanie śniegu często wzmocnione wskutek ciepłych, obfitych opadów deszczu. Zjawisko to jest dodatkowo wzmacniane przez zamarznięty grunt, który uniemożliwia infiltrację wody opadowej i roztopowej. Na obszarach nizinnych zasilanie ze śniegu zachodzi bardzo intensywnie, gdyż ociepleniu podlegają duże obszary. Wskutek tego w krótkim czasie znaczna ilość wody przedostaje się do koryt rzecznych, wywołując dużą 


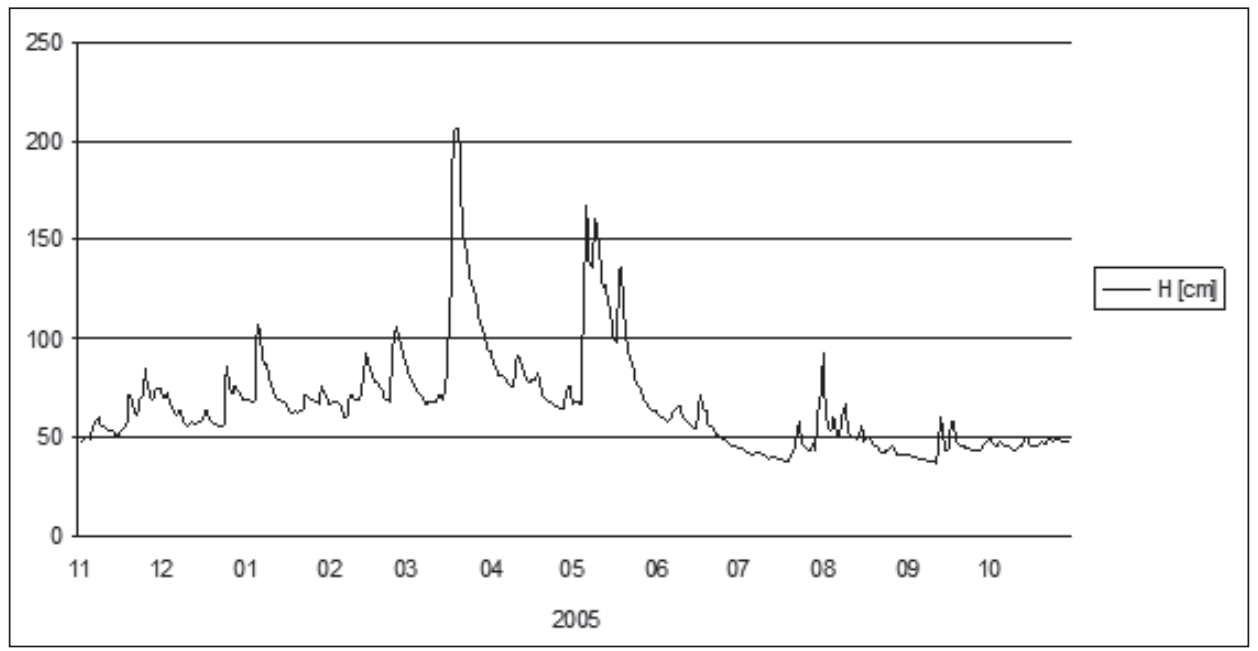

Rycina 2.3. Dzienne stany wody w miejscowości Kwiatkówek w 2005 r., zlewnia rzeki Bzury Źródło: opracowanie własne na podstawie danych Instytutu Meteorologii i Gospodarki Wodnej PIB

falę wezbraniową. W regionie łódzkim średni odpływ w miesiącach wiosennych wynosi od $130 \%$ do $180 \%$ średniego odpływu rocznego.

Wezbrania zatorowe również powstają na wiosnę. Wywoływane są spiętrzeniem wody w korycie rzeki, na skutek bariery z lodu lub śryżu oraz przez nagromadzenie pni drzew albo ław trawiastych. Nasilenie zjawisk lodowych jest uzależnione od klimatu i ulega okresowym przemianom. Chociaż zatory lodowe na rzekach zdarzają się rzadko, to jednak powodują szczególnie niebezpieczne powodzie. Są one wyższe w porównaniu do wezbrań rzeki niezlodzonej. Podczas bardzo mroźnych zim, kiedy wody zamarzają na dużą głębokość, odwilż może wprowadzić w ruch ogromne masy kry. Jeśli zostaną one nagromadzone w przewężeniu koryta, doprowadzą do zagrodzenia biegu rzeki. Gdy ta przeszkoda okaże się wytrzymała, wody piętrzą się na niej i w końcu powstają wylewy. Wskutek wytworzenia się zatoru na rzece, dochodzi do gwałtownego przyboru wody. Inne wylewy tworzą się poniżej miejsca zatoru, gdy powstrzymywana woda zniesie zaporę. Wezbrania zatorowe mają lokalne pochodzenie i z tego względu intensywnie atakują tylko krótkie odcinki dolin. Na obszarze województwa łódzkiego powodzie zatorowe powstawały często w latach 50. i 60. na Grabi (Kobojek, Kobojek 2005). Obecnie z zatorem lodowym mamy do czynienia w regionie łódzkim na następujących rzekach: Warta, Bzura, Luciąża, Czarna Konecka, Pilica, Widawka (Plan operacyjny... 2011). Powodzie zimowe, powstające w wyniku podniesienia się zwierciadła wody na skutek występowania zjawisk lodowych, występują najczęściej w grudniu, styczniu oraz lutym i marcu.

Powodzie opadowe wywoływane są przez opady deszczu, które różnią się zarówno natężeniem, jak i zasięgiem obszarowym (Więzik 2010). Wezbrania 
dużych rzek nizinnych narastają powoli, na co ma wpływ szeroka dolina w dolnym biegu rzeki. Im bardziej rozległe jest dorzecze, tym czas trwania deszczu musi być dłuższy, aby wywołać powódź. Na rzekach odwadniających duże obszary powodzie praktycznie nigdy nie są wynikiem pojedynczego, silnego deszczu, lecz najczęściej pewnego ciągu średnich ulew, oddzielonych od siebie krótkimi odstępami czasu. Kiedy opady trwają długo oraz obejmują dużą część dorzecza, może dojść do nakładania się wezbrań na poszczególnych dopływach. Dzięki analizie stosunków hydrograficznych w górnym oraz środkowym biegu rzeki można przewidzieć nadejście fali powodziowej w biegu dolnym. Tego typu powodzie występują najczęściej w dolinie Pilicy, czasem Warty oraz w mniejszych dolinach (Kobojek, Kobojek 2005).

Na obszarze województwa łódzkiego przyczynami powodzi mogą być również awarie zbiorników wodnych. Potencjalne zagrożenie, wynikające z możliwości wystąpienia uszkodzenia zapór czołowych zbiorników retencyjnych, istnieje na trzech rzekach: Warta w miejscowości Siedlątków - zbiornik Jeziorsko, Pilica w miejscowości Smardzewice - zbiornik Sulejów oraz Luciąża - zbiornik Cieszanowice (Plan operacyjny... 2011).

\subsection{Powodzie historyczne}

Pierwsze wiadomości o powodziach pochodzą ze starych kronik oraz archiwów (Mikulski 1962, 1963, 1997, 1998). Sporo miejsca poświęcił im Jan Długosz w Rocznikach, czyli kronikach sławnego Królestwa Polskiego.

Już na początku XIX w. rozpoczęto systematyczne obserwacje wahań stanów wody, dzięki czemu możliwe było zebranie dokładniejszych informacji o rozmiarach powodzi (Mikulski 1998). W tym wieku na przestrzeni 67 lat wystąpiło 20 groźnych powodzi, co daje jeden wylew powodziowy na 3,35 lat (Tyszka 1954). Największą w tym okresie znaną powodzią w Polsce, zarówno pod względem wysokości wezbrania, jak i zasięgu terytorialnego, było wezbranie w sierpniu 1813 r., które wystąpiło najsilniej na górnej Wiśle i Dunajcu, a także jako jedno z większych na środkowej Wiśle, które spowodowało wielką katastrofę w jej delcie. Wezbranie to wystąpiło również na górnej i środkowej Odrze. Była to największa powódź XIX w. w środkowej Europie. W Polsce doprowadziła do ogromnych szkód gospodarczych, zebrała ofiary w ludziach, zniszczyła wiele wałów przeciwpowodziowych, mostów, zalała dzielnice mieszkalne oraz osiedla.

Kolejną wielką powódź wywołało wezbranie w lipcu 1844 r., z najwyższym stanem wody m.in. w całym biegu środkowej Wisły. Najprawdopodobniej znaczny wpływ na tę sytuację miały wody wniesione m.in. przez Pilicę. Największy po 1813 r. zasięg terytorialny miała powódź w marcu 1888 r., gdyż objęła ona prawie całą nizinną część Polski (Mikulski 1998). 
Ze statystyki wezbrań wynika, że w XX w. w dorzeczu Wisły wystąpiło 30 wielkich powodzi, największe w latach: 1903, 1924, 1927, 1934, 1938, 1947, 1960, 1962, 1970, 1972, 1979, 1980, 1982, 1983, 1997. Natomiast w dorzeczu Odry najbardziej dotkliwe były powodzie z lat: 1903, 1924, 1930, 1938, 1940, 1941, 1947, 1953, 1965, 1977, 1985 oraz 1997. Na tej podstawie można ocenić, że w dorzeczu Wisły powodzie w XX w. pojawiały się średnio co 3 lata, natomiast w dorzeczu Odry, co ok. 5 lat (Maciejewski i in. 2011).

W marcu 1924 r. wystąpiła powódź analogiczna pod względem zasięgu do powodzi z 1888 r. W 1940 r. zanotowano również rozległą powódź roztopową w nizinnej części kraju, o niemal analogicznym zasięgu do powodzi z lat 1888 i 1924.

Jedną z większych powodzi po II wojnie światowej spowodowało wezbranie w marcu 1947 r., które było dodatkowo spotęgowane licznymi zatorami lodowymi, szczególnie groźne w Polsce Środkowej (głównie górna Warta) (Mikulski 1998). Powódź ta pokazała, jakie niebezpieczeństwo kryje się w niekorzystnym układzie geograficznym rzek polskich, płynących (poza małymi wyjątkami) z południa na północ. Wiosenne ocieplenie następuje zazwyczaj wcześniej na południu Polski niż na północy, w wyniku czego ruch lodów rozpoczyna się wcześniej u źródeł rzek niż u ich ujścia. Lód nie ma swobodnego odpływu, w związku z czym gromadzi się na granicy odcinków jeszcze nieodtajanych, tworząc większe lub mniejsze zatory. Spiętrzenia wody, które powstają poza zatorami, powodują wylewy rzek poza wały, przerywanie ich, zalewanie obszarów przybrzeżnych. W 1947 r. lody w górnym odcinku Wisły i Odry ruszyły miesiąc wcześniej niż w dolnym. Kolejnym czynnikiem, który miał wpływ na powódź, był bardzo długo utrzymujący się mróz i związana z tym grubość lodu, wynosząca na większości rzek od $40 \mathrm{~m}$ do $60 \mathrm{~m}$, a nierzadko dochodząca nawet do $1 \mathrm{~m}$. Do uniesienia tak grubego lodu, pękającego w wielkich taflach, potrzebna jest wielka ilość oraz prędkość wody. Przebieg pochodu lodów byłby znacznie mniej szkodliwy, gdyby rzeki były słabiej zasilone przez wody pochodzące $z$ topniejącego śniegu, ponieważ przy mniejszych ilościach wody i niższych stanach, pochód lodów byłby opóźniony, większe ilości tajałyby na miejscu, zaś energia cieńszych i wolniej spływających brył lodowych byłaby mniejsza. Tak się nie stało, gdyż zawinił trzeci czynnik, czyli wyjątkowo niekorzystny rozkład opadów śnieżnych, których największe nasilenie przypadło na drugą połowę lutego i pierwszą połowę marca, a więc na okres bezpośrednio poprzedzający ruszenie lodów. W związku z tym ani parowanie, ani wsiąkanie nie zdążyło odegrać poważniejszej roli i ostatecznie cała ilość śniegu stopniała, a następnie spłynęła w krótkim okresie, dając katastrofalne wezbranie (Balcerski 1947).

Podobny charakter do powodzi z 1940 r., jednak o wyraźnie mniejszym nasileniu, miała powódź z 1951 r., występująca na niżu w marcu. Specyficzna była również powódź zimowa w styczniu 1953 r., powstała w wyniku nagłej odwilży i ciepłych deszczów w dorzeczach kilku mniejszych rzek, m.in. Bzury (Mikulski 1998). Powodzie na małych ciekach pojawiają się niespodziewanie 
z hydrologicznego punktu widzenia, w związku z czym ich przewidywanie opierać się może niemal całkowicie na prognozie meteorologicznej. Powódź w 1953 r. rozpoczęła się od małych cieków nizinnych. W zimie powodzie roztopowe na małych ciekach, w przeciwieństwie do letnich powodzi, obejmują ostatecznie duże obszary, gdyż tajanie pokrywy śnieżnej nie jest zjawiskiem o charakterze lokalnym, jak również nie jest nim długotrwały opad. Bezpośrednią przyczyną wystąpienia powodzi roztopowej było przemieszczanie się nad Polską głębokiego obszaru niskiego ciśnienia oraz rozbudowana intensywna strefa opadów, w związku z czym wysokość spadłej wody na obszarze powodziowym osiągnęła wartości rzadko spotykane o tej porze roku. Wśród czynników meteorologicznych towarzyszących omawianej powodzi, trzy z nich zadecydowały o jej wystąpieniu:

- ilość wody zawartej w pokrywie śnieżnej, łącznie z ilością wody spadłej w okresie powodzi w postaci stałej i ciekłej;

- szybkość topnienia, zależna od temperatury powietrza, ilości spadłej wody w postaci deszczu, turbulencji, prędkości wiatru oraz od warunków niesprzyjających parowaniu śniegu i wody;

- wartość współczynnika spływu uzależniona od zlodzenia dolnej części pokrywy lodowej oraz od przemarznięcia gruntu.

Pod koniec stycznia 1953 r. polska służba prognoz hydrologicznych została zaalarmowana meldunkiem o gwałtownym przyborze wody na rzece Ochni, lewobrzeżnym dopływie Bzury (z 28 na 29 stycznia przybór wody wyniósł w Kutnie $148 \mathrm{~cm}$ ), następnie również na Bzurze i Pilicy (tabela 2.2).

Na omawianym obszarze opad rozpoczął się 27 stycznia 1953 r. w godzinach popołudniowych, początkowo jako śnieg, następnie ciągły deszcz, a w południowej części mżawka. Na obszarze małych cieków nizinnych objętych powodzią największa ilość wody spadła od godz. 19.0027 stycznia 1953 r. do godz. 19 dnia następnego. Opady te wpłynęły tylko nieznacznie na stopnienie pokrywy śnieżnej. W dużym stopniu umożliwiły one spływ śryżu oraz dostarczyły znacznej, jak na porę zimową, ilości wody, która w całości zasiliła najbliższe cieki. 27 stycznia 1953 r. o godz. 7:00 okolice Kutna znajdowały się w zatoce niskiej pokrywy śnieżnej, która ciągnęła się przez Polskę z NW ku SE. Kolejnego dnia, mimo spadłego śniegu, wysokość pokrywy śnieżnej pozostała w zasadzie na tym samym poziomie, w związku ze wzrostem temperatury powietrza powyżej $0^{\circ} \mathrm{C}$ i wystąpieniem deszczu. Wysokości pokrywy śnieżnej były dalekie od wartości maksymalnych, spotykanych w tej porze roku, dlatego to nie ilości śniegu, a jego gwałtowne tajanie i szybki spływ były jednym z głównych elementów, który zadecydował o nagłym wezbraniu cieków nizinnych. 28 stycznia 1953 r. na obszarze objętym powodzią nastąpił wzrost temperatury do $4^{\circ} \mathrm{C}$, a w kolejnym dniu do $5-6^{\circ} \mathrm{C}$. W tym okresie tylko niewielka ilość ciepła zużywała się na parowanie na skutek wilgotności względnej powietrza bliskiej stanu nasycenia, dlatego przeważająca część energii cieplnej powietrza została wykorzystana na topnienie pokrywy śnieżnej. Najistotniejszy wpływ na tajanie pokrywy śnieżnej wywiera silny 
Tabela 2.2. Charakterystyka powodzi w styczniu 1953 r.

\begin{tabular}{|c|c|c|c|c|c|c|c|c|c|}
\hline \multirow[b]{2}{*}{$\begin{array}{c}\text { Nazwa } \\
\text { rzeki }\end{array}$} & \multirow[b]{2}{*}{$\begin{array}{l}\text { Wodo- } \\
\text { wskaz }\end{array}$} & \multirow{2}{*}{$\begin{array}{c}\text { Dzień } \\
\text { godz. } \\
\text { stan } \\
\text { wody } \\
(\mathrm{cm})\end{array}$} & \multirow{2}{*}{$\begin{array}{c}\text { Max } \\
\text { przyrost } \\
\text { dobowy } \\
(\mathrm{cm})\end{array}$} & \multicolumn{2}{|c|}{ Kulminacja } & \multirow{2}{*}{$\begin{array}{c}\text { Średnia } \\
\text { wielka } \\
\text { woda } \\
(\mathrm{cm})\end{array}$} & \multirow{2}{*}{$\begin{array}{l}\text { Abso- } \\
\text { lutne } \\
\max \\
(\mathrm{cm})\end{array}$} & \multirow{2}{*}{$\begin{array}{c}\text { Stan } \\
\text { alar- } \\
\text { mowy } \\
(\mathrm{cm})\end{array}$} & \multirow[b]{2}{*}{ Uwagi } \\
\hline & & & & $\begin{array}{l}\text { dzień } \\
\text { godz. }\end{array}$ & $\begin{array}{l}\text { stan } \\
\text { wody } \\
(\mathrm{cm})\end{array}$ & & & & \\
\hline Ochnia & Kutno & $\begin{array}{l}28.01 \\
7: 00 \\
46 \\
\\
29.01 \\
7: 00 \\
194\end{array}$ & 148 & $\begin{array}{l}29.01 \\
23: 30\end{array}$ & 266 & 242 & 314 & 150 & $\begin{array}{l}\text { Pierwsza } \\
\text { informacja } \\
\text { nadeszła } \\
29.01 \text { o godz. } \\
16.25 \\
\text { o ewakuacji } \\
\text { niżej } \\
\text { położonych } \\
\text { gospodarstw, } \\
\text { przy stanie } \\
\text { wody } 254 \mathrm{~cm}\end{array}$ \\
\hline Bzura & Łęczyca & $\begin{array}{l}28.01 \\
7: 00 \\
208 \\
\\
29.01 \\
7: 00 \\
258\end{array}$ & 50 & $\begin{array}{c}30.01 \\
7: 00\end{array}$ & 278 & - & - & 200 & - \\
\hline Bzura & Łowicz & - & - & $\begin{array}{l}31.01 \\
18: 00\end{array}$ & 308 & 190 & 314 & 140 & - \\
\hline Pilica & Sulejów & $\begin{array}{l}29.01 \\
7: 00 \\
114 \\
\\
30.01 \\
7: 00 \\
190\end{array}$ & 76 & $\begin{array}{l}31.01 \\
16: 00\end{array}$ & 260 & 193 & 290 & 180 & $\begin{array}{l}28.01 \\
\text { o godz. 8:00 } \\
\text { stan wody } \\
66 \mathrm{~cm}\end{array}$ \\
\hline
\end{tabular}

Źródło: Parczewski (1954, s. 154).

wiatr, a także związane z nim intensywne ruchy turbulencyjne, doprowadzające do pokrywy śnieżnej coraz to inne porcje powietrza, nie dopuszczając zatem do spadku temperatury powietrza oraz rozprowadzając ochłodzenie na duże masy powietrza. Wpływ wiatru był tym większy, że np. zlewnia Ochni objęta jednym z ośrodków największych prędkości wiatru pozbawiona jest prawie zupełnie większych obszarów leśnych, które mogłyby przyczynić się do rozłożenia okresu zaniku warstwy śnieżnej na kilka dni. Znaczny wpływ na zanik pokrywy śnieżnej miał również deszcz, z uwagi na rozdrabnianie pokrywy śnieżnej, w wyniku czego następował jej spływ. 
W styczniu 1953 r. zaistniały warunki sprzyjające zlodzeniu przygruntowej warstwy pokrywy śnieżnej w wyniku korzystnego rozwoju sytuacji atmosferycznej:

- pięciokrotnych odwilży poprzedzielanych okresami mroźnymi, wywołującymi częściowe topnienie oraz ponowne zamarzanie pokrywy śnieżnej;

- ograniczeniu się odwilży prawie wyłącznie do pory dziennej, dzięki czemu woda powstała z tajania w ciągu dnia nie spływała, lecz zamarzała przeważnie w przygruntowej warstwie pokrywy śnieżnej;

- występowaniu średnio co trzeci dzień deszczu ze śniegiem lub deszczu oraz mżawki, padających na pokrywę śnieżną i zamarzających w trakcie nocnego obniżania się wartości temperatury powietrza poniżej $0^{\circ} \mathrm{C}$;

- dwukrotnego występowania mżawki przechłodzonej, powiększającej zlodzenie pokrywy śnieżnej.

Wszystkie te zjawiska doprowadziły do wytworzenia się korzystnych warunków do zlodzenia pokrywy śnieżnej, w szczególności jej dolnej warstwy, na obszarze objętym powodzią roztopową, a zatem do łatwego spływu wody deszczowej oraz topniejącego śniegu (Parczewski 1954).

Powódź na omawianym obszarze wystąpiła także w lipcu 1960 r. Wisła osiągnęła wówczas bardzo wysokie stany wody niemal w całym biegu. Powódź z 1960 r. jest porównywalna do tej z 1934 r., z tym że ta pierwsza miała groźniejszy przebieg w środkowym i dolnym biegu Wisły.

Znaczne rozmiary osiągnęły również powodzie opadowe z lat 1962, 1970, 1980 (stany alarmowe zostały przekroczone na dopływach Wisły środkowej już na początku czerwca), 1982 (Mikulski 1998; Ostrowski i in. 2011).

Powódź w 1997 r. na środkowym odcinku Wisły nie miała takiej skali, jak powódź w dorzeczu Odry. Poziom dopływów lewobrzeżnych Wisły środkowej podniósł się na skutek znacznych opadów i wystąpiły lokalne wezbrania, których kulminacje na Pilicy przekroczyły stany alarmowe. Wezbranie na Pilicy powyżej zbiornika Sulejów składało się z dwóch kulminacji. Pierwsza z nich minęła profil Sulejów 14 lipca przy stanie $300 \mathrm{~cm}$, przekraczając tym samy stan alarmowy o $70 \mathrm{~cm}$. Druga wystąpiła 12 dni później (26 lipca), również przy stanie $300 \mathrm{~cm}$ (Barczyk i in. 1999). Na Warcie powódź ta jest klasycznym przykładem transformacji fal wezbraniowych w zlewniach rzek nizinnych. Wezbranie na górnej Warcie było wysokie, w Działoszynie przekroczone zostało maksimum absolutne o $30 \mathrm{~cm}$, natomiast w niżej położonym Sieradzu zabrakło kilku centymetrów. Postęp fali powodziowej na Warcie był bardzo powolny: od Działoszyna do Gorzowa Wielkopolskiego fala przemieszczała się 1 miesiąc (od 10 lipca do 10 sierpnia). Zbiornik Jeziorsko przejął znaczne masy wody, dlatego w dolnym biegu rzeki doszło do spłaszczenia fali powodziowej (Dubicki 1999).

W latach 2001-2010 zanotowano 3 przypadki powodzi o zasięgu regionalnym w dorzeczach Wisły i Odry w: 2001 r., 2005 r. oraz 2010 r. (Ostojski i in. 2011). 
W 2001 r. na przełomie lipca i sierpnia wystąpiła katastrofalna powódź opadowa, która na wielu obszarach przyjęła charakter klęski żywiołowej. Tym razem jednak miejscem największego nasilenia groźnych zjawisk było dorzecze Wisły.

W 2010 r. miała miejsce katastrofalna powódź opadowa, która przyniosła duże szkody materialne i ofiary w ludziach. W okresie od stycznia do marca 2010 r. w zlewni rzeki Warty zanotowano duże sumy opadów, wyższą niż przeciętnie w wieloleciu pokrywę śnieżną, a także wysoki poziom wód podziemnych. Było to największe wezbranie opadowe od 1947 r., ale trzecie pod względem zarejestrowanych wysokości stanów wody w tym okresie. Poziomy wody znacznie przekraczały stany alarmowe, a wezbranie zaliczono do krótkotrwałych, gdyż trwało 19 dni. W dniu 18 maja stany wody powyżej zbiornika Jeziorsko były zbliżone do stanów alarmowych, natomiast poniżej przekraczały je. Zaznaczał się wpływ polderu Słońsk na obniżenie poziomu wody. Na wysokość fali wezbraniowej od Uniejowa do ujścia Warty widoczny wpływ miały poldery przy ujściu Neru. W 2010 r. wody zalały tereny, które zostały podtopione w marcu w wyniku wezbrania roztopowego, a opady majowe praktycznie w całości zostały odprowadzone do rzeki. Na prędkość przemieszczania się fali wezbraniowej miały również wpływ kulminacje na dopływach (Tadeuszewski, Wilczak 2011).

Środkowa i dolna Wisła jest odcinkiem o deszczowo-śnieżnym reżimie odpływu. Znaczne rozmiary osiągają tu wezbrania roztopowe. Charakterystyczną cechą powodzi z 2010 r. było wystąpienie dwóch prawie równorzędnych maksimów. Woda napływająca z górnej Wisły oraz wysokie stany na Wiśle środkowej spowodowały, że w niektórych miejscach maksimum drugiej fali powodziowej było wyższe niż pierwszej i stanowiło poważne zagrożenie szczególnie tam, gdzie doszło do uszkodzenia wałów przeciwpowodziowych (Ostrowski i in. 2011).

Na podstawie analizy literatury dotyczącej historii powodzi w Polsce do powodzi katastrofalnych w województwie łódzkim w XX w. zaliczamy te z 1924 r., 1940 r. oraz 1947 r. Natomiast powódź w styczniu 1953 r. miała charakter lokalny. W XXI w. największe szkody wywołała powódź z 2010 r. (rycina 2.4).

W badanych gminach powodzie, które zostały udokumentowane, wystąpiły w latach: 1947, 1953, 1960, 1962, 1963, 1965, 1966, 1979, 1982, 1997, 1999, 2001, 2005, 2010 (tabela 2.3). Były to przede wszystkim wezbrania roztopowe oraz opadowe. W Sulejowie w 1960 r. oraz w Tomaszowie Mazowieckim w 2005 r. doszło do powodzi na skutek awarii urządzeń wodnych lub infrastruktury technicznej (Wstępna ocena... 2011). 18 marca 2005 r. nastąpiło przerwanie obwałowania na Stawie Starzyckim, zlokalizowanym na rzece Czarna Bielina, w Tomaszowie Mazowieckim. Wpływ na to miało kilka czynników:

- wysoki opad, którego efektem był przybór wody w rzekach na obszarze miasta;

- znaczny wzrost temperatury powietrza, powodujący nagłe tajanie pokrywy śnieżnej; 


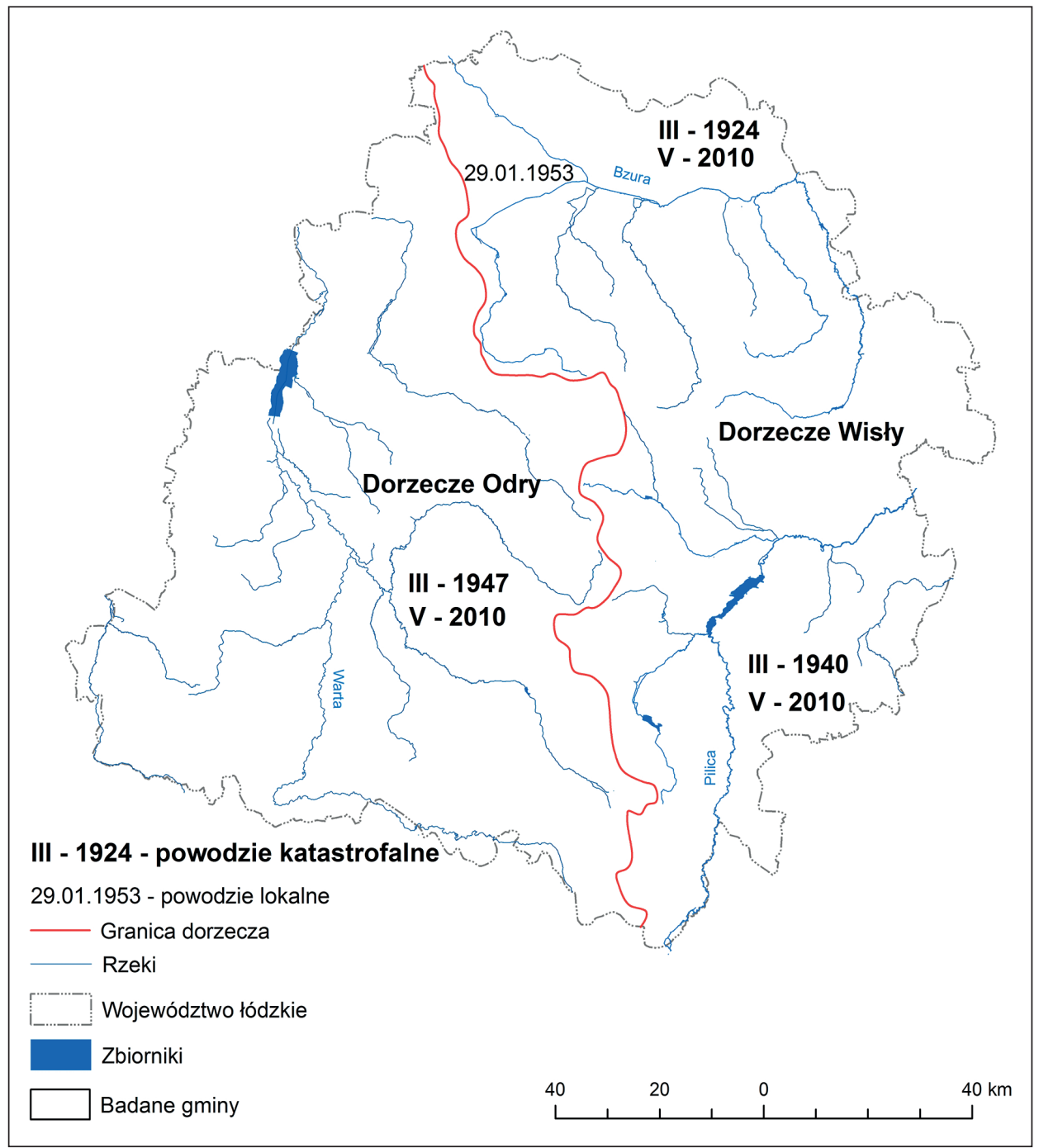

Rycina 2.4. Katastrofalne powodzie w XX i XXI w. na obszarze województwa łódzkiego Źródło: opracowanie własne na podstawie: Mikulski (1954)

- zalegająca na stawie pokrywa lodowa o grubości 0,15-0,2 m;

- zły stan techniczny urządzeń hydrotechnicznych oraz obwałowania;

- utrudniony odpływ wody na skutek zatrzymania zanieczyszczeń na kratach, na wlocie do poszczególnych otworów urządzenia zrzutowego (Batog 2007).

Na skutek tej powodzi straty, które oszacowano na $7 \mathrm{mln} 694$ tys. zł, poniosło osiem firm, Urząd Miasta, Wojewódzki Zarząd Melioracji i Urządzeń Wodnych w Łodzi, Polski Związek Wędkarski oraz 72 osoby prywatne. Doszło 
również do zalania podstacji energetycznej przy ul. Przędzalnianej (http://tomaszowmazowiecki.naszemiasto.pl).

Tabela 2.3. Powodzie historyczne w gminach województwa łódzkiego o bardzo dużym i dużym wskaźniku ryzyka powodziowego

\begin{tabular}{|c|c|c|}
\hline $\begin{array}{l}\text { Rok } \\
\text { wystąpienia } \\
\text { powodzi }\end{array}$ & $\begin{array}{l}\text { Liczba gmin, } \\
\text { w których } \\
\text { wystąpiły } \\
\text { powodzie } \\
\text { (szt.) }\end{array}$ & Gminy, w których wystąpiła powódź \\
\hline 1947 & 4 & Burzenin, Działoszyn, miasto i gmina Sieradz \\
\hline 1953 & 7 & $\begin{array}{l}\text { Inowłódz, Kutno, Łowicz, Sulejów, miasto i gmina Sieradz, } \\
\text { Działoszyn }\end{array}$ \\
\hline 1960 & 3 & miasto i gmina Sieradz, Sulejów \\
\hline 1962 & 1 & Poddębice \\
\hline 1963 & 1 & Uniejów \\
\hline 1965 & 3 & Działoszyn, miasto i gmina Sieradz \\
\hline 1966 & 1 & Sulejów \\
\hline 1979 & 3 & Uniejów, miasto i gmina Sieradz \\
\hline 1982 & 3 & miasto i gmina Tomaszów Mazowiecki, Działoszyn \\
\hline 1997 & 11 & $\begin{array}{l}\text { Burzenin, Działoszyn, Gidle, Pęczniew, Poddębice, Radomsko, } \\
\text { miasto i gmina Sieradz, Sulejów, Zapolice, Uniejów }\end{array}$ \\
\hline 1999 & 1 & Żytno \\
\hline 2001 & 9 & $\begin{array}{l}\text { Gidle, Inowłódz, Pęczniew, Poddębice, miasto i gmina } \\
\text { Tomaszów Mazowiecki, Uniejów, Zapolice, Żytno }\end{array}$ \\
\hline 2005 & 2 & miasto i gmina Tomaszów Mazowiecki \\
\hline 2010 & 19 & $\begin{array}{l}\text { Burzenin, Działoszyn, Gidle, Inowłódz, Kutno, Ładzice, } \\
\text { Łowicz, Pęczniew, Poddębice, gmina Radomsko, miasto } \\
\text { i gmina Sieradz, Sulejów, miasto i gmina Tomaszów } \\
\text { Mazowiecki, Uniejów, Warta, Zapolice, Żytno }\end{array}$ \\
\hline
\end{tabular}

Źródło: opracowanie własne na podstawie: Stachy i in. (1996); Wstępna ocena ryzyka powodziowego (2011); Plan operacyjny... (2013).

W tym okresie zarejestrowano występowanie powodzi przede wszystkim w gminach położonych w zlewni Warty. W Czarnocinie oraz Rozprzy nie odnotowano pojawienia się ,wodnego żywiołu” (rycina 2.5).

Powodzie wywołują negatywne skutki dla ludzi, środowiska, dziedzictwa kulturowego oraz działalności gospodarczej. W badanych gminach województwa łódzkiego powodzie przede wszystkim negatywnie oddziaływały na działalność gospodarczą (ok. 90\%) oraz środowisko (ok. 86\%) (rycina 2.6). 


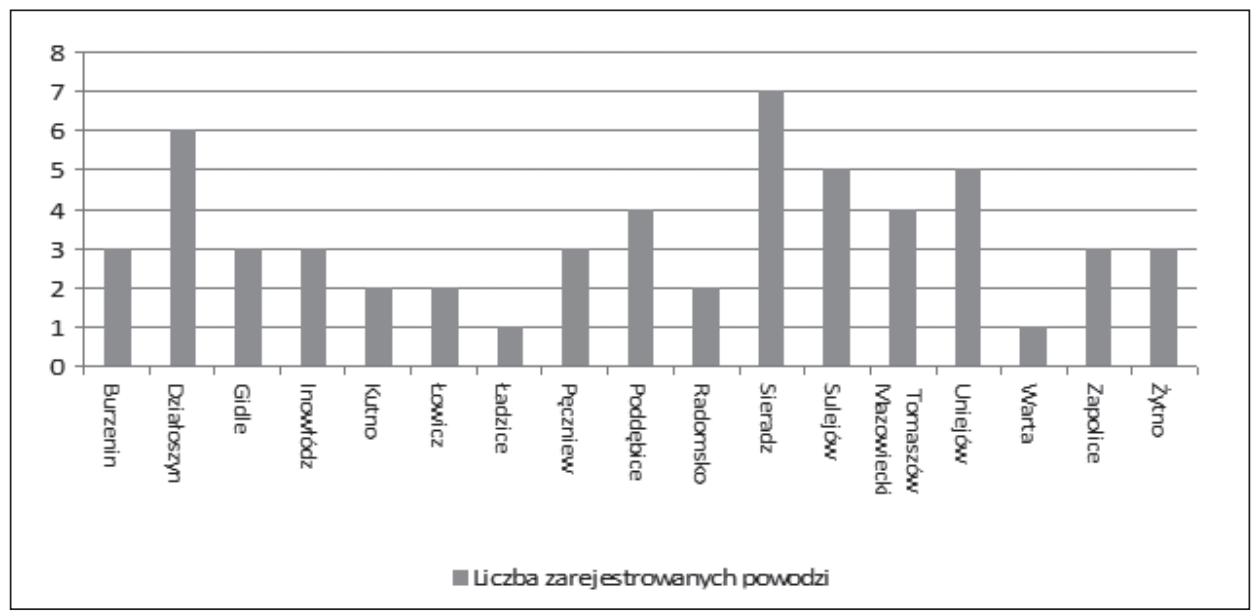

Rycina 2.5. Liczba powodzi zarejestrowanych w badanych gminach w latach 1947-2010 Źródło: opracowanie własne na podstawie: Stachy i in. (1996); Wstęna ocena... (2011);

Plan operacyjny... (2013)

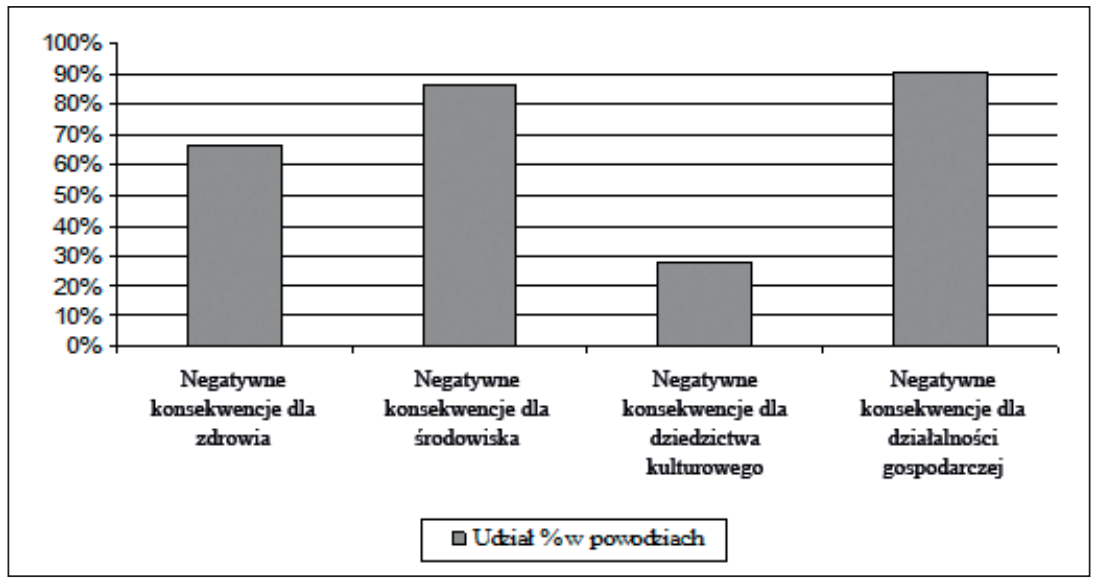

Rycina 2.6. Udział negatywnych konsekwencji dla zdrowia ludzi, środowiska, dziedzictwa kulturowego i działalności gospodarczej w powodziach w latach 1947-2010 w badanych gminach

Źródło: opracowanie własne na podstawie WORP, 2011

W gminach województwa łódzkiego o bardzo dużym i dużym wskaźniku ryzyka powodziowego najgroźniejsze w skutkach były powodzie z lat 2010, 1997, 1947, 2001. Największy obszar objęła powódź z 2010 r. oraz 1997 r. 


\section{UŻYTKOWANIE ZIEMI NA TERENACH ZAGROŻONYCH POWODZIAMI W GMINACH WOJEWÓDZTWA ŁÓDZKIEGO}

\subsection{Ogólna charakterystyka zagospodarowania}

Podstawową jednostką przyjętą do analizy był teren szczególnego zagrożenia powodzią. Największe pod względem powierzchni tereny wody 100-letniej (tabela 3.1) występują w gminach wiejskich lub miejsko-wiejskich, najmniejsze w gminach miejskich, nad mniejszymi rzekami lub tam, gdzie istnieją wały przeciwpowodziowe. W gminie Poddębice oraz Gidle udział terenów zalewowych w ogólnej powierzchni zalewu wszystkich gmin jest największy i wynosi ok. 14\%, natomiast w Kutnie oraz gminach Ładzice i Czarnocin tylko 1\%. Rozważając tę kwestię, znacznie ważniejszy jest jednak udział powierzchni terenów zagrożonych powodziami w stosunku do obszaru danej gminy. W szczególności w gminach miejskich i miejsko-wiejskich obszary narażone na niebezpieczeństwo powodzi stanowią znaczną część ich powierzchni, w związku z czym wprowadzenie całkowitego zakazu zabudowy na tych terenach doprowadziłoby do ograniczenia ich rozwoju. W gminie Gidle udział terenów zalewowych w powierzchni gminy wynosi ok. $40 \%$, w pozostałych gminach nie przekracza $20 \%$.

Na obszarach zagrożonych powodziami w gminach podlegających badaniu dominują tereny użytkowane rolniczo, zajmują ok. $62 \%$ powierzchni zalewu, tereny wód $-20 \%$, lasy $-16 \%$. W przypadku pozostałych form użytkowania terenu, ich udział nie przekracza $1 \%$, z czego największa powierzchnia zajęta jest pod tereny mieszkaniowe $-0,87 \%$ (przede wszystkim zabudowy jednorodzinnej). Na obszarach miejskich $w$ granicach terenów zalewowych największy udział mają tereny rolne $-68,58 \%$, lasy $-14,39 \%$, obszary wód $-4,54 \%$. Wśród terenów antropogenicznych dominują tereny zabudowy techniczno-produkcyjnej-2,49\%, mieszkaniowej $-2,45 \%$ oraz infrastruktury technicznej $-2,39 \%$. Na obszarach gmin miejsko-wiejskich tereny rolne stanowią 58,3\% terenów zalewowych, tereny wód $-22,67 \%$, lasy $-17,24 \%$. Tereny zabudowane zajmują $1,2 \%$, z czego najwięcej jest terenów mieszkaniowych $-0,6 \%$. W granicach terenów zalewowych obszarów wiejskich dominują tereny rolne $-62,58 \%$, tereny wód $-21 \%$ oraz lasy $-15,02 \%$. 
Tabela 3.1. Wielkość obszarów szczególnego zagrożenia powodzią w badanych gminach województwa łódzkiego

\begin{tabular}{|c|c|c|c|}
\hline \multirow[b]{2}{*}{ Zlewnia } & \multirow[b]{2}{*}{ Gminy } & \multicolumn{2}{|c|}{ Tereny szczególnego zagrożenia powodzią } \\
\hline & & $\begin{array}{l}\text { powierzchnia } \\
\text { ogółem (ha) }\end{array}$ & $\begin{array}{l}\text { udział terenów szczególnego zagrożenia } \\
\text { powodzią w gminie w stosunku } \\
\text { do ich powierzchni ogółem }(\%)\end{array}$ \\
\hline \multirow{12}{*}{ Warty } & Gidle & 3625,09 & 39,27 \\
\hline & Radomsko & 1242,42 & 14,61 \\
\hline & Ładzice & 189,45 & 2,29 \\
\hline & Działoszyn & 726,09 & 6,05 \\
\hline & Burzenin & 690,68 & 5,84 \\
\hline & Zapolice & 953,63 & 11,79 \\
\hline & Sieradz (gmina wiejska) & 2513,11 & 13,83 \\
\hline & Sieradz (miasto) & 740,17 & 14,44 \\
\hline & Warta & 1919,37 & 7,6 \\
\hline & Pęczniew & 2278,94 & 17,97 \\
\hline & Poddębice & 3671,87 & 16,4 \\
\hline & Uniejów & 729,42 & 6,07 \\
\hline \multirow{7}{*}{ Pilicy } & Żytno & 969,48 & 5,19 \\
\hline & Rozprza & 902,27 & 5,53 \\
\hline & Sulejów & 1022,29 & 5,43 \\
\hline & Czarnocin & 321,67 & 4,49 \\
\hline & $\begin{array}{l}\text { Tomaszów Mazowiecki } \\
\text { (gmina wiejska) }\end{array}$ & 1583,8 & 10,47 \\
\hline & $\begin{array}{l}\text { Tomaszów Mazowiecki } \\
\text { (miasto) }\end{array}$ & 761,59 & 18,33 \\
\hline & Inowłódz & 828,40 & 8,49 \\
\hline \multirow{2}{*}{ Bzury } & Kutno & 292,6 & 8,59 \\
\hline & Łowicz & 396,24 & 16,91 \\
\hline \multicolumn{2}{|l|}{ Suma } & 26358,57 & - \\
\hline
\end{tabular}

Źródło: opracowanie własne na podstawie danych RZGW w Poznaniu i Warszawie oraz BPPWŁ, 2012.

Tereny antropogeniczne zajmują, tak jak w przypadku gmin miejsko-wiejskich, nieznaczny udział, z czego dominuje zabudowa mieszkaniowa $-0,82 \%$.

Następnie analizie poddano poszczególne formy użytkowania terenu we wszystkich gminach, w granicach terenów zalewowych. Tereny użytkowane rolniczo dominują w gminie Poddębice, gdzie zajmują 87\% terenów zagrożonych powodziami. 


\begin{tabular}{|c|c|c|c|c|c|c|c|c|c|c|c|c|}
\hline 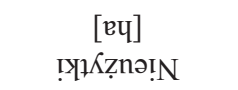 & oे. & $\frac{9}{0}$ & I & $\stackrel{\infty}{=}$ & 1 & 1 & $\begin{array}{l}8 \\
0 \\
0\end{array}$ & $\stackrel{\text { nे }}{\tilde{0}}$ & I & 1 & 1 & $\frac{2}{0}$ \\
\hline 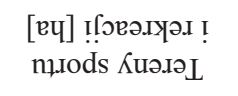 & $\begin{array}{l}0 \\
\text { ñ } \\
0\end{array}$ & $\begin{array}{l}\text { मे } \\
\text { i }\end{array}$ & $\begin{array}{l}\tilde{1} \\
0\end{array}$ & $\begin{array}{l}0 \\
0 \\
0\end{array}$ & $\stackrel{+}{\frac{\pi}{m}}$ & $\hat{n}$ & $\mathfrak{n}^{\infty}$ & $\underbrace{\infty}_{0}$ & 1 & 1 & $\begin{array}{l}\stackrel{ \pm}{\sim} \\
\stackrel{二}{2}\end{array}$ & $\tilde{n}^{n}$ \\
\hline 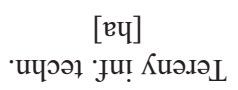 & $\stackrel{\sim}{\overbrace{0}}$ & $\stackrel{1}{0}$ & $\begin{array}{l}+ \\
0 \\
0\end{array}$ & $\stackrel{\overbrace{}}{-}$ & 1 & I & 1 & $\frac{2}{0}$ & $\vec{n}$ & $\stackrel{5}{\rightarrow}$ & $\stackrel{0}{?}$ & I \\
\hline 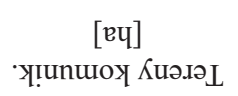 & 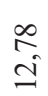 & \& & 1 & $\begin{array}{l}\hat{b} \\
i\end{array}$ & Oे. & 1 & $=$ & $\begin{array}{l}\infty \\
\sim \\
i\end{array}$ & $\ddot{n}$ & in & $\frac{m}{i}$ & $\tilde{n}$ \\
\hline $\begin{array}{c}{[\mathrm{\varepsilon ч}]} \\
\text { pọ КчәәәЈ }\end{array}$ & $\frac{n}{6}$ & ñ & $\hat{\bar{a}}$ & $\frac{1}{n}$ & 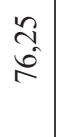 & $\vec{\sigma}$ & $\begin{array}{l}0 \\
0 \\
0\end{array}$ & $\begin{array}{l}\infty \\
\infty \\
0 \\
+\end{array}$ & $\begin{array}{l}\infty \\
\infty \\
i \\
\\
-\end{array}$ & $\frac{n}{2}$ & 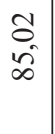 & $\begin{array}{l}\stackrel{n}{+} \\
\infty \\
\infty\end{array}$ \\
\hline 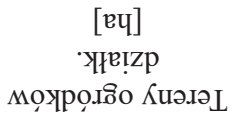 & I & 1 & 1 & 1 & 1 & 1 & 1 & $\underset{\infty}{\vec{\sigma}_{0}}$ & 1 & 1 & 1 & 1 \\
\hline 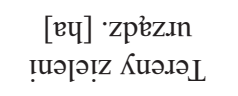 & I & I & I & $\underset{i}{i}$ & 1 & I & ָ̃ & $\begin{array}{l}\hat{0} \\
\text { in }\end{array}$ & $\frac{ \pm}{0}$ & 1 & $\hat{\sigma}$ & $\frac{\infty}{\infty}$ \\
\hline $\begin{array}{l}{[\mathrm{eq}]} \\
\text { KseT }\end{array}$ & $\begin{array}{l}\text { fa } \\
\text { gे }\end{array}$ & $\begin{array}{l}\stackrel{2}{i} \\
\hat{D} \\
i\end{array}$ & $\underset{\infty}{\infty}$ & 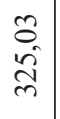 & $\frac{n}{a}$ & $\begin{array}{l}\stackrel{+}{N} \\
\infty \\
\stackrel{\sim}{2}\end{array}$ & 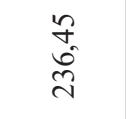 & $\stackrel{n}{8}$ & $\begin{array}{l}2 \\
\text { ôे } \\
0 \\
0\end{array}$ & $\begin{array}{l}\vec{\infty} \\
\dot{+}\end{array}$ & $\begin{array}{l}\text { aे } \\
\text { ָे }\end{array}$ & $\frac{n}{2}$ \\
\hline 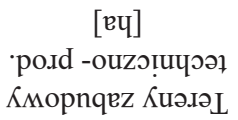 & $\underset{\text { s. }}{\text { r. }}$ & 1 & $\hat{n}$ & m. & $\begin{array}{c}0 \\
\text { ñ } \\
0\end{array}$ & 1 & $\frac{ \pm}{0}$ & $\overrightarrow{0}$ & 1 & 1 & $\underset{-}{\approx}$ & $\begin{array}{l}n \\
\tilde{n}\end{array}$ \\
\hline 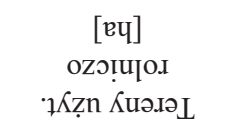 & $\begin{array}{l}m \\
\alpha \\
\infty \\
\delta \\
m\end{array}$ & 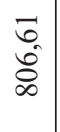 & $\frac{2}{\infty}$ & 昰 & $\begin{array}{l}2 \\
\stackrel{2}{\infty} \\
\text { n. }\end{array}$ & $\underset{\stackrel{F}{f}}{\stackrel{\vec{\sigma}}{\sigma}}$ & $\begin{array}{l}\vec{n} \\
\hat{\sigma} \\
\vec{n}\end{array}$ & $\stackrel{\infty}{n}$ & ले & $\begin{array}{l}\hat{a} \\
\infty \\
\infty \\
\text { N }\end{array}$ & 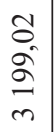 & $\begin{array}{l}\text { N } \\
\text { in }\end{array}$ \\
\hline 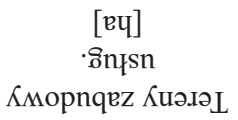 & $\overrightarrow{\widehat{\sigma}}$ & $\bar{\sigma}$ & 1 & $\stackrel{0}{6}$ & 1 & 1 & 1 & fr & 1 & $\underset{\sim}{\mathbb{f}}$ & $\frac{\infty}{\sigma}$ & $\begin{array}{l}\stackrel{g}{+} \\
\dot{\sigma}\end{array}$ \\
\hline 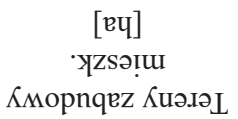 & 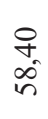 & 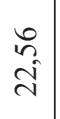 & $\hat{\sigma}$ & $\stackrel{n}{=}$ & $\stackrel{0}{n}$ & . & $\underset{6}{0}$ & $\underset{⿱}{\stackrel{J}{*}}$ & . & $\stackrel{\text { ஸे }}{\infty}$ & $\begin{array}{l}\text { : } \\
\text { in }\end{array}$ & fi \\
\hline Кய!щщ & $\frac{\stackrel{0}{\sigma}}{\mathfrak{\sigma}}$ & 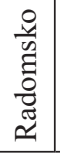 & 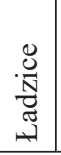 & 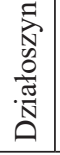 & 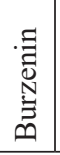 & 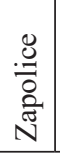 & 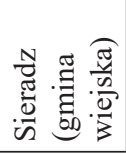 & 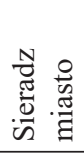 & 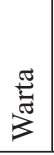 & 总 & $\begin{array}{l}.00 \\
\frac{0}{0} \\
\frac{0}{0} \\
0\end{array}$ & : \\
\hline в!ฺмәZ & \multicolumn{12}{|c|}{ 离 } \\
\hline
\end{tabular}




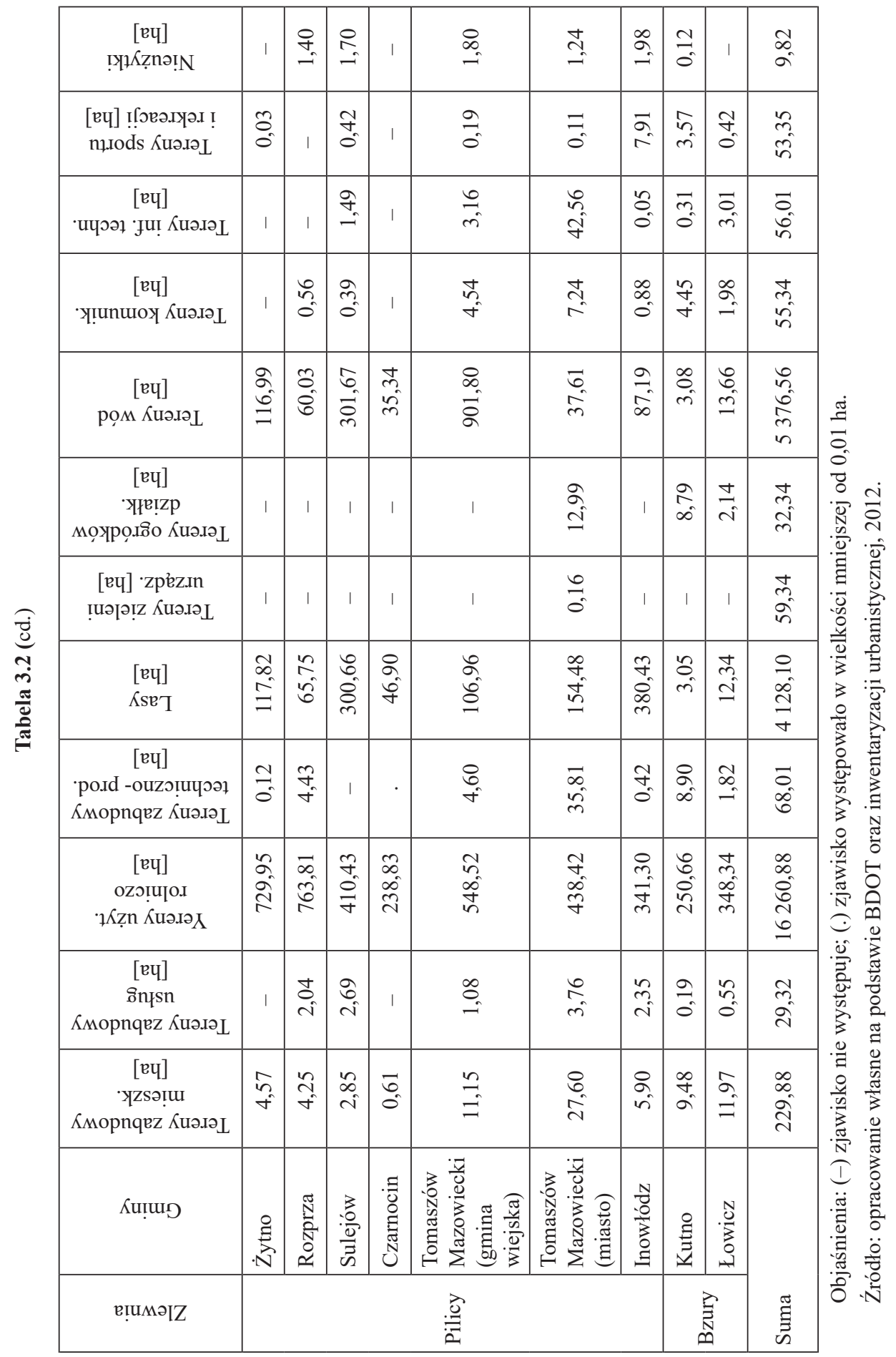


W gminie Pęczniew oraz Warta dominują tereny wód, co jest związane z istnieniem zbiornika Jeziorsko (zajmują odpowiednio 83\% i 65\% terenów zagrożonych powodziami). Największa powierzchnia terenów zabudowy techniczno-produkcyjnej, infrastruktury technicznej oraz ogródków działkowych została zinwentaryzowana na obszarze Tomaszowa Mazowieckiego, które pod względem sposobu użytkowania terenów szczególnego zagrożenia powodzią znacznie różni się od pozostałych gmin. Powyżej miasta znajduje się zbiornik Sulejów, który wywołuje poczucie bezpieczeństwa wśród użytkowników terenów zalewowych i skutkuje ich zabudową. W Uniejowie występuje największa powierzchnia terenów usługowych, co również związane jest z istnieniem zbiornika wodnego powyżej gminy (Jeziorsko). W Gidlach zinwentaryzowano największą powierzchnię terenów mieszkaniowych i powiązanych z nimi terenów komunikacji (co jest związane $\mathrm{z}$ udziałem terenów zalewowych w powierzchni gminy - 40\%) (tabela 3.2) oraz lasów.

Zabudowa na obszarze zalewowym występuje w szczególności w gminach miejskich, na obszarach nieobwałowanych, w dolinach mniejszych rzek oraz w gminach, w których udział terenów zagrożonych powodziami w powierzchni całej gminy jest duży. Rzeka Warta posiada szeroką równinę zalewową w miejscach niechronionych wałami, co sprzyja zagospodarowaniu, jednak ma to negatywne konsekwencje w przypadku wystąpienia powodzi. Mniejsze rzeki, jak Czarna (na obszarze Tomaszowa Mazowieckiego), stwarzają większe poczucie bezpieczeństwa, dlatego też dna ich dolin są często wykorzystywane pod zabudowę.

\subsection{Zróżnicowanie badanych gmin pod względem struktury użytkowania ziemi}

W granicach terenów zagrożonych powodziami, w badanych gminach obliczono wskaźnik poziomej intensywności użytkowania, wykorzystania powierzchni oraz terenów wolnych od zabudowy. Jest to niezwykle ważne zagadnienie, gdyż wraz ze wzrostem terenów zabudowanych, wzrasta ryzyko powodziowe na danym obszarze.

Wskaźnik poziomej intensywności użytkowania na obszarach szczególnego zagrożenia powodziami określono za pomocą wzoru:

$$
J=F_{z} F_{c}^{*} 100,
$$

gdzie:

$J$ - wskaźnik poziomej intensywności użytkowania;

$F_{z}$ - powierzchnia terenów zabudowanych $\left[\mathrm{m}^{2}\right]$;

$F_{c}$ - powierzchnia obszarów szczególnego zagrożenia powodzią $\left[\mathrm{m}^{2}\right]$. 
Wiadomo, że im wyższe wartości wskaźnika, tym większe jest potencjalne negatywne oddziaływanie powodzi na ludzi, działalność gospodarczą, środowisko, dziedzictwo kulturowe. Wskutek uszczelniania powierzchni (poprzez jej zabudowę) następuje ograniczenie możliwości infiltracji wody do gruntu, zwiększa się tym samym objętość odpływu (Ripl 1995; Sanders, Phillipson 2003). Pozioma intensywność zagospodarowania w granicach wody 100-letniej, w gminach

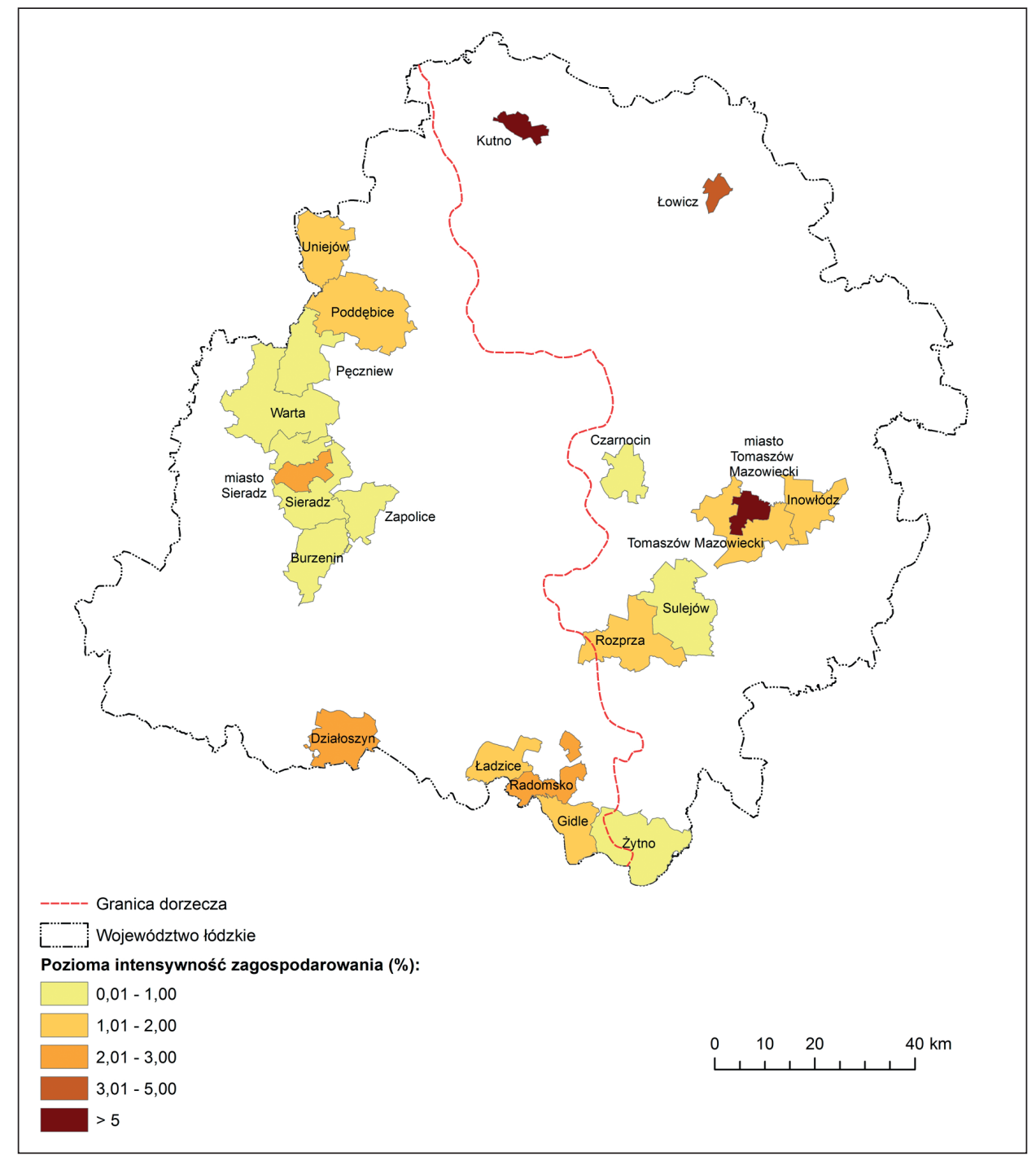

Rycina 3.1. Wskaźnik poziomej intensywności zagospodarowania na obszarach zagrożonych powodziami w badanych gminach województwa łódzkiego

Źródło: opracowanie własne, 2013 
miejskich wynosi $8 \%$, natomiast w gminach miejsko-wiejskich i wiejskich ok. $1 \%$ (rycina 3.1). W przypadku Tomaszowa Mazowieckiego ok. 14\% terenów zagrożonych powodziami zajętych jest pod zabudowę, głównie techniczno-produkcyjną, w Kutnie 7,5\%, w Łowiczu 4,5\%. W pozostałych gminach wskaźnik ten nie przekracza 3\%: Działoszyn 2,8\%, Sieradz (miasto) 2,4\%, Radomsko 2,1\%, Inowłódz $2 \%$, Uniejów 1,9\%, Gidle 1,8\%, Poddębice 1,5\%, Tomaszów Mazowiecki (gmina wiejska) $1,3 \%$, Rozprza $1,2 \%$, Ładzice $1 \%$, Burzenin $0,8 \%$, Sulejów $0,7 \%$, Żytno 0,5\%, Pęczniew 0,5\%, Sieradz (gmina wiejska) 0,3\%, Czarnocin 0,2\%, Zapolice $0,03 \%$, Warta $0,02 \%$. Najniższe wartości wskaźnika poziomej intensywności zagospodarowania w granicach wody 100-letniej uzyskały gminy, w których istnieją wały przeciwpowodziowe. W strefie międzywala zabudowa nie powstaje, istnieją od tego jednak pewne wyjątki, czego przykładem jest Uniejów. Tereny zalewowe w mieście zostały zagospodarowane pod lecznictwo uzdrowiskowe oraz funkcje rekreacyjno-sportowe. Powstały tu Termy Uniejów z restauracjami, pływalnią otwartą kompleksu termalno-basenowego, zespołem boisk do piłki nożnej, siatkówki, piłki plażowej, kortów tenisowych, plażą miejską oraz kąpieliskiem strzeżonym, Instytutem Zdrowia Człowieka, Kasztelem Rycerskim. Część zdrojowa rozwija się w oparciu o walory przyrodnicze, zgodę na zabudowę terenu międzywala wydał dyrektor Regionalnego Zarządu Gospodarki Wodnej w Poznaniu.

Wskaźnik wykorzystania powierzchni na obszarach szczególnego zagrożenia powodzią określono za pomocą wzoru:

$$
W=\left(F_{z}+F_{k}\right) / F_{c} * 100,
$$

gdzie:

$W$ - wskaźnik wykorzystania powierzchni;

$F_{z}$ - powierzchnia terenów zabudowanych $\left[\mathrm{m}^{2}\right]$;

$F_{k}$ - powierzchnia terenów komunikacyjnych $\left[\mathrm{m}^{2}\right]$;

$F_{c}$ - powierzchnia obszarów szczególnego zagrożenia powodzią $\left[\mathrm{m}^{2}\right]$.

Wskaźnik $W$ informuje o stopniu wykorzystania powierzchni terenów szczególnego zagrożenia powodzią. W gminach miejskich wskaźnik ten wynosi 9,3\%, w gminach wiejskich $-1,33 \%$, natomiast miejsko-wiejskich ok. 1,28\%. W grupie badanych gmin 5 uzyskało wskaźnik powyżej 3\%, gdyż poza Tomaszowem Mazowieckim (15,3\%), Kutnem (9,2\%), Łowiczem (ok. 5\%), również Działoszyn (ok. 3,2\%) i Sieradz (ok. 3,1\%) cechuje wysoki stopień zainwestowania. W pozostałych gminach wskaźnik wykorzystania powierzchni nie przekraczał 3\%: Radomsko 2,8\%, Gidle 2,2\%, Inowłódz 2,1\%, Uniejów 2\%, Poddębice 1,6\%, Tomaszów Mazowiecki (gmina wiejska) 1,6\%, Rozprza 1,25\%, Ładzice 1\%, Burzenin 0,9\%, Sulejów 0,8\%, Pęczniew 0,6\%, Żytno 0,5\%, Sieradz (gmina wiejska) 0,3\%, Czarnocin $0,2 \%$, Warta $0,05 \%$, Zapolice $0,03 \%$. Stanowi to potencjalne zagrożenie w przypadku wystąpienia powodzi, gdyż znacznie utrudniona jest wówczas infiltracja wody oraz generowane są straty (rycina 3.2) (Rudnik 2012). 
Wskaźnik terenów wolnych od zabudowy w badanych gminach na obszarach szczególnego zagrożenia powodzią określono za pomocą wzoru:

$$
B=F_{b} / F_{c} * 100,
$$

gdzie:

$B$ - wskaźnik powierzchni wolnej od zabudowy;

$F_{b}$ - powierzchnia wolna od zabudowy $\left[\mathrm{m}^{2}\right]$;

$F_{c}$ - powierzchnia całkowita terenu szczególnego zagrożenia powodzią $\left[\mathrm{m}^{2}\right]$.

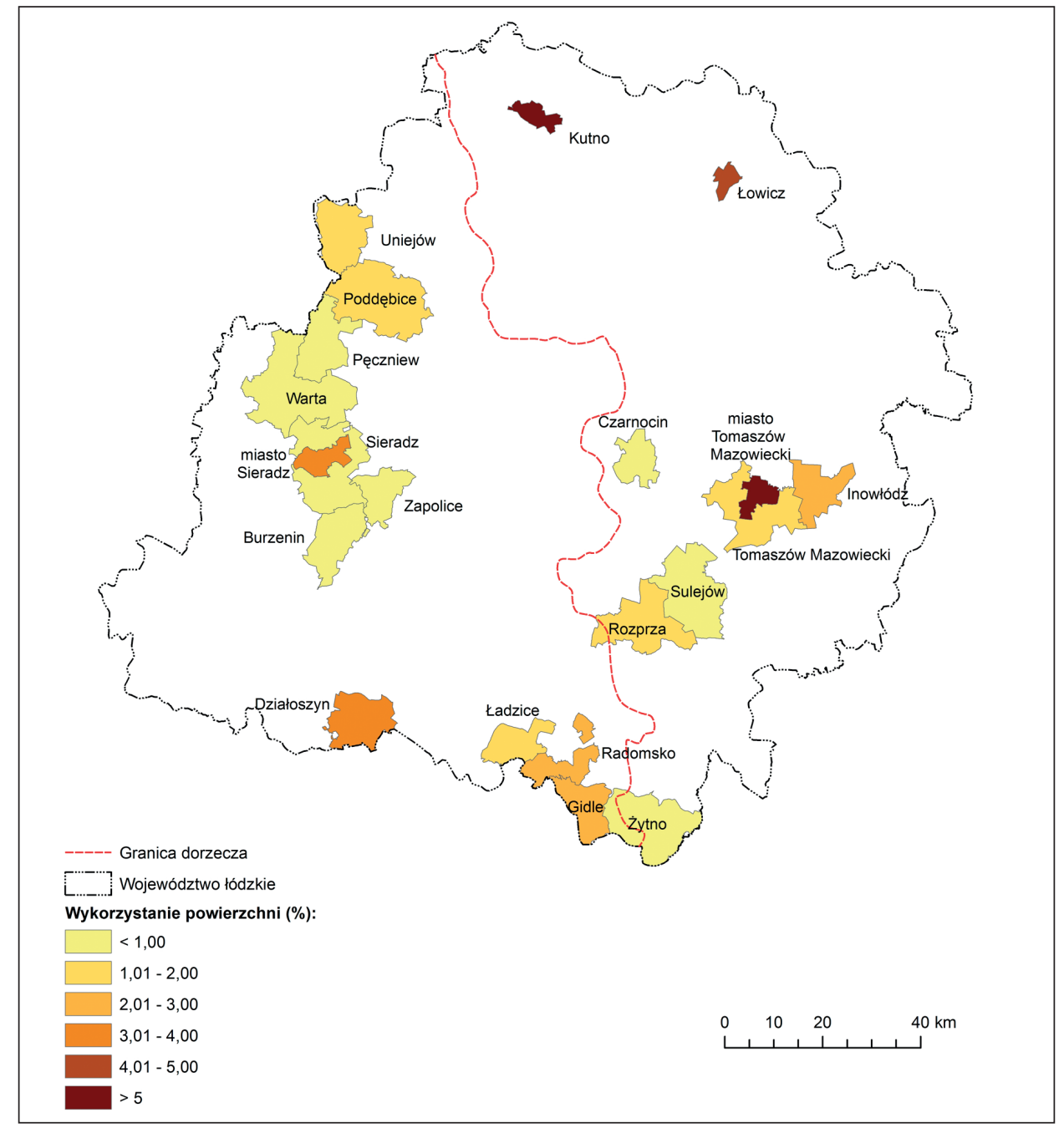

Rycina 3.2. Wskaźnik wykorzystania powierzchni na obszarach zagrożonych powodziami w badanych gminach województwa łódzkiego

Źródło: opracowanie własne, 2013 
Największy udział terenów wolnych od zabudowy w granicach zalewu jest w gminach wiejskich i miejsko-wiejskich - ok. 98-99\%, w gminach miejskich natomiast wynosi on ok. $90-91 \%$. Z punktu widzenia ochrony przed powodzią najkorzystniejsza sytuacja jest w Burzeninie, Zapolicach, Sieradzu (gminie wiejskiej), Warcie, Pęczniewie, Żytnie, Sulejowie, Czarnocinie (rycina 3.3), gdzie udział terenów wolnych od zabudowy to ponad 99\%. Wynika to głównie z istnienia na obszarze tych gmin wałów przeciwpowodziowych. Wskutek tego dochodzi do podziału równiny zalewowej. W strefie międzywala zabudowa nie powstaje.

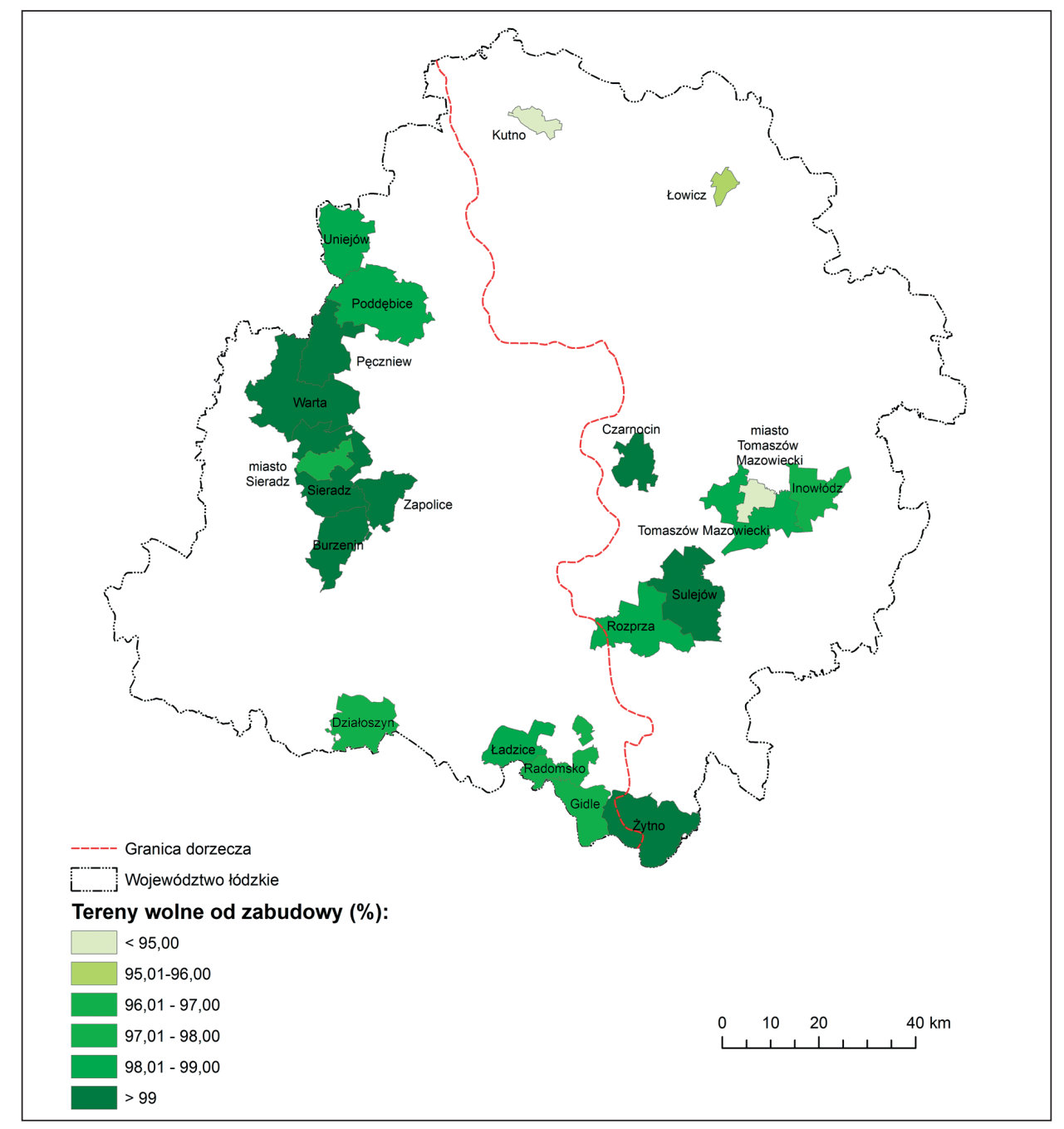

Rycina 3.3. Wskaźnik terenów wolnych od zabudowy na obszarach zagrożonych powodziami w badanych gminach województwa łódzkiego Źródło: opracowanie własne, 2013 
Analizie poddano również rodzaj zabudowy dominującej wśród terenów zabudowanych oraz typy terenów wolnych od zabudowy. W grupie obszarów wolnych od zabudowy wyodrębniono tereny: rolne, zieleni (tereny leśne oraz zieleni urządzonej) oraz wód i nieużytki ${ }^{1}$. Na rycinie 3.4 przedstawiono strukturę użytkowania terenów wolnych od zabudowy dla obszarów szczególnego zagrożenia powodzią w wybranych do badania gminach województwa łódzkiego. Bliskie sąsiedztwo punktów na rycinie 3.4 świadczy o istnieniu podobieństwa badanych jednostek pod tym względem.

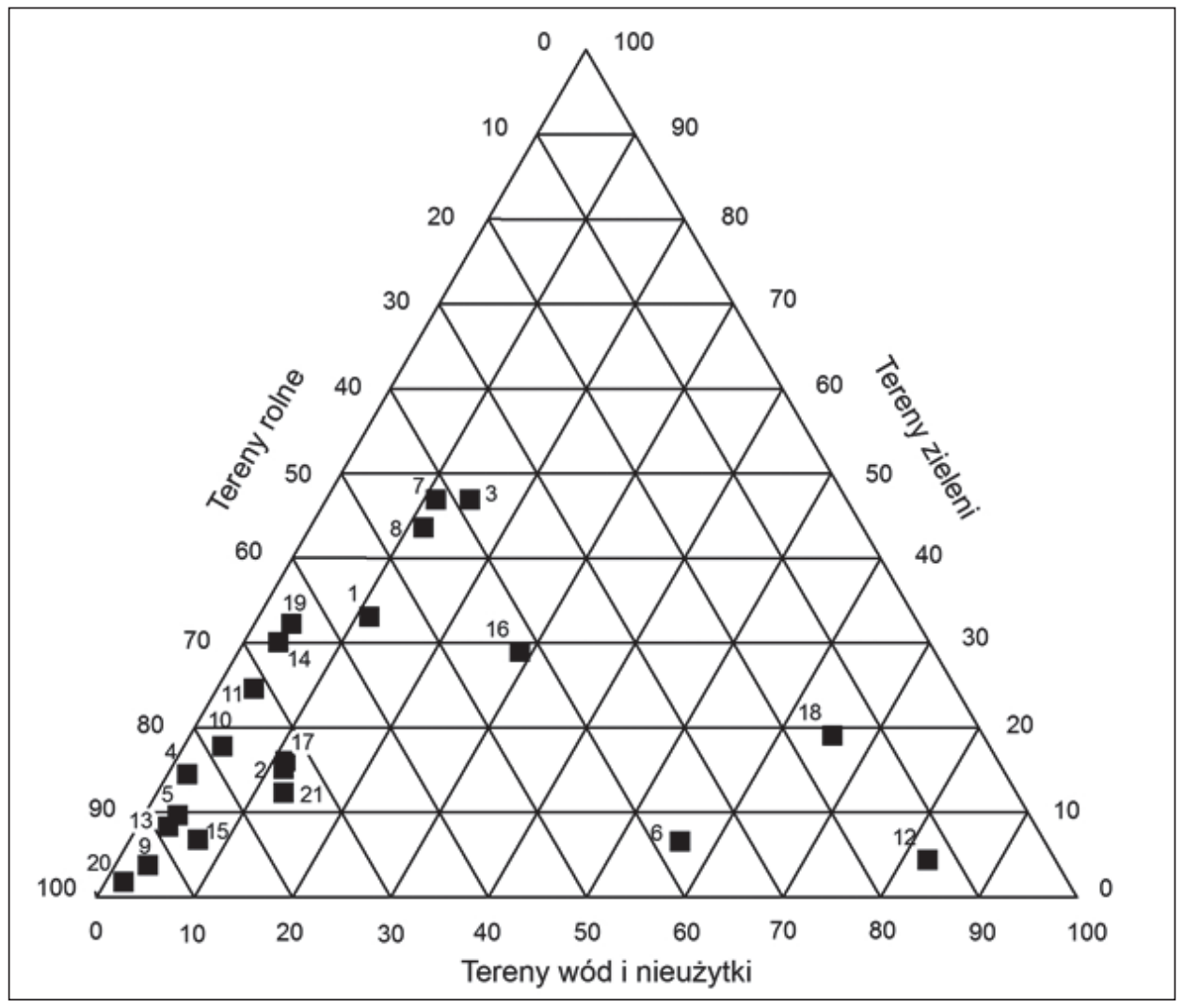

Rycina 3.4. Zróżnicowanie terenów zagrożonych powodziami pod względem struktury użytkowania terenów wolnych od zabudowy

1 - Burzenin, 2 - Czarnocin, 3 - Działoszyn, 4 - Gidle, 5 - Sieradz (gmina wiejska), 6 - Tomaszów Mazowiecki (gmina wiejska), 7 - Inowłódz, 8 - Ładzice, 9 - Łowicz, 10 -Sieradz (miasto), 11 - Tomaszów Mazowiecki (miasto), 12 - Pęczniew, 13 - Poddębice, 14 - Radomsko, 15 - Rozprza, 16 - Sulejów, 17 - Uniejów, 18 - Warta, 19 - Zapolice, 20 - Kutno, 21 - Żytno Źródło: opracowanie własne, 2013

1 Nieużytki włączono do terenów wód, ze względu na znikomą powierzchnię, jaką zajmowały. 
Analiza trójkąta Ossana pokazuje, że wśród terenów wolnych od zabudowy dominuje użytkowanie rolne, które w przypadku wystąpienia powodzi generuje straty m.in. w uprawach. Ma to również bardzo duże znaczenie w procesie infiltracji wody, gdyż na polach proces ten jest znacznie mniejszy niż w przypadku np. terenów leśnych, ze względu na bardzo dużą przepuszczalność gleb leśnych (Klimaszewski 1994). Tereny zieleni, choć nie generują takich strat, jak grunty orne, to jednak mają wpływ na hydrauliczne warunki przepływu wody: powodują zwiększenie oporów przepływu wody, zmniejszenie prędkości jej przepływu i wzrost napełnienia, a więc zmniejszają przepustowość koryta. Niekontrolowany rozwój roślinności na obszarze międzywala doprowadza do podpiętrzenia przepływających wód wielkich i w efekcie może zagrażać zalaniem terenów przyległych. Dlatego też niezbędne jest usuwanie z obszarów zalewowych rzek roślinności, która stanowi największe utrudnienie w odprowadzaniu wód wielkich. Największy wpływ na zmniejszenie przepustowości ma roślinność, która rośnie wzdłuż brzegów koryta głównego. Szerokość pasa równiny zalewowej niepokrytej roślinnością nie powinna być mniejsza niż połowa szerokości koryta głównego. Skupiska roślinności w tej części terenu zagrożonego powodziami mogą doprowadzić do znacznego spiętrzenia wody, zmniejszenia prędkości jej przepływu, wskutek czego dochodzi do wzmożonej akumulacji rumowiska wleczonego w skupiskach terenów zieleni i tuż za nimi. Można natomiast dopuścić do występowania rzadkich skupisk roślinności wysokiej na obszarze zalewowym wzdłuż brzegu rzeki. Należy jednak dbać o to, by pomiędzy drzewami nie wyrosły zarośla i krzewy. Ponadto w wyjątkowych sytuacjach, np. na obszarach zurbanizowanych, można dopuścić do pozostawienia rzędu rzadkich dojrzałych wiklin lub wierzb wzdłuż linii brzegu koryta głównego (Kubrak i in. 2014).

W związku ze zróżnicowaniem struktury omawianych terenów wydzielono 4 grupy gmin, ze względu na dominujący typ obszarów wolnych od zabudowy, na terenach zalewowych:

1) tereny rolne zajmujące $>50 \%$ powierzchni obszarów wolnych od zabudowy (14 gmin);

2) tereny wód zajmujące $>50 \%$ powierzchni obszarów wolnych od zabudowy (3 gminy);

3) tereny rolno-zielone charakteryzujące się znaczącym udziałem ok. $40 \%$ zarówno obszarów zieleni, jak i rolnych (3 gminy);

4) tereny wodno-zielono-rolne charakteryzujące się dużym udziałem ok. 30\% zarówno obszarów wód, zielonych, jak i rolnych (1 gmina).

Na rycinie 3.5 przedstawione zostały wyodrębnione typy gmin, ze względu na strukturę użytkowania terenów wolnych od zabudowy. Na analizowanych obszarach dominują tereny rolne (w grupie terenów niezabudowanych), ich największy udział przypada na Kutno oraz Lowicz i wynosi odpowiednio 97,6\% oraz $93 \%$. W czterech gminach tereny rolne zajmują od $80 \%$ do $90 \%$ terenów 
wolnych od zabudowy (Poddębice - 88,5\%, Sieradz - 86,3\%, Rozprza - 85,7\% i Gidle $-84,8 \%$ ). W granicach terenów zalewowych gmin: Sieradz (miasta), Żytno, Czarnocin i Uniejów tereny rolne stanowią odpowiednio: 76,7\%, 75,7\%, $74,4 \%$ i 73,8\% terenów niezainwestowanych. W trzech gminach ich udział wynosi od $60 \%$ do $70 \%$ (miasto Tomaszów Mazowiecki - 69,9\%, Radomsko - 66,8\%,

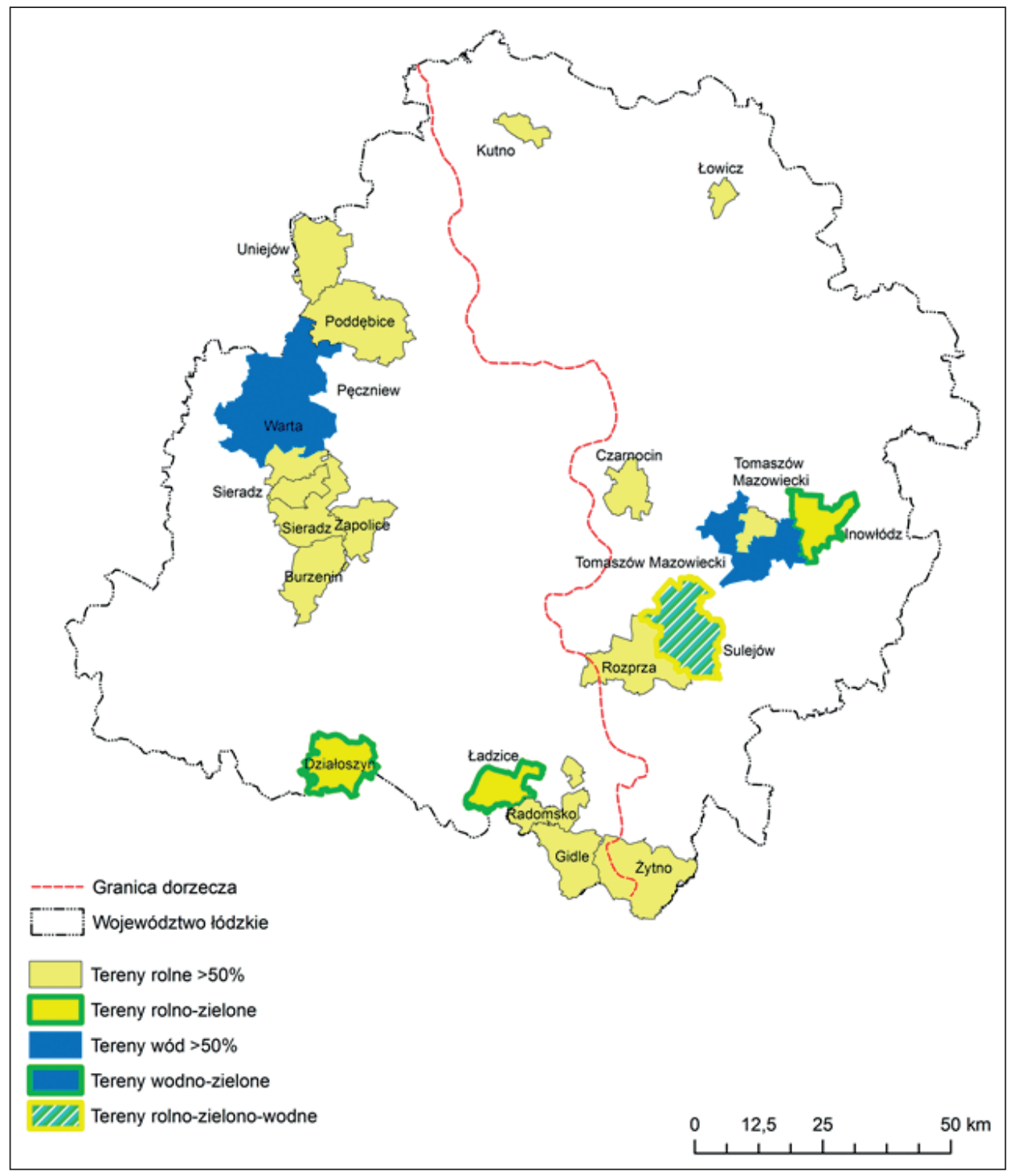

Rycina 3.5. Typy terenów wolnych od zabudowy na obszarach zagrożonych powodziami w badanych gminach województwa łódzkiego Źródło: opracowanie własne, 2013 
Zapolice - 64,14\%). W Burzeninie tereny rolne zajmują 56,8\% terenów wolnych od zabudowy na badanym obszarze.

W gminach: Pęczniew, Warta oraz Tomaszów Mazowiecki w granicach terenu wody $1 \%$ dominują obszary wód (zbiornik Jeziorsko na Warcie i Sulejów na Pilicy), stanowiąc odpowiednio $84 \%, 65 \%, 58 \%$ terenów wolnych od zabudowy.

$\mathrm{W}$ trzech gminach na obszarach zagrożonych powodziami $\mathrm{w}$ grupie terenów wolnych od zabudowy występuje podobny udział terenów rolnych i zieleni. W Działoszynie 46,5\% zajmują obszary pokryte roślinnością (ponad 99\% to lasy), natomiast tereny rolne $38,5 \%$ (z czego $74 \%$ - łąki, $26 \%$ - grunty orne). W granicach powierzchni zalewu gminy Inowłódz tereny niezainwestowane stanowią $97,89 \%$, z czego $47 \%$ to tereny zieleni (lasy), a $42 \%$ - rolne (96\% - łąki i pastwiska, $4 \%$ - grunty orne). Na obszarze zagrożonym powodzią $\mathrm{w}$ gminie Ładzice również nie da się wyodrębnić jednego, dominującego typu terenów wolnych od zabudowy: $44,7 \%$ to tereny rolne (łąki $-88,5 \%$, grunty orne $-11 \%$, sady $-0,5 \%$ ), $43,6 \%$ - tereny zieleni (lasy).

Struktura terenów wolnych od zabudowy w granicach wody $1 \%$ w Sulejowie znacznie różni się od pozostałych gmin, gdyż udział wszystkich wydzielonych form pokrycia terenu jest podobny: $40 \%$ to tereny rolne, natomiast na tereny zieleni i wód przypada po $30 \%$.

Obszary zabudowane podzielono również na trzy grupy:

- tereny mieszkaniowe;

- tereny usługowe;

- tereny techniczno-produkcyjne (do tej grupy zaliczono zarówno obiekty produkcyjne, jak i infrastruktury technicznej).

Wyniki klasyfikacji przedstawiono na trójkącie Ossana (rycina 3.6).

$\mathrm{Z}$ analizy terenów zabudowanych wynika, iż najczęściej na obszarach szczególnego zagrożenia powodzią występują tereny mieszkaniowe. Niestety wzrost terenów zabudowanych skutkuje mniejszą infiltracją oraz większym spływem powierzchniowym. Na obszarach silnie zurbanizowanych ponad połowa wody z deszczów odpływa, również do rzek, powodując wyższe stany wody. W związku ze zwiększonym odpływem niezbędna jest większa skuteczność infrastruktury przeciwpowodziowej (CA WALUP 2009).

Ze względu na funkcje zabudowy występującej na analizowanych obszarach, wydzielono 5 grup gmin, w których wśród terenów antropogenicznych dominują:

1) tereny mieszkaniowe $>50 \%$ ogółu obszarów zabudowanych (9 gmin);

2) tereny usługowe $>50 \%$ ogółu obszarów zabudowanych (6 gmin);

3) tereny techniczno-produkcyjne $>50 \%$ ogółu obszarów zabudowanych (3 gminy);

4) tereny usługowo-mieszkaniowe, znaczący udział po ok. 40\% obszarów zabudowy mieszkaniowej oraz usługowej (1 gmina);

5) tereny mieszkaniowo-produkcyjne, znaczący udział po ok. $40 \%$ zabudowy zarówno mieszkaniowej, jak i produkcyjnej (2 gminy) (rycina 3.7). 


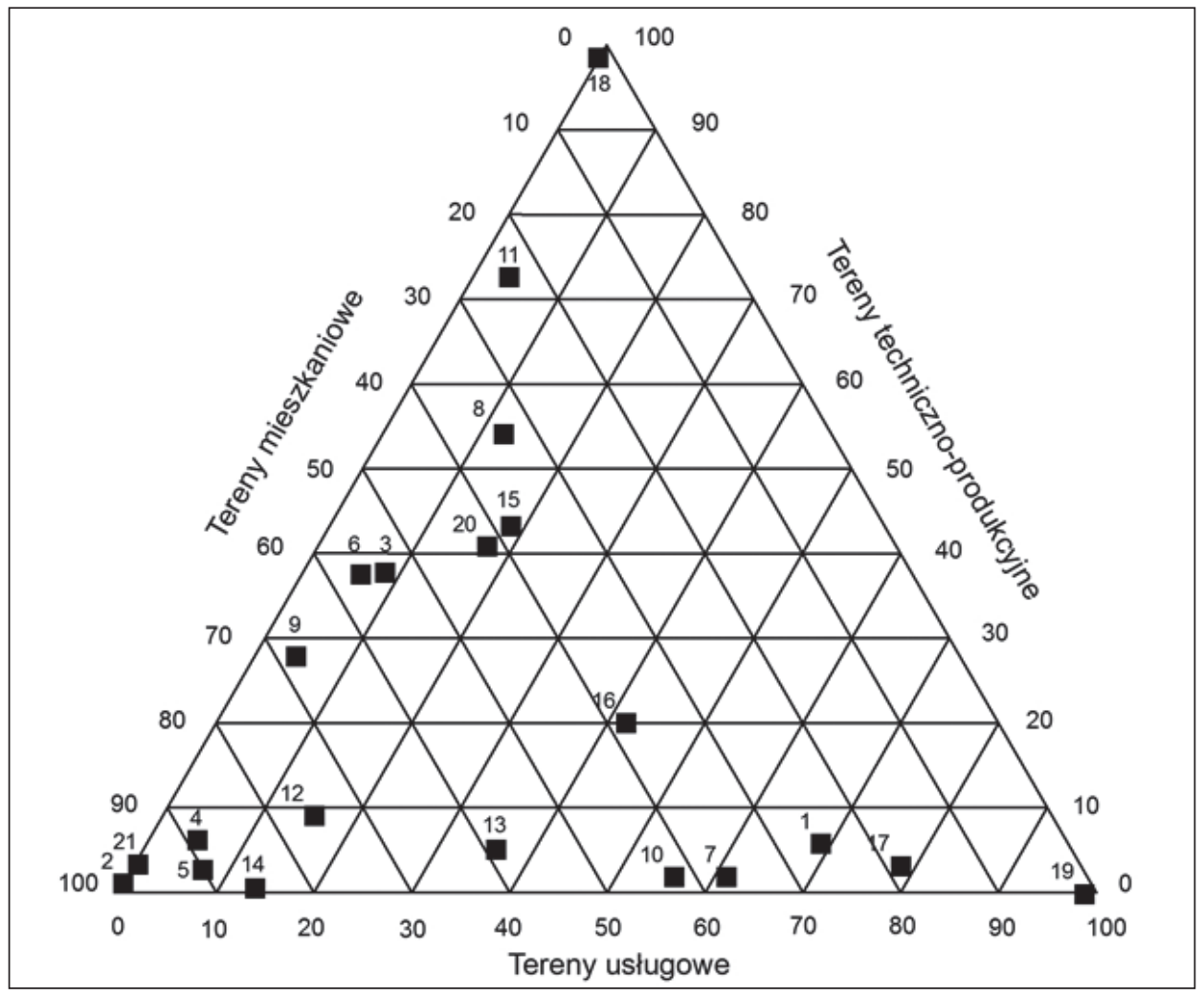

Rycina 3.6. Zróżnicowanie terenów zagrożonych powodziami pod względem struktury użytkowania terenów zabudowanych

1 - Burzenin, 2 - Czarnocin, 3 - Działoszyn, 4 - Gidle, 5 - Sieradz (gmina wiejska), 6 - Tomaszów Mazowiecki (gmina wiejska), 7 - Inowłódz, 8 - Ładzice, 9 - Łowicz, 10 - Sieradz (miasto), 11 -Tomaszów Mazowiecki (miasto), 12 - Pęczniew, 13 - Poddębice, 14 - Radomsko, 15 - Rozprza, 16 - Sulejów, 17 - Uniejów, 18 - Warta, 19 - Zapolice, 20 - Kutno, 21 - Żytno Źródło: opracowanie własne, 2013

W grupie terenów zabudowanych na obszarach zalewowych badanych gmin dominują tereny mieszkaniowe. Ich największy udział jest w gminach: Czarnocin, Żytno oraz Sieradz (gmina wiejska), i wynosi odpowiednio: 99,99\%, $96,85 \%, 90,27 \%$. W Gidlach zabudowa mieszkaniowa zajmuje 58,4 ha w granicach wody $1 \%$. Znajduje się ona głównie w południowej części obszaru badań, w miejscowościach: Borowa, Zabrodzie i Skrzypiec, a także na lewym brzegu rzeki Warty w Rudzie, Górkach i Gowarzowie. Tereny usługowe zajmują powierzchnię 4,27 ha. Należą do nich: 3 sklepy spożywcze (w Gowarzowie oraz Borowej), posterunek straży pożarnej (na prawym brzegu Warty), Kościół pw. NMP Bolesnej, szpital powiatowy (w Radomsku, oddział w Pławnie, leczenie gruźlicy i chorób płuc). Na obszarze zalewowym w gminie Radomsko 


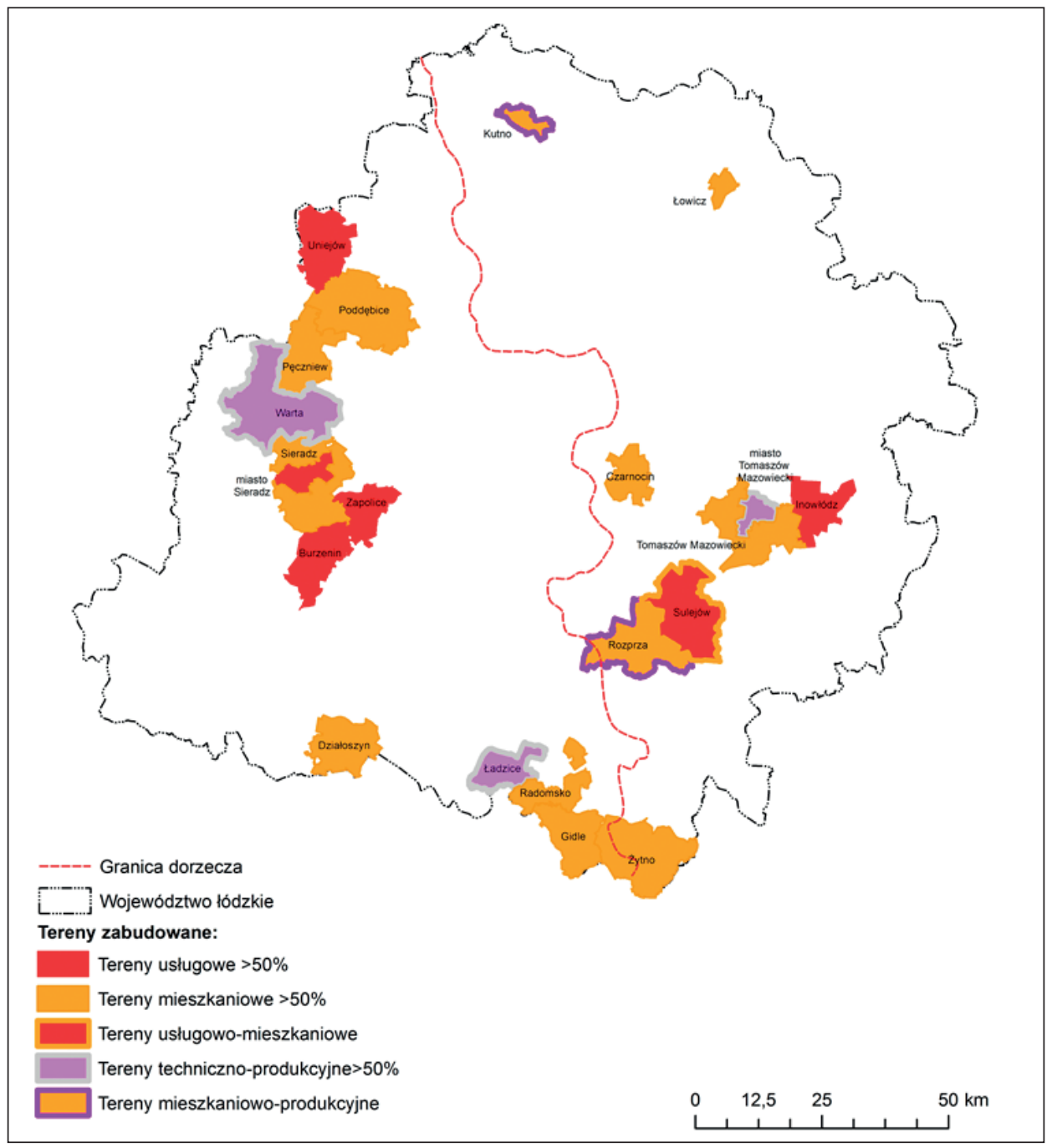

Rycina 3.7. Typy terenów zabudowanych na obszarach zagrożonych powodziami w badanych gminach województwa łódzkiego Źródło: opracowanie własne, 2013

tereny mieszkaniowe jednorodzinne zajmują 22,5 ha. Zabudowa zlokalizowana jest po obu stronach rzeki Warty. Szerokość równiny zalewowej wynosi od $1 \mathrm{~km}$ na zachodzie do ok. 1,5 km we wschodniej części gminy. W gminie Pęczniew tereny mieszkaniowe stanowią 75,38\%, usługowe - 15,07\%, natomiast techniczno-produkcyjne - 9,53\% terenów antropogenicznych, na obszarze szczególnego zagrożenia powodzią. Budynki mieszkalne jednorodzinne zlokalizowane są w północnej części analizowanego obszaru, na wschodnim brzegu rzeki Warty. 
Do obiektów usługowych na badanym obszarze zaliczono Ośrodek Wczasowy „Leśne Domki” w Księżych Młynach, pawilon handlowo-usługowy oraz posterunek straży pożarnej. Ponadto w północnej części zbiornika wodnego, na terenie zalewowym gminy Pęczniew zlokalizowana została Elektrownia Wodna Jeziorsko (obiekt techniczno-produkcyjny), która zajmuje powierzchnię ok. 1 ha. Na obszarze zagrożonym powodzią w Łowiczu tereny zabudowy mieszkaniowej jednorodzinnej zajmują powierzchnię 10,9 ha, natomiast wielorodzinnej 1 ha. W gminie Poddębice zabudowa mieszkaniowa stanowi 59\% terenów zabudowanych w granicach obszarów zalewowych. Budynki mieszkalne jednorodzinne zlokalizowane są głównie na równinie zalewowej Pisi oraz Neru, w Starym i Nowym Pudłowie, Pudłówku, Feliksowie. Tereny usługowe zajmują ok. 20 ha (36,2\% terenów zabudowanych). Na terenie zalewowym gminy Tomaszów Mazowiecki udział zabudowy mieszkaniowej jednorodzinnej w grupie terenów antropogenicznych wynosi $55,2 \%$, techniczno-produkcyjnej - 38,5\%, natomiast usługowej-6,3\%. Budynki mieszkalne znajdują się głównie wzdłuż Piasecznicy. $\mathrm{Na}$ badanym obszarze zlokalizowano firmy zajmujące się m.in. produkcją płytek ceramicznych (nad Czarną), przeróbką drewna (nad Piasecznicą), utylizacją odpadów (nad Piasecznicą), produkcją artykułów spożywczych (nad Wolbórką). Ponadto na lewym brzegu Wolbórki jest Zespół Szkół im. Jana Pawła II w Zawadzie. W Działoszynie zabudowa mieszkaniowa stanowi 54,5\% terenów zabudowanych, techniczno-produkcyjna $-37 \%$, natomiast usługowa $-8,5 \%$. Budynki mieszkalne jednorodzinne zlokalizowane są w centralnej części terenu zagrożonego powodzią, na wschód i zachód od głównego koryta rzeki Warty, w miejscu, gdzie szerokość równiny zalewowej wynosi ponad $1 \mathrm{~km}$. Do zabudowy techniczno-produkcyjnej w granicach wody $1 \% \mathrm{w}$ Działoszynie zaliczono firmy produkcyjne (50\%), zajmujące się m.in. przetwórstwem owocowo-warzywnym oraz oczyszczalnię ścieków. Wśród zabudowy usługowej zinwentaryzowano Szkołę Podstawową nr 1, hotel oraz stację paliw. W Inowłodzu w grupie terenów antropogenicznych na terenie zalewowym dominują tereny usługowe $(61,7 \%$ terenów zabudowanych), a wśród nich ośrodek konferencyjno-wypoczynkowy Chrześcijańskiego Centrum Fundacji „Proem”, sklep spożywczy w budynku zabytkowej synagogi. Zabudowa mieszkalna jednorodzinna (35,5\% terenów antropogenicznych) zajmuje ok. 6 ha i jest zlokalizowana głównie w centralnej części badanego obszaru, po obu stronach Pilicy.

Zabudowa techniczno-produkcyjna (w grupie terenów zabudowanych) dominuje na obszarach zalewowych gmin: Warta, Tomaszów Mazowiecki (miasto), Ładzice, stanowiąc odpowiednio $100 \%, 71,6 \%$ oraz $55,16 \%$ terenów zabudowanych. W Tomaszowie Mazowieckim w granicach zalewu znajdują się firmy produkcyjne, oczyszczalnia ścieków, stacja elektroenergetyczna, przepompownia, które łącznie zajmują powierzchnię ok. 78 ha. W Ładzicach zabudowa stanowi zaledwie $1 \%$ terenów zagrożonych powodziami, z czego ponad połowa powierzchni 
przypada na obiekty techniczno-produkcyjne (51\%). Nad zalewem w Zakrzówku zlokalizowano pompownię wody (w zachodniej części). Zabudowa mieszkaniowa znajduje się na obrzeżach terenu wody $1 \%$ (33,7\% terenów zabudowanych). Na północny wschód od zalewu jest wypożyczalnia kajaków. W mieście i gminie Warta, na zachodnim brzegu zbiornika Jeziorsko zlokalizowano oczyszczalnię ścieków, która jest jedynym budynkiem w granicach wody $1 \%$.

W dwóch gminach: Rozprza oraz Kutno, brak jest jednej dominującej funkcji w grupie terenów zabudowanych na obszarach zalewowych. W Rozprzy największy udział przypada na zabudowę techniczno-produkcyjną - 41,4\% oraz mieszkaniową - 39,7\%. Tereny mieszkalne jednorodzinne znajdują się głównie w miejscowości Łochyńsko oraz Rozprza, w centralnej części powierzchni zalewowej Luciąży. Na analizowanym obszarze zlokalizowany jest również skład węgla oraz tartak (na lewym brzegu Luciąży - w centralnej części obszaru badań). Do zabudowy usługowej w granicach terenu zalewowego należą: dom opieki społecznej w Łochyńsku oraz hotel, zlokalizowany w północno-zachodniej części Zalewu Cieszanowickiego. W Kutnie udział zabudowy techniczno-produkcyjnej oraz mieszkaniowej wynosi odpowiednio $41 \%$ i $42,25 \%$. W granicach wody $1 \%$ znajdują się firmy produkcyjne, zakład gospodarowania odpadami oraz stacja pomp, które zlokalizowane zostały głównie na zachód od centralnej części miasta. Zabudowa mieszkaniowa jednorodzinna zajmuje łącznie powierzchnię ok. 9,5 ha w północno-zachodniej części obszaru badań w Kutnie.

W czterech gminach: Zapolice, Uniejów, Burzenin, Sieradz (miasto) w granicach zalewu, w grupie terenów antropogenicznych dominuje zabudowa usługowa, która stanowi odpowiednio - 99,3\%, 78,6\%, 69,3\% oraz 56,7\%. W Zapolicach zabudowa zajmuje zaledwie 0,36 ha na obszarze zalewowym. Są to domki letniskowe zlokalizowane w południowo-zachodniej części zalewu. Na obszarze szczególnego zagrożenia powodzią w Uniejowie tereny usługowe zajmują powierzchnię ok. 11 ha. Do tej grupy należą: zamek, baseny termalne, Kasztel Rycerski, Zagroda Młynarska, Instytut Zdrowia Człowieka. W Burzeninie zabudowa letniskowa zajmuje 3,7 ha, mieszkaniowa - 1,3 ha, natomiast techniczno-produkcyjna - 0,3 ha na terenie zalewowym. Do terenów usługowych, zlokalizowanych na obszarze zagrożonym powodzią w Sieradzu (mieście), należą: Miejski Ośrodek Sportu i Rekreacji (MOSiR), Wyższa Szkoła Kupiecka, przedszkole, Sieradzki Park Etnograficzny oraz Wzgórze Zamkowe. Znajdują się one na lewym brzegu Warty w miejscu, gdzie szerokość równiny zalewowej wynosi ok. $2 \mathrm{~km}$.

Sulejów wyróżnia się strukturą terenów zabudowanych w grupie badanych gmin. Na obszarze zagrożonym powodzią udział terenów mieszkaniowych oraz usługowych (w grupie terenów zabudowanych) wynosi odpowiednio 38\% i 41,7\%. Budynki mieszkalne jednorodzinne zlokalizowane są głównie wzdłuż Luciąży. Do grupy terenów usługowych zaliczono: port jachtowy „U Bosmana” 
(w miejscowości Barkowice Mokre, na zachodnim brzegu Zalewu Sulejowskiego), ośrodek wczasowo-kolonijny w Białej nad Pilicą oraz Międzynarodowy Ośrodek Integracji Młodzieży Polskiej (zlokalizowany na lewym brzegu Pilicy).

Od dawna doliny rzeczne stanowiły niezwykle atrakcyjne miejsce zarówno dla rozwoju rolnictwa, jak i osadnictwa. Jednak wraz z rozwojem miast i zajmowaniem coraz większych obszarów pod budownictwo oraz infrastrukturę komunikacyjną na obszarze dolin rzecznych, doprowadzono do konieczności podejmowania działań związanych z ochroną przed powodzią tych terenów. W ostatnich latach zauważa się wzrost zainteresowania możliwością przywrócenia rzekom ich rangi i atrakcyjności. Wykorzystuje się je głównie dla celów turystyki i rekreacji. Jednak sposób zagospodarowania terenów nadrzecznych stanowi przedmiot licznych dyskusji (Dusza, Nowak 2007). W badanych gminach dominującym typem użytkowania terenów bezpośredniego (szczególnego) zagrożenia powodzią są tereny wolne od zabudowy, a wśród nich głównie rolne. W związku z tym ryzyko powodziowe, czyli kombinacja prawdopodobieństwa wystąpienia powodzi i związanych z nią potencjalnych negatywnych konsekwencji dla zdrowia ludzkiego, środowiska, dziedzictwa kulturowego oraz działalności gospodarczej jest w tym przypadku znacznie mniejsze niż, gdyby dominowały tereny zabudowane.

\subsection{Próba typologii}

Na kolejnym etapie dokonano klasyfikacji gmin, biorąc pod uwagę wszystkie formy użytkowania terenów zagrożonych powodziami. W tym celu wykorzystano metodę skupień, w której zastosowano miarę odległości euklidesowej i metodę aglomeracji Warda. W wyniku przeprowadzonej analizy wyodrębniono 7 grup gmin o podobnej strukturze zagospodarowania (rycina 3.8).

W pierwszej grupie znalazło się 7 gmin - Czarnocin, Gidle, Sieradz (gmina wiejska), Łowicz, Poddębice, Radomsko, Żytno, w granicach których tereny rolne zajmują ok. $80 \%$ terenów zalewowych, lasy $12 \%$, tereny wód $5 \%$. Tereny zabudowane stanowią zaledwie ok. 1,4\% terenów zagrożonych, z czego największy udział ma zabudowa mieszkaniowa - ok. 1,2\%, w szczególności w gminach: Gidle oraz Radomsko. Do drugiej grupy zaklasyfikowano 4 gminy: Burzenin, Działoszyn, Ładzice i Zapolice. W granicach terenów wody 100-letniej znaczną powierzchnię zajmują w nich zarówno tereny rolne $-50 \%$, lasy $37 \%$ oraz wody $10 \%$. Wskaźnik poziomej intensywności zagospodarowania w tej grupie wynosi $1 \%$, z czego połowa $(0,51 \%)$ zabudowy pełni funkcję mieszkaniową. Trzecia grupa reprezentowana jest przez dwie gminy - Pęczniew oraz Wartę. Charakteryzują się one dominacją terenów wód w granicach wody $1 \%$, które stanowią ok. $74 \%$ zalewu, co jest związane $\mathrm{z}$ istnieniem zbiornika Jeziorsko. Tereny rolne zajmują 14\% 


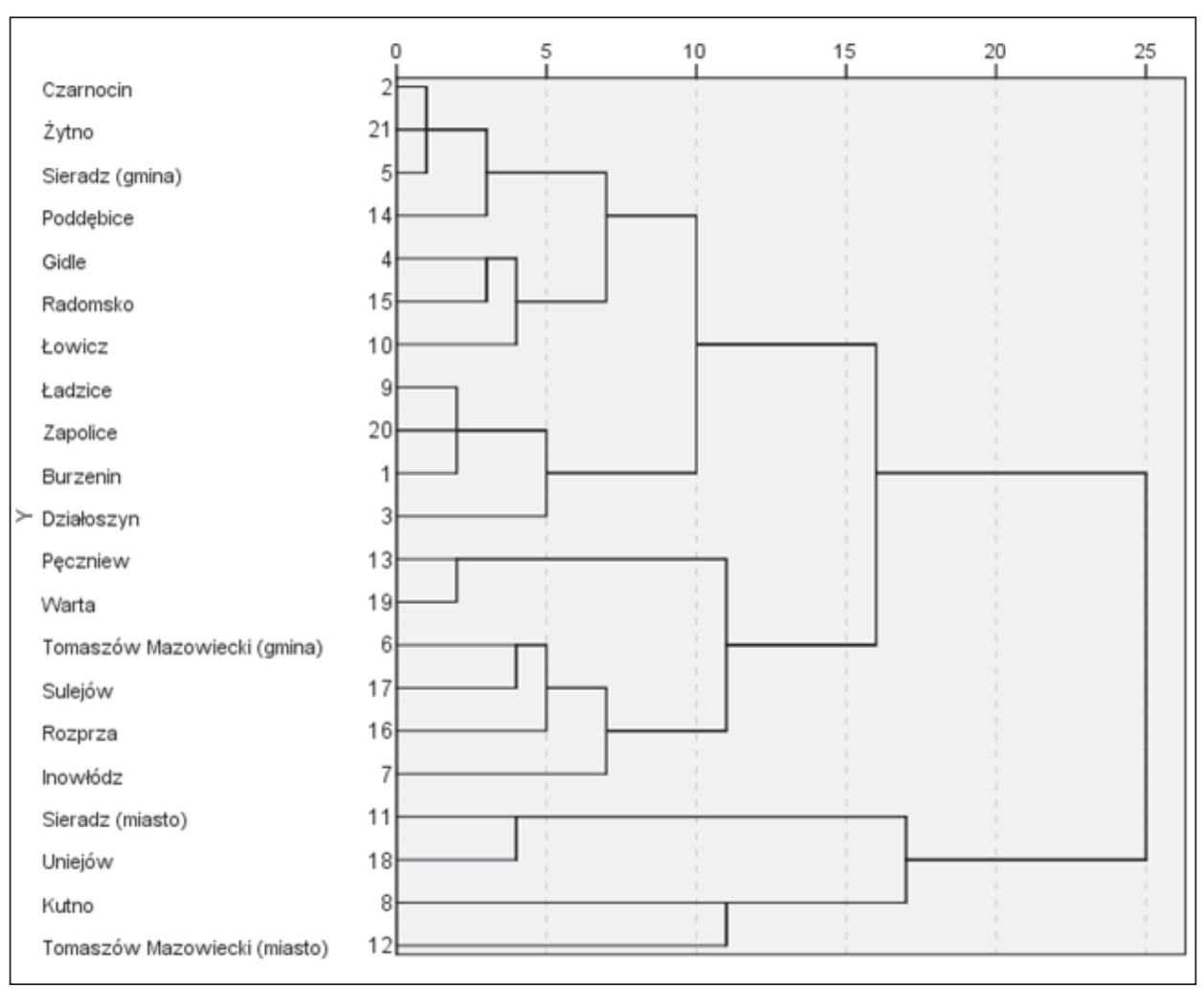

Rycina 3.8. Gminy o podobnej strukturze zagospodarowania terenów zagrożonych powodziami w województwie łódzkim

Źródło: opracowanie własne, 2014

badanego obszaru, lasy $11 \%$, natomiast tereny zabudowane tylko $0,17 \%$. W kolejnej grupie znajdują się następujące gminy: Tomaszów Mazowiecki (gmina wiejska), Inowłódz, Rozprza oraz Sulejów. Największy udział w granicach terenów zalewowych przypada na tereny rolne - 50\%. Tereny wód stanowią 25\% (z czego największa ich powierzchnia jest $w$ granicach Tomaszowa Mazowieckiego, co jest związane z istnieniem zbiornika Sulejów), a lasy $22 \%$ powierzchni zalewu. Podobieństwo pod wzglądem struktury zagospodarowania terenów w granicach wody 100-letniej wykazują również Uniejów oraz Sieradz (miasto). Tereny rolne zajmują tam aż $72 \%$ zalewu, lasy ok. $11 \%$, tereny wód 8,6\%. Tereny zabudowane stanowią $1,2 \%$ zalewu, z czego największą powierzchnię zajmują tereny mieszkaniowe $(0,67 \%)$ oraz usług $(0,54 \%)$. Pozostałe grupy reprezentowane są przez pojedyncze gminy - Kutno oraz Tomaszów Mazowiecki (miasto) (tabela 3.3).

Duża liczba wyodrębnionych grup świadczy o zróżnicowaniu terenów zagrożonych powodziami pod względem struktury zagospodarowania. 
Tabela 3.3. Struktura zagospodarowania terenów zagrożonych powodziami w wyodrębnionych grupach gmin województwa łódzkiego

\begin{tabular}{|c|c|c|c|c|c|c|c|c|c|c|c|c|}
\hline \multirow[b]{2}{*}{$\begin{array}{l}\text { Grupy } \\
\text { gmin }\end{array}$} & \multicolumn{12}{|c|}{$\begin{array}{l}\text { Udział poszczególnych form użytkowania ziemi w granicach wody } 100 \text {-letniej } \\
\text { w wyodrębnionych grupach gmin województwa łódzkiego (\% - średnia arytmetyczna) }\end{array}$} \\
\hline & 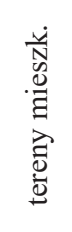 & 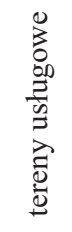 & 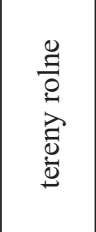 & 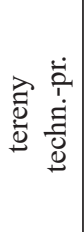 & 氞 & 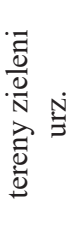 & 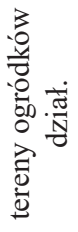 & $\begin{array}{l}\vec{D} \\
\vdots \\
\overrightarrow{0} \\
\overrightarrow{0} \\
\vec{\Xi}\end{array}$ & 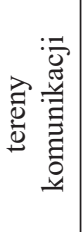 & 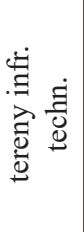 & 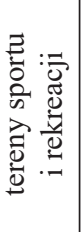 & 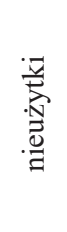 \\
\hline 1. & 1,18 & 0,05 & 79,80 & 0,08 & 12,97 & 0,00 & 0,08 & 5,37 & 0,22 & 0,12 & 0,13 & 0,01 \\
\hline 2. & 0,52 & 0,06 & 50,49 & 0,26 & 37,72 & 0,07 & 0,00 & 10,42 & 0,12 & 0,15 & 0,18 & 0,01 \\
\hline 3. & 0,18 & 0,04 & 14,14 & 0,00 & 11,18 & 0,00 & 0,00 & 74,36 & 0,07 & 0,03 & 0,00 & 0,00 \\
\hline 4. & 0,54 & 0,21 & 50,16 & 0,21 & 22,34 & 0,00 & 0,00 & 25,91 & 0,12 & 0,09 & 0,25 & 0,17 \\
\hline 5. & 0,67 & 0,54 & 72,76 & 0,04 & 11,65 & 3,80 & 0,57 & 8,62 & 0,39 & 0,01 & 0,90 & 0,03 \\
\hline 6. & 3,24 & 0,06 & 85,67 & 3,04 & 1,04 & 0,00 & 3,00 & 1,05 & 1,52 & 0,11 & 1,22 & 0,04 \\
\hline 7. & 3,57 & 0,49 & 57,57 & 4,70 & 20,28 & 0,02 & 1,71 & 4,94 & 0,95 & 5,59 & 0,01 & 0,16 \\
\hline
\end{tabular}

Źródło:opracowanie własne, 2014.

\subsection{Użytkowanie ziemi w wybranych gminach}

Szczegółową analizę zagospodarowania przeprowadzono na przykładzie trzech gmin miejskich: Tomaszów Mazowiecki, Kutno oraz Łowicz, w których obszary szczególnego zagrożenia powodzią mają najwyższy wskaźnik poziomej intensywności użytkowania. W przypadku miasta Tomaszów Mazowiecki ok. 14\% terenów zagrożonych powodziami zajętych jest pod zabudowę, głównie techniczno-produkcyjną, w mieście Kutno ok. 7,5\%, w Łowicz ok. 4,5\%. Wzrost obszarów zabudowanych na terenach zagrożonych powodziami doprowadza na ogół do zwiększenia rozmiarów i częstotliwości powodzi (Konrad 2003).

Miasto Tomaszów Mazowiecki powstało nad rzeką Pilicą, w sąsiedztwie węzła hydrologicznego, jaki tworzą uchodzące do niej Wolbórka (fotografia 3.1), Czarna Bielina, Piasecznica i Lubochenka.

W granicach miasta znajduje się odcinek dolny Pilicy, a także dolne odcinki dolin jej dopływów. Na tym terenie zaznacza się konflikt rodzaju i sposobu zagospodarowania terenów, z uwarunkowaniami przyrodniczymi, przyjętymi jako ograniczenia wykluczające inwestycje mieszkaniowe, usługowe oraz z zakresu produkcji przemysłowej, szczególnie wzdłuż doliny Wolbórki (w centrum miasta) oraz Czarnej i Piasecznicy (w północnej części miasta). Szerokość dna doliny Pilicy w Tomaszowie Mazowieckim jest bardzo zróżnicowana, w południowej 


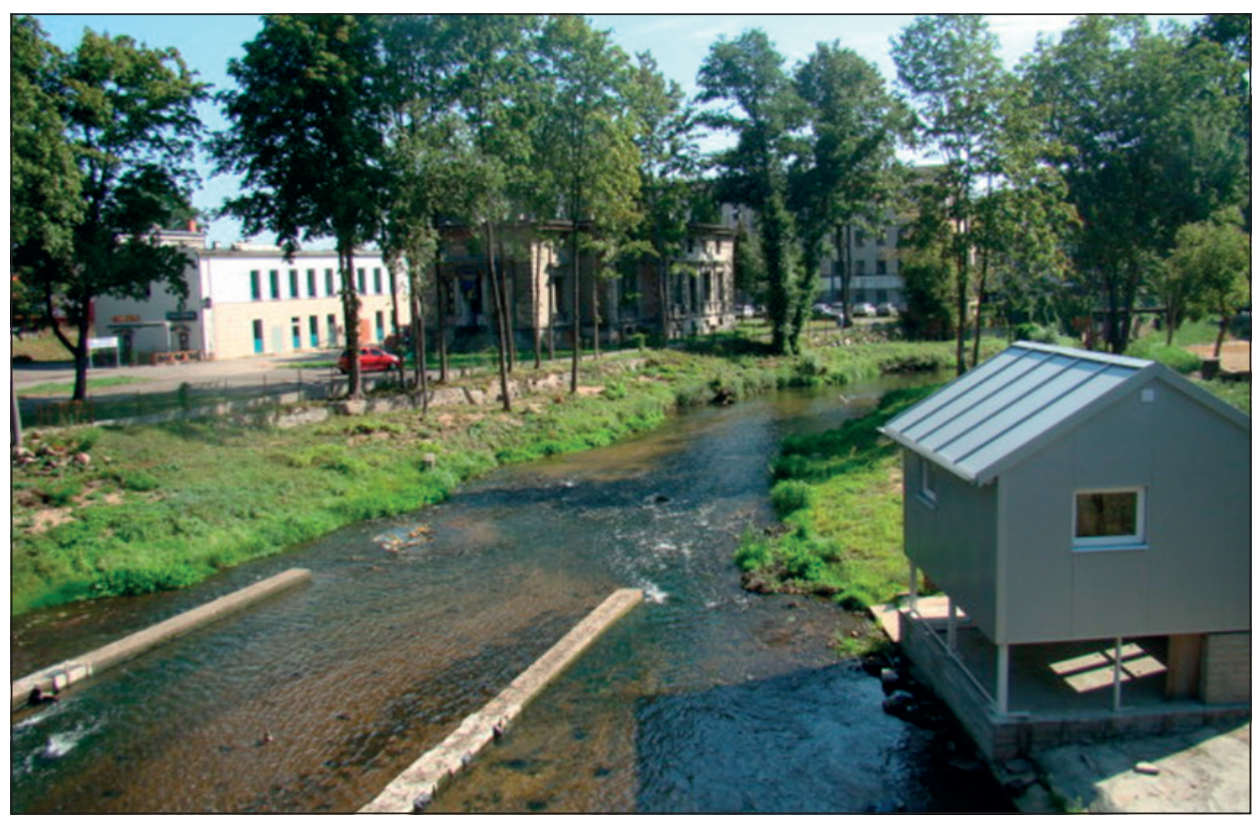

Fotografia 3.1. Rzeka Wolbórka w Tomaszowie Mazowieckim Źródło: M. Borowska-Stefańska, 2012

i środkowej części wynosi od 0,3 km do $1 \mathrm{~km}$, natomiast w północnej, w miejscu ujścia Wolbórki, dochodzi nawet do 1,7 km (Trzmiel 1986). Rzeźba terenu obszarów zalewowych jest mocno zróżnicowana pod względem hipsometrycznym, teren obniża się w kierunku północno-wschodnim. Wysokości wynoszą od ok. 163 m n.p.m. w części zachodniej i południowej, do 153 m n.p.m. w miejscu, gdzie Wolbórka uchodzi do Pilicy.

Tereny zalewowe w mieście zajmują ok.762 ha, z czego największy udział mają tereny rolne $-58 \%$. W grupie tej dominują łąki i pastwiska (427 ha). Grunty orne zajmują 11,5 ha, tereny upraw trwałych, w tym głównie ogródki działkowe, zlokalizowane w zachodniej i północno-zachodniej części miasta, nad rzeką Czarną oraz Wolbórką - 13 ha. Lasy znajdują się wzdłuż Pilicy i pokrywają 20\% powierzchni zalewu. (rycina 3.9).

Łącznie tereny wolne od zabudowy stanowią 84,7\% powierzchni zalewu (rycina 3.10).

W grupie terenów antropogenicznych dominują obiekty infrastruktury technicznej, które zajmują ok. $6 \%$ powierzchni zalewu. Należą do nich: stacja elektroenergetyczna, oczyszczalnia ścieków, przepompownia. Stacja elektroenergetyczna została zlokalizowana nad Czarną i Piasecznicą ( 0,7 ha), oczyszczalnia ścieków (41,5 ha) w miejscu, gdzie szerokość równiny zalewowej wynosi ok. 1 km, przepompownia nad Pilicą $(0,4 \mathrm{ha})$. 


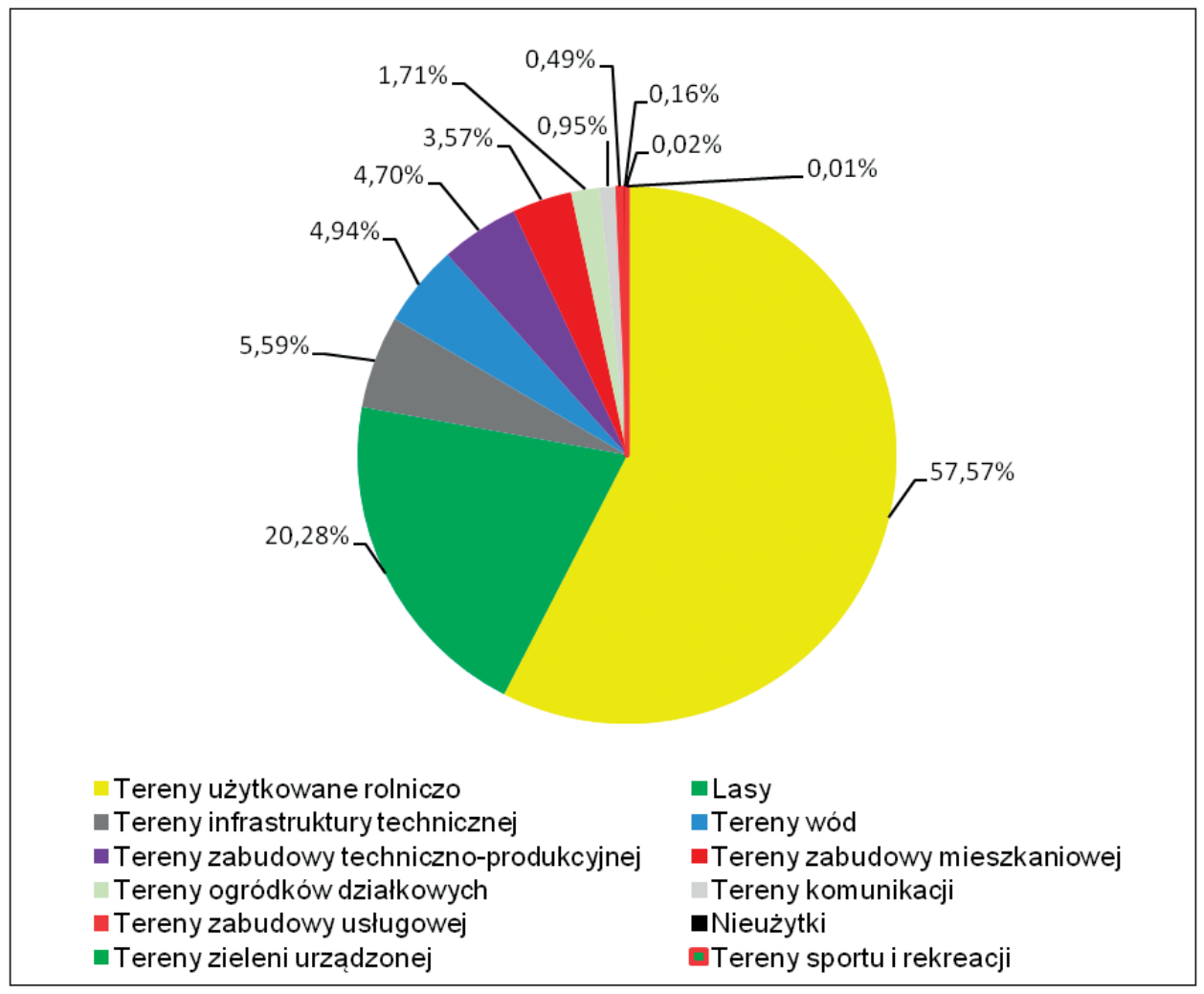

Rycina 3.9. Bilans użytkowania ziemi terenu wody $1 \%$ w Tomaszowie Mazowieckim Źródło: opracowanie własne na podstawie BDOT i inwentaryzacji urbanistycznej, 2012

Wśród terenów mieszkaniowych (3,57\%) zinwentaryzowano zabudowę jednorodzinną, która zlokalizowana jest przede wszystkim wzdłuż Czarnej i Piasecznicy ( 82 budynki) oraz Wolbórki (59 budynków). Budynki mieszkalne znajdują się w zachodniej części miasta, na prawym brzegu Wolbórki, na północ od ul. Hallera oraz przy ul. Nadrzecznej. Do terenów techniczno-produkcyjnych $(4,7 \%)$ zaliczono firmy produkcyjne oraz powiązane $\mathrm{z}$ ich istnieniem składy i magazyny, które lokalizują się głównie w północno-zachodniej części miasta nad rzekami Czarna oraz Piasecznica. Zajmują się one produkcją chrupek (Frito Lay, Ice Full), płytek ceramicznych (Paradyż Sp. z o.o.), obuwia (Comfort Shoes), akcesoriów samochodowych (Polytec Interior). Tereny usługowe, choć stanowią niewielki udział, to jednak z punktu widzenia ochrony przed powodzią stwarzają potencjalne negatywne konsekwencje dla ludzi. Należą do nich m.in. 3 szkoły (Zespół Szkół Ponadgimnazjalnych nr 5, Zespół Placówek Wychowania Pozaszkolnego oraz Zespół Szkół w Komorowie, który częściowo znajduje się również w granicach miasta) oraz liczne punkty usługowe (m.in. sklep meblowy HALIDOR, JYSK). 


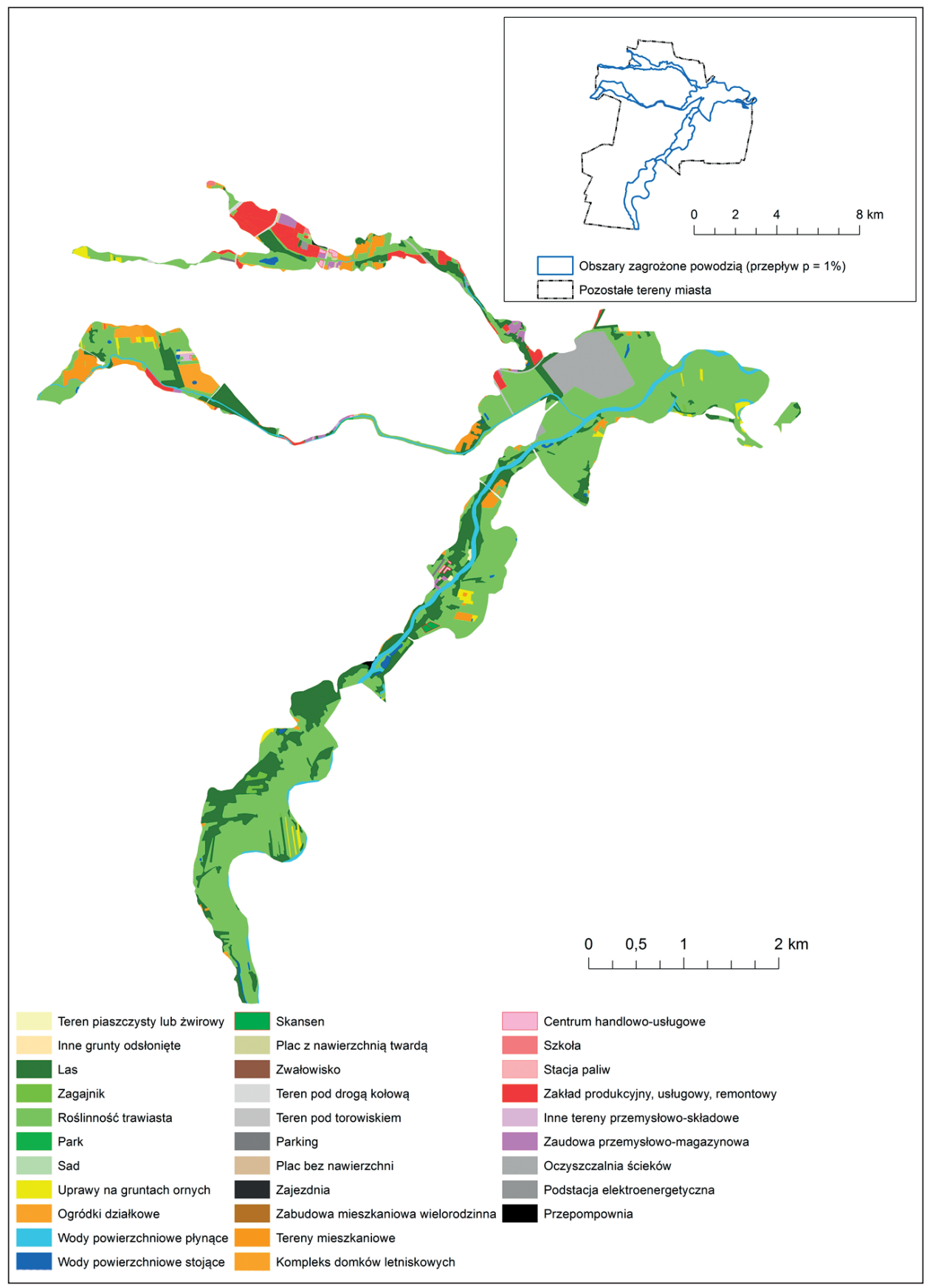

Rycina 3.10. Zagospodarowanie terenu szczególnego zagrożenia powodzią w Tomaszowie Mazowieckim

Źródło: opracowanie własne na podstawie BDOT i inwentaryzacji urbanistycznej, 2012 


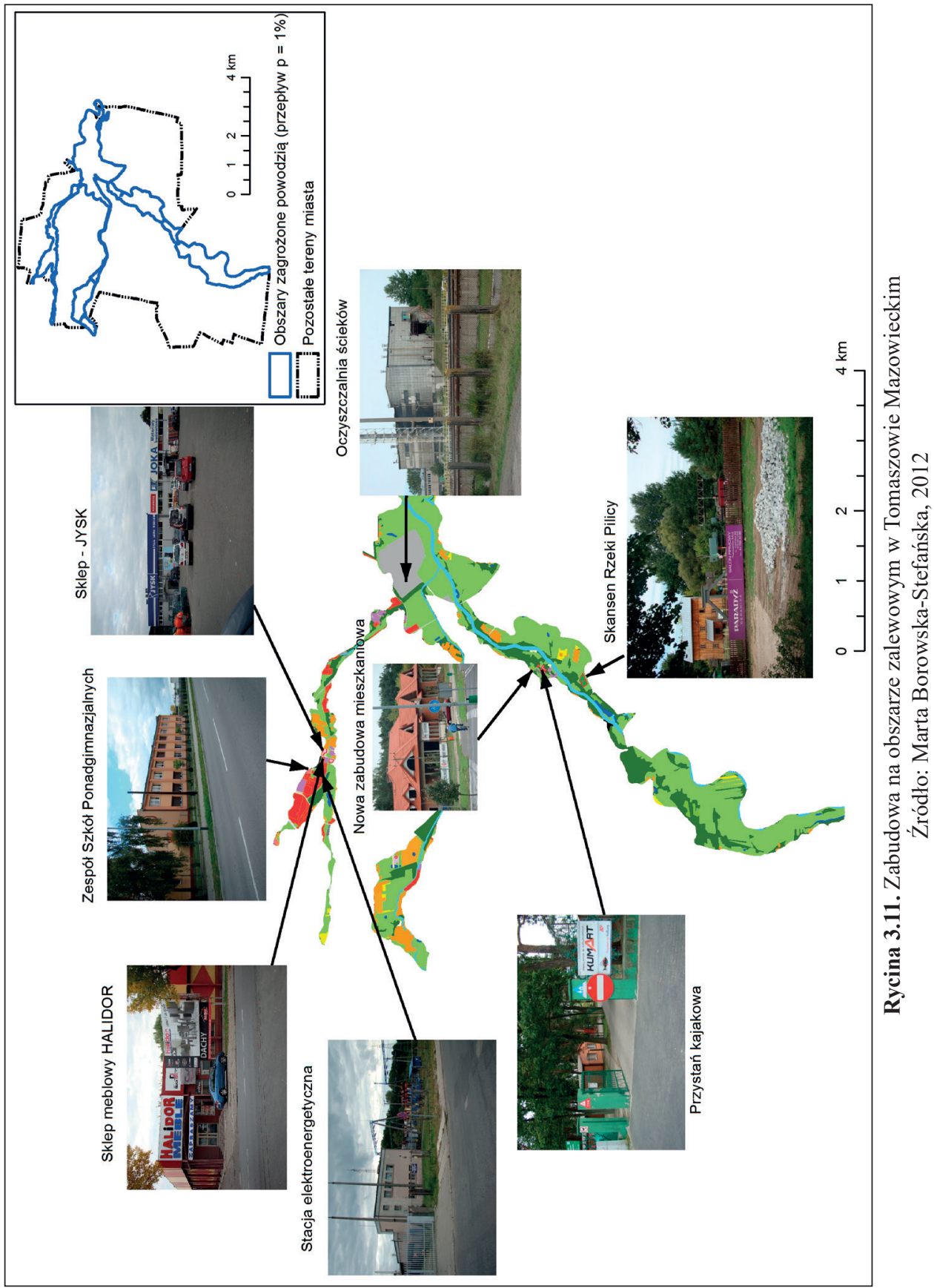


Miasto dysponuje stosunkowo niewielką bazą materialną kultury, jednak na terenie szczególnego zagrożenia powodzią od 2000 r. istnieje Skansen Rzeki Pilicy, gdzie organizowane są kursy językowe, wystawy obrazów, koncerty czy wieczory literackie. Wzdłuż rzeki Wolbórki znajduje się park miejski, przekształcony z dawnego parku dworskiego (Studium... 2009). W granicach omawianego obszaru zlokalizowane są również tereny ogródków działkowych, sportu i rekreacji oraz komunikacji (rycina 3.11).

W Tomaszowie Mazowieckim zabudowa skoncentrowana jest w szczególności wzdłuż mniejszych rzek: Czarnej oraz Piasecznicy, na odcinkach nieobwałowanych oraz w miejscu, gdzie mniejsze rzeki, przepływające przez miasto, uchodzą do Pilicy. Na tym odcinku równina zalewowa jest bardzo szeroka, co sprzyja procesowi intensyfikacji zagospodarowania.

Miasto Kutno powstało nad rzeką Ochnią, która przecina je z północnego zachodu na południowy wschód. Tereny położone wzdłuż tej rzeki są narażone na niebezpieczeństwo powodzi i występuje tu okresowe podtapianie (fotografia 3.2). Zabytkowe centrum chronione jest przez wały przeciwpowodziowe, które znajdują się po obu stronach rzeki (Studium... 2012). W miejscach niechronionych wałami szerokość równiny zalewowej wynosi 300-500 m. Teren zalewowy obniża się w kierunku południowo-wschodnim, gdzie wysokości osiągają ok. $100 \mathrm{~m}$ n.p.m.

Obszar szczególnego zagrożenia powodzią w mieście Kutno ma powierzchnię ok. 292,5 ha, z czego największy udział przypada na tereny rolne - 85,67\%.

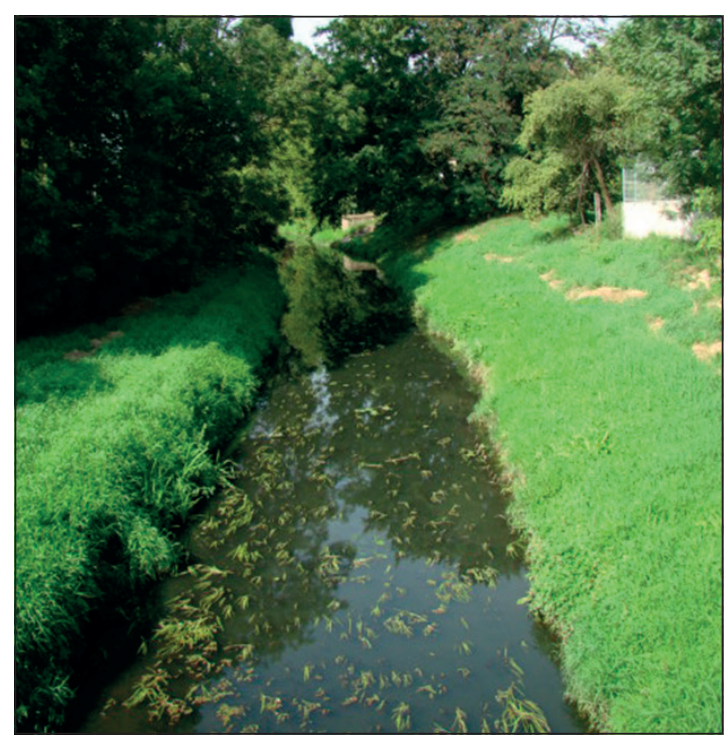

Fotografia 3.2. Rzeka Ochnia w Kutnie Źródło: Marta Borowska-Stefańska, 2012 


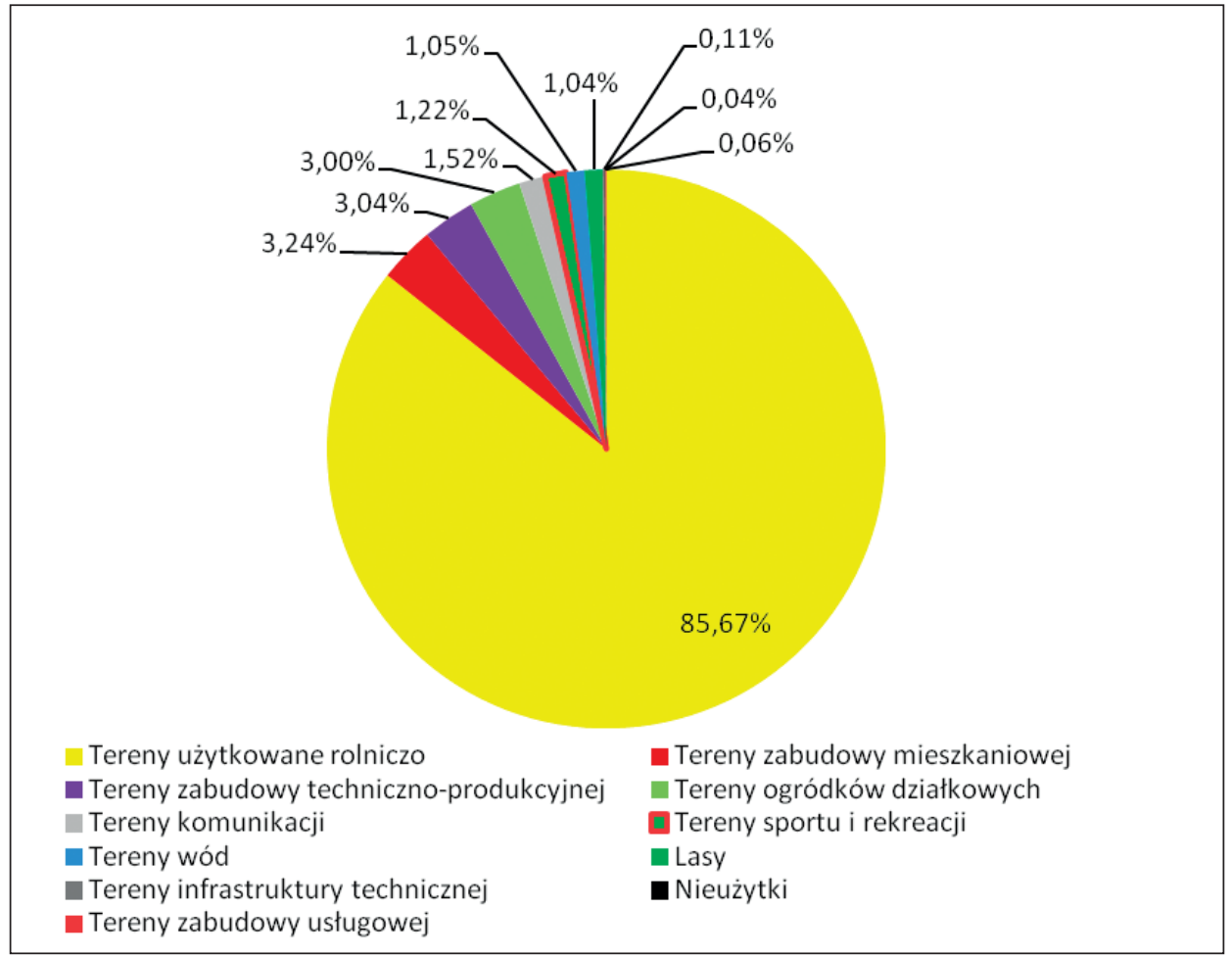

Rycina 3.12. Bilans użytkowania ziemi terenu wody 100 -letniej w Kutnie Źródło: opracowanie własne na podstawie BDOT i inwentaryzacji urbanistycznej, 2012

Grunty orne zajmują ok. 87,7 ha, łąki i pastwiska 163 ha, natomiast ogródki działkowe 8,7 ha (zlokalizowane w północno-zachodniej części badanego obszaru). Tereny wolne od zabudowy stanowią łącznie ok. 90,8\% terenów zalewowych (rycina 3.12).

Tereny zabudowane zajmują ok. 7,5\% powierzchni zalewu, a tereny komunikacji 1,5\% (rycina 3.13). Wśród terenów zabudowanych znaczący udział mają zarówno tereny mieszkaniowe $-3,24 \%$, jak i techniczno-produkcyjne - 3,04\%.

Zabudowa mieszkaniowa to łącznie ponad 100 budynków, zlokalizowanych głównie na lewym brzegu rzeki Ochni. Na omawianym obszarze swoją siedzibę mają firmy zajmujące się branżą budowlaną, systemami alarmowymi, odzyskiwaniem i unieszkodliwianiem odpadów przemysłowych, recyklingiem oraz Mazowiecka Spółka Gazownicza (rycina 3.14). Do terenów usługowych znajdujących się na obszarze zagrożonym powodzią w Kutnie zaliczono m.in. dyskont „Biedronka”, do terenów infrastruktury technicznej - stację pomp. Należy jednak zaznaczyć, że ok. 90\% tych obszarów to tereny wolne od zabudowy, głównie rolne. 


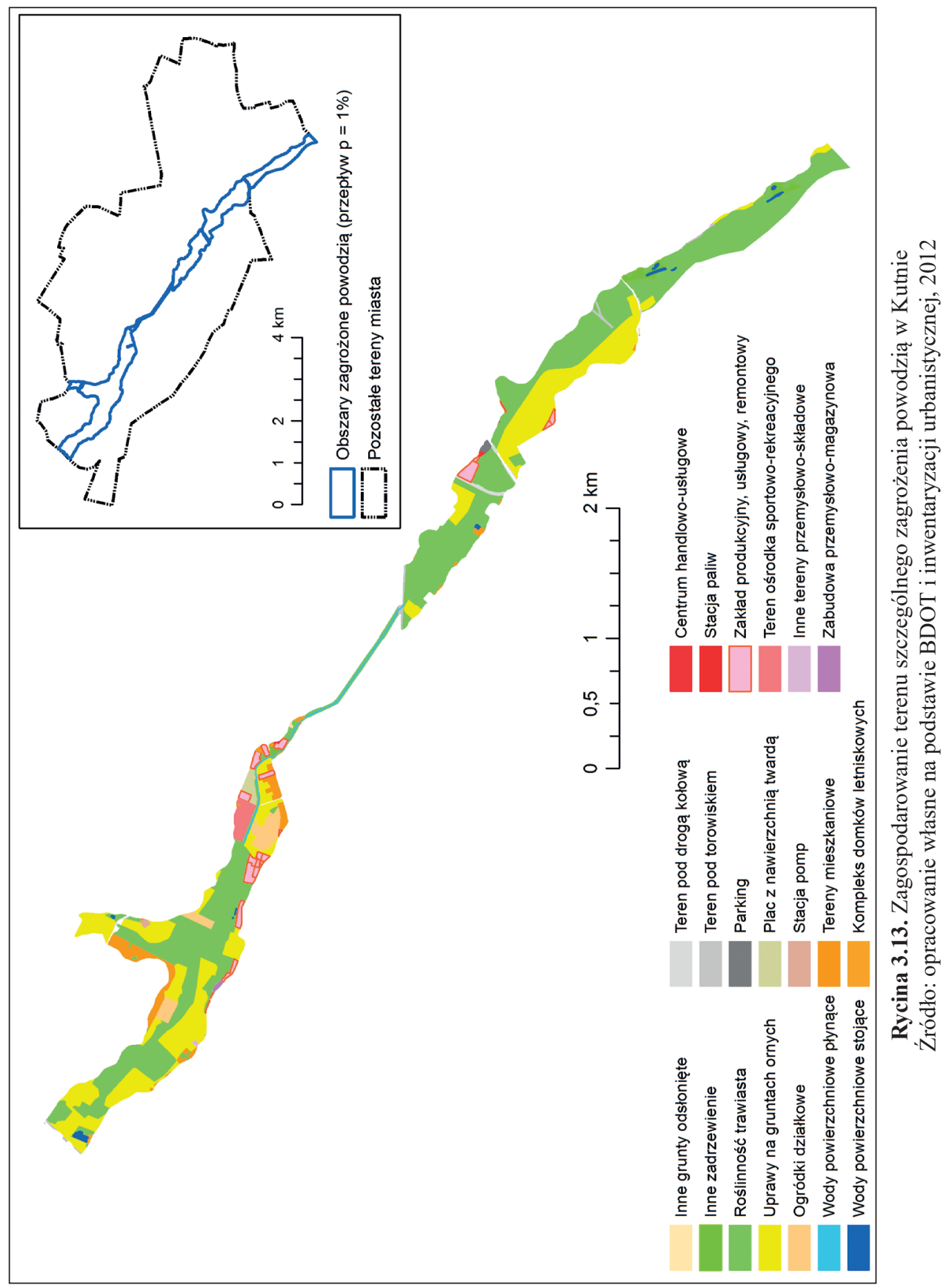




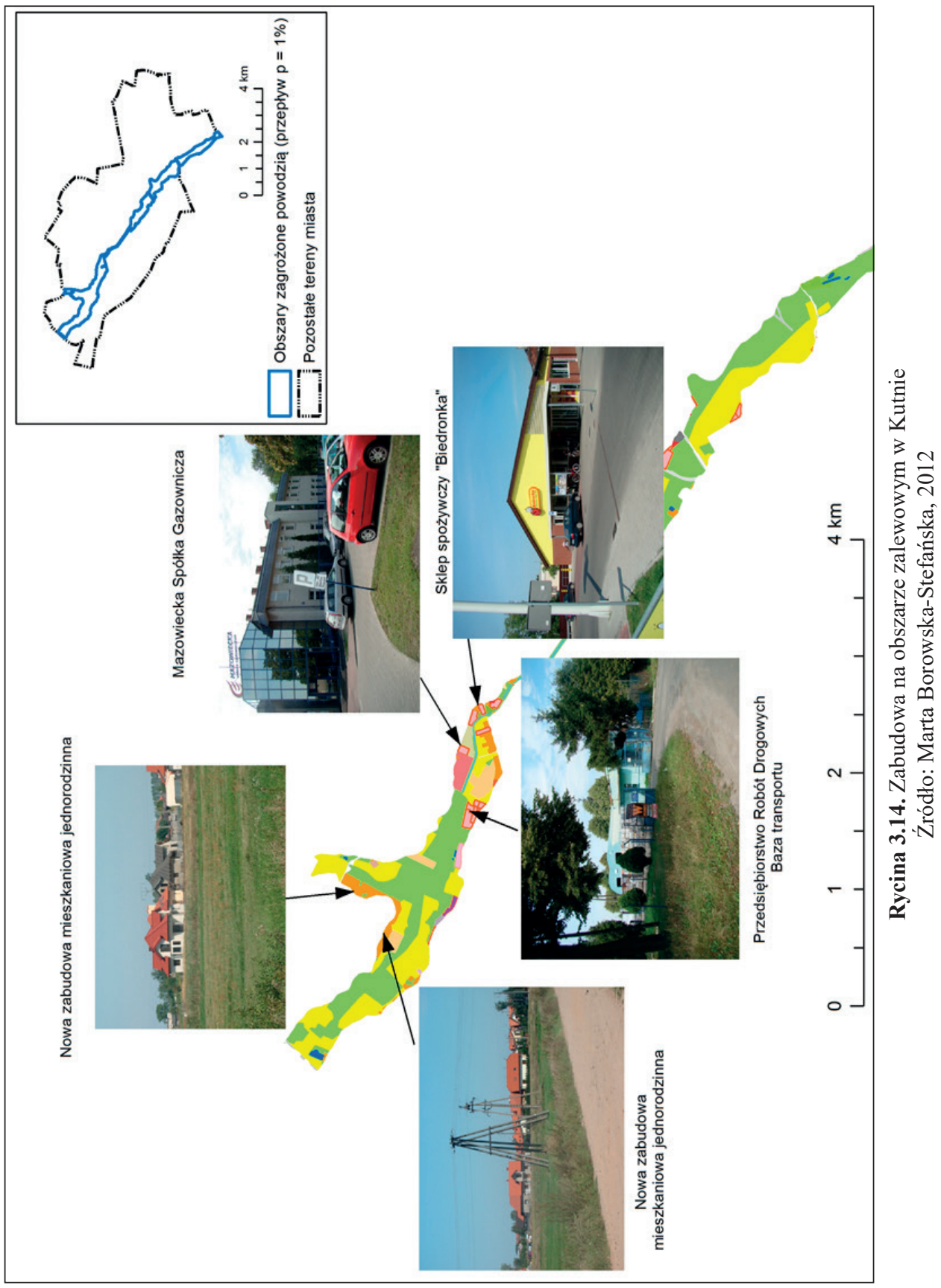




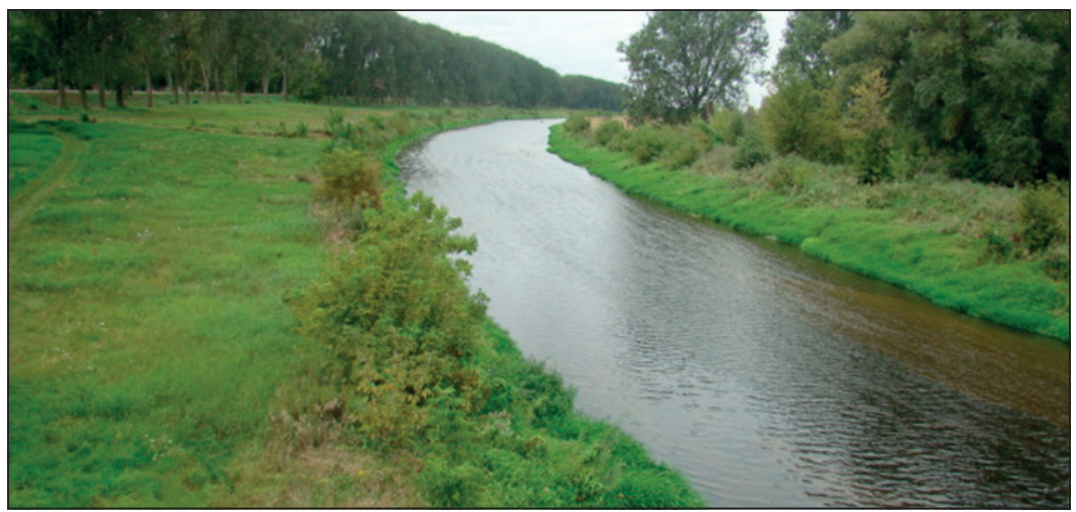

Fotografia 3.3. Rzeka Bzura w Łowiczu

Źródło: M. Borowska-Stefańska, 2012

Miasto Łowicz położone jest w zwężeniu Pradoliny Warszawsko-Berlińskiej, nad rzeką Bzurą (fotografia 3.3). W jego granicach administracyjnych sieć hydrograficzną tworzą: Bzura, Zwierzyniec, Zielkówka, Uchanka, Bobrówka, sieć kanałów i rowów melioracyjnych. Rzeka Bzura stwarza największe zagrożenie powodziowe (Studium... 2003). Współczesny układ sieci rzecznej miasta jest całkowicie sztuczny (Kobojek 2009). Bzura została uregulowana na odcinku od Łowicz do Łęczycy w XIX w., a obecny przebieg koryta w omawianym mieście ukształtowano w latach 1925-1942. Prace regulacyjne oraz melioracyjne doprowadziły do obniżenia poziomu wód gruntowych. Następnie suche lata 80. XX w. wykształciły pogląd o bezpieczeństwie obszarów równiny zalewowej, co w efekcie doprowadziło do zajęcia ich pod zabudowę (Kobojek 2013).

Powierzchnia terenu szczególnego zagrożenia powodzią wynosi 396,24 ha, co stanowi 16,91\% terenu miasta. Na zachód od Łowicza szerokość równiny zalewowej sięga ok. 0,7 km. Dno doliny w centralnej części zwęża się do 0,3-0,4 km. Zostało ono dodatkowe obwałowane i w strefie międzywala jego szerokość wynosi zaledwie 0,15 km (Brzeziński 1990a). Powierzchnia terenu zalewowego obniża się w kierunku wschodnim, gdzie wysokości wynoszą 82,5 m n.p.m. Różnica wysokości względnych to zaledwie $2,5 \mathrm{~m}$. W granicach obszaru zagrożonego powodzią w Łowiczu dominują tereny rolne, które zajmują 347,9 ha, z czego 61\% to użytki zielone, a 39\% - grunty orne (rycina 3.15).

Tereny zabudowane w porównaniu do pozostałych analizowanych gmin zajmują również znaczną powierzchnię ok. 4,5\% (rycina 3.16).

$\mathrm{W}$ grupie terenów zagospodarowanych dominują tereny mieszkaniowe, jedno- (ok. 150) oraz wielorodzinne (3 bloki). Zabudowa jednorodzinna (11 ha) zlokalizowana jest głównie w południowo-zachodniej części analizowanego obszaru, w rejonie ulic: E. Orzeszkowej, Wiatrakowej, Wiosennej, S. Żeromskiego, J. Tuwima, Łąkowej. Osiedle bloków znajduje się przy ul. Marii Konopnickiej i zajmuje powierzchnię 1 ha. Do terenów infrastruktury technicznej na obszarze zagrożonym 


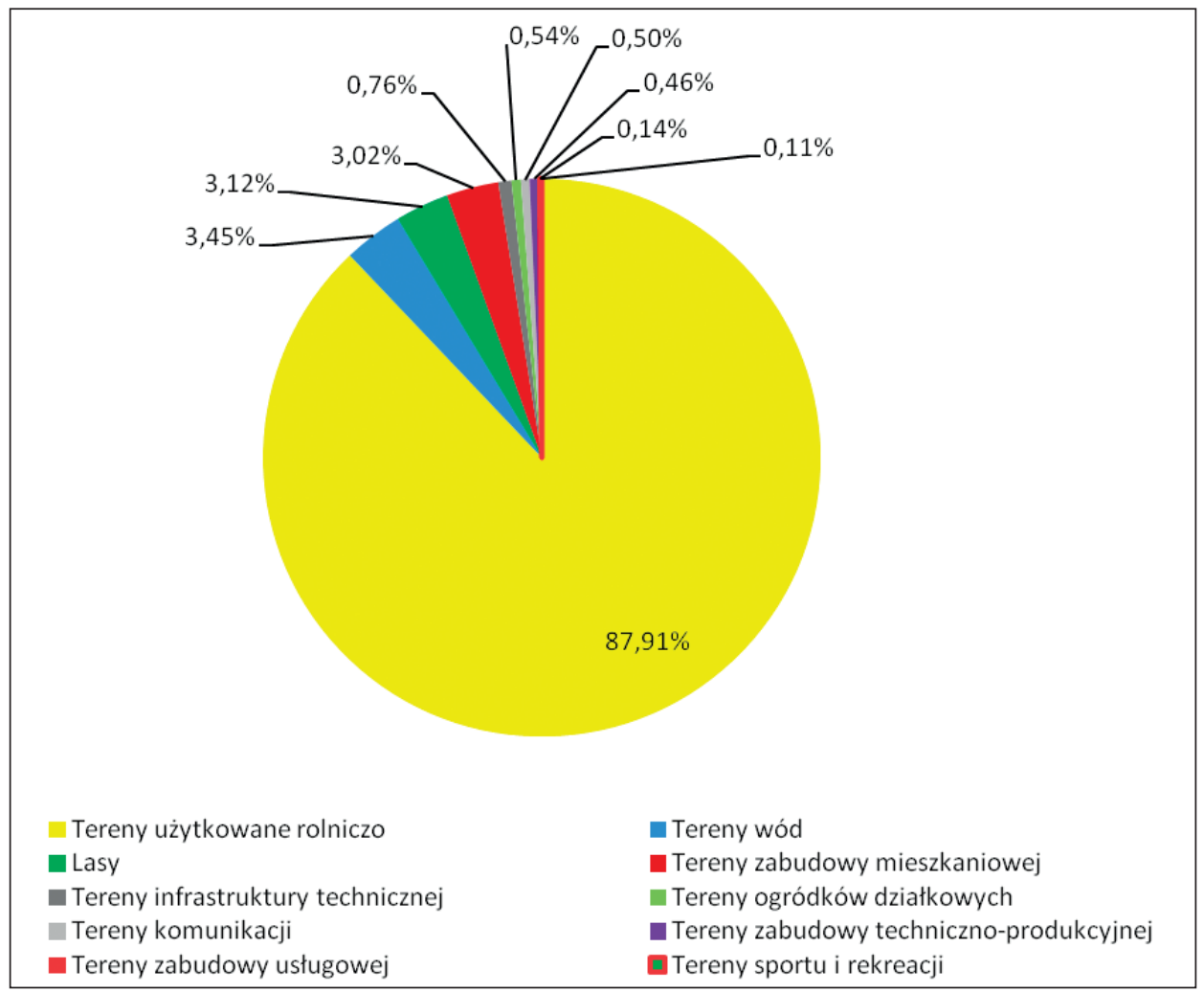

Rycina 3.15. Bilans użytkowania ziemi terenu wody 100-letniej w Łowiczu

Źródło: opracowanie własne na podstawie BDOT i inwentaryzacji urbanistycznej, 2012

powodzią wzdłuż rzeki Bzury zaliczono oczyszczalnię ścieków (1\% powierzchni omawianego obszaru). Na terenie zalewowym w Łowiczu występują liczne punkty usługowe, w tym sklepy spożywcze, punkt weterynaryjny, stacja paliw (rycina 3.17).

Zabudowa terenów szczególnego zagrożenia powodziami powoduje uszczelnianie powierzchni terenu, wskutek czego naturalna retencja powierzchniowa jest coraz mniejsza. Potęguje to również redukcja terenów leśnych. W wyniku tego woda z opadów szybko spływa do rzek, powodując szybsze i większe kulminacje powodzi niż dawniej. Proces ten jest znaczenie bardziej groźny w skutkach na obszarach miejskich. Dlatego tak ważne jest pozostawienie terenów wolnych od zabudowy wszędzie tam, gdzie jest to możliwe, zarówno w miastach, jak i indywidualnych obejściach (Konieczny, Siudak 2010).

Obszary zagrożone powodzią w badanych gminach, w szczególności w granicach Tomaszowa Mazowieckiego, wskazują na ich niewłaściwe zagospodarowanie, co udowadnia, że zarówno władze, jak i mieszkańcy nie doceniają możliwości żywiołu, jakim jest powódź. Zabudowę na tych obszarach powinno się ograniczać do już istniejącej, aby nie zwiększać ryzyka powodziowego. 


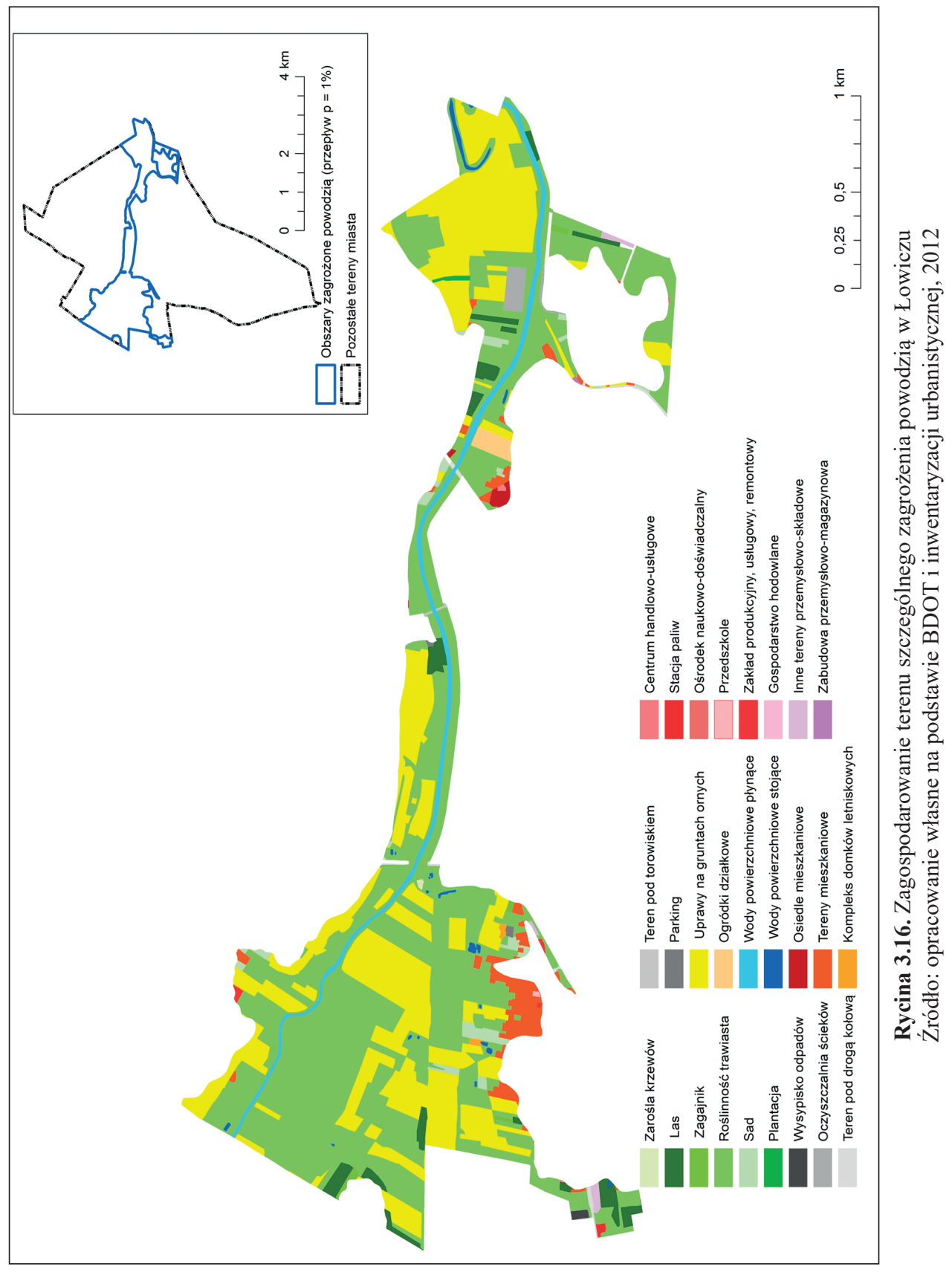




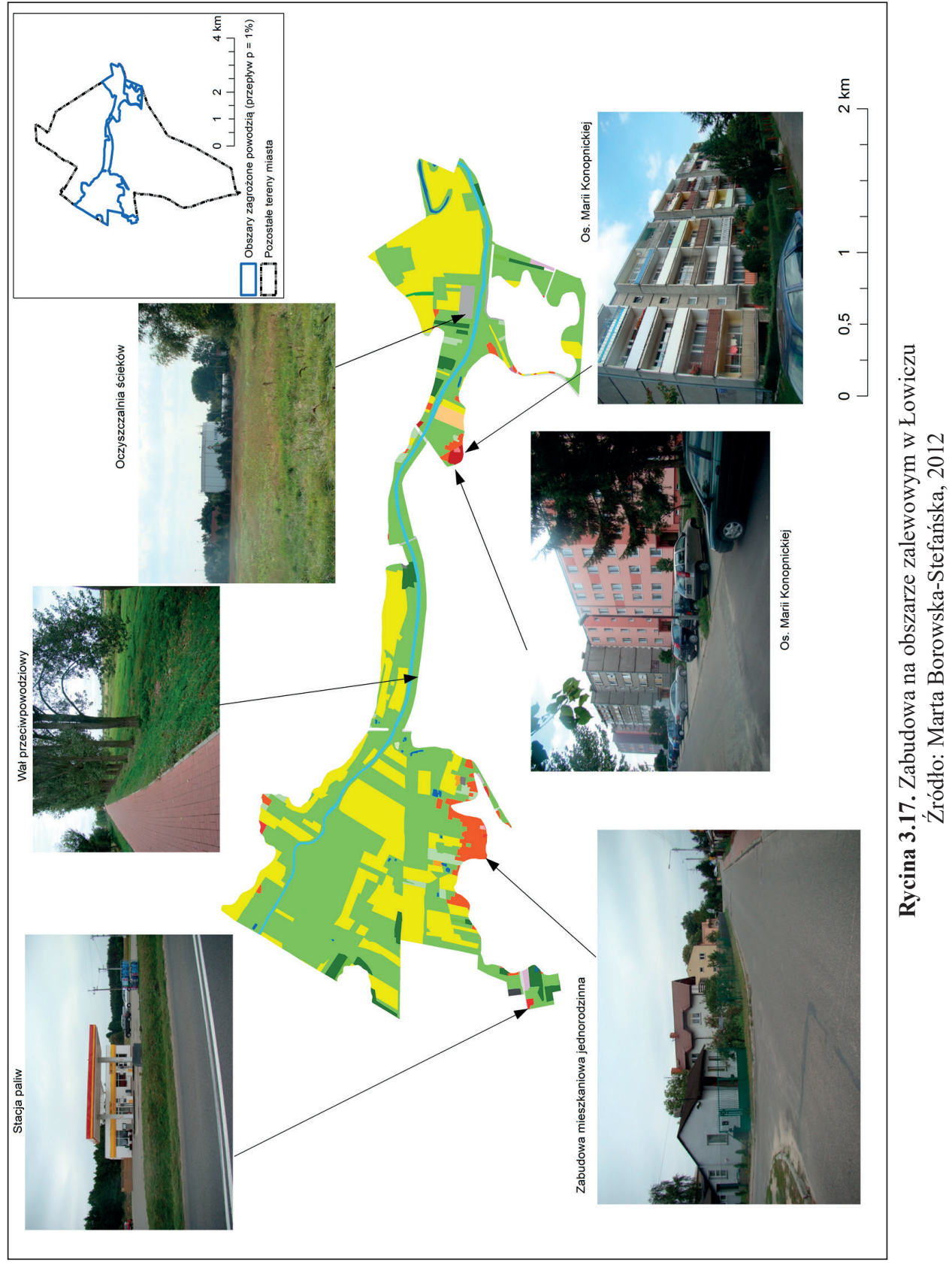




\section{STAN ZAINWESTOWANIA PRZECIWPOWODZIOWEGO W WOJEWÓDZTWIE ŁÓDZKIM}

Najpowszechniejszym środkiem ochrony przeciwpowodziowej zarówno w Polsce, jak i w województwie łódzkim są metody techniczne, a wśród nich obwałowania oraz zbiorniki wodne (Kledyński 2011; Mioduszewski 2012). Dobrze rozwinięty jest również system urządzeń regulacyjnych i hydrotechnicznych.

\subsection{Wały przeciwpowodziowe}

W Polsce obwałowanych jest ok. 8500 km, które chronią łącznie obszar o powierzchni ok. 1093 tys. ha (Borys 2011). Analizując rozmieszczenie obwałowań w układzie wojewódzkim, można stwierdzić, iż najwięcej wałów znajduje się w województwach: dolnośląskim - $1327 \mathrm{~km}$, małopolskim - $1016 \mathrm{~km}$, lubuskim $-815 \mathrm{~km}$, natomiast najmniej w województwie podlaskim $-31 \mathrm{~km}$ (Borys 2007, s. 35).

W województwie łódzkim jest $162 \mathrm{~km}$ wałów przeciwpowodziowych, które chronią obszar 10554 ha, z czego największa ich długość znajduje się wzdłuż rzeki Warty, ponad $100 \mathrm{~km}$ (rycina 4.1). W granicach gmin o bardzo dużym i dużym wskaźniku ryzyka powodziowego ich długość wynosi ok. $133 \mathrm{~km}$ i chronią one obszar 9792 ha. Stanowią je głównie wały lewobrzeżne, zlokalizowane na obszarach wiejskich (tabela 4.1).

Tabela 4.1. Długość wałów przeciwpowodziowych w województwie łódzkim z uwzględnieniem gmin o dużym i bardzo dużym wskaźniku ryzyka powodziowego

\begin{tabular}{|c|c|c|c|c|c|}
\hline \multirow{2}{*}{ Obszar } & \multicolumn{2}{|c|}{$\begin{array}{c}\text { Wał lewobrzeżny } \\
(\mathrm{km})\end{array}$} & \multicolumn{2}{|c|}{$\begin{array}{c}\text { Wał prawobrzeżny } \\
(\mathrm{km})\end{array}$} & $\begin{array}{c}\text { Suma } \\
(\mathrm{km})\end{array}$ \\
\cline { 2 - 6 } & miasto & wieś & miasto & wieś & \\
\hline Gminy & 14,8 & 57,1 & 22,1 & 39,4 & 133,4 \\
\hline Suma & \multicolumn{2}{|c|}{82,5} & \multicolumn{2}{|c|}{79,5} & 162,0 \\
\hline
\end{tabular}

Źródło: opracowanie własne na podstawie danych z WZMiUW, stan na 31.12.2012 r. 


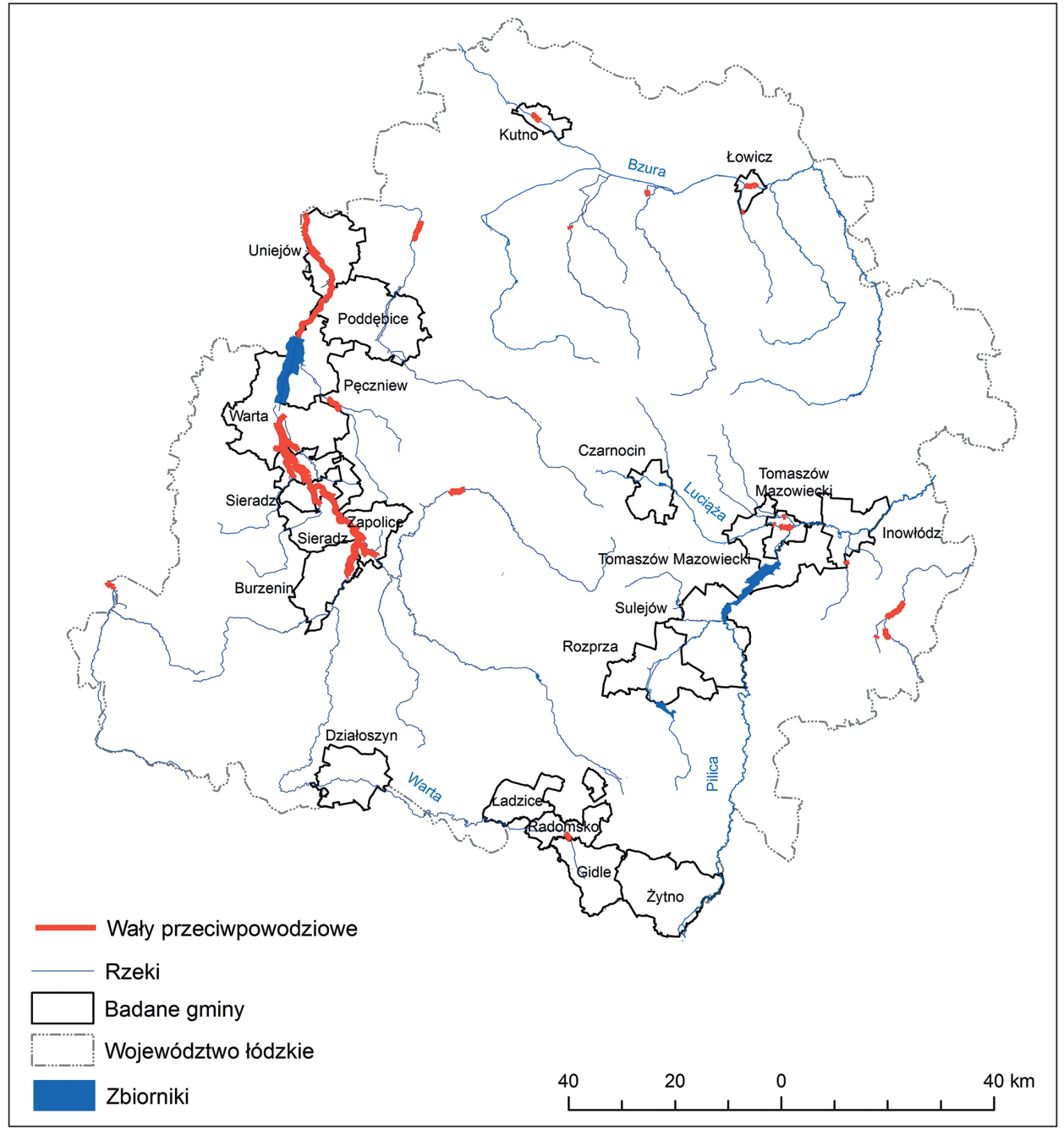

Rycina 4.1. Wały przeciwpowodziowe w województwie łódzkim Źródło: opracowanie własne na podstawie danych WZMiUW, stan na 31.12.2012 r.

Wały przeciwpowodziowe znajdujące się na obszarze województwa łódzkiego są nadzorowane przez Ministerstwo Rolnictwa i Rozwoju Wsi ${ }^{1}$.

1 Obwałowania w Polsce znajdują się w zarządzie jednostek nadzorowanych przez: Ministerstwo Rolnictwa i Rozwoju Wsi - wały użytkowane przez Wojewódzkie Zarządy Melioracji i Urządzeń Wodnych (WZMiUW); Ministerstwo Środowiska - wały użytkowane przez Regionalne Zarządy Gospodarki Wodnej i przez Lasy Państwowe; wojewodów i samorządy - wały użytkowane przez zakłady gospodarki komunalnej, energetykę. W Polsce wały przeciwpowodziowe są zarządzane głównie przez Ministerstwo Rolnictwa i Rozwoju Wsi i administrowane przez Wojewódzkie Zarządy Melioracji i Urządzeń Wodnych. 
Wały przeciwpowodziowe, według rozporządzenia Ministra Środowiska z 20 kwietnia 2007 r. w sprawie warunków technicznych, jakim powinny odpowiadać obiekty budowlane gospodarki wodnej i ich usytuowanie, jako budowle przeznaczone do ochrony przeciwpowodziowej, zaliczane są do jednej z 4 klas budowli hydrotechnicznych ${ }^{2}$ w zależności od wielkości obszaru chronionego danym obwałowaniem, w sposób podany w tabeli 4.2.

Tabela 4.2. Klasyfikacja obwałowań przeciwpowodziowych

\begin{tabular}{|l|c|c|c|c|c|}
\hline \multirow{2}{*}{$\begin{array}{c}\text { Opis i miano } \\
\text { wskaźnika }\end{array}$} & \multicolumn{4}{|c|}{ Wartość wskaźnika dla klasy } & \multirow{2}{*}{ Uwagi } \\
\cline { 2 - 5 } & I & II & III & IV & \\
\hline $\begin{array}{l}\text { Obszar } \\
\text { chroniony } \\
\mathrm{F}\left[\mathrm{km}^{2}\right]\end{array}$ & $\mathrm{F}>300$ & $150<\mathrm{F}<300$ & $10<\mathrm{F} \leq 150$ & $\mathrm{~F} \leq 10$ & $\begin{array}{l}\text { Obszar, który przed obwałowa- } \\
\text { niem ulegał zatopieniu wodami } \\
\text { o prawdopodobieństwie 1\% }\end{array}$ \\
\hline
\end{tabular}

Źródło: Dz.U. 2007, nr 86, poz. 579.

Na obszarze województwa łódzkiego nie występują wały I klasy. W badanych gminach dominują wały klasy II - 110,8 km, najmniej jest wałów pozaklasowych $1,4 \mathrm{~km}$ (rycina 4.2). Wały II klasy zlokalizowane są wzdłuż rzeki Warty i jej dopływów, podobnie jak wały klasy III. Na pozostałym obszarze, tzn. wzdhuż rzeki Ochni, Bzury, Pilicy, znajdują się wały klasy IV, a pozaklasowe na obszarze gminy Radomsko (rycina 4.4).

W przypadku Polski wały I klasy znajdują się na obszarze sześciu województw, przy czym najwięcej jest ich w małopolskim i mazowieckim (Czoch i in. 2011). Większość obwałowań w kraju (86\%) jest zaliczana do II, III i IV klasy (rycina 4.3).

Obwałowania w województwie łódzkim eksploatowane są od bardzo wielu lat, co obrazuje rycina 4.5 . Wałów przeciwpowodziowych o czasie eksploatacji do 20 lat jest ok. $30 \%$, w przedziale $21-40$ lat $-16,5 \%$, od 41 do 60 lat $-6,3 \%$. Większość obwałowań, bo aż 47\% ich łącznej długości, jest eksploatowana ponad 60 lat (rycina 4.6). Sytuacja w przypadku województwa łódzkiego, biorąc pod uwagę stan obwałowań w kraju (rycina 4.7), wydaje się lepsza. Na badanym obszarze nie ma obwałowań eksploatowanych ponad 100 lat.

2 Klasyfikacja obwałowań powinna być dobrana na podstawie dwóch wskaźników charakteryzujących ewentualne szkody, jakie mogłyby powstać w wyniku przerwania wału: liczby ludności przebywającej stale lub czasowo na obszarze chronionym, powierzchni obszaru chronionego (Mackiewicz 2006). W Polsce wały przeciwpowodziowe klasyfikowane są jedynie na podstawie wielkości obszaru chronionego. Nie ma natomiast odniesienia w tej klasyfikacji co do sposobu użytkowania tego terenu, liczby mieszkańców czy infrastruktury, mających wpływ na wielkość ryzyka powodziowego, zdefiniowanego w Dyrektywie Powodziowej (Kledyński 2011). 


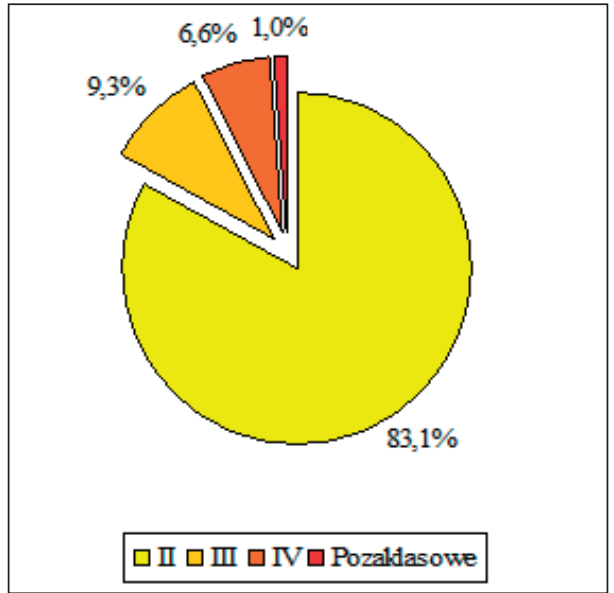

Rycina 4.2. Struktura ilościowa obwałowań w poszczególnych klasach budowli hydrotechnicznych w województwie łódzkim Źródło: opracowanie własne na podstawie danych WZMiUW, stan na 31.12.2012 r.

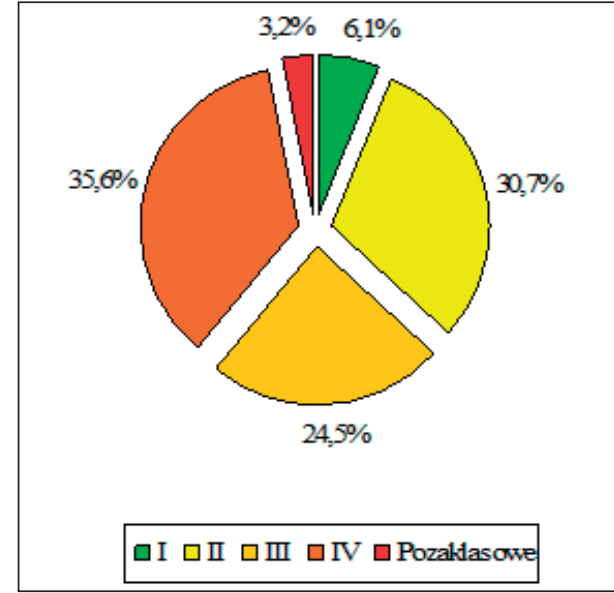

Rycina 4.3. Struktura ilościowa obwałowań w poszczególnych klasach budowli hydrotechnicznych w Polsce Źródło: Czoch i in. (2011).

W Polsce wałów przeciwpowodziowych o czasie eksploatacji do 20 lat jest zaledwie 19\%, natomiast większość wykorzystuje się od ponad 40 lat $(59 \%$ ich łącznej długości). Istnieją również obwałowania, które eksploatowane są od ponad 100 lat (13\%) (Borys 2011), największa ich długość znajduje się na terenie województw: lubuskiego, małopolskiego i pomorskiego (Czoch i in. 2011).

W wyniku tak długiego okresu eksploatacji obwałowań również ich stan techniczny jest niezadowalający i wskazuje na potrzebę ich modernizacji. Wały zgodnie z opublikowanymi przez IMUZ wytycznymi (Procedura 123/7 2008) są klasyfikowane według kategorii stanu technicznego do następujących klas:

1) dobry, niezagrażający bezpieczeństwu;

2) mogący zagrażać bezpieczeństwu;

3) zagrażający bezpieczeństwu³.

3 Podjęcie decyzji o przyporządkowaniu wału do podanych kategorii bezpieczeństwa powinno wynikać z oceny stanu jego zasadniczych elementów. Okresową kontrolą coroczną stanu technicznego, według wytycznych opracowanych na podstawie wiedzy inżynierskiej (Borys, Mosiej 2008; Borys 2013), powinny zostać objęte następujące elementy wałów przeciwpowodziowych: (1) korpus wału, (2) podłoże w terenie przyległym do wału w odległości nie mniejszej niż $10 \mathrm{~m}$ od stopy wału zarówno od strony odwodnej, jak też odpowietrznej, w tym szczególnie na obszarze, na którym w trakcie powodzi zachodzą zjawiska filtracyjne, (3) budowle wałowe towarzyszące, np.: przepusty, śluzy, drenaże, przejazdy wałowe i in., (4) międzywale, zawale oraz obszar chroniony. Dokonywanie ocen stanu technicznego obwałowań w Polsce jest niezadowalające. W latach 1999-2007 dokumentację taką sporządzono dla zaledwie 36\% ogólnej długości wałów. Powodem takiego stanu jest niezadowalający poziom dostępnych środków finansowych. $\mathrm{Z}$ tego względu oceną objęte są przede 


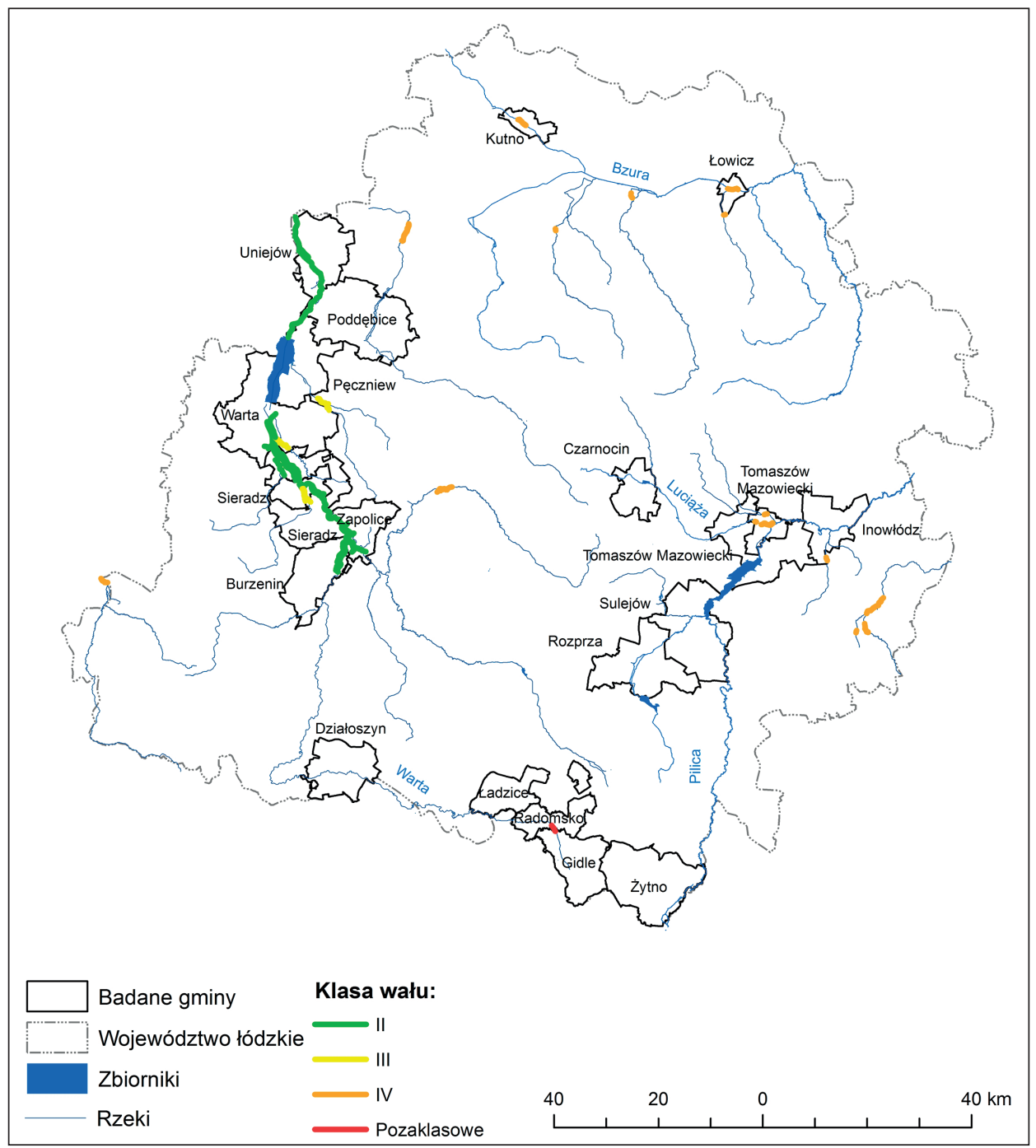

Rycina 4.4. Klasy wałów przeciwpowodziowych w gminach o dużym i bardzo dużym wskaźniku ryzyka powodziowego

Źródło: opracowanie własne na podstawie danych WZMiUW, stan na 31.12.2012 r.

wszystkim wały I i II klasy, natomiast dla wałów III i IV klasy ocena jest dokonywana w momencie konieczności ich modernizacji. Z tego względu na zlecenie MRiRW w latach 2000-2008 prowadzono w IMUZ komputerowy zbiór danych, corocznie aktualizowany dla każdego województwa, który stanowił jedyny kompleksowy zbiór danych o wałach przeciwpowodziowych administrowanych przez WZMiUW (ok. 94\% ogólnej długości wałów) w skali całego kraju. Na jego podstawie sporządzano corocznie raporty o stanie ilościowym i jakościowym wałów zarówno w skali kraju, jak i poszczególnych województw (Borys 2011). 


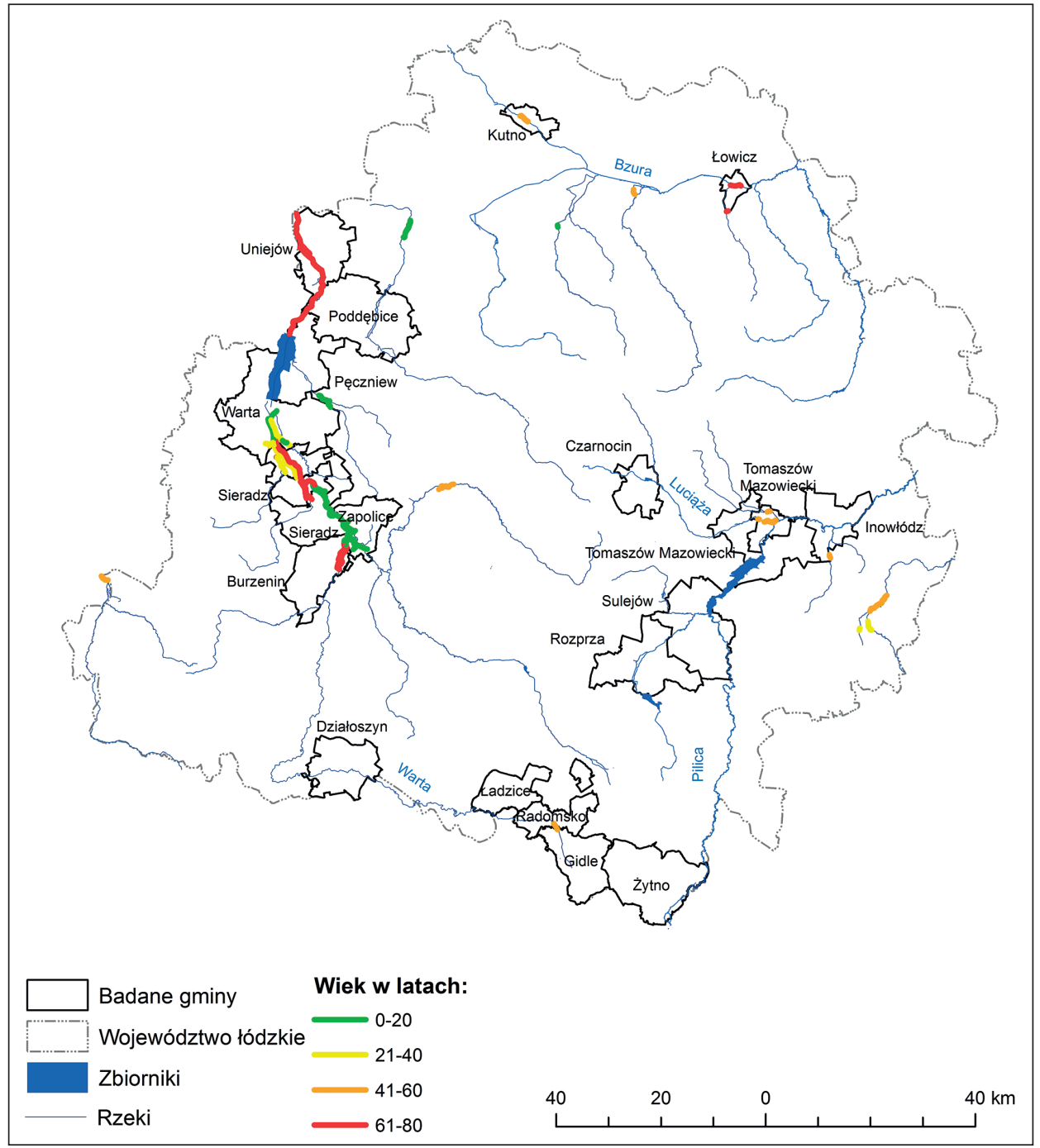

Rycina 4.5. Wiek wałów przeciwpowodziowych w gminach o dużym i bardzo dużym wskaźniku ryzyka powodziowego

Źródło: opracowanie własne na podstawie danych WZMiUW, stan na 31.12.2012 r.

$\mathrm{Na}$ analizowanym obszarze wały przeciwpowodziowe, które nie zagrażają bezpieczeństwu, stanowią ok. 26\%, natomiast takie, które zdecydowanie zagrażają, niecały $1 \%$ ogólnej długości wałów (rycina 4.8).

Niepokojący jest fakt, iż wały mogące zagrażać bezpieczeństwu, chronią duże obszary wzdłuż Warty oraz w mieście Tomaszów Mazowiecki (rycina 4.9). 


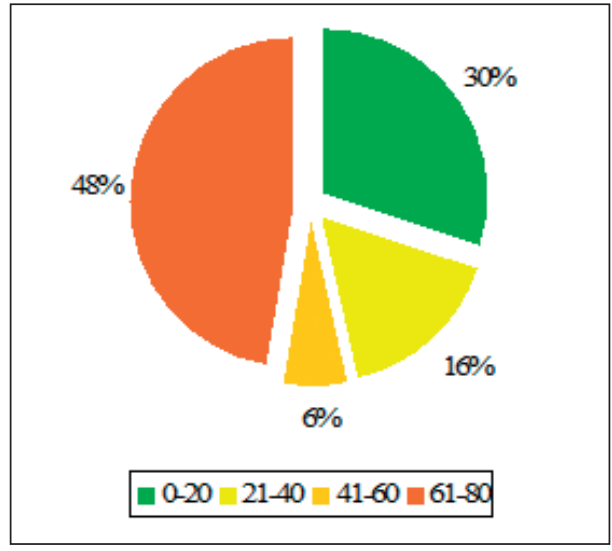

Rycina 4.6. Udział obwałowań o podanym czasie eksploatacji (w latach) w ogólnej długości wałów na obszarze badanych gmin województwa łódzkiego

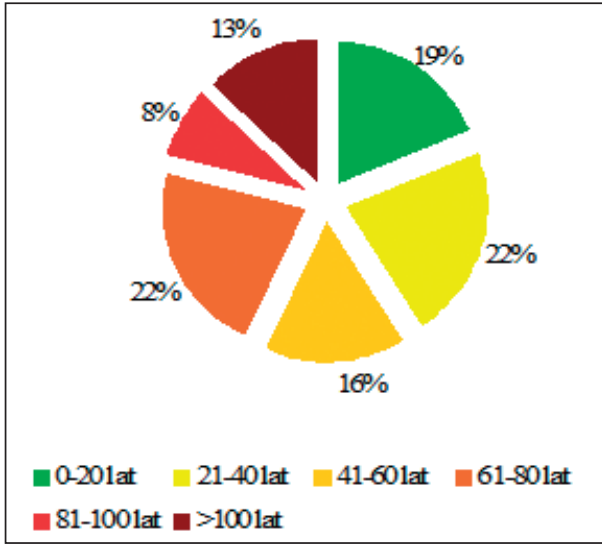

Rycina 4.7. Udział obwałowań o podanym czasie eksploatacji (w latach) w ogólnej długości wałów w Polsce

Źródło: Raport... (2008), stan na 31.12. 2007 r.

Źródło: opracowano na podstawie danych

WZMiUW, stan na 31.12.2012 r.

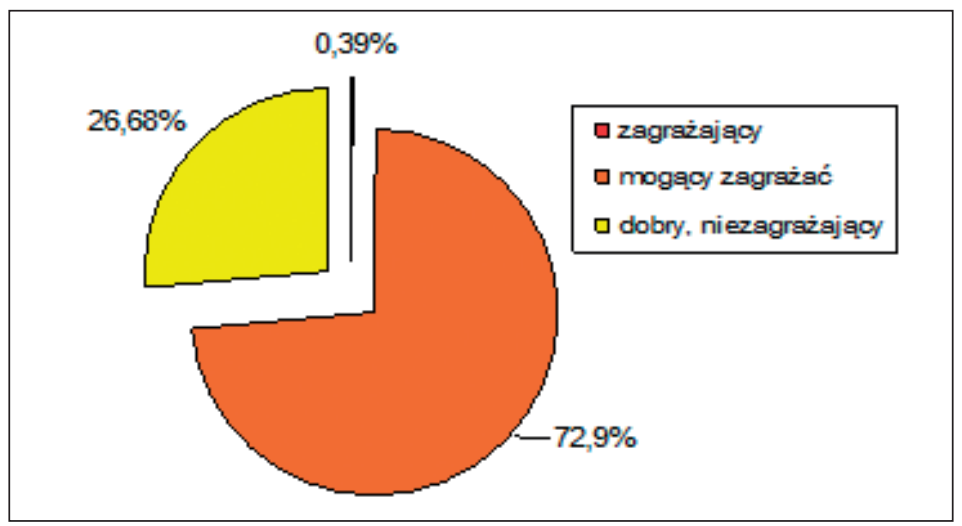

Rycina 4.8. Stan bezpieczeństwa wałów przeciwpowodziowych na obszarze badanych gmin województwa łódzkiego

Źródło: opracowano na podstawie danych WZMiUW, stan na 31.12.2012 r.

W 2007 r. w Polsce 8\% łącznej długości wałów było w stanie zagrażającym bezpieczeństwu, natomiast ok. 27\% w stanie mogącym zagrażać bezpieczeństwu (Borys 2011) ${ }^{4}$. Do najczęściej występujących przyczyn złego stanu technicznego obwałowań na obszarze badanych gmin można zaliczyć:

${ }^{4} \mathrm{Na}$ stan techniczny wałów przeciwpowodziowych ma wpływ ich utrzymanie, które polega na wykonywaniu bieżących prac konserwacyjnych. Ich koszt pokrywany jest głównie ze środków 
- brak wymaganego stopnia zagęszczenia;

- lokalne przesiąki;

- lokalne występowanie kretowisk;

- niewłaściwe wymiary geometryczne wału,

- różną wysokość wału;

- za niską koronę wału dla wody miarodajnej (WZMiUW 2012).

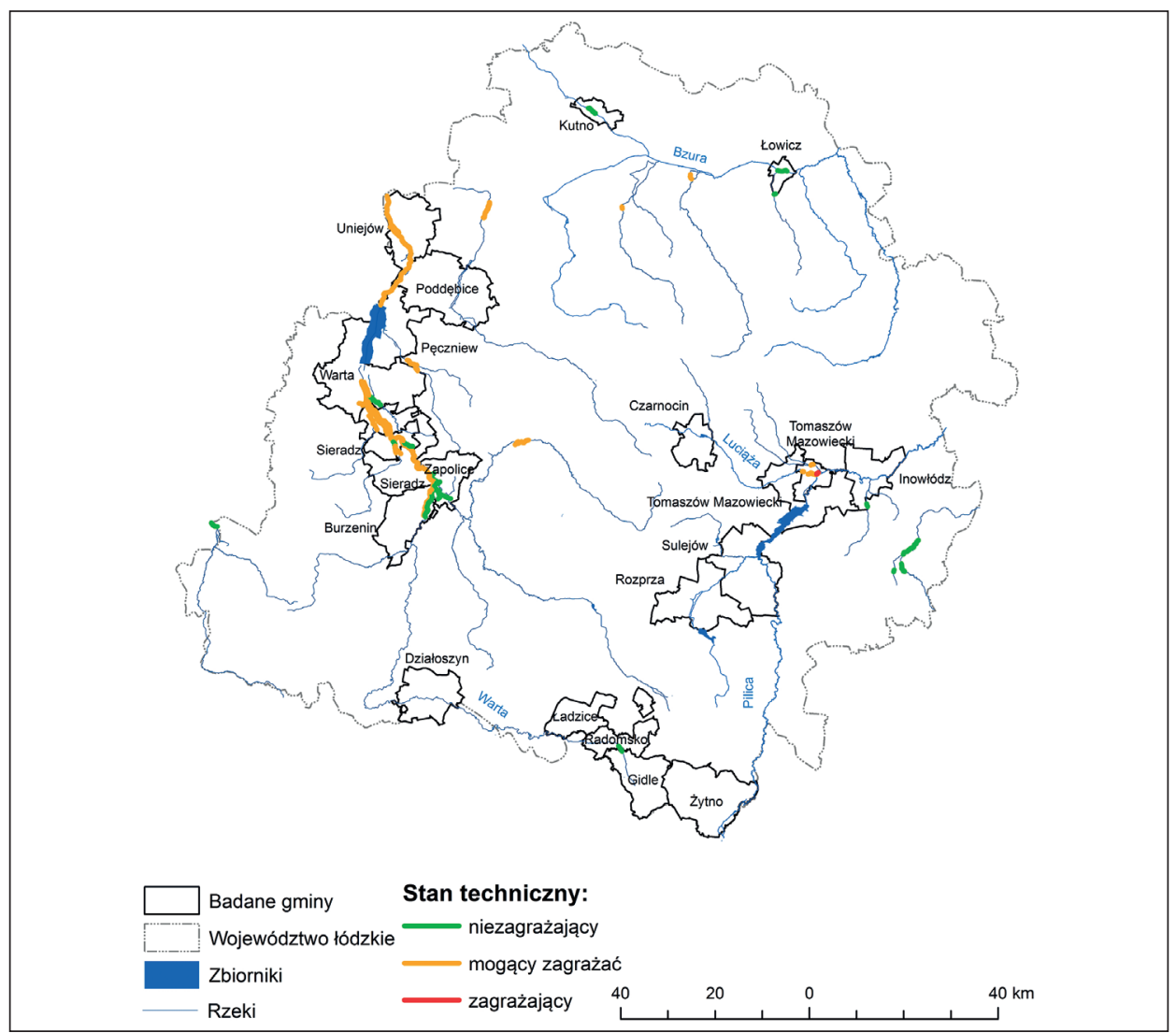

Rycina 4.9. Wały przeciwpowodziowe według stanu technicznego w gminach o dużym i bardzo dużym wskaźniku ryzyka powodziowego

Źródło: opracowanie własne na podstawie danych WZMiUW, stan na 31.12.2012 r.

budżetowych. Niewystarczająca ilość środków finansowych przekazywana zarządcom przyczynia się do ich dalszej degradacji. Analizując poziom utrzymania obwałowań w latach 1998-2007, można wyróżnić kilka etapów. Od 1998 r. do 2001 r. poziom ten zmniejszał się systematycznie, od ok. $89 \%$ do $58,2 \%$. W 2002 r. wzrósł on nieznacznie do $64,7 \%$ i w kolejnych latach utrzymywał się na poziomie 62-67\% (2007 r.) (Raport... 2008). „Powodzie w 2010 r. wykazały, że zbyt mało uwagi zwraca się na modernizację i utrzymanie obwałowań. Brak bieżącej konserwacji i niewłaściwa eksploatacja są jedną z najczęstszych przyczyn osłabienia wałów, w tym ich niszczenia przez bobry" (Mioduszewski 2010, s. 152). 
Stan techniczny wałów przeciwpowodziowych w województwie łódzkim jest nieco lepszy w porównaniu do całego kraju, jednak wciąż nie do końca zadowalający, w związku z brakiem funduszy na ich modernizację.

\subsection{Zbiorniki retencyjne}

Województwo łódzkie położone jest na wododziale I-rzędu pomiędzy dorzeczem Wisły i Odry. Obszar ten jest ubogi w wody powierzchniowe, na co wpływ ma przede wszystkim niewielka liczba dużych cieków, prowadzących znaczne ilości wody (Warta, Pilica, Bzura, znajdują się na jego peryferiach) oraz brak większych naturalnych zbiorników. Retencjonowanie wody odbywa się w niezbyt licznych, sztucznych zbiornikach zaporowych, zespołach stawów rybnych, niewielkich zbiornikach naturalnych oraz sztucznych, jak też na terenach bagiennych. Ogólna powierzchnia wód stojących na terenie województwa łódzkiego szacowana jest na ok. 10770 ha (wraz z uwzględnieniem oczek wodnych o powierzchni $>0,01 \mathrm{ha}$ ). Ponad połowa tej powierzchni przypada na dwa największe, sztuczne zbiorniki znajdujące się w województwie (w granicach badanych gmin) - Jeziorsko na rzece Warcie (4230 ha) oraz Sulejów na Pilicy (1980 ha) - tabela 4.3 (Wojewódzki program matej retencji... 2005).

Tabela 4.3. Zbiorniki wodne w województwie łódzkim

\begin{tabular}{|c|c|c|c|c|c|}
\hline $\begin{array}{c}\text { Powierzchnia } \\
\text { zbiornika } \\
{[\mathrm{Ha}]}\end{array}$ & $\begin{array}{c}\text { Liczba } \\
\text { zbiorników } \\
{[\text { szt. }]}\end{array}$ & $\begin{array}{c}\text { Suma } \\
\text { powierzchni } \\
{[\mathrm{ha}]}\end{array}$ & $\begin{array}{c}\text { Udział ogólnej } \\
\text { powierzchni } \\
\text { wód stojących } \\
{[\%]}\end{array}$ & $\begin{array}{c}\text { Średnia } \\
\text { głębokość } \\
{[\mathrm{m}]}\end{array}$ & $\begin{array}{c}\text { Szacunkowa suma } \\
\text { pojemności } \\
{\left[\mathrm{m}^{3}\right]}\end{array}$ \\
\hline $\mathrm{F}>1000$ & 2 & 6017 & 55,9 & 4 & 281,6 \\
\hline $1000>\mathrm{F}>50$ & 12 & 1107,1 & 10,3 & 2,5 & 27,7 \\
\hline $50>\mathrm{F}>5$ & 139 & 1694,4 & 15,7 & 1,5 & 25,4 \\
\hline $5>\mathrm{F}>1$ & 397 & 857,9 & 8,0 & 1,0 & 8,6 \\
\hline $1>\mathrm{F}>0,1$ & 3732 & 1004,1 & 9,3 & 0,8 & 8,0 \\
\hline $0,1>\mathrm{F}>0,01$ & 1193 & 90,1 & 0,8 & 0,5 & 0,4 \\
\hline Suma & 5475 & 10770,6 & 100 & - & 359,4 \\
\hline
\end{tabular}

Źródło: Wojewódzki program małej retencji dla województwa tódzkiego (2005).

Do zbiorników wodnych, mających istotny wpływ na sytuację hydrologiczną na obszarze województwa łódzkiego, poza dwoma największymi, zalicza się:

- zbiornik Cieszanowice na rzece Luciąży - gmina Gorzkowice, Rozprza i Łęki Szlacheckie (zarządzany przez WZMiUW w Łodzi, zrealizowany w ramach programu małej retencji); 
- zbiornik Miedzna na rzece Wąglance - gmina Białaczów i Żarnów (zarządzany przez WZMiUW w Lodzi);

- zbiornik Słok na rzece Widawce (powierzchnia 80 ha);

- zbiornik Wawrzkowizna na rzece Widawce (powierzchnia 18,13 ha);

- zbiornik Zadębie na rzece Skierniewce (powierzchnia 25,7 ha);

- zbiornik Bugaj na rzece Wierzejka (powierzchnia $52 \mathrm{ha}$ );

- zbiornik Rydwan na rzece Bobrówka (powierzchnia 64 ha);

- zbiornik Okręt na rzece Bobrówka (powierzchnia 172,5 ha);

- zbiornik Czarnocin I i II na rzece Wolbórce - gmina Czarnocin (zarządzany przez WZMiUW w Lodzi, zrealizowany w ramach programu małej retencji) (Plan operacyjny... 2013; Wojewódzki program małej retencji... 2005).

$\mathrm{W}$ granicach gmin o dużym i bardzo dużym wskaźniku ryzyka powodziowego znajdują się 4 istotne z punktu widzenia ochrony przeciwpowodziowej zbiorniki: Jeziorsko, Sulejów, Cieszanowice i Czarnocin I i II (rycina 4.10).

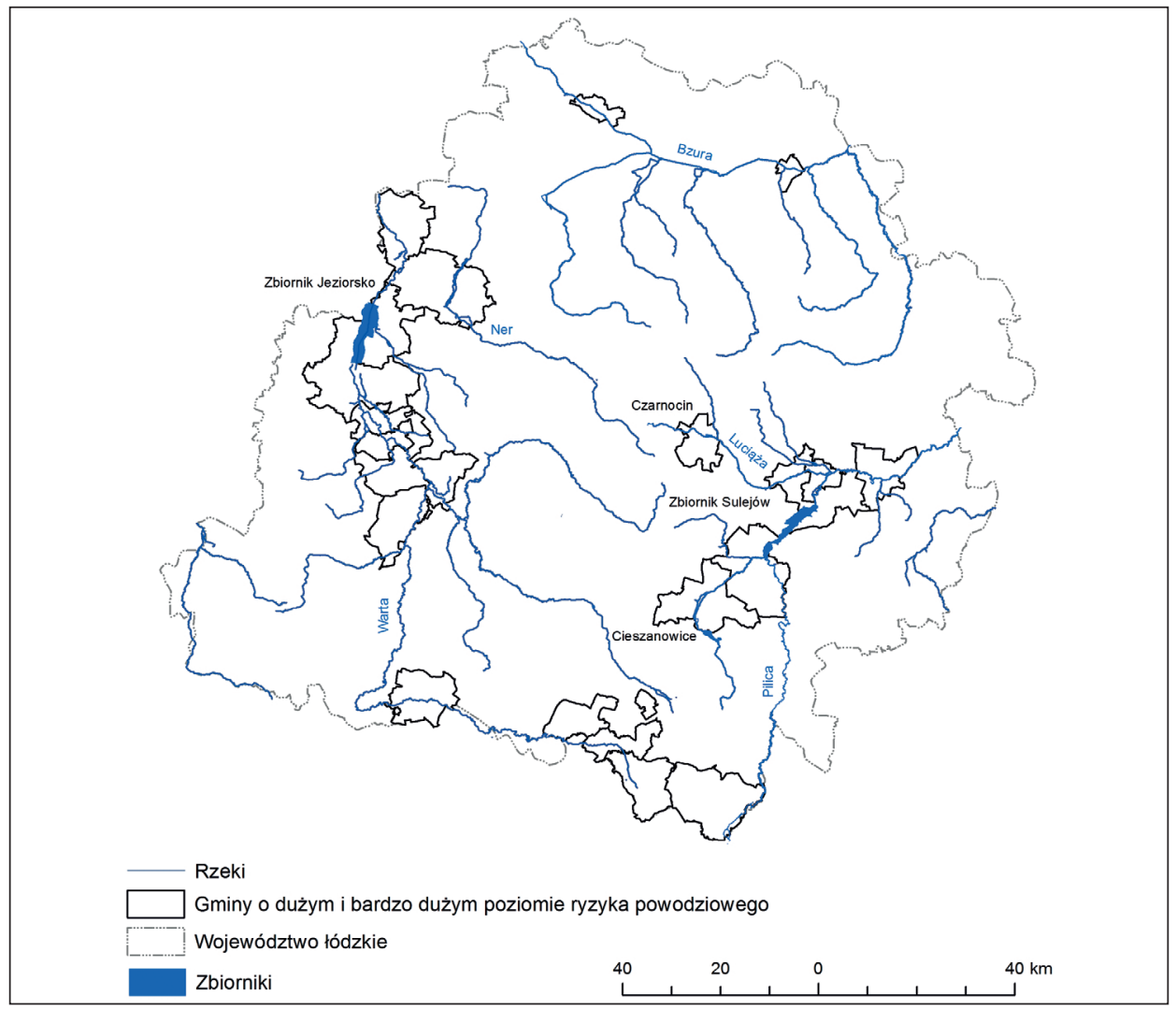

Rycina 4.10. Zbiorniki istotne z punktu widzenia ochrony przeciwpowodziowej w granicach gmin województwa łódzkiego o dużym i bardzo dużym wskaźniku ryzyka powodziowego Źródło: opracowanie własne na podstawie danych WZMiUW, stan na 31.12.2012 r. 
Zbiorniki poza funkcją ochrony przeciwpowodziowej (tabela 4.4), stwarzają również potencjalne zagrożenie w przypadku przerwania zapór, w tym głównie:

- zbiornik Jeziorsko - w trakcie przejścia fali powodziowej przy nadzwyczajnym poziomie piętrzenia może dojść do niekontrolowanego przelewu wody przez zaporę i jej lokalne rozmycie, połączone z nagłym opróżnieniem całego zbiornika, zniszczeniem wału przeciwpowodziowego poniżej zapory. W wyniku tego na zalanie narażona jest lewobrzeżna dolina rzeki Warty od zapory do istniejącego wału poprzecznego w Radyczynach poniżej Uniejowa (ok. $60 \mathrm{~km}^{2}$ ) oraz 7 km drogi Turek-Uniejów-Łódź. W obrębie potencjalnego zalewu znajdują się zabudowania kilkunastu wsi;

- zbiornik Sulejów - w wyniku uszkodzenia zapory wodnej w miejscowości Smardzewice (zapora jest zlokalizowana $8 \mathrm{~km}$ od miasta Tomaszów Mazowiecki), przy założeniu maksymalnej wysokości piętrzenia wody w zbiorniku (167 m n.p.m.) istnieje prawdopodobieństwo, że fala dotrze do Tomaszowa Mazowieckiego i zaleje miasto oraz gminę na powierzchni $20 \mathrm{~km}^{2}$;

- zbiornik Cieszanowice - awaria zapory czołowej stwarza potencjalne zagrożenie w dolinie rzeki Luciąży, na odcinku $12 \mathrm{~km}$ od osi zapory do rejonu wsi Ignaców i Bagno (Plan operacyjny... 2013).

Tabela 4.4. Parametry zbiorników wodnych zlokalizowanych $\mathrm{w}$ gminach województwa łódzkiego o dużym i bardzo dużym wskaźniku ryzyka powodziowego

\begin{tabular}{|l|c|c|c|}
\hline \multicolumn{1}{|c|}{ Nazwa zbiornika } & $\begin{array}{c}\text { Powierzchnia } \\
{[\mathrm{ha}]}\end{array}$ & $\begin{array}{c}\text { Pojemność całkowita } \\
{\left[\mathrm{m}^{3}\right]}\end{array}$ & $\begin{array}{c}\text { Rezerwa } \\
\text { powodziowa } \\
{\left[\mathrm{m}^{3}\right]}\end{array}$ \\
\hline Zbiornik Jeziorsko & 4230 & $202,04 \mathrm{mln}$ & $39,75 \mathrm{mln}$ \\
\hline Zbiornik Sulejów & 1980 & $60,263 \mathrm{mln}$ & $9,22 \mathrm{mln}$ \\
\hline Zbiornik Cieszanowie & 217 & $7,34 \mathrm{mln}$ & $1,76 \mathrm{mln}$ \\
\hline Zbiornik Czarnocin I i II & 32,5 & 500 tys. & $0,174 \mathrm{mln}$ \\
\hline
\end{tabular}

Źródło: Plan operacyjny ochrony przed powodzia dla województwa łódzkiego (2013).

W celu zapewnienia właściwej pracy zbiornika retencyjnego należy równoważyć funkcje środowiskowe i ochrony przed powodzią, co często jest zadaniem niezwykle trudnym. W 1998 r. w górnej części zbiornika Jeziorsko, zgodnie z rozporządzeniem Ministra Środowiska Zasobów Naturalnych i Leśnictwa z 23 grudnia 1998 r., został utworzony rezerwat przyrody „Jeziorsko”. Celem ochrony tego rezerwatu jest zachowanie ze względów naukowych, dydaktycznych i krajobrazowych ostoi ptaków wodno-błotnych, w tym licznie występujących gatunków ptaków rzadkich oraz chronionych. W 2008 r. rezerwat „Jeziorsko” wraz z terenami przyległymi (Ługi Glińskie) został uwzględniony na liście utworzonych ostoi ptaków o znaczeniu międzynarodowym, które wyznaczono jako obszary 
specjalnej ochrony ptaków (OSOP) w sieci Natura 2000. W związku z tym istotnym celem gospodarki prowadzonej na obiekcie jest zapewnienie odpowiednich warunków siedliskowych dla ptaków wodnych. Istniejący rezerwat ornitologiczny uniemożliwia wykonywanie jakichkolwiek prac mających na celu zmianę kształtu brzegów i dna zbiornika, w tym regulacji, wycinania drzew, bagrowania itp. Utworzenie rezerwatu przyrody oraz brak prac bagrowniczych doprowadziły do intensywnego i niekontrolowanego zamulania i zarastania zbiornika, w wyniku czego może dojść do katastrofy, w postaci przerwania wałów. Sytuacji tej zapobiec może jedynie odstępstwo od reguł ustanowionych dla funkcjonowania rezerwatu, umożliwiające wykonanie prac zapobiegawczych (Wicher-Dysarz, Dysarz 2007). Nie można zapominać, że zbiornik został utworzony początkowo do pełnienia przede wszystkim funkcji ochrony przeciwpowodziowej poprzez redukcję kulminacji fali powodziowej.

Retencja w zlewniach rzek województwa łódzkiego odbywa się również przy wykorzystaniu małych zbiorników. Występują one w dużej ilości i lokalizowane są głównie w rejonie wododziałów, dzięki czemu możliwe jest zachowanie równowagi środowiska. Zbiorniki małej retencji pełnić mogą różnorodne funkcje, głównie przyrodnicze, rekreacyjne, w mniejszym stopniu gospodarcze. Zbiorniki małej oraz średniej wielkości, zamykające zlewnie 3-4 rzędnych dopływów, spełniają szczególną rolę w ochronie przeciwpowodziowej. Na małych rzekach w trakcie gwałtownych opadów lub roztopów następuje szybkie wezbranie, co stwarza istotne zagrożenie dla dolin, w szczególności intensywnie użytkowanych, zamieszkałych przez ludzi. W granicach badanych gmin programowanych jest łącznie 26 obiektów małej retencji, które pełnić będą głównie funkcję przeciwpowodziową. Zbiorniki o powierzchni poniżej 0,5 ha znajdować się będą w zlewni rzeki Warty, natomiast o powierzchni powyżej 0,5 ha, w zlewni rzeki Warty, Pilicy oraz Bzury.

Najwięcej obiektów małej retencji ma powstać na obszarze gmin Uniejów, Poddębice, Gidle, Radomsko, Sieradz, Czarnocin, Tomaszów Mazowiecki (Wojewódzki program małej retencji... 2005). 


\section{ROZKLAD RYZYKA POWODZIOWEGO W WOJEWÓDZTWIE LÓDZKIM - KONTEKST ZAGOSPODAROWANIA}

\subsection{Kategorie ryzyka powodziowego}

Analiza aktualnego zagospodarowania terenów szczególnego zagrożenia powodziami w badanych gminach województwa łódzkiego wykazała, że dominującą grupę stanowią tereny wolne od zabudowy. Największa pozioma intensywność zagospodarowania terenów zalewowych cechuje gminy miejskie, położone w dorzeczu Wisły - Tomaszów Mazowiecki, Kutno i Łowicz. W pozostałych gminach zabudowa stanowi niewielki udział, jednak mimo tego rejestrowane są straty powstałe na skutek powodzi. Dlatego też niezwykle istotnym zagadnieniem jest ocena ryzyka powodziowego w granicach terenów zalewowych oraz wprowadzenie zakazu dalszej zabudowy. We wszystkich wydzielonych kategoriach ryzyka określono powierzchnię zajmowaną przez obiekty i tereny zaklasyfikowane do określonych grup, a w przypadku strat ekonomicznych ich wielkość (tabela 5.1).

\section{Obiekty spoleczne}

Obiekty, w których czasowo lub stałe mogą przebywać ludzie, zajmują łącznie ok. 14 ha w granicach terenów zalewowych. Największą ich powierzchnię zinwentaryzowano w gminach: Gidle, Tomaszów Mazowiecki (miasto) oraz Łowicz. Budynki mieszkalne lokalizowane są głównie w miejscach, gdzie równina zalewowa jest szeroka lub też w dolinach mniejszych rzek. Na obszarze dwóch gmin - Warta i Zapolice, w granicach terenów zagrożonych powodziami, obiekty $\mathrm{z}$ tej kategorii nie występują. Istnieją tam wały przeciwpowodziowe, w wyniku których analizowany teren wody 100-letniej został znacząco zawężony w stosunku do całego obszaru zalewowego. W badanych gminach dominowała zabudowa mieszkaniowa jednorodzinna. Budynki wielorodzinne zlokalizowane są w Łowiczu (osiedle bloków). Do omawianej grupy zaliczono również szpital powiatowy 
Tabela 5.1. Kategorie ryzyka powodziowego według powierzchni i wielkości strat w granicach wody $1 \%$ badanych gmin województwa łódzkiego

\begin{tabular}{|c|c|c|c|c|c|c|}
\hline Zlewnia & Gminy & $\begin{array}{c}\text { Powierzchnia } \\
\text { terenu } \\
\text { szczególnego } \\
\text { zagrożenia } \\
\text { powodzią } \\
\text { [ha] }\end{array}$ & $\begin{array}{c}\text { Obiekty } \\
\text { o znaczeniu } \\
\text { społecznym } \\
{[\text { ha] }}\end{array}$ & $\begin{array}{c}\text { Obiekty } \\
\text { dziedzictwa } \\
\text { kulturowego } \\
\text { tereny cenne } \\
\text { przyrodniczo } \\
\text { [ha] }\end{array}$ & $\begin{array}{c}\text { Obiekty } \\
\text { zagrażające } \\
\text { środowisku } \\
\text { oraz } \\
\text { ludziom } \\
\text { [ha] } \\
\end{array}$ & $\begin{array}{c}\text { Wielkość } \\
\text { strat } \\
\text { [tys. zł] }\end{array}$ \\
\hline \multirow{12}{*}{ Warty } & Gidle & 3625,09 & 3,68 & 1,35 & 0,42 & 92060,4 \\
\hline & Radomsko & 1242,42 & 1,26 & - & - & 29755,75 \\
\hline & Ładzice & 189,45 & 0,05 & - & - & 4339,74 \\
\hline & Działoszyn & 726,09 & 0,55 & 283,56 & 1,43 & 43357,1 \\
\hline & Burzenin & 690,68 & 0,05 & 580,47 & - & 3273,69 \\
\hline & Zapolice & 953,63 & - & 56,11 & 0,39 & 2030,98 \\
\hline & $\begin{array}{l}\text { Sieradz } \\
\text { (gmina } \\
\text { wiejska) }\end{array}$ & 2513,11 & 0,33 & 409,00 & - & 9574,01 \\
\hline & $\begin{array}{l}\text { Sieradz } \\
\text { (miasto) }\end{array}$ & 740,17 & 0,37 & 2,93 & - & 18342,73 \\
\hline & Warta & 1919,37 & - & 1919,37 & 0,31 & 1472,29 \\
\hline & Pęczniew & 2278,94 & 0,42 & 1901,5 & - & 13571,19 \\
\hline & Poddębice & 3671,87 & 1,20 & 492,10 & 1,36 & 49186,98 \\
\hline & Uniejów & 729,42 & 0,61 & 729,42 & - & 19588,42 \\
\hline \multirow{7}{*}{ Pilicy } & Żytno & 969,48 & 0,21 & 969,48 & - & 5229,76 \\
\hline & Rozprza & 902,27 & 0,17 & - & - & 26600,8 \\
\hline & Sulejów & 1022,29 & 0,19 & 754,70 & - & 8486,48 \\
\hline & Czarnocin & 321,67 & 0,03 & - & - & 937,39 \\
\hline & $\begin{array}{l}\text { Tomaszów } \\
\text { Mazowiecki } \\
\text { (gmina } \\
\text { wiejska) }\end{array}$ & 1583,8 & 0,56 & 969,61 & 0,40 & 43054,91 \\
\hline & $\begin{array}{l}\text { Tomaszów } \\
\text { Mazowiecki } \\
\text { (miasto) }\end{array}$ & 761,59 & 1,72 & 86,32 & 41,83 & 301285,99 \\
\hline & Inowłódz & 828,40 & 0,26 & 739,97 & . & 9986,19 \\
\hline \multirow{3}{*}{ Bzury } & Kutno & 292,6 & 0,94 & - & 1,28 & 42863,91 \\
\hline & Lowicz & 396,24 & 1,36 & 189,63 & 3,27 & 32626,75 \\
\hline & Suma & 26358,58 & 13,96 & 10085,52 & 50,68 & 757625,5 \\
\hline
\end{tabular}

Objaśnienia: (-) zjawisko nie występuje; (.) zjawisko występowało w wielkości mniejszej od 0,01 ha.

Źródło: opracowanie własne, 2013. 
(gmina Gidle), szkoły (gmina oraz miasto Tomaszów Mazowiecki, Radomsko), przedszkole (Łowicz), hotele (Uniejów, Rozprza, miasto Sieradz, Inowłódz), Instytut Zdrowia (Uniejów). Znaczne powierzchnie obiektów społecznych występują w dorzeczu Wisły, w szczególności w gminach miejskich (Tomaszów Mazowiecki, Łowicz, Kutno).

\section{Obiekty dziedzictwa kulturowego oraz tereny cenne przyrodniczo}

W grupie obiektów dziedzictwa kulturowego oraz terenów cennych przyrodniczo dominują tereny chronione. Zajmują one największą powierzchnię spośród wszystkich wyodrębnionych kategorii - ok. 10085 ha. Tereny chronione znajdują się głównie w gminach wiejskich oraz miejsko-wiejskich: Uniejów (obszar Natura 2000), Żytno (Natura 2000 - obszar siedliskowy), Warta (rezerwat przyrody „Jeziorsko”, Natura 2000 - obszary ptasie), Inowłódz (Spalski Park krajobrazowy, Natura 2000 - obszar siedliskowy), Burzenin (Park Krajobrazowy Międzyrzecza Warty i Widawki), Pęczniew (rezerwat przyrody „Jeziorsko”, Natura 2000 - obszary ptasie), Sulejów (Sulejowski Park Krajobrazowy), gmina Tomaszów Mazowiecki (Sulejowski oraz Spalski Park Krajobrazowy, Natura 2000 - obszary siedliskowe). Do tej kategorii zaliczono również obiekty dziedzictwa kulturowego, tj. park etnograficzny, Wzgórze Zamkowe (miasto Sieradz), Skansen Rzeki Pilicy (miasto Tomaszów Mazowiecki), ogród zoologiczny (Poddębice), zamek uniejowski, zagrodę młynarską (Uniejów), zabytkową synagogę (Inowłódz).

\section{Obiekty potencjalnie zagrażające środowisku przyrodniczemu oraz ludziom}

Obiekty generujące potencjalne negatywne konsekwencje dla środowiska przyrodniczego i ludzi w badanych gminach zajmują łącznie powierzchnię ok. 50 ha. W ramach tej grupy dominują oczyszczalnie ścieków oraz stacje paliw. Oczyszczalnie zidentyfikowano w granicach wody 1\% w sześciu gminach: Działoszyn, Inowłódz, Łowicz, Tomaszów Mazowiecki (miasto), Poddębice, Warta. Stacje paliw zostały zlokalizowane na terenach zalewowych dwóch gmin: Działoszyn i Łowicz (miasto). Największą powierzchnię obiektów stwarzających potencjalne zagrożenia dla środowiska przyrodniczego oraz ludzi zinwentaryzowano w granicach Tomaszowa Mazowieckiego (miasta), Łowicza, Działoszyna, Poddębic i Kutna. Obiekty zaliczone do tej kategorii znacznie częściej występują w granicach wody $1 \% \mathrm{w}$ miastach oraz tam, gdzie nie istnieją wały przeciwpowodziowe, a dna dolin rzecznych są szerokie. 


\section{Straty ekonomiczne}

Największa potencjalna wartość strat liczonych w złotówkach przypada na miasto Tomaszów Mazowiecki i wynosi 301 285,99 tys. zł. W granicach terenów zalewowych występuje tam największa pozioma intensywność użytkowania. Na wielkość strat wpływ mają przede wszystkim zakłady produkcyjne i usługowe, zlokalizowane wzdłuż rzeki Czarnej i Piasecznicy (łączna wielkość strat 148 505,85 tys. zł), oraz oczyszczalnia ścieków (137 429,29 tys.zł). W gminie Gidle i Poddębice straty materialne mogą wynosić odpowiednio 92060,4 i 49 186,98 tys. zł. Jest to związane ze znaczną powierzchnią zabudowy mieszkaniowej w granicach zalewu. Najmniejsze potencjalne straty zidentyfikowano w gminie Czarnocin.

\section{Zróżnicowanie kategorii ryzyka powodziowego}

Ze względu na znaczne różnice w powierzchni obszarów szczególnego zagrożenia powodziami w analizowanych gminach obliczono udział obiektów i terenów przypisanych do poszczególnych kategorii ryzyka powodziowego, a także wielkość strat w zł/ $/ \mathrm{m}^{2}$ (tabela 5.2). Największy udział obiektów o znaczeniu społecznym występuje w gminach miejskich, położonych w dorzeczu Wisły - w Łowiczu, Kutnie i Tomaszowie Mazowieckim (mieście). W ich granicach ekspansja zabudowy następuje w szczególności nad mniejszymi rzekami.

Tereny cenne przyrodniczo i obiekty dziedzictwa kulturowego stanowią największy udział w gminach wiejskich lub miejsko-wiejskich. Obiekty stwarzające potencjalne zagrożenie dla środowiska przyrodniczego i ludzi w przypadku nadejścia powodzi zostały zidentyfikowane głównie w gminach miejskich, dorzecza Wisły.

Obiekty i tereny, zaliczone do poszczególnych kategorii ryzyka powodziowego nie występują we wszystkich gminach. W sześciu z nich zidentyfikowano wszystkie kategorie ryzyka powodziowego na terenach zalewowych (tabela 5.3). Szczególnym przypadkiem jest miasto Łowicz (rycina 5.1), gdzie udział obiektów i terenów (czy też wartość w zł/ $/ \mathrm{m}^{2}$ ) we wszystkich przypadkach przekracza średnią arytmetyczną dla badanych gmin. Na obszarach zalewowych w gminie Czarnocin, Ładzice, Rozprza oraz Żytno nie występują obiekty dziedzictwa kulturowego czy też tereny chronione oraz nie zlokalizowano tam obiektów mogących zagrażać środowisku przyrodniczemu i ludziom, a w pozostałych dwóch klasach wartość nie przekracza średniej arytmetycznej dla wszystkich gmin. 
Tabela 5.2. Udział obiektów i terenów poszczególnych kategorii ryzyka powodziowego oraz wielkość strat $\mathrm{w} \mathrm{zł} / \mathrm{m}^{2} \mathrm{w}$ granicach wody 100-letniej badanych gmin województwa łódzkiego

\begin{tabular}{|c|c|c|c|c|c|c|}
\hline Zlewnia & Gminy & $\begin{array}{c}\text { Powierzchnia } \\
\text { terenu } \\
\text { szczególnego } \\
\text { zagrożenia } \\
\text { powodzią } \\
\text { [ha] }\end{array}$ & $\begin{array}{c}\text { Obiekty } \\
\text { o znaczeniu } \\
\text { społecznym } \\
{[\%]}\end{array}$ & $\begin{array}{c}\text { Obiekty } \\
\text { dziedzictwa } \\
\text { kulturowego } \\
\text { i tereny } \\
\text { cenne } \\
\text { przyrodniczo } \\
{[\%]} \\
\end{array}$ & $\begin{array}{c}\text { Obiekty } \\
\text { zagrażające } \\
\text { środowisku } \\
\text { oraz } \\
\text { ludziom } \\
\text { [\%] }\end{array}$ & $\begin{array}{c}\text { Wielkość } \\
\text { strat } \\
{\left[\mathrm{zł} / \mathrm{m}^{2}\right]}\end{array}$ \\
\hline \multirow{12}{*}{ Warty } & Gidle & 3625,09 & 0,10 & 0,04 & 0,01 & 2,54 \\
\hline & Radomsko & 1242,42 & 0,10 & - & - & 2,39 \\
\hline & Ładzice & 189,45 & 0,03 & - & - & 2,29 \\
\hline & Działoszyn & 726,09 & 0,08 & 39,05 & 0,2 & 5,97 \\
\hline & Burzenin & 690,68 & 0,01 & 84,04 & - & 0,47 \\
\hline & Zapolice & 953,63 & - & 5,88 & 0,04 & 0,21 \\
\hline & $\begin{array}{l}\text { Sieradz (gmina } \\
\text { wiejska) }\end{array}$ & 2513,11 & 0,01 & 16,27 & - & 0,38 \\
\hline & Sieradz (miasto) & 740,17 & 0,05 & 0,4 & - & 2,48 \\
\hline & Warta & 1919,37 & - & 100 & 0,02 & 0,7 \\
\hline & Pęczniew & 2278,94 & 0,02 & 83,43 & - & 0,6 \\
\hline & Poddębice & 3671,87 & 0,03 & 13,4 & 0,04 & 1,34 \\
\hline & Uniejów & 729,42 & 0,08 & 100 & - & 2,69 \\
\hline \multirow{7}{*}{ Pilicy } & Żytno & 969,48 & 0,02 & 100 & - & 0,54 \\
\hline & Rozprza & 902,27 & 0,02 & - & - & 2,95 \\
\hline & Sulejów & 1022,29 & 0,02 & 73,82 & - & 0,83 \\
\hline & Czarnocin & 321,67 & 0,01 & - & - & 0,29 \\
\hline & $\begin{array}{l}\text { Tomaszów } \\
\text { Mazowiecki } \\
\text { (gmina wiejska) }\end{array}$ & 1583,8 & 0,04 & 61,22 & 0,03 & 2,72 \\
\hline & $\begin{array}{l}\text { Tomaszów } \\
\text { Mazowiecki } \\
\text { (miasto) }\end{array}$ & 761,59 & 0,23 & 11,33 & 5,49 & 39,54 \\
\hline & Inowłódz & 828,4 & 0,03 & 89,32 & - & 1,20 \\
\hline \multirow{2}{*}{ Bzury } & Kutno & 292,6 & 0,32 & - & 0,44 & 14,65 \\
\hline & Łowicz & 396,24 & 0,34 & 47,86 & 0,82 & 8,23 \\
\hline \multicolumn{2}{|c|}{$\bar{x}$ (śr. arytm.) } & & 0,07 & 39,34 & 0,34 & 4,43 \\
\hline
\end{tabular}

Objaśnienia: (-) zjawisko nie występuje; (.) zjawisko występowało w wielkości mniejszej od 0,01 ha.

Źródło: opracowanie własne, 2013. 
Tabela 5.3. Wielkość obiektów i terenów poszczególnych kategorii ryzyka powodziowego w granicach wody 100-letniej badanych gmin województwa łódzkiego w stosunku do średniej arytmetycznej

\begin{tabular}{|c|c|c|c|c|c|}
\hline Zlewnia & Gminy & $\begin{array}{c}\text { Obiekty } \\
\text { o znaczeniu } \\
\text { społecznym }\end{array}$ & $\begin{array}{c}\text { Obiekty } \\
\text { dziedzictwa } \\
\text { kulturowego } \\
\text { i tereny cenne } \\
\text { przyrodniczo }\end{array}$ & $\begin{array}{c}\text { Obiekty } \\
\text { zagrażające } \\
\text { środowisku } \\
\text { oraz ludziom }\end{array}$ & $\begin{array}{c}\text { Straty } \\
\text { ekonomiczne }\end{array}$ \\
\hline \multirow{12}{*}{ Warty } & Gidle & $\boldsymbol{\Delta}$ & $\nabla$ & $\nabla$ & $\nabla$ \\
\hline & Radomsko & $\Delta$ & - & - & $\nabla$ \\
\hline & Ładzice & $\nabla$ & - & - & $\nabla$ \\
\hline & Działoszyn & $\Delta$ & $\nabla$ & $\nabla$ & $\Delta$ \\
\hline & Burzenin & $\nabla$ & $\Delta$ & - & $\nabla$ \\
\hline & Zapolice & - & $\nabla$ & $\nabla$ & $\nabla$ \\
\hline & $\begin{array}{l}\text { Sieradz (gmina } \\
\text { wiejska) }\end{array}$ & $\nabla$ & $\boldsymbol{\nabla}$ & - & $\nabla$ \\
\hline & Sieradz (miasto) & $\nabla$ & $\nabla$ & - & $\nabla$ \\
\hline & Warta & - & $\Delta$ & $\nabla$ & $\nabla$ \\
\hline & Pęczniew & $\nabla$ & $\Delta$ & 一 & $\nabla$ \\
\hline & Poddębice & $\nabla$ & $\nabla$ & $\nabla$ & $\nabla$ \\
\hline & Uniejów & $\Delta$ & $\Delta$ & - & $\nabla$ \\
\hline \multirow{7}{*}{ Pilicy } & Żytno & $\nabla$ & $\Delta$ & - & $\nabla$ \\
\hline & Rozprza & $\nabla$ & - & - & $\nabla$ \\
\hline & Sulejów & $\nabla$ & $\Delta$ & - & $\nabla$ \\
\hline & Czarnocin & $\nabla$ & - & - & $\nabla$ \\
\hline & $\begin{array}{l}\text { Tomaszów } \\
\text { Mazowiecki } \\
\text { (gmina wiejska) }\end{array}$ & $\nabla$ & $\Delta$ & $\nabla$ & $\nabla$ \\
\hline & $\begin{array}{l}\text { Tomaszów } \\
\text { Mazowiecki } \\
\text { (miasto) }\end{array}$ & $\Delta$ & $\nabla$ & $\Delta$ & $\Delta$ \\
\hline & Inowłódz & $\nabla$ & $\Delta$ & 一 & $\nabla$ \\
\hline \multirow{2}{*}{ Bzury } & Kutno & $\Delta$ & - & $\Delta$ & $\Delta$ \\
\hline & Łowicz & $\Delta$ & $\Delta$ & $\Delta$ & $\Delta$ \\
\hline
\end{tabular}

Objaśnienia: $\boldsymbol{\Delta}$ - powyżej średniej, $\boldsymbol{\nabla}$ - poniżej średniej, „-”- brak średniej arytmetycznej. Kolorem ciemnoszarym oznaczono kategorie ryzyka powodziowego, których udział był wyższy od wartości średniej arytmetycznej, wyliczonej dla określonej kategorii w badanych gminach. Kolor jasnoszary oznacza, iż wartość ta była niższa od wartości średniej arytmetycznej. Kolor biały to brak obiektów i terenów danej kategorii ryzyka powodziowego w gminie.

Źródło: opracowanie własne, 2013. 


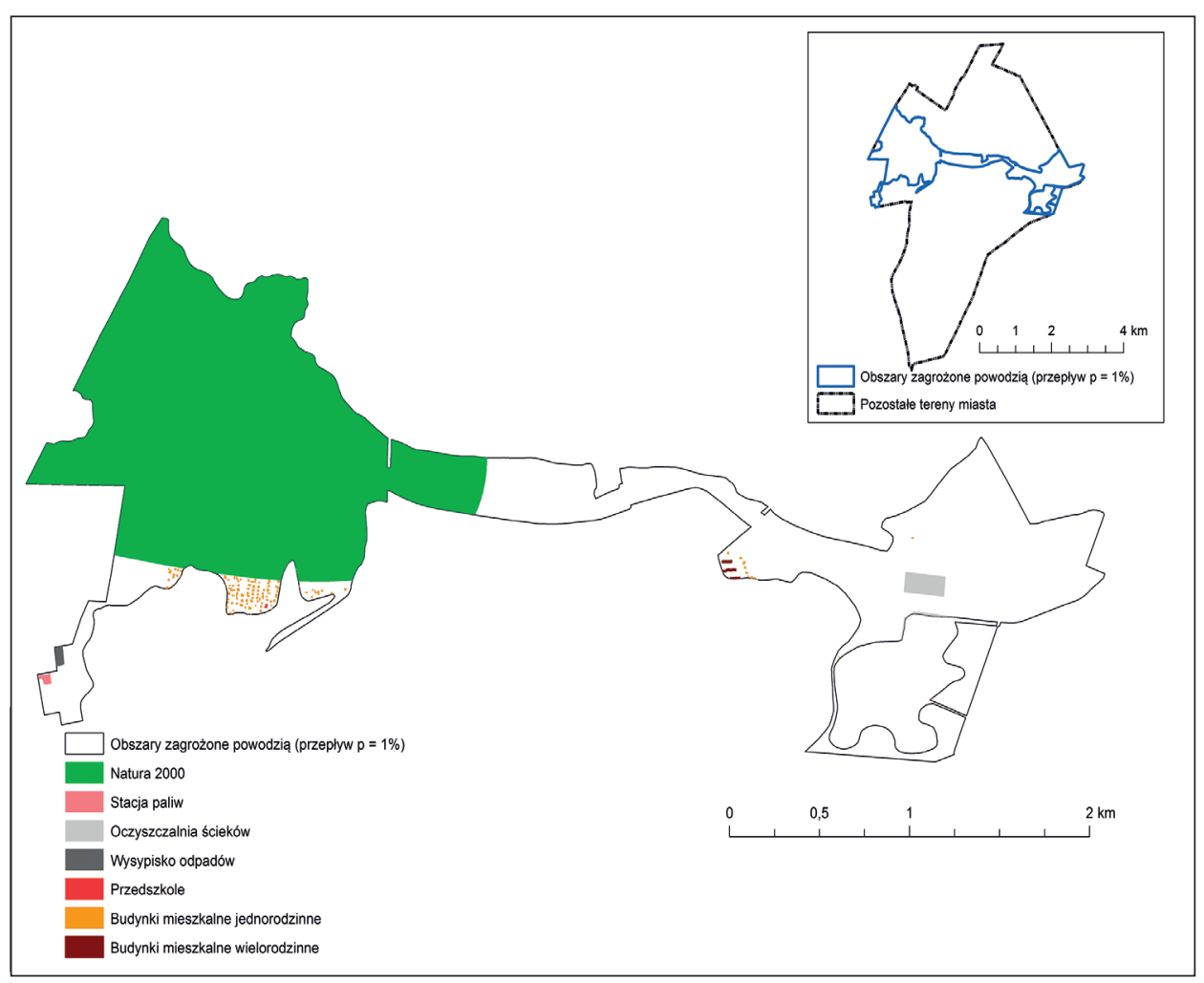

Rycina 5.1. Obiekty i tereny wszystkich kategorii ryzyka powodziowego w granicach wody 100-letniej w Łowiczu

Źródło: opracowanie własne, 2013

W wyniku analizy poszczególnych kategorii ryzyka powodziowego można zauważyć, iż poza terenami cennymi przyrodniczo, pozostałe tereny i obiekty dominują głównie w miastach oraz tam, gdzie dno doliny jest bardzo szerokie.

\section{Kategorie ryzyka powodziowego według powierzchni zajmowanej w danej gminie na obszarze zalewowym}

W celu analizy kategorii ryzyka powodziowego dominujących w badanych gminach wzięto pod uwagę powierzchnię zajmowaną przez poszczególne grupy obiektów i terenów (tabela 5.4). Z analizy wyłączono potencjalną wartość utraty majątku, gdyż ona pojawiła się w przypadku wszystkich gmin, ponadto trudno ją porównać z obiektami powierzchniowymi. 
Tabela 5.4. Klasyfikacja kategorii ryzyka powodziowego na terenach zalewowych według powierzchni zajmowanej w poszczególnych gminach

\begin{tabular}{|c|c|c|c|c|}
\hline Zlewnia & Gminy & $\begin{array}{c}\text { Obiekty } \\
\text { o znaczeniu } \\
\text { społecznym }\end{array}$ & $\begin{array}{c}\text { Obiekty } \\
\text { dziedzictwa } \\
\text { kulturowego } \\
\text { i tereny cenne } \\
\text { przyrodniczo }\end{array}$ & $\begin{array}{c}\text { Obiekty } \\
\text { zagrażające } \\
\text { środowisku } \\
\text { oraz ludziom }\end{array}$ \\
\hline \multirow{12}{*}{ Warty } & Gidle & +++ & ++ & + \\
\hline & Radomsko & +++ & - & - \\
\hline & Ładzice & +++ & - & - \\
\hline & Działoszyn & + & +++ & ++ \\
\hline & Burzenin & ++ & +++ & - \\
\hline & Zapolice & - & +++ & ++ \\
\hline & Sieradz (gmina wiejska) & ++ & +++ & - \\
\hline & Sieradz (miasto) & ++ & +++ & - \\
\hline & Warta & - & +++ & ++ \\
\hline & Pęczniew & ++ & +++ & - \\
\hline & Poddębice & + & +++ & ++ \\
\hline & Uniejów & ++ & +++ & - \\
\hline \multirow{7}{*}{ Pilicy } & Żytno & ++ & +++ & - \\
\hline & Rozprza & +++ & - & - \\
\hline & Sulejów & ++ & +++ & - \\
\hline & Czarnocin & +++ & - & - \\
\hline & $\begin{array}{l}\text { Tomaszów Mazowiecki } \\
\text { (gmina wiejska) }\end{array}$ & ++ & +++ & + \\
\hline & $\begin{array}{l}\text { Tomaszów Mazowiecki } \\
\text { (miasto) }\end{array}$ & + & +++ & ++ \\
\hline & Inowłódz & ++ & +++ & - \\
\hline \multirow{2}{*}{ Bzury } & Kutno & ++ & - & +++ \\
\hline & Łowicz & + & +++ & ++ \\
\hline
\end{tabular}

Objaśnienia: „,++" - największa, „++” - średnia, „+" - najmniejsza, „,” - brak. Kolorem szarym oznaczono tę kategorię ryzyka powodziowego, która dominuje w danej gminie, na terenie zagrożonym powodzią.

Źródło: opracowanie własne, 2013. 
W przypadku 14 gmin na obszarach zagrożonych powodziami dominują tereny cenne przyrodniczo oraz obiekty dziedzictwa kulturowego, na drugim miejscu znalazły się obiekty o znaczeniu społecznym (5 gmin).

Obiekty zagrażające środowisku przyrodniczemu oraz ludziom jako dominujące $\mathrm{w}$ granicach wody $1 \%$ danej gminy pojawiły się tylko w dwóch przypadkach - Kutna (rycina 5.2) oraz Tomaszowa Mazowieckiego (miasta) (rycina 5.3). Sytuacja ta jest bardzo niekorzystna, ponieważ gdy dojdzie do ich zalania, zanieczyszczenia mogą być przenoszone na znaczne odległości.

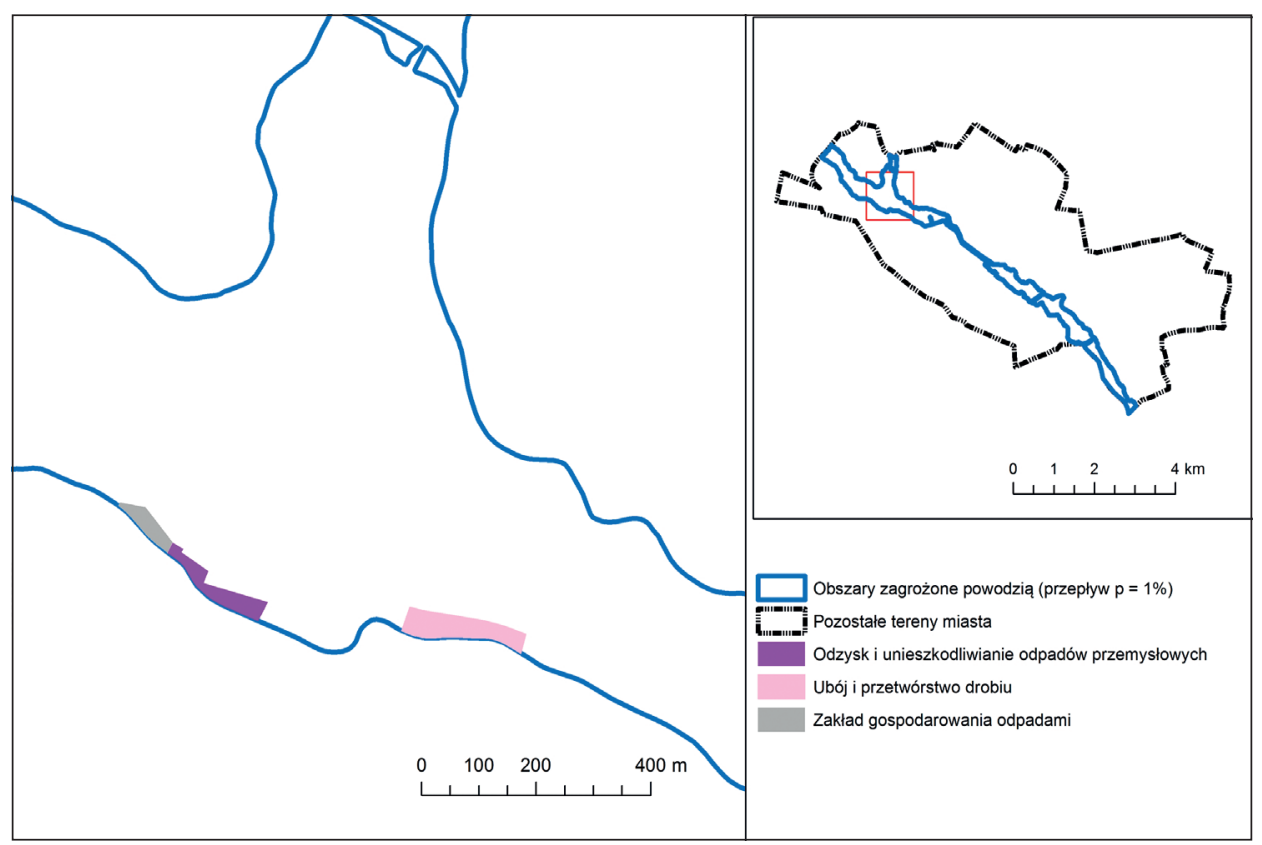

Rycina 5.2. Obiekty potencjalnie zagrażające środowisku przyrodniczemu oraz ludziom w przypadku zalania w Kutnie Źródło: opracowanie własne, 2013

We wszystkich analizowanych gminach znajdują się obiekty oraz tereny, które w przypadku zalania są narażone na negatywne konsekwencje. Dlatego też niezwykle ważnym zagadnieniem jest właściwa ochrona tych obszarów w celu ograniczenia ryzyka powodziowego lub jego eliminacji. 


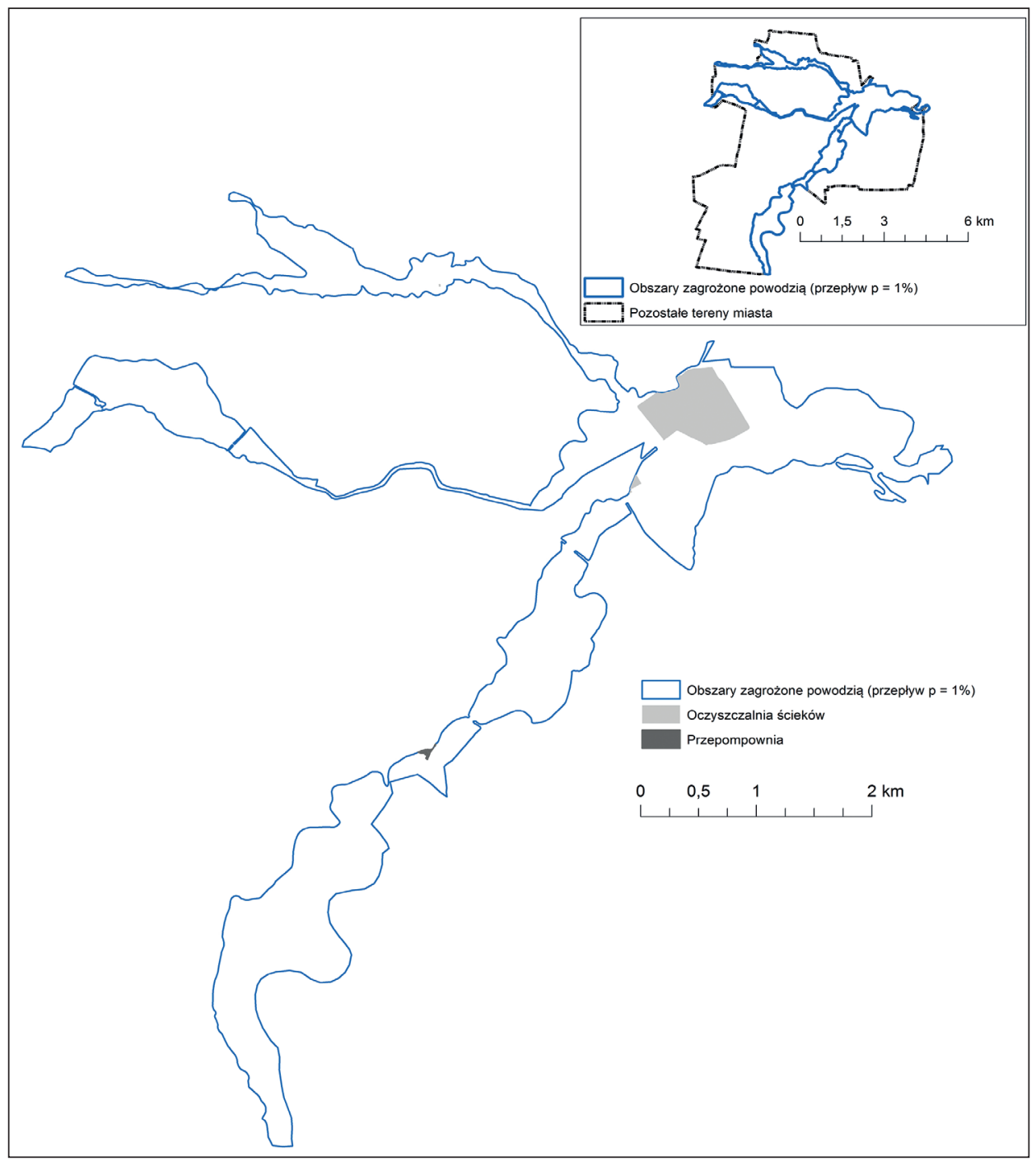

Rycina 5.3. Obiekty potencjalnie zagrażające środowisku przyrodniczemu oraz ludziom w przypadku zalania w Tomaszowie Mazowieckim Źródło: opracowanie własne, 2013

\subsection{Poziom ryzyka powodziowego}

Z uwagi na szkody, jakie wywołują powodzie w ostatnim czasie, niezbędne staje się wiarygodne szacowanie potencjalnych negatywnych konsekwencji na obszarach zagrożonych zalaniem. Szczególne znaczenie ma to dla terenów zurbanizowanych, intensywnie zainwestowanych oraz gęsto zaludnionych. Szacowanie 
potencjalnych szkód powinno być wykorzystywane do właściwej ochrony przed powodzią. Jednak jest to zadanie niezwykle trudne, w szczególności, że dotyczy tak różnych kategorii, jak zagrożenie środowiska przyrodniczego, ludzi, dziedzictwa kulturowego, działalności gospodarczej. Niestety wciąż nie opracowano niezawodnej metodyki obliczania szkód (Chojnacki 2000).

W pracy przeanalizowano udział heksagonów o określonym stopniu ryzyka powodziowego, w granicach wody $1 \%$, w każdej wyodrębnionej kategorii (tabela 5.5). W wyniku tych obliczeń uzyskano wartości dla wszystkich gmin w danej kategorii ryzyka, następnie uszeregowano je malejąco zgodnie z uzyskanymi wielkościami i na tej podstawie stworzono ranking gmin według poziomu tego ryzyka.

W grupie obiektów, gdzie czasowo lub na stałe mogą przebywać ludzie (tabela 5.6) największe ryzyko występuje w Kutnie (rycina 5.4), Radomsku (rycina 5.5) oraz Tomaszowie Mazowieckim (mieście). Obiekty te są rozproszone na obszarze zalewowym i stanowią je przede wszystkim budynki mieszkalne jednorodzinne. Jak już zostało wspomniane, ludzie chętniej inwestują na obszarach mniejszych zlewni, w miastach oraz tam, gdzie równiny zalewowe są szerokie.

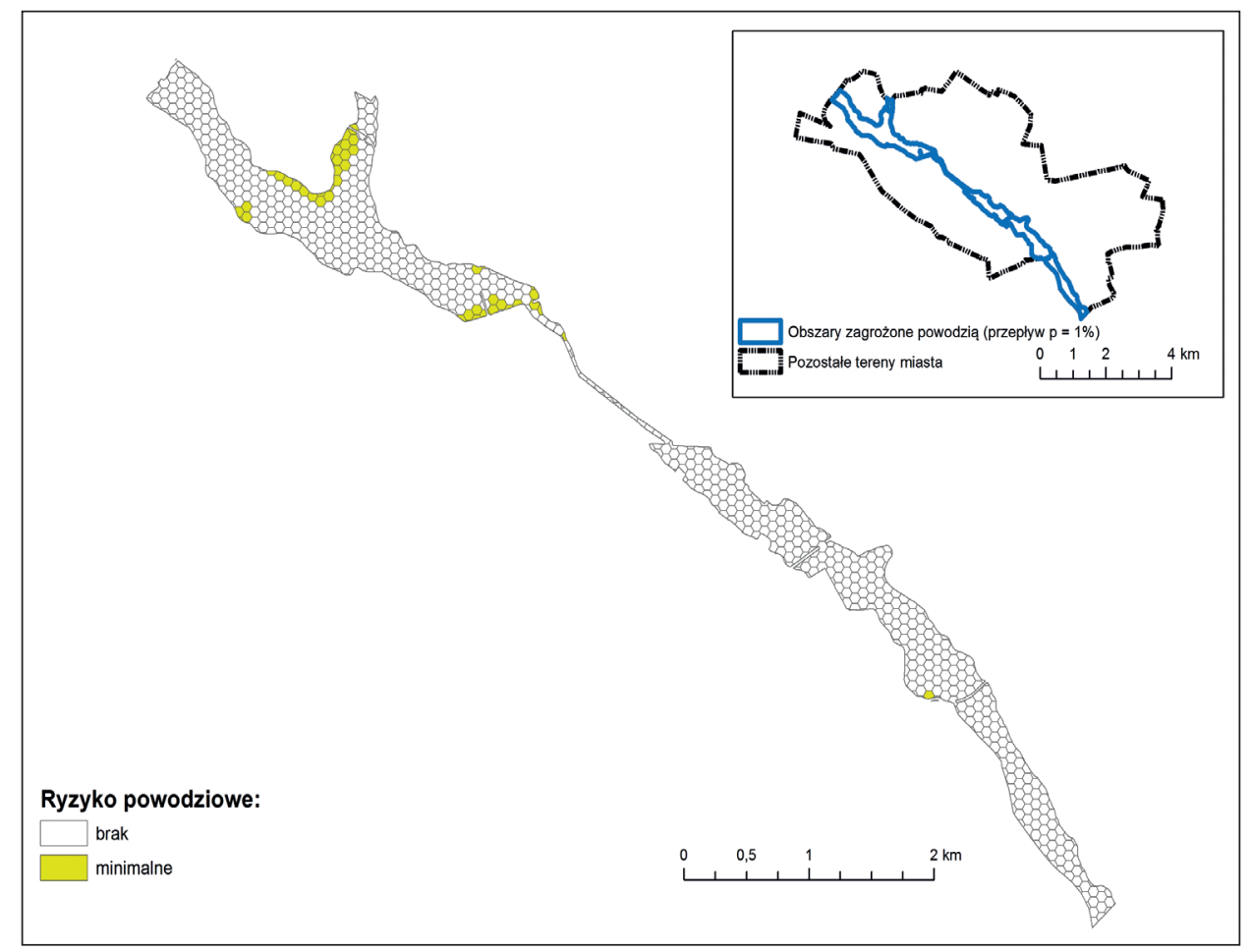

Rycina 5.4. Ryzyko powodziowe - obiekty o znaczeniu społecznym w Kutnie Źródło: opracowanie własne, 2013 


\begin{tabular}{|c|c|c|c|c|c|c|c|c|c|c|c|c|c|}
\hline \multirow{5}{*}{ 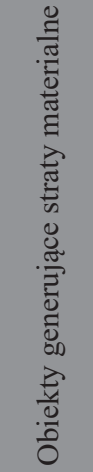 } & in & $\hat{O}_{0}^{0}$ & 1 & 1 & $\begin{array}{l}0 \\
+ \\
0\end{array}$ & 1 & 1 & 1 & 1 & 1 & 1 & $\begin{array}{l}\overline{0} \\
0\end{array}$ & $\frac{n}{0}$ \\
\hline & $\nabla$ & o. & $\begin{array}{l}\text { J } \\
0\end{array}$ & 1 & $\begin{array}{c}\text { ले } \\
\text { ô }\end{array}$ & I & 1 & 1 & $\begin{array}{l}\text { กิ } \\
\text { ô }\end{array}$ & I & $\begin{array}{l}\text { Oै } \\
0\end{array}$ & $\begin{array}{l}\text { I } \\
0\end{array}$ & $\frac{n}{0}$ \\
\hline & $m$ & $\frac{1}{0}$ & $\begin{array}{l}8 \\
0 \\
0\end{array}$ & $\begin{array}{l}\infty \\
0 \\
0\end{array}$ & $\hat{\hat{0}}$ & 1 & 1 & 1 & $\hat{0}$ & 1 & $\begin{array}{l}n \\
0 \\
0\end{array}$ & $\begin{array}{l}J \\
0\end{array}$ & $\overline{\sigma_{0}}$ \\
\hline & $N$ & مू & $\begin{array}{l}\text { ్ } \\
\text { N̦ }\end{array}$ & 1 & $\hat{\sigma}$ & $\begin{array}{l}\infty \\
0 \\
0\end{array}$ & $\begin{array}{l}\circ \\
0 \\
0\end{array}$ & $\begin{array}{l}\text { to } \\
0 \\
0\end{array}$ & $\begin{array}{l}\hat{n} \\
0\end{array}$ & $\begin{array}{l}n \\
0 \\
0\end{array}$ & $\begin{array}{l}\text { ô } \\
0\end{array}$ & $\frac{2}{0}$ & $\begin{array}{l}\infty \\
m \\
0 \\
0\end{array}$ \\
\hline & - & $\begin{array}{l}m \\
m \\
\infty\end{array}$ & $\begin{array}{l}\bar{\sigma} \\
\text { aे }\end{array}$ & $\begin{array}{l}n \\
\tilde{n}\end{array}$ & $\begin{array}{l}\stackrel{n}{f} \\
\hat{a}\end{array}$ & $\begin{array}{l}\alpha \\
\alpha\end{array}$ & $\begin{array}{l}\text { मे } \\
\text { aे }\end{array}$ & $\begin{array}{l}\circ \\
\text { ूे }\end{array}$ & $\frac{1}{a}$ & $\begin{array}{l}\text { ñ } \\
\text { nn }\end{array}$ & $\begin{array}{l}\circ \\
\text { ని }\end{array}$ & $\begin{array}{l}\infty \\
n \\
2\end{array}$ & 2 \\
\hline \multirow{5}{*}{ 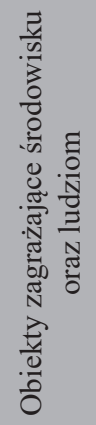 } & $n$ & 1 & 1 & 1 & $\begin{array}{l}\infty \\
0 \\
0\end{array}$ & 1 & 1 & 1 & I & 1 & I & $\begin{array}{l}0 \\
0\end{array}$ & 1 \\
\hline & $\nabla$ & 1 & I & 1 & 1 & 1 & 1 & 1 & 1 & 1 & 1 & $\begin{array}{l}0 \\
0\end{array}$ & 1 \\
\hline & $m$ & 1 & I & 1 & $\frac{n}{0}$ & 1 & 1 & 1 & 1 & 1 & 1 & $\begin{array}{l}0 \\
0 \\
0\end{array}$ & 1 \\
\hline & $N$ & $\begin{array}{l}\text { I } \\
0\end{array}$ & 1 & 1 & $\frac{n}{0}$ & 1 & $\begin{array}{l}\circ \\
\circ \\
0\end{array}$ & 1 & 1 & $\begin{array}{l}\overline{0} \\
0\end{array}$ & 1 & 1 & 1 \\
\hline & - & I & I & 1 & $\begin{array}{l}\bar{m} \\
0\end{array}$ & 1 & 1 & 1 & 1 & $\begin{array}{l}8 \\
0\end{array}$ & 1 & $\begin{array}{l}\text { I } \\
0\end{array}$ & 1 \\
\hline \multirow{5}{*}{ 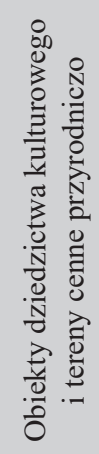 } & in & $\tilde{O}_{0}$ & I & 1 & $\frac{a}{n}$ & $\infty$ & $\begin{array}{l}\text { \& } \\
\text { in }\end{array}$ & $\begin{array}{l}0 \\
\stackrel{\sim}{\simeq}\end{array}$ & तે & 8 & $\hat{\sigma}$ & $\begin{array}{l}8 \\
m\end{array}$ & 8 \\
\hline & $\nabla$ & $\overline{0}_{0}$ & 1 & 1 & ले & 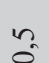 & సิ & $\exists$ & $\frac{n}{0}$ & 1 & $\approx$ & $\hat{0}$ & 1 \\
\hline & $m$ & $\begin{array}{l}\delta_{0} \\
0\end{array}$ & I & 1 & $\begin{array}{l}\infty \\
0 \\
0 \\
0\end{array}$ & $\tilde{o}$ & $\dot{\sigma}_{0}^{+}$ & $\begin{array}{l}\infty \\
\tilde{\sigma}\end{array}$ & 1 & 1 & $\begin{array}{l}\infty \\
0 \\
0\end{array}$ & $\frac{m}{0}$ & 1 \\
\hline & $N$ & I & 1 & 1 & $\begin{array}{l}\infty \\
0 \\
0\end{array}$ & $\begin{array}{l}\tilde{2} \\
\text { on }\end{array}$ & $\begin{array}{l}n \\
\text { ñ } \\
0\end{array}$ & $\tilde{0}$ & 1 & 1 & $\hat{0}$ & $\begin{array}{l}0 \\
0 \\
0\end{array}$ & I \\
\hline & - & \&. & 1 & 1 & $\frac{n}{0}$ & $\frac{n}{0}$ & $\hat{\sigma}$ & $\begin{array}{l}0 \\
\infty \\
0\end{array}$ & $\begin{array}{l}\text { ते } \\
0\end{array}$ & 1 & $\begin{array}{l}0 \\
\text { n. } \\
0\end{array}$ & $\hat{0}$ & 1 \\
\hline \multirow{5}{*}{ 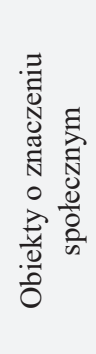 } & in & 1 & 1 & 1 & 1 & 1 & 1 & 1 & 1 & 1 & 1 & 1 & 1 \\
\hline & $\nabla$ & 1 & I & 1 & 1 & 1 & 1 & 1 & 1 & 1 & I & I & I \\
\hline & $m$ & 1 & 1 & 1 & 1 & 1 & 1 & 1 & 1 & 1 & 1 & 1 & $\begin{array}{l}\infty \\
0 \\
0\end{array}$ \\
\hline & N & 1 & $\begin{array}{l}\text { to } \\
0\end{array}$ & 1 & 1 & 1 & 1 & 1 & 1 & I & 1 & 1 & 1 \\
\hline & - & $\begin{array}{l}\text { n. } \\
\text { m. }\end{array}$ & $\begin{array}{l}\triangleright \\
\triangleright \\
+\end{array}$ & $\vec{\sigma}$ & 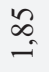 & $\begin{array}{l}\text { in } \\
\text { on }\end{array}$ & 1 & $\begin{array}{l}\circ \\
8 \\
0\end{array}$ & $\stackrel{\circ}{\stackrel{\circ}{\sim}}$ & I & $\frac{m}{0}$ & $\underset{\sigma}{\sigma}$ & - \\
\hline \multicolumn{2}{|c|}{ 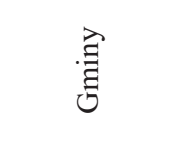 } & $\frac{0}{\overrightarrow{0}}$ & 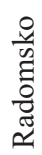 & 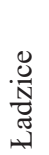 & 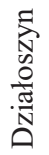 & 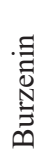 & 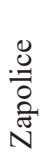 & 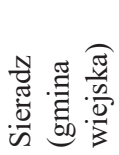 & 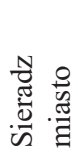 & $\stackrel{\frac{\pi}{7}}{3}$ & 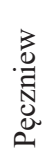 & $\begin{array}{l}\frac{8}{0} \\
\frac{0}{8} \\
\frac{0}{0} \\
0\end{array}$ & 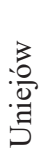 \\
\hline \multicolumn{2}{|c|}{ 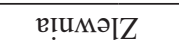 } & & & & & & & Кұ., & & & & & \\
\hline
\end{tabular}




\begin{tabular}{|c|c|c|c|c|c|c|c|c|}
\hline 1 & $\vec{n}$ & $\begin{array}{l}8 \\
0 \\
0\end{array}$ & । & $\begin{array}{l}\vec{\pi} \\
0\end{array}$ & $\stackrel{\infty}{\sim}$ & । & $\begin{array}{l}\bar{\sigma} \\
0\end{array}$ & $\stackrel{m}{\sigma}_{0}$ \\
\hline । & $\stackrel{n}{\tilde{c}}$ & । & । & 1 & $\stackrel{\sigma}{\sigma}$ & । & $\underset{\mathrm{\sigma}}{\mathrm{O}}$ & $\stackrel{\nabla}{0}$ \\
\hline 1 & $\begin{array}{l}8 \\
0\end{array}$ & $\stackrel{\sim}{\circ}$ & । & $\stackrel{\infty}{\stackrel{\infty}{0}}$ & $\begin{array}{l}n \\
0 \\
\text { in }\end{array}$ & । & ปี & $\begin{array}{l}\infty \\
0 \\
0\end{array}$ \\
\hline$\stackrel{ }{0}$ & $\frac{1}{0}$ & $\frac{\infty}{0}$ & । & $\begin{array}{l}\hat{b} \\
0\end{array}$ & $\begin{array}{l}\mathscr{n} \\
\infty \\
+\end{array}$ & $\stackrel{m}{2}$ & $\stackrel{n}{n}$ & no \\
\hline $\begin{array}{l}\text { ma } \\
\text { â }\end{array}$ & ล̊ & $\stackrel{m}{\dot{\infty}}$ & $\frac{m}{0}$ & $\begin{array}{l}\text { ले } \\
\text { fै }\end{array}$ & $\begin{array}{l}\vec{\sigma} \\
\infty\end{array}$ & $\stackrel{\infty}{\circ}$ & $\begin{array}{l}\text { oे } \\
\dot{a}\end{array}$ & 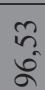 \\
\hline I & I & । & 1 & 1 & 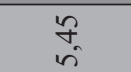 & । & । & $\stackrel{m}{f}$ \\
\hline । & I & । & 1 & I & $\hat{O}^{2}$ & 1 & । & I \\
\hline । & I & । & । & 1 & $\begin{array}{l}n \\
\tilde{0}\end{array}$ & 1 & గn & $\begin{array}{l}\infty \\
n \\
n\end{array}$ \\
\hline । & । & । & 1 & $\begin{array}{l}\text { J } \\
0\end{array}$ & $\bar{\sigma}$ & । & $\bar{\sigma}_{0}$ & $\stackrel{\nabla}{\circ}$ \\
\hline । & । & 1 & । & $\stackrel{ \pm}{0}$ & $\begin{array}{l}\infty \\
0 \\
0\end{array}$ & $\hat{0}$ & $\begin{array}{l}\overline{0} \\
0\end{array}$ & in \\
\hline$\stackrel{8}{\circ}$ & I & $\begin{array}{l}\vec{m} \\
\stackrel{+}{\sim}\end{array}$ & । & $\begin{array}{l}\bar{m} \\
\hat{\sigma}\end{array}$ & $\begin{array}{l}0 \\
\infty\end{array}$ & $\begin{array}{l}\circ \\
\dot{0} \\
\infty\end{array}$ & I & $\begin{array}{l}0 \\
\text { nn } \\
\text { nn }\end{array}$ \\
\hline । & । & $\begin{array}{l}n \\
\tilde{0}\end{array}$ & । & $\begin{array}{l}n \\
\hat{0}\end{array}$ & $\begin{array}{l}\infty \\
0 \\
0\end{array}$ & $\dot{\sigma}_{0}$ & । & $\frac{2}{0}$ \\
\hline I & । & $\stackrel{\tilde{\sigma}}{\sigma}$ & । & $\frac{\infty}{0}$ & $\begin{array}{l}\hat{b} \\
0\end{array}$ & $\hat{\tilde{o}}$ & I & $\stackrel{0}{\Rightarrow}$ \\
\hline 1 & । & $\underset{\widetilde{\Omega}}{\tilde{0}}$ & । & $\begin{array}{l}1 \\
0 \\
0\end{array}$ & $\underset{\sigma}{\exists}$ & $\hat{\tilde{o}}$ & I & $\begin{array}{l}\infty \\
n \\
0\end{array}$ \\
\hline 1 & । & $\hat{n}$ & । & 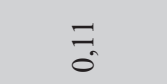 & $\stackrel{ }{\hat{0}}$ & $\begin{array}{l}\text { +o } \\
\text { o. }\end{array}$ & । & $\frac{N}{0}$ \\
\hline । & । & । & । & I & । & I & । & । \\
\hline । & । & । & 1 & I & । & 1 & । & । \\
\hline I & । & । & । & । & I & I & I & । \\
\hline I & । & I & । & । & I & । & । & ते \\
\hline$\frac{n}{2}$ & $\begin{array}{l}\infty \\
0 \\
0\end{array}$ & $\begin{array}{l}n \\
\tilde{0}\end{array}$ & $\frac{\infty}{0}$ & $\cong$ & $\begin{array}{l}n \\
i n \\
\forall\end{array}$ & $\hat{\sigma}$ & $n$ & $\stackrel{\infty}{m}$ \\
\hline 态 & 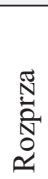 & 高 & 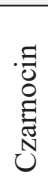 & 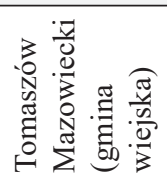 & 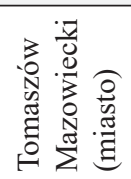 & $\frac{\frac{N}{0}}{\frac{0}{3}}$ & 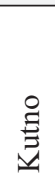 & لَّ \\
\hline \multicolumn{7}{|c|}{ Кэ!!!d } & \multicolumn{2}{|c|}{ K.nnzg } \\
\hline
\end{tabular}




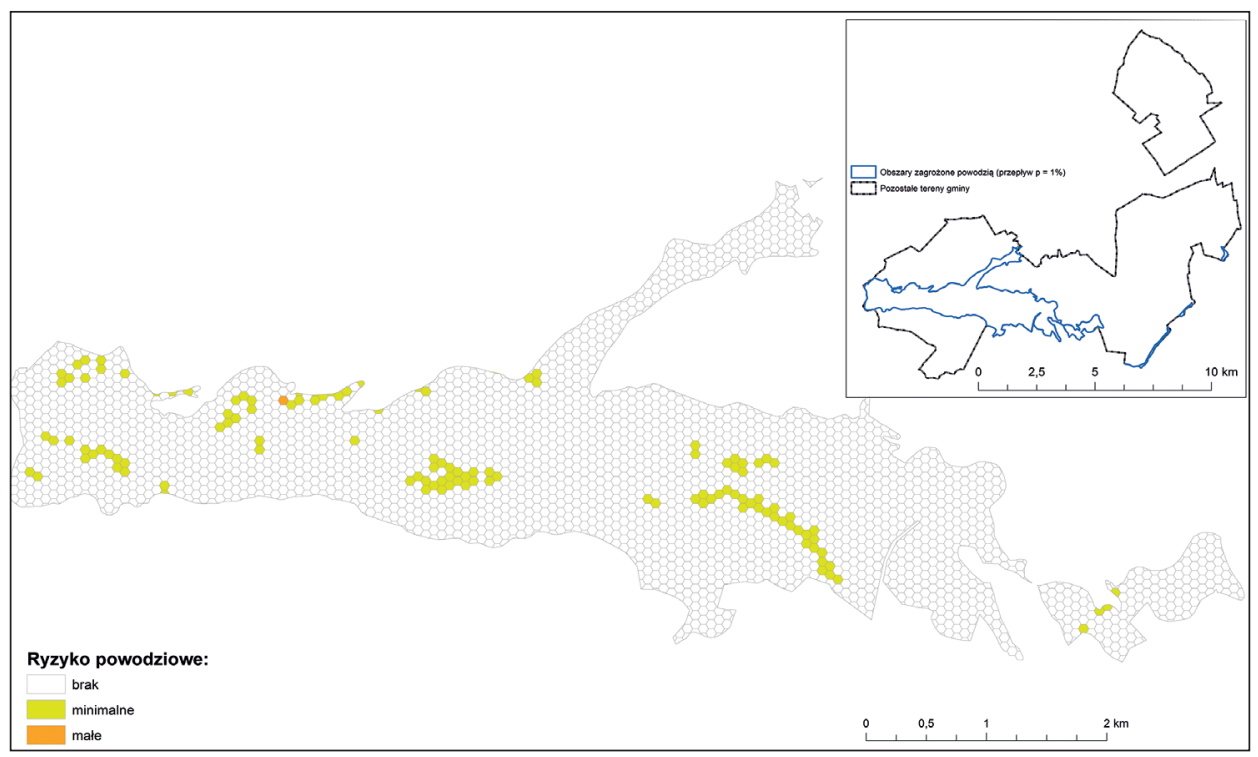

Rycina 5.5. Ryzyko powodziowe - obiekty o znaczeniu społecznym w Radomsku Źródło: opracowanie własne, 2013

Tabela 5.6. Hierarchia gmin według poziomu ryzyka powodziowego w grupie obiektów o znaczeniu społecznym

\begin{tabular}{|c|l|c|}
\hline Lp. & \multicolumn{1}{|c|}{ Gmina } & $\begin{array}{c}\text { Poziom ryzyka powodziowego } \\
\text { W grupie obiektów spolecznych }\end{array}$ \\
\hline 1. & Kutno & 1,06 \\
\hline 2. & Radomsko & 0,98 \\
\hline 3. & Tomaszów Mazowiecki (miasto) & 0,91 \\
\hline 4. & Lowicz & 0,75 \\
\hline 5. & Gidle & 0,71 \\
\hline 6. & Działoszyn & 0,37 \\
\hline 7. & Poddębice & 0,32 \\
\hline 8. & Sieradz (miasto) & 0,29 \\
\hline 9. & Uniejów & 0,25 \\
\hline 10. & Tomaszów Mazowiecki (gmina wiejska) & 0,23 \\
\hline 11. & Ladzice & 0,20 \\
\hline 12. & Inowłódz & 0,19 \\
\hline 13. & Żytno & 0,15 \\
\hline 13. & Pęczniew & 0,15 \\
\hline 15. & Rozprza & 0,14 \\
\hline 16. & Sulejów & 0,11 \\
\hline 17. & Burzenin & 0,05 \\
\hline 18. & Czarnocin & 0,04 \\
\hline & &
\end{tabular}




\begin{tabular}{|c|l|c|}
\hline Lp. & \multicolumn{1}{|c|}{ Gmina } & $\begin{array}{c}\text { Poziom ryzyka powodziowego } \\
\text { w grupie obiektów społecznych }\end{array}$ \\
\hline 19. & Sieradz (gmina wiejska) & 0,01 \\
\hline 20. & Warta & - \\
\hline 20. & Zapolice & - \\
\hline
\end{tabular}

Objaśnienia: (-) zjawisko nie występuje.

Źródło: opracowanie własne, 2013.

Obiekty stwarzające potencjalne zagrożenie dla środowiska przyrodniczego oraz ludzi w przypadku zalania generują największe ryzyko w Tomaszowie Mazowieckim (mieście) (rycina 5.6), Łowiczu (rycina 5.7) oraz Kutnie (tabela 5.7).

Tabela 5.7. Hierarchia gmin według ryzyka powodziowego w grupie obiektów zagrażających środowisku przyrodniczemu oraz ludziom

\begin{tabular}{|c|l|c|}
\hline Lp. & \multicolumn{1}{|c|}{ Gmina } & $\begin{array}{c}\text { Poziom ryzyka powodziowego w grupie } \\
\text { obiektów zagrażających środowisku } \\
\text { przyrodniczemu oraz ludziom }\end{array}$ \\
\hline 1. & Tomaszów Mazowiecki (miasto) & 6,52 \\
\hline 2. & Łowicz & 1,16 \\
\hline 3. & Kutno & 0,41 \\
\hline 4. & Działoszyn & 0,29 \\
\hline 5. & Poddębice & 0,05 \\
\hline 6. & Tomaszów Mazowiecki (gmina wiejska) & 0,04 \\
\hline 7. & Zapolice & 0,02 \\
\hline 7. & Gidle & 0,02 \\
\hline 7. & Warta & 0,02 \\
\hline 10. & Inowłódz & 0,01 \\
\hline 11. & Burzenin & - \\
\hline 11. & Czarnocin & - \\
\hline 11. & Ladzice & - \\
\hline 11. & Pęczniew & - \\
\hline 11. & Radomsko & - \\
\hline 11. & Rozprza & - \\
\hline 11. & Sieradz (miasto) & - \\
\hline 11. & Sieradz (gmina wiejska) & - \\
\hline 11. & Sulejów & - \\
\hline 11. & Uniejów & - \\
\hline 11. & Żytno & \\
\hline & & - \\
\hline
\end{tabular}

Objaśnienia: (-) zjawisko nie występuje.

Źródło: opracowanie własne, 2013. 
W Tomaszowie Mazowieckim wpływ na to ma oczyszczalnia ścieków, która została zlokalizowana w miejscu, gdzie równina zalewowa jest najszersza (obszar gdzie do Pilicy uchodzą mniejsze rzeki). W przypadku Łowicza ryzyko powodziowe generowane jest również przez oczyszczalnię ścieków (znajdującą się we wschodniej części terenu wody 100-letniej) oraz stację paliw (znajdującą się w części południowo-zachodniej zalewu). Obiekty te powinny być zlokalizowane poza obszarem szczególnego zagrożenia powodzią lub posiadać indywidualne zabezpieczenia.

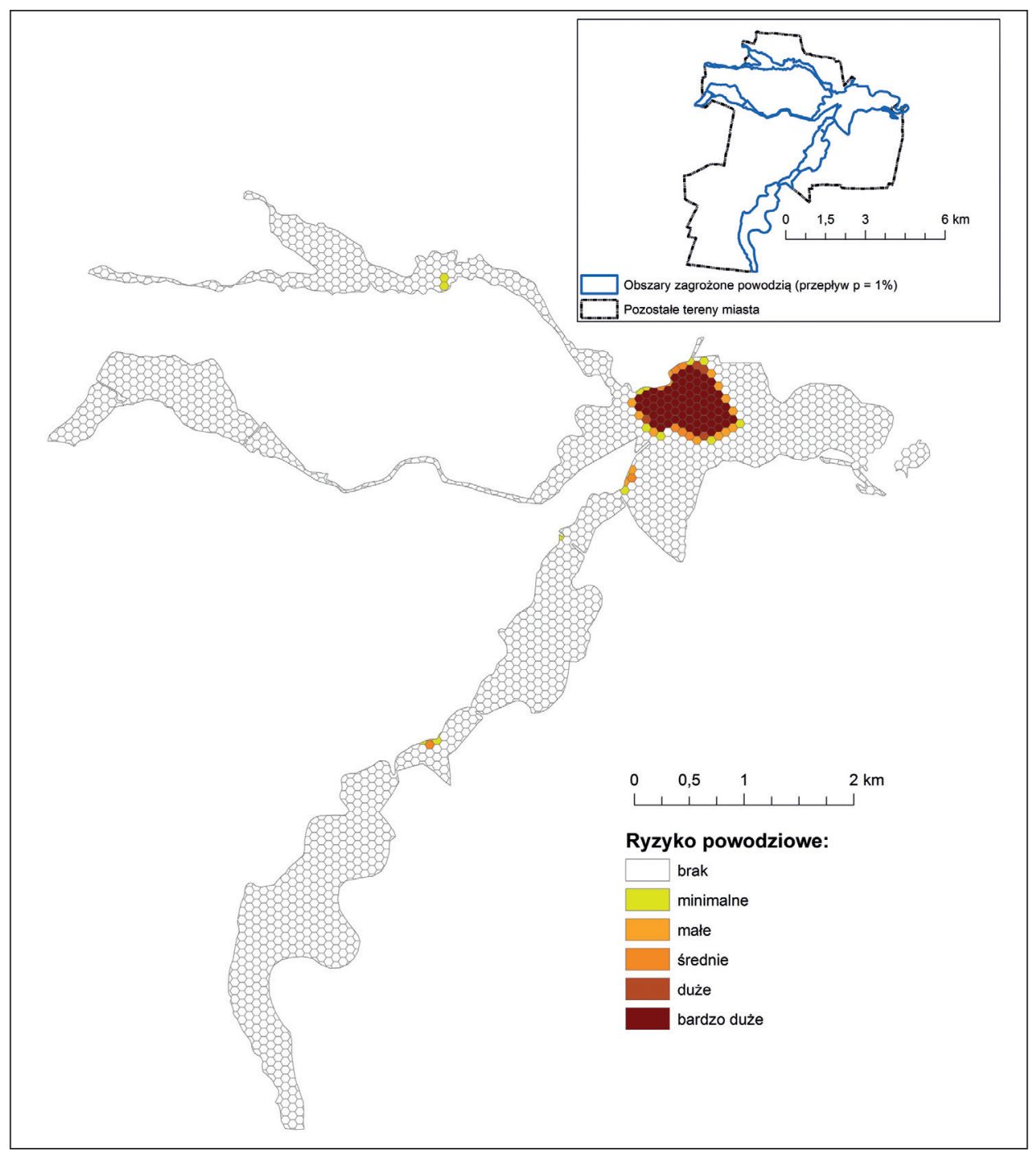

Rycina 5.6. Ryzyko powodziowe - obiekty stwarzające potencjalne zagrożenie dla środowiska przyrodniczego oraz ludzi w przypadku zalania Tomaszowa Mazowieckiego (miasta) Źródło: opracowanie własne, 2013 


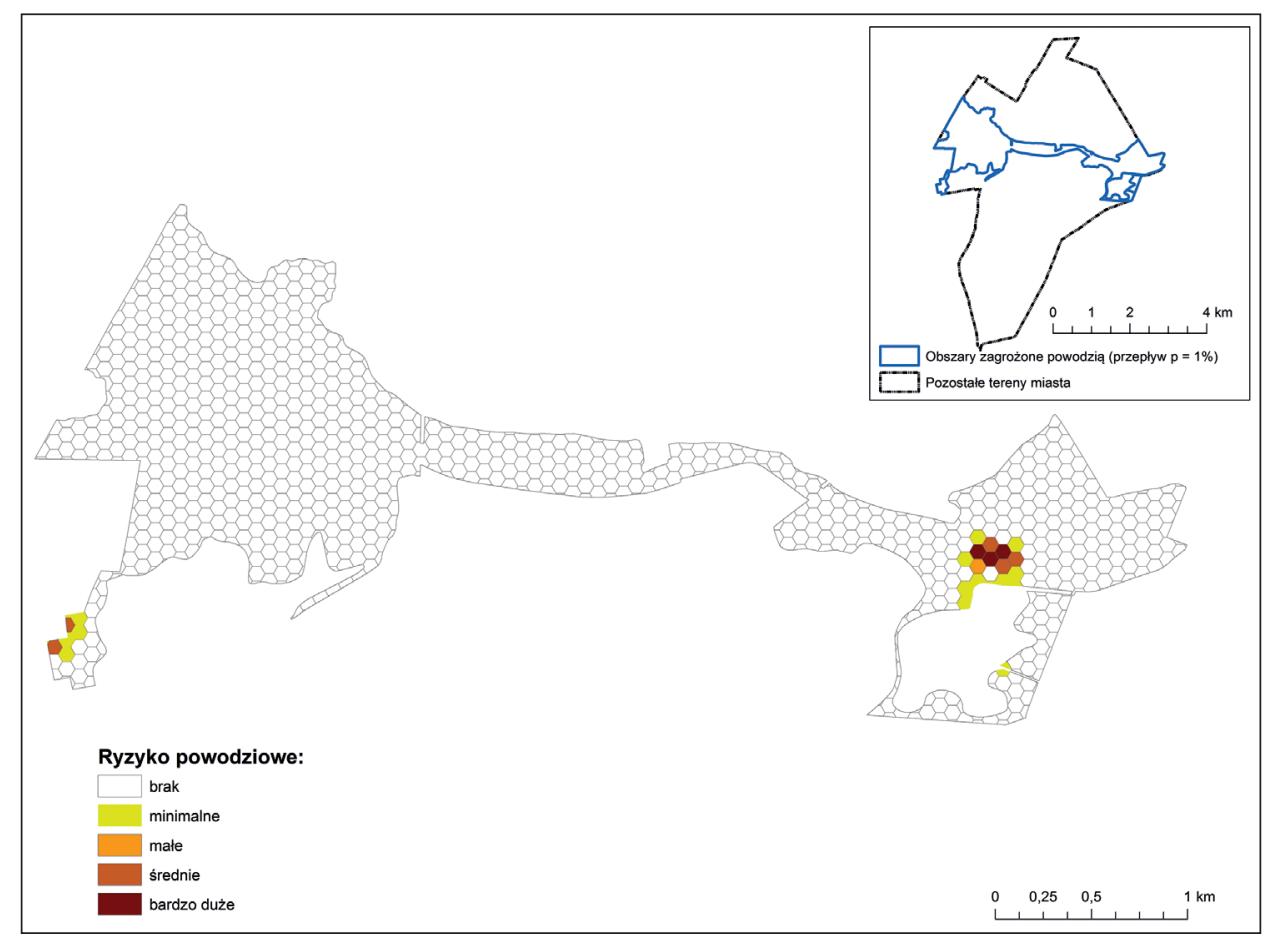

Rycina 5.7. Ryzyko powodziowe - obiekty stwarzające potencjalne zagrożenie dla środowiska przyrodniczego oraz ludzi w przypadku zalania Łowicza Źródło: opracowanie własne, 2013

W wyniku analizy poziomu ryzyka powodziowego dokonanej na podstawie potencjalnych strat majątku, na pierwszym miejscu znalazł się Tomaszów Mazowiecki (miasto) (rycina 5.8), na kolejnych Kutno (rycina 5.9), Łowicz (rycina 5.10) oraz Działoszyn (tabela 5.8). Wynika to głównie ze stopnia poziomej intensywności zagospodarowania. W Tomaszowie Mazowieckim największe potencjalne straty mogą wystąpić w przypadku zalania terenu położonego nad rzekami: Czarna oraz Piasecznica. Generują je firmy zajmujące się produkcją tkanin, dywanów (zlokalizowane nad Wolborką), płytek ceramicznych (zlokalizowane nad rzeką Czarną i Piasecznicą) oraz oczyszczalnia ścieków. W Kutnie obiekty generujące największe straty materialne są rozproszone, znajdują się na obrzeżach terenu szczególnego zagrożenia powodzią, należą do nich przedsiębiorstwa m.in. robót budowlanych oraz zabudowa mieszkaniowa. W Łowiczu największe potencjalne straty materialne generuje oczyszczalnia ścieków, stacja paliw oraz zabudowa mieszkaniowa zarówno jedno-, jak i wielorodzinna.

Bardzo mocno zaznacza się presja urbanistyczna na obszarach miejskich, która pociąga za sobą wzrost zapotrzebowania na „wolne tereny” i wprowadza zmiany w sposobie użytkowania terenów (Mierzejewska 2010). 


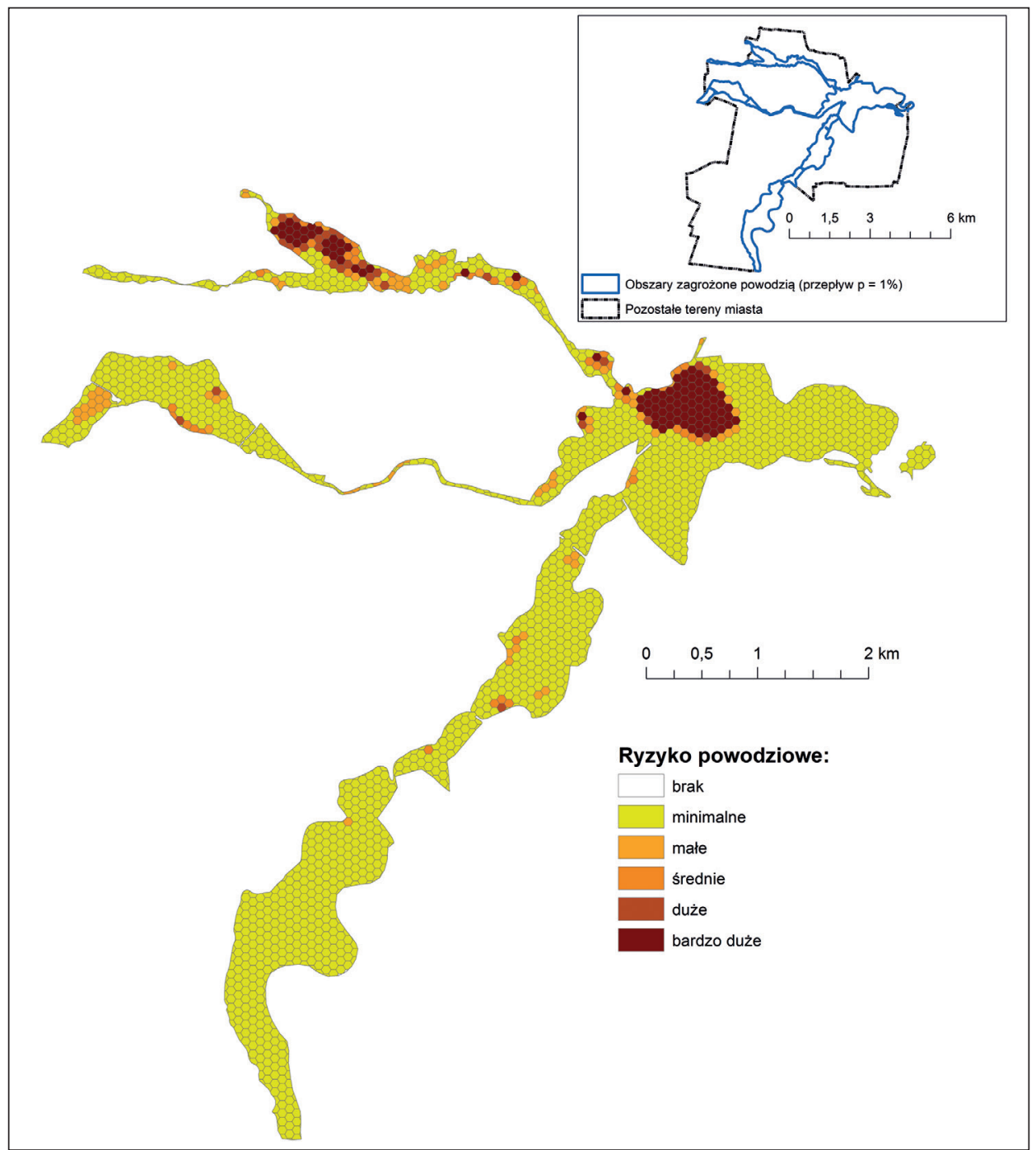

Rycina 5.8. Ryzyko powodziowe - potencjalna utrata majątku w Tomaszowie Mazowieckim Źródło: opracowanie własne, 2013

Tabela 5.8. Hierarchia gmin według ryzyka powodziowego ze względu na potencjalne straty materialne

\begin{tabular}{|c|l|c|}
\hline Lp. & \multicolumn{1}{|c|}{ Gmina } & $\begin{array}{c}\text { Poziom ryzyka powodziowego ze względu } \\
\text { na straty ekonomiczne }\end{array}$ \\
\hline 1. & Tomaszów Mazowiecki (miasto) & 29,03 \\
\hline 2. & Kutno & 22,20 \\
\hline 3. & Łowicz & 21,19 \\
\hline 4. & Działoszyn & 21,10 \\
\hline 5. & Uniejów & 20,42 \\
\hline
\end{tabular}




\begin{tabular}{|c|l|c|}
\hline Lp. & \multicolumn{1}{|c|}{ Gmina } & $\begin{array}{c}\text { Poziom ryzyka powodziowego ze względu } \\
\text { na straty ekonomiczne }\end{array}$ \\
\hline 6. & Sieradz (miasto) & 20,28 \\
\hline 7. & Gidle & 20,21 \\
\hline 8. & Radomsko & 20,11 \\
\hline 9. & Poddębice & 20,07 \\
\hline 10. & Burzenin & 20,02 \\
\hline 11. & Inowłódz & 20,01 \\
\hline 11. & Zapolice & 20,01 \\
\hline 11. & Sieradz (gmina wiejska) & 20,01 \\
\hline 14. & Rozprza & 19,95 \\
\hline 15. & Ładzice & 19,59 \\
\hline 16. & Czarnocin & 19,23 \\
\hline 17. & Żytno & 18,93 \\
\hline 18. & Sulejów & 17,06 \\
\hline 19. & Tomaszów Mazowiecki (gmina wiejska) & 9,43 \\
\hline 20. & Warta & 9,12 \\
\hline 21. & Pęczniew & 3,65 \\
\hline
\end{tabular}

Źródło: opracowanie własne, 2013.

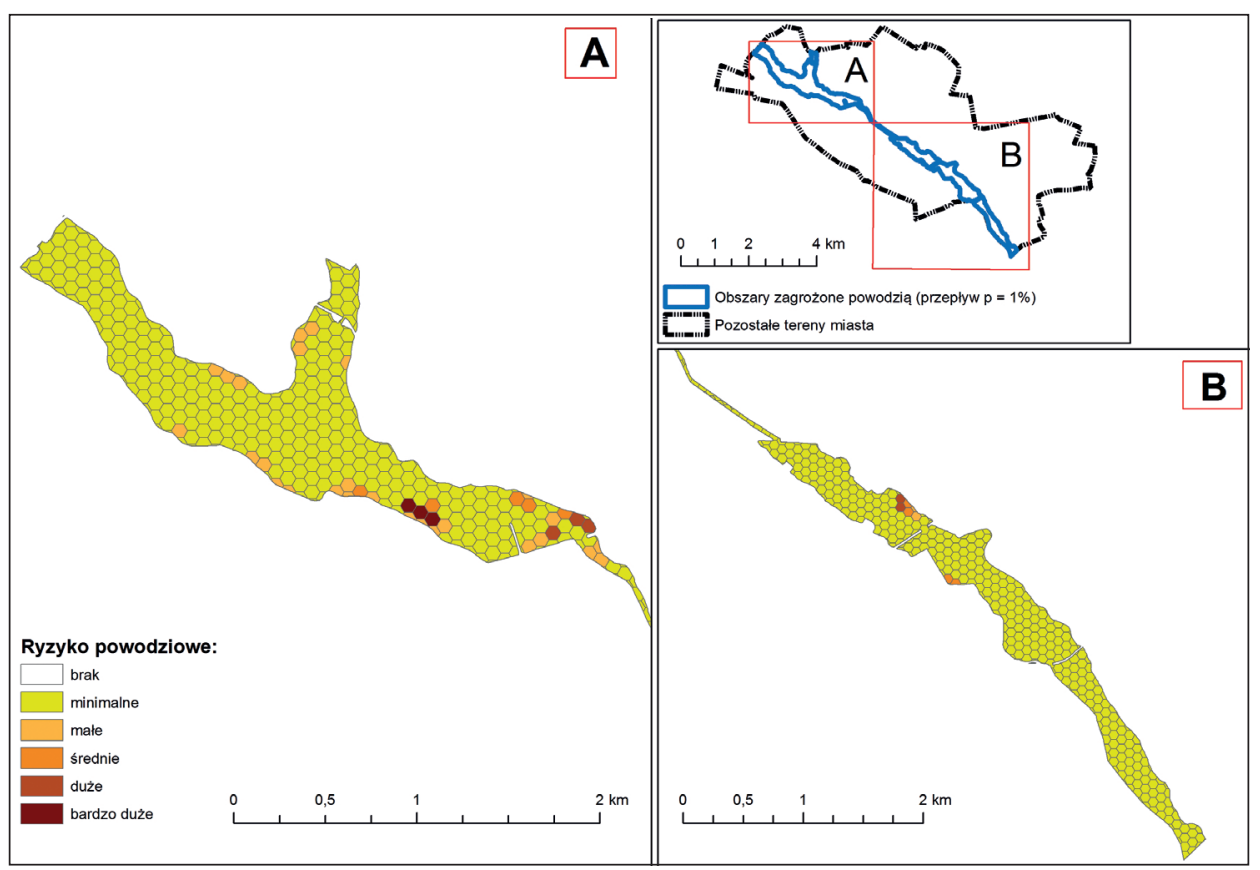

Rycina 5.9. Ryzyko powodziowe - potencjalna utrata majątku w Kutnie Źródło: opracowanie własne, 2013 


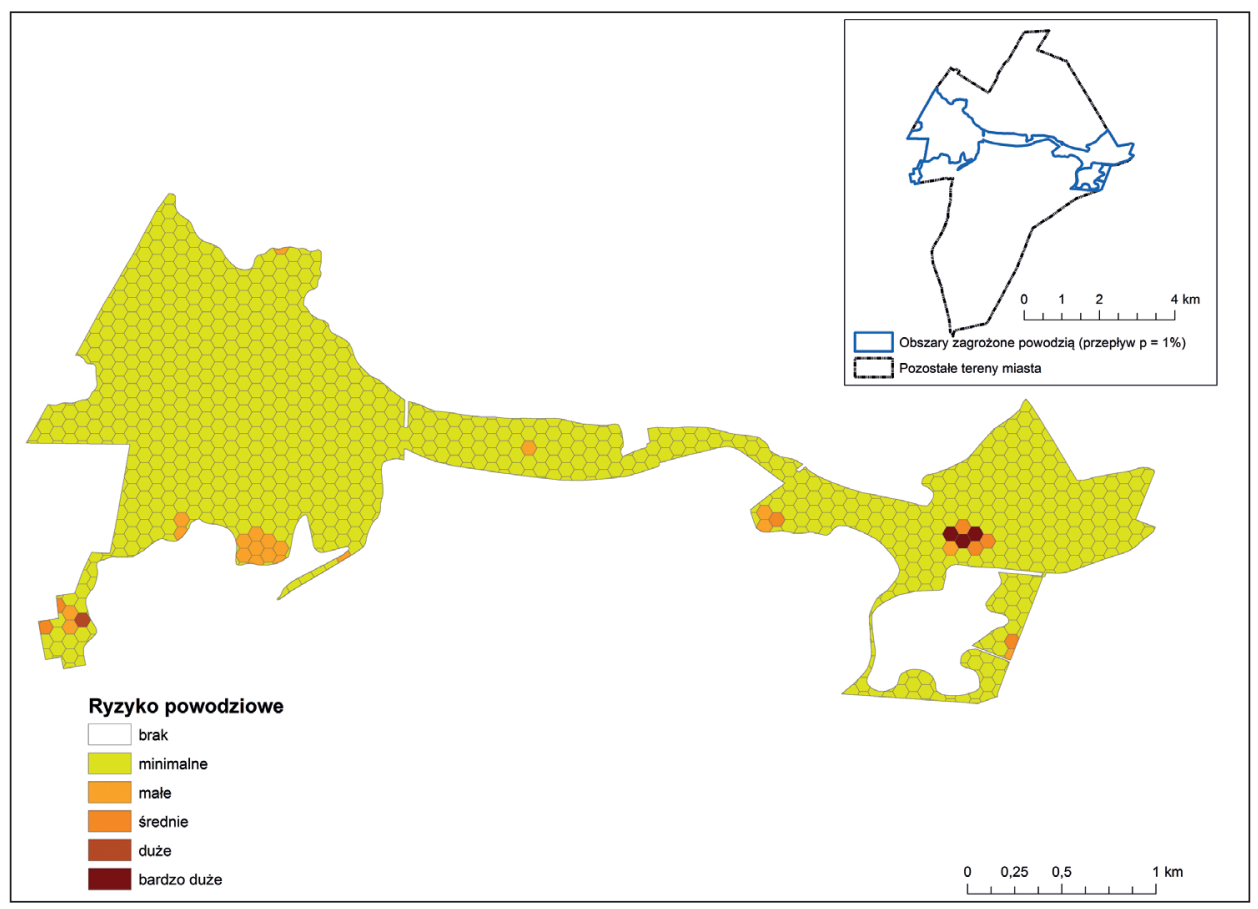

Rycina 5.10. Ryzyko powodziowe - potencjalna utrata majątku w Łowiczu Źródło: opracowanie własne, 2013.

W grupie terenów cennych przyrodniczo oraz obiektów dziedzictwa kulturowego, najwyższy poziom ryzyka (tabela 5.9) jest w gminach: Uniejów, Warta (rycina 5.11), Żytno, gdzie tereny zalewowe to obszary Natura 2000.

Tabela 5.9. Hierarchia gmin według ryzyka powodziowego w grupie obiektów dziedzictwa kulturowego i terenów cennych przyrodniczo

\begin{tabular}{|c|l|c|}
\hline Lp. & \multicolumn{1}{|c|}{ Gmina } & $\begin{array}{c}\text { Poziom ryzyka powodziowego w grupie } \\
\text { obiektów dziedzictwa kulturowego } \\
\text { i terenów cennych przyrodniczo }\end{array}$ \\
\hline 1. & Uniejów & 100,00 \\
\hline 1. & Warta & 100,00 \\
\hline 1. & Żytno & 100,00 \\
\hline 4. & Inowłódz & 90,34 \\
\hline 5. & Burzenin & 85,95 \\
\hline 6. & Pęczniew & 81,99 \\
\hline 7. & Sulejów & 75,21 \\
\hline 8. & Tomaszów Mazowiecki (gmina wiejska) & 63,89 \\
\hline 9. & Lowicz & 52,01 \\
\hline 10. & Działoszyn & 37,61 \\
\hline
\end{tabular}




\begin{tabular}{|c|l|c|}
\hline Lp. & \multicolumn{1}{|c|}{ Gmina } & $\begin{array}{c}\text { Poziom ryzyka powodziowego w grupie } \\
\text { obiektów dziedzictwa kulturowego } \\
\text { i terenów cennych przyrodniczo }\end{array}$ \\
\hline 11. & Sieradz (gmina wiejska) & 14,53 \\
\hline 12. & Poddębice & 13,23 \\
\hline 13. & Tomaszów Mazowiecki (miasto) & 9,99 \\
\hline 14. & Zapolice & 6,08 \\
\hline 15. & Sieradz (miasto) & 0,47 \\
\hline 16. & Gidle & 0,06 \\
\hline 17. & Czarnocin & 0,00 \\
\hline 17. & Kutno & 0,00 \\
\hline 17. & Ladzice & 0,00 \\
\hline 17. & Radomsko & 0,00 \\
\hline 17. & Rozprza & 0,00 \\
\hline
\end{tabular}

Objaśnienia: (-) zjawisko nie występuje.

Źródło: opracowanie własne, 2013.

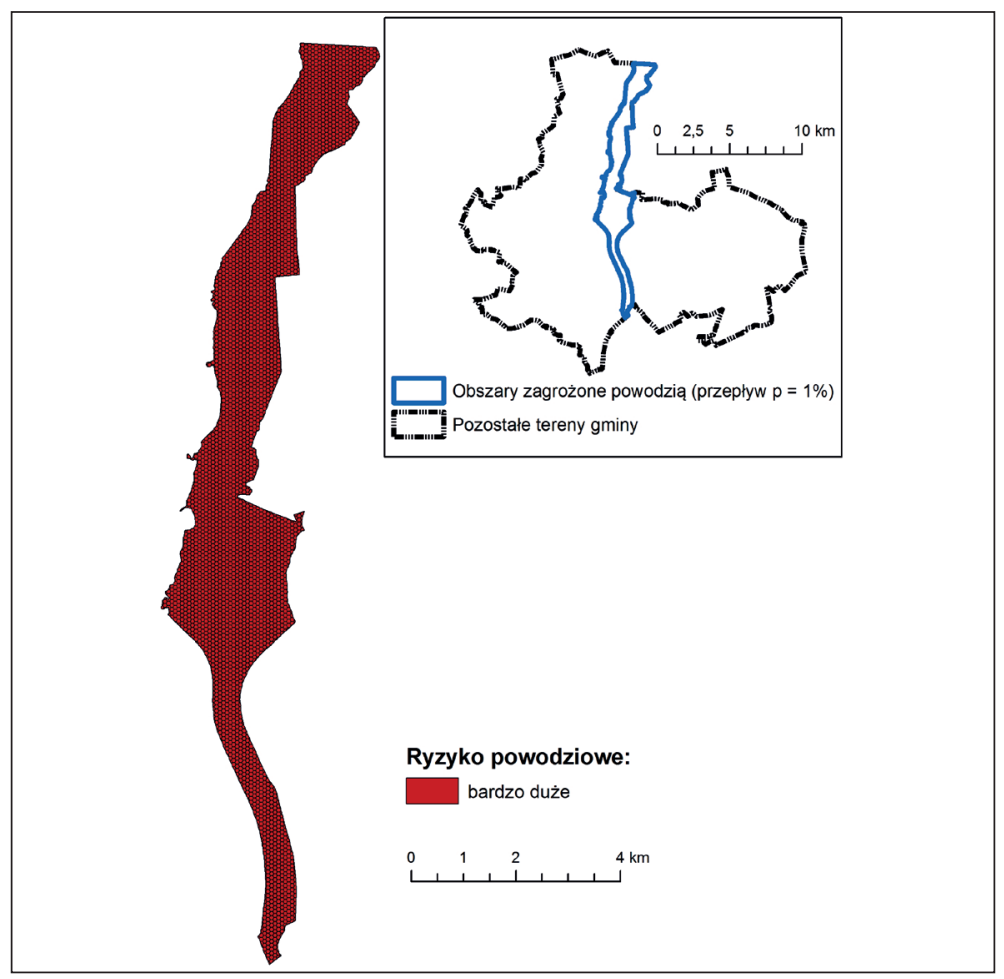

Rycina 5.11. Ryzyko powodziowe - potencjalne negatywne konsekwencje dla środowiska przyrodniczego i dziedzictwa kulturowego w Warcie Źródło: opracowanie własne, 2013 
$\mathrm{Na}$ terenach cennych przyrodniczo dochodzi do zabudowy budownictwem kubaturowym, liniowym oraz zmiany użytkowania gruntów. Zjawisko to jest bardzo niekorzystne z przyrodniczego punktu widzenia, jednak wciąż brak jest akceptacji społecznej dla ochrony obszarów o wysokich walorach przyrodniczych (Borowska-Stefańska 2013). W związku z tym istnieje potencjalne zagrożenie, że w przypadku powodzi tereny cenne przyrodniczo utracą swoje wartości, dlatego też uwzględnia się je w ocenie ryzyka powodziowego (przy założenia najgorszego scenariusza, gdyż oddziaływanie wezbrań na te tereny jest zdecydowanie korzystne). W Uniejowie zabudowa terenu szczególnego zagrożenia powodzią, a tym samym obszaru Natura 2000, generuje potencjalne straty materialne oraz stwarza zagrożenie dla środowiska przyrodniczego. Tereny cenne przyrodniczo występują znacznie częściej na obszarach gmin wiejskich oraz miejsko-wiejskich.

$\mathrm{Na}$ koniec dokonano oceny syntetycznego poziomu ryzyka powodziowego w badanych gminach województwa łódzkiego. W pierwszej kolejności przeanalizowano poziom ryzyka w każdym heksagonie, we wszystkich jego kategoriach, ze względu na powierzchnię przez nie zajmowaną. Autorka przyjęła zasadę, iż jeśli występuje zagrożenie i zalane zostaną obiekty, które pokrywają cały teren zalewowy, ale należą do jednej kategorii ryzyka powodziowego, np. obiektów zagrażających środowisku przyrodniczemu oraz ludziom, to ma to znaczący wpływ na cały teren ${ }^{1}$. Analizując $w$ ten sposób poziom ryzyka (rycina 5.12), najwyższy jest w Uniejowie (rycina 5.13), Warcie oraz Żytnie (tabele 5.10-5.11).

Tabela 5.10. Udział heksagonów o określonym poziomie ryzyka w całkowitej powierzchni terenów zagrożonych powodzią w badanych gminach województwa łódzkiego

\begin{tabular}{|l|l|c|c|c|c|c|}
\hline \multirow{2}{*}{ Zlewnia } & \multicolumn{6}{|c|}{ Poziomy ryzyka } \\
\cline { 3 - 7 } & & 1 & 2 & 3 & 4 & 5 \\
\hline \multirow{5}{*}{ Warty } & Gidle & 98,33 & 0,92 & 0,12 & 0,09 & 0,03 \\
\cline { 2 - 7 } & Radomsko & 99,61 & 0,26 & 0,09 & 0,04 & - \\
\cline { 2 - 7 } & Ladzice & 95,95 & - & 0,68 & - & - \\
\cline { 2 - 7 } & Działoszyn & 59,8 & 0,93 & 0,23 & 0,77 & 37,65 \\
\cline { 2 - 7 } & Burzenin & 13,78 & 0,25 & 0,5 & 0,5 & 85 \\
\cline { 2 - 7 } & Zapolice & 93,67 & 0,58 & 0,4 & 0,29 & 5,06 \\
\cline { 2 - 7 } & Sieradz (gmina wiejska) & 84,36 & 0,75 & 0,98 & 1,11 & 12,6 \\
\cline { 2 - 7 } & Sieradz miasto & 98,83 & 0,59 & 0,07 & 0,22 & 0,29 \\
\cline { 2 - 7 } & Warta & - & - & - & - & 100 \\
\cline { 2 - 7 } & Pęczniew & 16,74 & 0,72 & 0,91 & 1,75 & 79,7 \\
\cline { 2 - 7 } & Poddębice & 86,28 & 0,25 & 0,17 & 0,07 & 13,1 \\
\cline { 2 - 7 } & Uniejów & - & - & - & - & 100 \\
\hline
\end{tabular}

1 W tym przypadku zastosowano wzór, który służył do ustalenia hierarchii gmin według poziomu ryzyka powodziowego w każdej wyodrębnionej kategorii. Poziom katastrofalny nie wystąpił w ogóle, dlatego we wzorze zastosowano 5 klas. 


\begin{tabular}{|l|l|c|c|c|c|c|}
\hline \multirow{3}{*}{ Zlewnia } & \multicolumn{5}{|c|}{ Gminy } & \multicolumn{5}{c|}{ Poziomy ryzyka } \\
\cline { 3 - 7 } & Żytno & 1 & 2 & 3 & 4 & 5 \\
\cline { 2 - 7 } & Rozprza & - & - & - & - & 100 \\
\cline { 2 - 7 } & Sulejów & 96,77 & 0,12 & 0,06 & 0,25 & 0,31 \\
\cline { 2 - 7 } Pilicy & Czarnocin & 94,34 & 0,35 & 0,47 & 0,53 & 74,31 \\
\cline { 2 - 7 } & $\begin{array}{l}\text { Tomaszów Mazowiecki } \\
\text { (gmina wiejska) }\end{array}$ & 34,96 & 0,49 & 0,32 & 0,53 & 63,52 \\
\cline { 2 - 7 } & $\begin{array}{l}\text { Tomaszów Mazowiecki } \\
\text { (miasto) }\end{array}$ & 74,32 & 5,24 & 2,67 & 2,45 & 15,31 \\
\cline { 2 - 7 } & Inowłódz & 9,28 & 0,4 & 0,27 & 0,4 & 89,66 \\
\hline \multirow{2}{*}{ Bzury } & Kutno & 94,09 & 3,05 & 1,22 & 1,02 & 0,61 \\
\cline { 2 - 7 } & Lowicz & 43,7 & 2,6 & 2,03 & 0,87 & 50,8 \\
\hline
\end{tabular}

Objaśnienia: (-) zjawisko nie występuje.

Źródło: opracowanie własne, 2013.

Tabela 5.11. Hierarchia gmin według syntetycznego poziomu ryzyka powodziowego (ze względu na powierzchnię zajmowaną przez obszary i obiekty różnych kategorii)

\begin{tabular}{|c|l|l|}
\hline Lp. & \multicolumn{1}{|c|}{ Gmina } & \multicolumn{1}{|c|}{ Ryzyko ogółem } \\
\hline 1. & Uniejów & 100,00 \\
\hline 1. & Warta & 100,00 \\
\hline 1. & Żytno & 100,00 \\
\hline 4. & Inowłódz & 92,15 \\
\hline 5. & Burzenin & 88,56 \\
\hline 6. & Pęczniew & 85,28 \\
\hline 7. & Sulejów & 80,02 \\
\hline 8. & Tomaszów Mazowiecki (gmina wiejska) & 71,33 \\
\hline 9. & Lowicz & 62,49 \\
\hline 10. & Działoszyn & 50,74 \\
\hline 11. & Tomaszów Mazowiecki (miasto) & 35,83 \\
\hline 12. & Sieradz (gmina wiejska) & 31,25 \\
\hline 13. & Poddębice & 30,62 \\
\hline 14. & Zapolice & 24,50 \\
\hline 15. & Kutno & 22,20 \\
\hline 16. & Sieradz (miasto) & 20,51 \\
\hline 17. & Gidle & 20,21 \\
\hline 18. & Radomsko & 20,11 \\
\hline 19. & Rozprza & 19,95 \\
\hline 20. & Ladzice & 19,59 \\
\hline 21. & Czarnocin & 19,23 \\
\hline & & \\
\hline
\end{tabular}

Objaśnienia: hierarchii gmin dokonano, przyjmując 5 przedziałów klasowych: 0-20 (minimalny poziom ryzyka); 20,01-40 (mały); 40,01-60 (średni); 60,01-80 (duży); 80,01-100 (bardzo duży).

Źródło: opracowanie własne, 2013. 


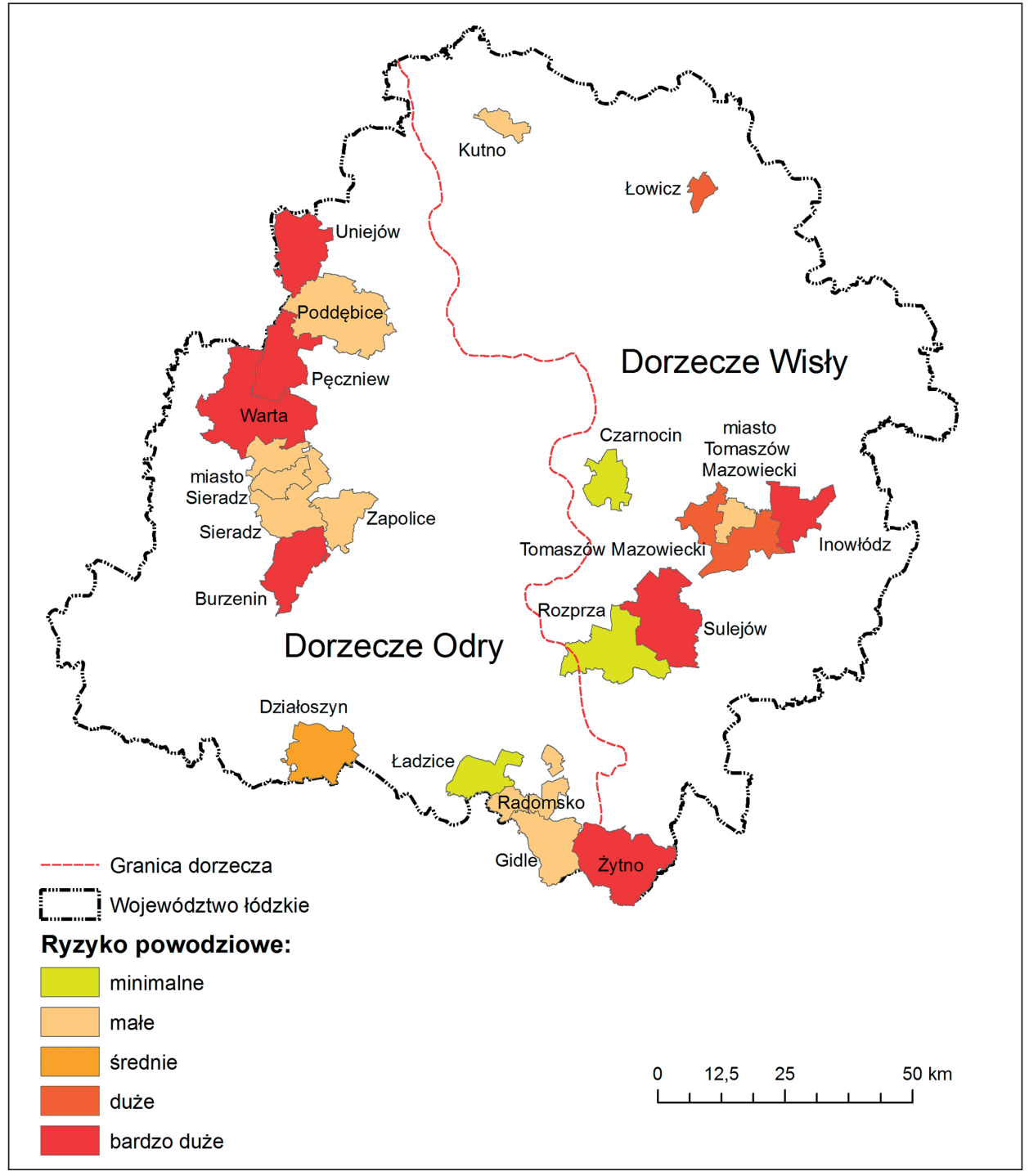

Rycina 5.12. Syntetyczny poziom ryzyka powodziowego w badanych gminach województwa łódzkiego według powierzchni zajmowanej przez obiekty i tereny wyodrębnionych kategorii na terenach zagrożonych powodziami Źródło: opracowanie własne, 2013

W wyniku analizy syntetycznego poziomu ryzyka powodziowego, według powierzchni zajmowanej przez obiekty i tereny przypisane do poszczególnych kategorii ryzyka powodziowego, na pierwszym miejscu znalazły się gminy, w których granicach zalewu dominują tereny cenne przyrodniczo. Klasyfikacja ta w ocenie autorki nie w pełni odzwierciedla faktyczny poziom ryzyka powodziowego. Dlatego 


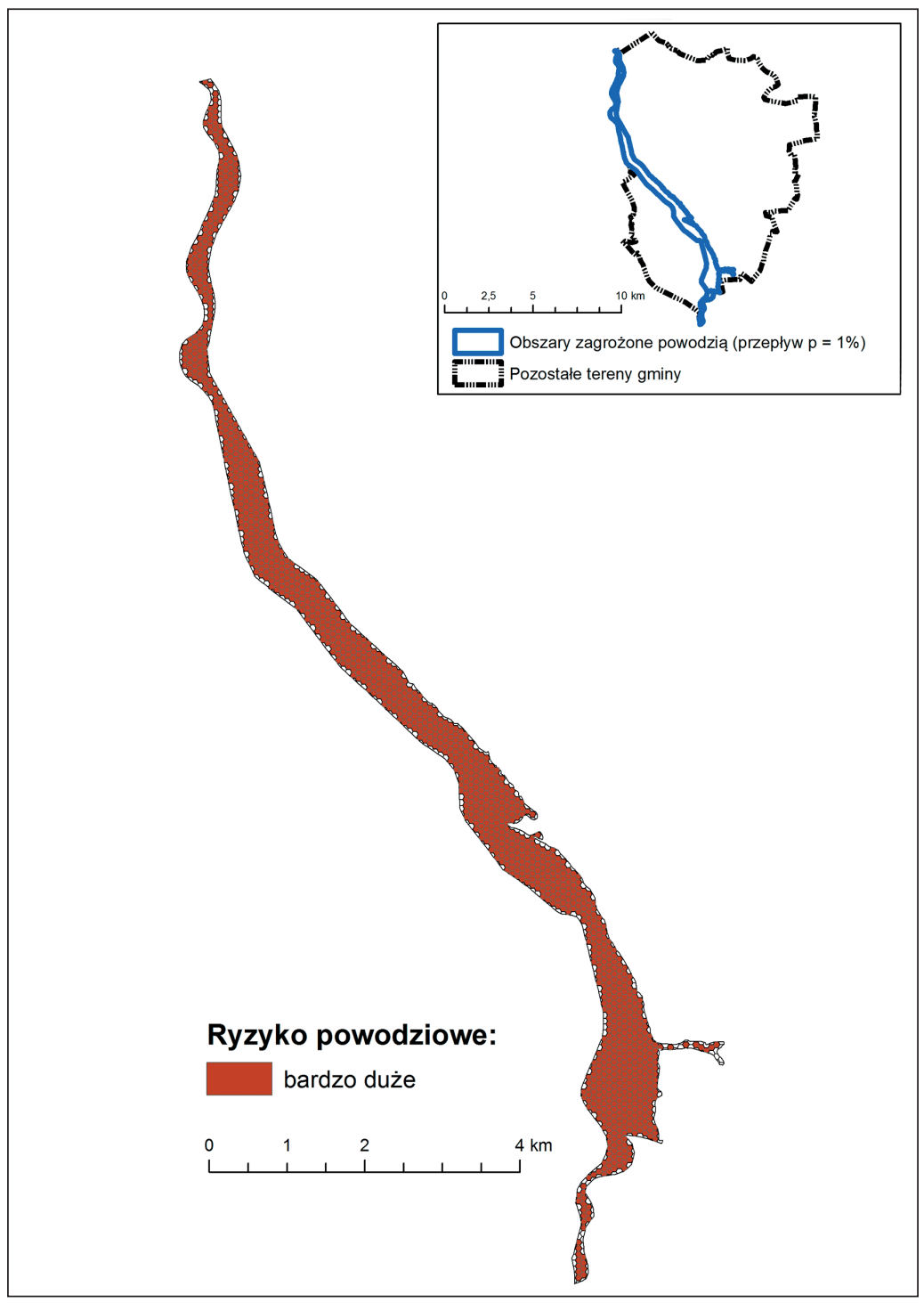

Rycina 5.13. Syntetyczny poziom ryzyka powodziowego według powierzchni zajmowanej przez obiekty i tereny wyodrębnionych kategorii na terenie szczególnego zagrożenia powodzią - przykład Uniejowa Źródło: opracowanie własne, 2013

też przeanalizowano syntetyczny poziom ryzyka w gminach, ze względu na zróżnicowanie obiektów i terenów przypisanych do poszczególnych kategorii, na terenach zalewowych. W tej klasyfikacji brano pod uwagę miejsce danej gminy według poziomu ryzyka powodziowego w każdej wyodrębnionej kategorii (tabela 5.12). 
Pozycja gminy oznaczała liczbę punktów: im mniej, tym wyższy poziom ryzyka ogółem. W tym przypadku największe ryzyko jest w Łowiczu oraz Tomaszowie Mazowieckim (mieście) (rycina 5.14). Klasyfikacja ta znacznie lepiej odzwierciedla syntetyczny poziom ryzyka powodziowego. Potwierdza to zarówno analiza aktualnego zagospodarowania, jak i powodzi historycznych. W tych

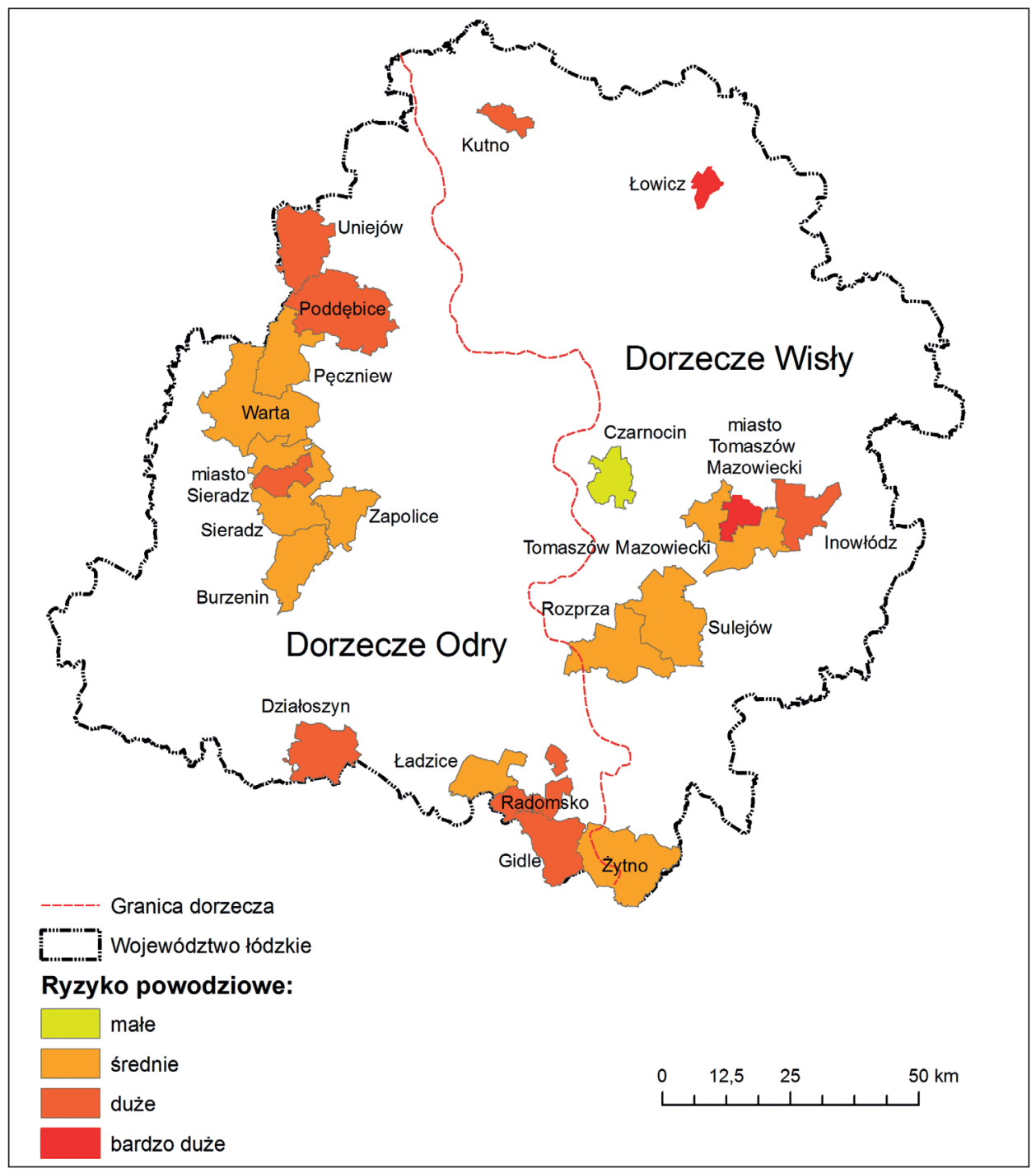

Rycina 5.14. Syntetyczny poziom ryzyka powodziowego w badanych gminach województwa łódzkiego według zróżnicowania obiektów i terenów wyodrębnionych kategorii na terenach zagrożonych powodziami

Źródło: opracowanie własne, 2013 
gminach udział obiektów i terenów narażonych na negatywne konsekwencje jest znaczący w każdej kategorii, a w przypadku Łowicza, co już zostało zauważone we wszystkich przypadkach, przekracza średnią arytmetyczną dla badanych gmin.

Na obszarze Łowicza dno doliny Bzury jest bardzo szerokie, w szczególności w zachodniej i wschodniej części, tam też lokalizowana jest zabudowa. Centralna część równiny zalewowej w granicach administracyjnych miasta chroniona jest przed powodzią wałami. Konflikt zagospodarowania zaznacza się również na obszarze zawala, jednak autorka nie analizowała tego terenu. Tomaszów Mazowiecki to miasto, na którym do Pilicy uchodzą mniejsze rzeki, w związku z czym dno doliny osiąga tu znaczne rozmiary, ok. 1,7 km (Trzmiel 1986). Sprzyja to lokalizowaniu zabudowy. Istnienie mniejszych rzek, w szczególności Czarnej, Piasecznicy, a także położenie poniżej zbiornika Sulejów stwarza wśród użytkowników tych obszarów poczucie bezpieczeństwa. Wszystko to doprowadziło do zabudowy tych terenów oraz wzrostu związanych z tym potencjalnych, negatywnych konsekwencji w przypadku nadejścia powodzi.

Tabela 5.12. Syntetyczny poziom ryzyka powodziowego w badanych gminach województwa łódzkiego według zróżnicowania obiektów i terenów przypisanych do wyodrębnionych kategorii ryzyka

\begin{tabular}{|c|l|c|}
\hline Lp. & \multicolumn{1}{|c|}{ Gmina } & $\begin{array}{c}\text { Liczba punktów ogólem uzyskana we } \\
\text { wszystkich rankingach poziomu ryzyka } \\
\text { powodziowego }\end{array}$ \\
\hline 1. & Łowicz & 18 \\
\hline 1. & Tomaszów Mazowiecki (miasto) & 18 \\
\hline 3. & Kutno & 23 \\
\hline 4. & Działoszyn & 24 \\
\hline 5. & Uniejów & 26 \\
\hline 6. & Poddębice & 33 \\
\hline 7. & Gidle & 35 \\
\hline 8. & Inowłódz & 37 \\
\hline 9. & Radomsko & 38 \\
\hline 10. & Sieradz (miasto) & 40 \\
\hline 11. & Żytno & 42 \\
\hline 12. & Burzenin & 43 \\
\hline 12. & Tomaszów Mazowiecki (gmina wiejska) & 43 \\
\hline 14. & Warta & 48 \\
\hline 15. & Pęczniew & 51 \\
\hline 16. & Sulejów & 52 \\
\hline 16. & Zapolice & 52 \\
\hline
\end{tabular}


Tabela $5.12(\mathrm{~cd}$.

\begin{tabular}{|c|l|c|}
\hline Lp. & \multicolumn{1}{|c|}{ Gmina } & $\begin{array}{c}\text { Liczba punktów ogółem uzyskana we } \\
\text { wszystkich rankingach poziomu ryzyka } \\
\text { powodziowego }\end{array}$ \\
\hline 16. & Sieradz (gmina wiejska) & 52 \\
\hline 19. & Ladzice & 54 \\
\hline 20. & Rozprza & 57 \\
\hline 21. & Czarnocin & 62 \\
\hline
\end{tabular}

Objaśnienia: na rycinie 5.14 poszczególnymi kolorami oznaczono gminy, przypisane do określonego poziomu ryzyka powodziowego według zróżnicowania obszarów zagrożonych powodziami: bardzo duże ryzyko 0-20 pkt, duże 21-40 pkt, średnie 41-60 pkt, małe > 60 pkt.

Źródło: opracowanie własne, 2013.

Analiza poziomu ryzyka powodziowego jest niezwykle istotna i umożliwia prowadzenie odpowiedniej polityki w zakresie ochrony przeciwpowodziowej przez jednostki administracji rządowej oraz samorządowej. W tym celu cenna jest znajomość zarówno ogólnego poziomu ryzyka powodziowego, jak i jego zróżnicowania w obrębie terenu szczególnego zagrożenia powodzią. Dzięki temu wiadomo, które miejsca są w szczególności narażone na negatywne konsekwencje.

\subsection{Porównanie wyników oceny ryzyka powodziowego}

Zarówno metoda wykorzystana w Planie operacyjnym ochrony przed powodzia, jak i zaproponowana przez autorkę dotyczą oceny poziomu ryzyka powodziowego. Jednak wyniki uzyskane na ich podstawie znacząco się różnią. Wynika to z odmiennych podejść do tego zagadnienia. Metodologia zaproponowana przez autorkę opierała się tylko o tereny wody $1 \% \mathrm{w}$ wybranych gminach, co jest zgodne $\mathrm{z}$ aktualnie obowiązującymi przepisami, jednak nie odpowiada uwarunkowaniom przyrodniczym szerokich den dolinnych Polski Środkowej. Ocena poziomu ryzyka dokonana została jedynie na podstawie analizy zagospodarowania, bez wykorzystania chociażby liczby ludności. Zostało to pośrednio uwzględnione poprzez powierzchnię budynków mieszkalnych, zlokalizowanych na obszarach zalewowych. Nie wzięto pod uwagę natomiast środków ochrony przed powodzią, czyli wałów przeciwpowodziowych czy zbiorników retencyjnych. Uwzględniono w niej jednak środowisko przyrodnicze i straty ekonomiczne (funkcję strat). Ocenę strat podano tylko dla jednego wskaźnika wrażliwości - głębokości wody w przedziale $0,5-2 \mathrm{~m}$, przy czym należy podkreślić, że szkody powodziowe zależą od wielu czynników, do których zalicza się m.in.: prędkość przepływu, czas trwania powodzi, zanieczyszczenia, informację (ostrzeżenia powodziowe) itp. 
(Nicholas i in. 2001; Kelman, Spence 2004). Dokonano zróżnicowania ryzyka powodziowego na obszarze wody 100-letniej danej gminy oraz dodatkowo hierarchii gmin ze względu na jego poziom, co znacząco ułatwia prowadzenie odpowiedniej polityki w zakresie ochrony przeciwpowodziowej.

Metoda zaproponowana przez Wydział Bezpieczeństwa i Zarządzania Kryzysowego objęła cały obszar województwa łódzkiego i była pierwszą próbą jego oceny na tym terenie, co jest niezwykle ważne. Analizę przeprowadzono w oparciu o wyniki ankiet rozesłanych do gmin, które mogły zawyżać potencjalne szkody. Dodatkowo nie sprecyzowano dokładnie pojęcia terenów zalewowych, co mogło doprowadzić do różnic w uzyskanych wynikach. W okresie, kiedy przeprowadzono badania, nie było wyznaczonych terenów potencjalnego zagrożenia powodzią dla dorzecza Odry w granicach województwa łódzkiego, natomiast gminy w ankietach wpisywały obiekty położone poza granicą wody 100-letniej. W metodologii wzięto pod uwagę 9 czynników, przy czym zabrakło rozróżnienia funkcji budynków, uwzględniono natomiast ich gęstość oraz osobno wyodrębniono infrastrukturę wrażliwą. Są to dane, które w niektórych przypadkach mogły się powtarzać. Uwzględniono ponadto zbiorniki retencyjne, które z jednej strony redukują falę kulminacyjną, z drugiej zaś stwarzają zagrożenie w przypadku awarii, dla terenów potencjalnego zagrożenia powodziami. Wśród zaklasyfikowanych do analizy czynników zabrakło tych, które dotyczą środowiska przyrodniczego czy też strat ekonomicznych. Nie uwzględniono funkcji strat dla określonej głębokości wody, co jest najczęściej wykorzystywane w procesie szacowania szkód bezpośrednich (Merz, Thieken 2004).

Tabela 5.13. Klasyfikacja gmin województwa łódzkiego ze względu na syntetyczny poziom ryzyka powodziowego

\begin{tabular}{|c|l|c|l|}
\hline \multicolumn{2}{|c|}{ Autorska metoda } & \multicolumn{2}{c|}{$\begin{array}{c}\text { Metoda Wydziału Bezpieczeństwa } \\
\text { i Zarządzania Kryzysowego }\end{array}$} \\
\hline 1p. & \multicolumn{1}{|c|}{ gmina } & $1 p$. & \multicolumn{1}{c|}{ gmina } \\
\hline 1. & Lowicz & 1. & Tomaszów Mazowiecki (miasto) \\
\hline 1. & Tomaszów Mazowiecki (miasto) & 2. & Warta \\
\hline 3. & Kutno & 3. & Radomsko \\
\hline 4. & Działoszyn & 4. & Sieradz (miasto) \\
\hline 5. & Uniejów & 5. & Sulejów \\
\hline 6. & Poddębice & 6. & Lowicz \\
\hline 7. & Gidle & 7. & Poddębice \\
\hline 8. & Inowłódz & 8. & Żytno \\
\hline 9. & Radomsko & 9. & Kutno \\
\hline 10. & Sieradz (miasto) & 10. & Pęczniew \\
\hline 11. & Żytno & 11. & Inowłódz \\
\hline
\end{tabular}


Tabela 5.13 (cd.)

\begin{tabular}{|c|l|c|l|}
\hline \multicolumn{2}{|c|}{ Autorska metoda } & \multicolumn{2}{c|}{$\begin{array}{c}\text { Metoda Wydziału Bezpieczeństwa } \\
\text { i Zarządzania Kryzysowego }\end{array}$} \\
\hline lp. & \multicolumn{1}{|c|}{ gmina } & lp. & \multicolumn{1}{c|}{ gmina } \\
\hline 12. & Burzenin & 12. & Sieradz (gmina wiejska) \\
\hline 12. & Tomaszów Mazowiecki (gmina wiejska) & 13. & Burzenin \\
\hline 14. & Warta & 14. & Tomaszów Mazowiecki (gmina wiejska) \\
\hline 15. & Pęczniew & 15. & Rozprza \\
\hline 16. & Sulejów & 16. & Ladzice \\
\hline 16. & Zapolice & 17. & Działoszyn \\
\hline 16. & Sieradz (gmina wiejska) & 18. & Gidle \\
\hline 19. & Ladzice & 19. & Czarnocin \\
\hline 20. & Rozprza & 20. & Uniejów \\
\hline 21. & Czarnocin & 21. & Zapolice \\
\hline
\end{tabular}

Źródło: opracowanie własne, 2013.

Największe rozbieżności w uzyskanych wynikach dotyczą pięciu gmin: Uniejowa, Działoszyna, Warty, Gidle i Sulejowa (tabela 5.13). 


\section{WNIOSKI}

W pracy podjęto problematykę zagospodarowania terenów zagrożonych powodziami w gminach województwa łódzkiego. Z punktu widzenia ochrony przed powodzią najistotniejsze znaczenie miała analiza stopnia zainwestowania tych obszarów oraz wskazanie miejsc szczególnie narażonych na negatywne konsekwencje, co jest kluczowe w ich właściwej ochronie. W ramach prowadzonych badań skoncentrowano się na ocenie poziomu ryzyka powodziowego, wynikającego ze sposobu zagospodarowania terenów zagrożonych powodziami. Umożliwiło to wyciągnięcie następujących wniosków:

1. Na obszarach zagrożonych powodziami w badanych gminach dominują tereny wolne od zabudowy, w szczególności rolne, co jest właściwe z punktu widzenia ochrony przed powodzią. Zabudowa stanowi niewielki udział, jednak wskutek jej lokalizacji wzrasta ryzyko powodziowe. Największa pozioma intensywność użytkowania terenów zagrożonych powodziami cechuje Tomaszów Mazowiecki (miasto), Kutno i Łowicz.

2. Obiekty o znaczeniu społecznym oraz obiekty zagrażające środowisku przyrodniczemu i ludziom największą powierzchnię zajmują w gminach, w których równiny zalewowe są szerokie i nie zostały podzielone wałami przeciwpowodziowymi - Gidle (zabudowa mieszkaniowa), Łowicz, oraz w dolinach mniejszych rzek - Tomaszów Mazowiecki (miasto), Kutno.

3. Najwyższy syntetyczny poziom ryzyka powodziowego ze względu na powierzchnię zajmowaną przez obiekty i tereny poszczególnych kategorii ryzyka jest związany $\mathrm{z}$ istnieniem terenów cennych przyrodniczo (występujących $\mathrm{w}$ gminach wiejskich i miejsko-wiejskich) w Uniejowie, Warcie i Żytnie.

4. Syntetyczny poziom ryzyka powodziowego ze względu na zróżnicowanie obiektów i terenów poszczególnych kategorii jest najwyższy w Łowiczu oraz Tomaszowie Mazowieckim (mieście). Na obszarze Łowicza dno doliny Bzury jest bardzo szerokie, zwłaszcza w zachodniej i wschodniej części, tam też lokalizowana jest zabudowa. W Tomaszowie Mazowieckim do Pilicy uchodzą trzy mniejsze rzeki, w związku z czym dno doliny osiąga tu znaczne rozmiary. Istnienie mniejszych rzek, w szczególności Czarnej, Piasecznicy oraz położenie poniżej zbiornika Sulejów wywołuje wśród użytkowników tych obszarów poczucie bezpieczeństwa i doprowadza do zabudowy równin zalewowych. 
5. Wypracowana metoda pozwala $\mathrm{w}$ granicach terenów narażonych na możliwość wystąpienia powodzi na właściwe wyznaczenie miejsc szczególnie zagrożonych oraz ich zróżnicowanie ze względu na poziom ryzyka. Ma ona szczególne znaczenie w przypadku regionów, na których powodzie nie generują ogromnych szkód i brak jest dokładnych danych o ich skutkach, w ujęciu historycznym. Na podstawie analizy aktualnego zagospodarowania można wnioskować o poziomie ryzyka, co jest bardzo ważne w prowadzeniu właściwej polityki w zakresie ochrony przeciwpowodziowej.

Przedstawione w pracy wnioski mogą przyczynić się do zwiększenia efektywności zarządzania ryzykiem powodziowym. 


\section{BIBLIOGRAFIA}

Apel H., Aronica G. T., Kreibich H., Thieken A. H., 2009, Flood risk analyses - how detailed do we need to be?, „Natural Hazards”, vol. 49, no. 1, s. 79-98.

Arkuszewski A., 1994, Ochrona przed powodzia, „Gospodarka Wodna”, nr 6, s. 122-124.

Bac M., 2011, Tradycja i innowacje w zarzadzaniu ryzykiem powodziowym w Polsce, ,Zeszyty Naukowe Małopolskiej Wyższej Szkoły Ekonomicznej w Tarnowie”, nr 19, s. 21-32.

Bajkiewicz-Grabowska E., Mikulski Z., 1999, Hydrologia ogólna, PWN, Warszawa.

Bajorek J., 2001, Wdrażanie rozwiazań proponowanych w planach: założenia i problemy praktyczne, „Gospodarka Wodna”, nr 8, s. 337-338.

Balcerski W., 1947, Powódź wiosenna 1947 roku, „Gospodarka Wodna”, nr 2, s. 46.

Barczyk A., Bogdanowicz E., Dobrzyńska I., Drezińska B., Fal. B., Kruszewski A., Ośródka K., Szturc J., 1999, Przebieg wezbrania w dorzeczu Wisty, [w:] J. Grela, H. Słota, J. Zieliński (red.), Dorzecze Wisty monografia powodzi lipiec 1997, IMGW, Warszawa, s. 45-72.

Bartnik A., Jokiel P., 2012, Geografia wezbrań i powodzi rzecznych, Wydawnictwo Uniwersytetu Łódzkiego, Łódź.

Batog A., 2007, Wpływ warunków geotechnicznych na katastrofę obwałowania, „Geoinżynieria: Drogi Mosty Tunele", nr 2, http://wydawnictwo.inzynieria.com (3.02.2015).

Biuro Planowania Przestrzennego Województwa Łódzkiego, Informacje szczegółowe.

Bobiński E., Żelaziński J., 1996, Czy można przerwać błędne koło ochrony przeciwpowodziowej?, „Gospodarka Wodna”, nr 4, s. 99-107.

Bogdańska-Warmuz R., Grela J., Konieczny R., Siudak M., 2000, Systemy ostrzeżeń powodziowych, [w:] M. Maciejewski (red.), Model kompleksowej ochrony przed powodzia w obszarze dorzecza górnej Wisty na przykładzie województwa małopolskiego, IMGW, Kraków (CD-ROM).

Borowska-Stefańska M., 2013, Zagospodarowanie terenów zagrożonych powodziami w matych miastach województwa tódzkiego, [w:] K. Heffner, M. Twardzik (red.), Nowoczesne instrumenty polityki rozwoju lokalnego - zastosowanie i efekty w matych miastach, „Studia Ekonomiczne. Zeszyty Naukowe Uniwersytetu Ekonomicznego w Katowicach”, s. 323-332.

Borys M., 2007, Przepisy $i$ wymogi oraz aktualny stan obwałowań przeciwpowodziowych w Polsce, „Woda - Środowisko - Obszary Wiejskie”, t. 7, z. 2a (20), s. 25-44.

Borys M., 2011, Ocena stanu technicznego i przydatności urzadzeń przeciwpowodziowych wobszarach problemowych $w$ dorzeczu Wisty środkowej - stan dotychczasowej wiedzy i dalsze kierunki prac, IMUZ, Falenty.

Borys M., 2013, Zasady wykonywania corocznych kontroli stanu technicznego wałów przeciwpowodziowych, „Gospodarka Wodna”, nr 7, s. 260-266.

Borys M., Mosiej K., 2008, Oceny stanu technicznego obwałowań przeciwpowodziowych, IMUZ, Falenty.

Bromek K., Mydel R., 1972, Uwagi metodyczne do opracowania szczegółowej mapy użytkowania ziemi przestrzeni miejskiej, „Folia Geopgraphica. Seria Geographica-Oeconomica”, vol. 5, Kraków, s. 149-160. 
Brzeziński M., 1990a, Szczegółowa mapa geologiczna Polski, 1:50 000, arkusz 555-Łowicz, Państwowy Instytut Geologiczny, Warszawa.

Brzeziński M., 1990b, Szczegółowa mapa geologiczna Polski, 1:50 000, arkusz 702-Sulejów, Państwowy Instytut Geologiczny, Warszawa.

CA WALUP (The California Water and Land Use Partnership), 2009, How Urbanization Affects the Water Cycle, http://www.coastal.ca.gov/nps/watercyclefacts.pdf (20.02. 2015).

Chojnacki J., 1994, Wskaźniki strat powodziowych, „Gospodarka Wodna”, nr 10, s. 227-231.

Chojnacki J., 2000, Szacowanie strat powodziowych, [w:] M. Maciejewski (red.), Model kompleksowej ochrony przed powodzia w obszarze dorzecza górnej Wisty na przykladzie województwa matopolskiego, IMGW, Kraków (CD-ROM).

Chow V.T., 1959, Open Channel Hydraulics, McGraw Hill, New York.

Ciupa T., 2009, Wpływ zagospodarowania terenu na odplyw i transport fluwialny w matych zlewniach na przykładzie Sufragańca i Silnicy, Uniwersytet Humanistyczno-Przyrodniczy Jana Kochanowskiego, Kielce.

Crichton, D., 1999, The risk triangle, [w:] J. Ingleton, Natural Disaster Management, Tudor Rose, London, s. 102-103.

Crichton, D., 2007, What can cities do to increase resilience?, „Philosophical Transactions of the Royal Society", vol. 365, s. 2731-2739.

Czoch K., Jankowski W., Kulesza K., Lebiecki P., 2011, Analiza skuteczności watów przeciwpowodziowych, [w:] M. Maciejewski, M. S. Ostojski, T. Walczykiewicz (red.), Dorzecze Wisty monografia powodzi maj-czerwiec 2010, IMGW PIB, Warszawa, s. 149-158.

De La Cruz-Reyna S., 1996, Long-term probabilistic analysis of future explosive eruptions, [w:] R. Scarpa, R.I. Tilling, Monitoring and Mitigation of Volcano Hazards, Springer-Verlag, Berlin-Heidelberg-New York, s. 599-629.

Dębski K., 1950, Obwałowanie rzek jako środek ochrony przed powodzia z punktu widzenia hydrologii, „Gospodarka Wodna”, nr 7-8, s. 232-242.

Drożdżal E., Grabowski M., Kondziołka K., Olbracht J., Piórecki M., Radoń R., Ryłko A., 2009, Mapy ryzyka powodziowego - projekt pilotażowy w zlewni Silnicy, „Gospodarka Wodna”, nr 1, s. 19-29.

Drużyńska E., Nachlik E., 2006, Podstawy metodyczne i standardy zintegrowanego planowania w gospodarce wodnej, Politechnika Krakowska, Kraków.

Dubicki A., Przebieg powodzi w dorzeczu górnej i środkowej Odry, 1999, [w:] A. Dubicki, H. Słota, J. Zieliński (red.), Dorzecze Odry monografia powodzi lipiec 1997, IMGW, Warszawa, 1999, s. $61-80$.

Dusza S., Nowak A., 2007, Analiza zmian sieci hydrograficznej na terenie Poznania w ujęciu historycznym [w:] W. Tołoczko (red.), Zagospodarowanie dolin rzecznych, Koło Naukowe Młodych Geografów „Geoholicy”, Łódź, s. 7-16.

Dutta D., Herath S., Musiake K., 2003, A mathematical model for flood loss estimation, „Journal of Hydrology", vol. 277, no. 1, s. 24-49.

Dylik J., 1948, Uksztaltowanie powierzchni i podział na krainy podtódzkiego obszaru, „Acta Geographica Lodziensia", nr 1.

Dyrektywa 2007/60/WE Parlamentu Europejskiego i Rady z dnia 23 października 2007 r. w sprawie oceny ryzyka i zarządzania nim (Dyrektywa Powodziowa).

Fiszer J., Sarna S., 2001, Zagrożenia i ochrona budynków na obszarach zalewowych, „Gospodarka Wodna", nr 8, s. 339-343.

Genovese E., 2006, A Methodological Approach to Land Use-based Flood Damage Assessment in Urban Areas: Prague Case Study, European Communities.

Gorzym-Wilkowski W. A., Miszczuk A., Miszczuk M., Żuk K., 1999, Zarys ekonomiki gminy, Norberlinum, Lublin. 
Granger K., Jones T., Leiba M., Scott G., 1999, Community Risk in Cairns: A Multi-hazard Risk Assessment, AGSO (Australian Geological Survey Organisation) Cities Project, Department of Industry, Science and Resources, Australia.

Green C. H., 2003, Evaluating vulnerability and resilience in flood management, [w:] A. van der Veen, A. L. V. Arellano, J. P. Nordvik (red), In Search of a Common Methodology on Damage Estimation, EUR 20997 EN, European Commission, Ispra.

Grochulski J., 1975, Hydrologiczno-ekonomiczne kryteria oceny wezbrań dla potrzeb ochrony przeciwpowodziowej, „Gospodarka Wodna”, nr 1, s. 14-22.

Grocki R., Eliasiewicz R., 2001, Zagospodarowanie terenów zalewowych, Biuro Koordynacji Projektu Banku Światowego, Wrocław.

Haisig J., Wilanowski S., 2000, Szczegółowa mapa geologiczna Polski, 1:50 000, arkusz 771-Działoszyn, M-34-26-D, Ministerstwo Środowiska i Państwowy Instytut Geologiczny, Warszawa.

Helm P., 1996, Integrated Risk Management for Natural and Technological Disasters, „Tephra”, vol. 15 , no. 1 , s. $4-13$.

Hermańska A., Smyka R., 1987, Szczegółowa mapa geologiczna Polski, 1:50 000, arkusz 811-Żytno, Państwowy Instytut Geologiczny, Warszawa.

ICPR (International Commission for the Protection of the Rhine), 2002, Non-structural Flood Plain Management: Measures and Their Effectiveness, Koblenz, http://www.iksr.org/index.php (20.09.2014).

Instytut Meteorologii i Gospodarki Wodnej PIB, Informacje szczegółowe.

Jewtuchowicz S., 1967, Geneza Pradoliny Warszawsko-Berlińskiej między Nerem i Moszczenica, „Prace Geograficzne IG PAN”, z. 62.

Jokiel P., 2004, Zasoby wodne środkowej Polski na progu XXI wieku, Wydawnictwo Uniwersytetu Łódzkiego, Łódź.

Kelman, I., Spence R., 2004, An overview of flood actions on buildings, „Engineering Geology”, vol. 73 , no. 3-4, s. 297-309.

Kitowski K., Gromada O., 2010, Wdrażanie Dyrektywy Powodziowej Unii Europejskiej w Polsce, [w:] B. Mońka (red.), Zarządzanie zasobami wodnymi w dorzeczu Odry. Materiały z XIII Konferencji ,ODRA 2010”, Kudowa-Zdrój 23-26 maja 2010 r., PZITS, nr 894, s. 23-30.

Kitowski K., 2010, Dyrektywa Powodziowa a prewencyjne planowanie przestrzenne, „Przegląd Komunalny, nr 7, s. 48-51.

Klatkowa H., 1972, Paleogeografia Wyżyny Łódzkiej i obszarów sąsiednich podczas zlodowacenia warciańskiego, „Acta Geographica Lodziensia”, z. 28.

Klatkowa H., 1984, Problematyka rozwoju sieci dolinnej na Wyżynie Łódzkiej na tle paleogeografii obszaru, [w:] Rozwój sieci dolinnej na Wyżynie Łódzkiej w późnym plejstocenie i holocenie, Zakład Badań Czwartorzędu Instytut Geografii Fizycznej i Kształtowania Środowiska UŁ, Łódź 1984, s. 5-11.

Klatkowa H., Załoba M., 1990, Szczegółowa mapa geologiczna Polski, 1:50 000, arkusz 624-Warta, Państwowy Instytut Geologiczny, Warszawa.

Kledyński Z., 2011, Ochrona przed powodzia i jej infrastruktura w Polsce, [w:] Powodzie w Polsce - zniszczenia i profilaktyka, XXV Konferencja Naukowo-Techniczna „Awarie budowlane”, Międzyzdroje 24-27 maja 2011, s. 243-254.

Klimaszewski M., 1994, Geomorfologia, PWN, Warszawa.

Kobojek E, Kobojek S., 2005, Doliny rzeczne regionu łódzkiego, Geneza, cechy przyrodnicze i antropogeniczne przekształcenia, Wydział Nauk Geograficznych UŁ, Łódź.

Kobojek E., 2009, Naturalne uwarunkowania różnych reakcji rzek nizinnych na antropopresję, Wydawnictwo Uniwersytetu Lódzkiego, s. 71-76.

Kobojek E., 2010, Środowisko przyrodnicze dolin rzek nizinnych i kierunki antropogenicznych przekształceń, [w:] B. Więzik (red.), Prawne, administracyjne i środowiskowe uwarunkowania zagospodarowania dolin rzecznych, Wyższa Szkoła Administracji, Bielsko-Biała, s. 41-54. 
Kobojek E., 2013, Problem przestrzennego rozwoju miast $w$ dolinach rzecznych na przyktadzie Łowicz i Uniejowa, [w:] B. Więzik (red.), Prawne, administracyjne i środowiskowe uwarunkowania zagospodarowania dolin rzecznych, Wyższa Szkoła Administracji, Bielsko-Biała, s. $15-26$.

Kondracki J., 1998, Geografia regionalna Polski, PWN, Warszawa.

Konieczny R., Siudak M., 2010, Ograniczanie skutków powodzi, technika a planowanie, KZGW (wykład 2).

Konrad C. P.,2003, Effects of Urban Development on Flood, U.S. Department of the Interior, U.S. Geological Survey, USGS Fact Sheet FS-076-03, http://pubs.usgs.gov/fs/fs07603/ (20.09.2014).

Konwencja w sprawie ochrony światowego dziedzictwa kulturalnego i naturalnego, przyjęta w Paryżu z dnia 16 listopada 1972 r. przez Konferencję Generalna Organizacji Narodów Zjednoczonych dla Wychowania, Nauki i Kultury na jej siedemnastej sesji, 1976, Dz.U., nr 32, poz. 190.

Kryteria oraz skala ocen stanu technicznego i bezpieczeństwa wałów przeciwpowodziowych. Materialy instruktażowe. Procedury 123/7, 2008, IMUZ, Falenty.

Krzemiński T., 1974, Geneza młodoplejstoceńskiej rzeźby glacjalnej w dorzeczu środkowej Warty, „Acta Geographica Lodziensia”, z. 33.

Krzysztofowicz R., Davis D. R., 1983, Category-unit loss functions for flood forecast-response system evaluation, „Water Resources Research”, vol. 19, no. 6, s. 1476-1480.

Kubrak J., Żelazo J., Kozioł A., Kubrak E., Kiczko A., 2014, O usuwaniu roślinności z terenów zalewowych rzek, „Gospodarka Wodna”, nr 3, s. 95-102.

Kurczyński Z., 2012, Mapy zagrożenia powodziowego i mapy ryzyka powodziowego a Dyrektywa Powodziowa, „Archiwum Fotogrametrii, Kartografii i Teledetekcji”, vol. 23, s. 209-217.

Lambor J., 1954, Klasyfikacja typów powodzi i ich przewidywanie, „Gospodarka Wodna”, nr 4, s. $129-133$.

Lambor J., 1962, Gospodarka wodna na zbiornikach retencyjnych, Arkady, Warszawa.

Liszewski S., 1973, Użytkowanie ziemi w miastach województwa opolskiego, Instytut Śląski, Opole.

Liszewski S., 1977, Tereny miejskie a struktura przestrzenna Łodzi, Uniwersytet Łódzki, Łódź.

Liszewski S., 1978, Tereny miejskie. Podziat i klasyfikacja, „Zeszyty Naukowe Uniwersytetu Łódzkiego. Nauki Matematyczno-Przyrodnicze", z. 15.

Liszewski S., 1997, Przestrzeń miejska i jej organizacja, [w:] B. Domański, A. Jackowski (red.), Geografia. Człowiek. Gospodarka, IG UJ, Kraków.

Maciejewski M., Ostojski M.S, Tokarczyk T. (red.), 2011, Dorzecze Odry monografia powodzi 2010, IMGW-Państwowy Instytut Badawczy, Warszawa.

Maciejewski M., Walczykiewicz T., 2010, Powódź-nasze niekonsekwencje, [w:] Forum Naukowo-Techniczne. Powódź 2010, Warszawa.

Mackiewicz S., 2006, Budowa i modernizacja watów przeciwpowodziowych, [w:] Vademecum ochrony przeciwpowodziowej, Gdańsk, s. 237-274.

Majda T., Mirecka M., Wałdykowski P., 2011, Kryteria opracowania typologii terenów narażonych na niebezpieczeństwo powodzi oraz zakresu ustaleń do miejscowych planów zagospodarowania przestrzennego, które należy określić dla tych terenów, Warszawa.

Majda T., Wałdykowski P., Adamczyk J., Grygoruk M., 2012, Typologia terenów narażonych na niebezpieczeństwo powodzi, [w:] Program Bezpieczeństwa Powodziowego w Dorzeczu Wisty Środkowej, Warszawa.

Maksymiuk Z., 1980, Formy alimentacji rzek i ich rola w bilansie wodnym na przyktadzie dorzecza Widawki, „Acta Geographica Lodziensia”, z. 42, s. 102-108.

Merz B., Thieken A. H., 2004, Flood risk analysis: concepts and challenges, „Osterreichische Wasser und Abfallwirtschaft", vol. 56, no. 3-4, s. 27-34. 
Messner F., Meyer V., 2005, Flood damage, vulnerability and risk perception - challenges for flood damage research, UFZ Discussion Paper 13.

Mierzejewska L., 2010, Rozwój zrównoważony miasta. Zagadnienia poznawcze i praktyczne, Wydawnictwo Naukowe Uniwersytetu Adama Mickiewicza, Poznań.

Mikulski Z., 1954, Katastrofalne powodzie w Polsce, „Czasopismo Geograficzne”, t. 25, z. 4, s. $380-396$.

Mikulski Z., 1957, Charakterystyka powodzi w Polsce, „Gospodarka Wodna”, nr 9, s. 424-428.

Mikulski Z., 1962, Występowanie niżówek wezbrań i powodzi w rzekach polskich, „Wiadomości Służby Hydrologicznej i Meteorologicznej", nr 49, s. 3.

Mikulski Z., 1963, Zarys hydrografii Polski, PWN, Warszawa.

Mikulski Z.,1965, Zarys hydrografii Polski, PWN, Warszawa.

Mikulski Z., 1997, Powódź jako odwieczna klęska żywiołowa, „Gospodarka Wodna”, nr 11, s. $364-370$.

Mikulski Z., 1998, Gospodarka wodna, Wydawnictwo Naukowe PWN, Warszawa.

Mileti D. S., 1999, Disasters by Design: A Reassessment of Natural Hazards in the United States, Joseph Henry, Washington.

Mioduszewski W., 1994, Ochrona i ksztaltowanie zasobów wodnych w matych rolniczych zlewniach rzecznych, Materiały informacyjne nr 25, Instytutu Melioracji i Użytków Zielonych, Falenty.

Mioduszewski W., 2010, Ochrona przed powodzia, „Wiadomości Melioracyjne i Łąkarskie”, t. 53, nr 4, s. 152.

Mioduszewski W., 2012, Zjawiska ekstremalne w przyrodzie - susze i powodzie, [w:] A. Lachacz (red.), Wybrane problemy ochrony mokradet, Uniwersytet Warmińsko-Mazurski, Olsztyn, s. $57-74$.

Nachlik E., 2007, Miejsce ochrony przed powodzia w programowaniu rozwoju społeczno-gospodarczego, „Gospodarka Wodna”, nr 7, s. 269-280.

Nachlik E., 2008, Gospodarka wodna w kontekście przestrzeni kraju - rekomendacje dla KPZK, KPZK, Kraków.

Nachlik E., 2011, Wykorzystanie BDOT w ocenie ryzyka powodziowego. Problemy integracji przestrzennych informacji bazodanowych, VII Krakowskie Spotkania z INSPIRE „Georeferencyjne dane przestrzenne w INSPIRE - od zbiorów do usług danych przestrzennych”, Kraków, 12-14 maja 2011.

Nicholas, J., Holt G. D., Proverbs D., 2001, Towards standardizing the assessment of flood damaged properties in the UK, „Structural Survey”, vol. 19, no. 4, s. 163-172.

Ocena zagrożenia powodziowego na obszarze województwa łódzkiego, 2012, Wydział Bezpieczeństwa i Zarządzania Kryzysowego, Łódzki Urząd Wojewódzki, Łódź.

Ostojski M. S., Maciejewski M., Tokarczyk T., 2011, Przedmowa, [w:] M. Maciejewski, M. S. Ostojski, T. Tokarczyk (red.), Dorzecze Odry monografia powodzi maj czerwiec 2010, IMGW, Warszawa, s. 7.

Ostrowski J., Zaniewska M, Wereski, Bogdanowicz E., 2011, Powodzie historyczne w środkowej i dolnej części dorzecza Wisty, [w:] M. Maciejewski, M. S. Ostojski, T. Walczykiewicz (red.), Dorzecze Wisty monografia powodzi maj-czerwiec 2010, Warszawa, s. 83-86.

Parczewski W., 1954, Powódź roztopowa na małych ciekach nizinnych w styczniu 1953 r., „Gospodarka Wodna", nr 4, s 153-156.

Parczewski W., 1960, Warunki występowania nagłych wezbrań na matych ciekach, „Wiadomości Służby Hydrologicznej i Meteorologicznej PIHM", t. 8, z. 3, s. 85-138.

Penning-Rowsell E. C., Johnson C., Tunstall S., Tapsell S., Morris J., Chatterton J., Coker A., Green C., 2003, The Benefits of Flood and Coastal Defence: Techniques and Data for 2003, Flood Hazard Research Centre, Middlesex University.

Plan operacyjny ochrony przed powodzią dla województwa łódzkiego, 2011, Wydział Bezpieczeństwa i Zarządzania Kryzysowego, Łódzki Urząd Wojewódzki, Łódź. 
Plan operacyjny ochrony przed powodzia dla województwa tódzkiego, 2013, Oddział Zarządzania Kryzysowego Wydział Bezpieczeństwa i Zarządzania Kryzysowego, Łódzki Urząd Wojewódzki, Łódź.

Program bezpieczeństwa powodziowego w dorzeczu Wisty Środkowej-założenia, 2011, Warszawa. Programu bezpieczeństwa powodziowego w regionie wodnym środkowej Wisty, 2012, Warszawa.

Radczuk L., Szymkiewicz R., Jełowicki J., Żyszkowska W., Brun J. F., 2001, Wyznaczanie stref zagrożenia powodziowego, Biuro Koordynacji Projektu Banku Światowego, Wrocław.

Randolph J., 2004, Environmental Land Use Planning and Management, Washington: Island Press. Raport roczny o ilościowym i jakościowym stanie watów przeciwpowodziowych oraz raport $w$ zakresie prowadzenia okresowych ocen stanu technicznego obwatowań w ujęciu wojewódzkim i ogólnokrajowym. Część I: Ocena stanu technicznego wałów przeciwpowodziowych i podstawowych budowli wodno-melioracyjnych oraz utworzenie systemu monitorowania urzadzeń przeciwpowodziowych (na zlecenie MRiRW BDGzp-2915A-30/08), 2008, IMUZ Falenty.

Regionalny Zarząd Gospodarki Wodnej w Poznaniu, Informacje szczegółowe.

Regionalny Zarząd Gospodarki Wodnej w Warszawie, Informacje szczegółowe.

Regulski J.,1985, Planowanie przestrzenne, Państwowe Wydawnictwo Ekonomiczne, Warszawa.

Rip W., 1995, Management of water cycle and energy flow for ecosystem control: The energy-transport-reaction (ETR) model, „Ecological Modelling”, vol. 78, s. 61-76.

Rotnicka J., 2011, Gospodarka wodna w świetle uwarunkowań Unii Europejskiej, [w:] Stan gospodarki wodnej w Polsce - problematyka prawna i kompetencyjna (na przykładzie Dolnej Wisty), Materiały z konferencji zorganizowanej przez Parlamentarny Zespół ds. Dróg Wodnych i Turystyki Wodnej 2 czerwca 2011 r. w siedzibie Senatu, Kancelaria Senatu.

Rozporządzenie Ministra Ochrony Środowiska, Zasobów Naturalnych i Leśnictwa z dnia 23 grudnia 1998 r. w sprawie uznania za rezerwat przyrody, 1998, Dz.U., nr 166, poz. 1219.

Rozporzadzenie Ministra Infrastruktury z dnia 26 sierpnia $2003 r$. w sprawie wymaganego zakresu projektu miejscowego planu zagospodarowania przestrzennego, 2003, Dz.U., nr 164, poz. 1587.

Rozporządzenia Ministra Środowiska z dnia 20 kwietnia 2007 r. w sprawie warunków technicznych, jakim powinny odpowiadać obiekty budowlane gospodarki wodnej i ich usytuowanie, 2007, Dz.U., nr 86, poz. 579.

Rozporzadzenie Ministra Środowiska, Ministra Transportu, Budownictwa i Gospodarki Morskiej, Ministra Administracji i Cyfryzacji oraz Ministra Spraw Wewnętrznych z dnia 21 grudnia $2012 r$. w sprawie opracowywania map zagrożenia powodziowego oraz map ryzyka powodziowego, 2013, Dz.U., poz. 104.

Rudnik K., 2012, Charakterystyka zagospodarowania dziatek zagrodowych w gospodarstwach specjalistycznych, „Problemy Inżynierii Rolniczej”, t. 1, z. 75, s. 25-31.

Runge J, 2007, Metody badań w geografii społeczno-ekonomicznej-elementy metodologii, wybrane narzędzia badawcze, Wydawnictwo Uniwersytetu Śląskiego, Katowice.

Sanders, C. H., Phillipson M. C., 2003, UK adaptation strategy and technical measures: The impacts of climate change on buildings, „Building Research and Information”, vol. 31, s. 210-221.

Sayers P. B., Gouldby B. P., Simm J. D., Meadowcroft I., Hall J., 2002, Risk Performance and Uncertainty in Flood and Coastal Defence - A Review, R\&D Technical Report FD2302/TR1 (HR Wallingford Report SR587), Crown copyright, London.

Sieradzka-Stasiak A., 2010, Prewencyjna przestrzenna lekarstwem na negatywne skutki powodzi, „Przegląd Komunalny”, nr 7, s. 52-54.

Słonecka A., Jaglak E, Goryszewska E., Kołakowska J., Ulanicka E., 2008, Zagospodarowanie przestrzenne dolin rzecznych a zagrożenie powodziowe województwa mazowieckiego, Mazowieckie Biuro Planowania Regionalnego, Warszawa.

Słysz K., Pawłowska K., 2010, Powodzie a planowanie przestrzenne, [w:] Forum Naukowo-Techniczne. Powódź 2010, Warszawa, s. 174-186. 
Smith D. I., 1981, Actual and potential flood damage: A case study for urban Lismore, NSW, Australia, „Applied Geography”, vol. 1, s. 31-39.

Smith D. I., 1994, Flood damage estimation: A review of urban stage-damage curves and loss functions, „Water SA”, vol. 20, no. 3, s. 231-238.

Smith K., Ward R., 1998, Floods: Physical Processes and Human Impact, John Wiley \& Sons, Chichester.

Sowiński M., 2008, Szkody powodziowe jako element wyznaczania ryzyka, „Infrastruktura i Ekologia Terenów Wiejskich”, nr 7, s. 121-130.

Stachy J., Fal B., Dobrzyńska I., Hołdakowska J., 1996, Wezbrania rzek polskich w latach 19511990. Materiaty badawcze IMGW, „Hydrologia i Oceanologia”, t. 20.

Starkel L., 1998, Funkcja powodzi w środowisku przyrodniczym dorzecza górnej Wisty, [w:] L. Starkel, J. Grela (red.), Powódź w dorzeczu górnej Wisty w lipcu 1997 roku, PAN, Kraków, s. 9-20.

Starkel L., 1999, Geografia Polski środowisko przyrodnicze, Wydawnictwo Naukowe PWN, Warszawa.

Stenchion, P., 1997, Development and disaster management, „The Australian Journal of Emergency Management", vol. 12, no. 3, s. 40-44.

Studium uwarunkowań i kierunków zagospodarowania przestrzennego miasta Łowicza, 2003.

Studium uwarunkowań i kierunków zagospodarowania przestrzennego miasta Tomaszowa Mazowieckiego z 18 grudnia 2009.

Studium uwarunkowań i kierunków zagospodarowania przestrzennego miasta Kutna, 2012.

Tadeuszewski B., Wilczak M., 2011, Przebieg powodzi w zlewni Warty, [w:] M. Maciejewski, M. S. Ostojski, T. Tokarczyk (red.), Dorzecze Odry monografia powodzi 2010, Państwowy Instytut Badawczy, Warszawa, s. 63-68.

Thieken A. H., Müller M., Kreibich H., Merz, B., 2005, Flood damage and influencing factors: New insights from the August 2002 flood in Germany, „Water Resources Research”, vol. 41.

Trzmiel B., 1986, Szczegółowa mapa geologiczna Polski, 1:50 000, arkusz 667-Tomaszów Mazowiecki, Państwowy Instytut Geologiczny, Warszawa.

Tyszka Z., 1954, Powodzie w Polsce i ochrona przed nimi w zarysie historycznym, „Gospodarka Wodna", nr 4.

UN DHA (United Nations Department of Humanitarian Affairs), 1992, Internationally Agreed Glossary of Basic Terms Related to Disaster Management, Geneva.

Ustawa z dnia 21 marca 1991 r. o obszarach morskich Rzeczypospolitej Polskiej i administracji morskiej, 1991, Dz.U., nr 32, poz. 131.

Ustawa z dnia 7 lipca 1994 r. Prawo budowlane, 1994, Dz.U., nr 89, poz. 414; Dz.U. 2006, nr 156, poz. 1118 , nr 170, poz. 1217.

Ustawa z dnia 21 listopada 1996 r. o muzeach, 1997, Dz.U., nr 5, poz. 24.

Ustawa z dnia 21 sierpnia 1997 r. o gospodarce nieruchomościami, 1997, Dz.U., nr 115, poz. 741.

Ustawa z dnia 27 kwietnia 2001 r. Prawo ochrony środowiska, 2008, Dz.U., nr 25, poz. 150 z późn. zm.

Ustawa z dnia 18 lipca 2001 r. Prawo wodne, 2001, Dz.U., nr 115 poz. 1229 z późn. zm.; 2012, poz. $145 \mathrm{z}$ późn. $\mathrm{zm}$.

Ustawa z dnia 27 marca 2003 r. o planowaniu i zagospodarowaniu przestrzennym, 2003, Dz.U., nr 80, poz. 717.

Ustawa z dnia 23 lipca 2003 r. o ochronie zabytków i opiece nad zabytkami, 2003, Dz.U., nr 162, poz. 1568 z późn. zm.

Walczykiewicz T., Biedroń I., 2013, Zagospodarowanie dolin rzecznych w świetle zarzadzania ryzykiem powodziowym, [w:] B. Więzik (red.), Prawne, administracyjne i środowiskowe uwarunkowania zagospodarowania dolin rzecznych, Wyższa Szkoła Administracji, Bielsko-Biała, s. $145-154$. 
Wicher-Dysarz J., Dysarz T., 2007, Wpływ rezerwatu przyrody na eksploatację zbiornika nizinnego Jeziorsko, „Infrastruktura i Ekologia Terenów Wiejskich”, nr 4, s. 179-186.

Więzik B., 2010, Wpływ zagospodarowania międzywala na zagrożenia powodziowe, [w:] B. Więzik (red.), Prawne, administracyjne i środowiskowe uwarunkowania dolin rzecznych, Wyższa Szkoła Administracji, Bielsko-Biała, s. 227-242.

Wind H. G., Nierop T. M., de Blois C. J., de Kok J. L., 1999, Analysis of flood damages from the 1993 and 1995 meuse flood, „Water Resources Research”, vol. 35, no. 11, s. 3459-3465.

Wojewódzki Program małej retencji dla województwa łódzkiego, 2005, WZMiUW, Warszawa.

Wojewódzki Zarząd Melioracji i Urządzeń Wodnych w Łodzi, Informacje szczegółowe.

Wołoszyn E., 2006, Oddziaływanie powodzi na środowisko, [w:] Vademecum ochrony przeciwpowodziowej, Gdańsk, s. 125-158.

Wołyński W., Górecki T., Analiza skupień, http://stat.gov.pl/cps/rde/xbcr/pts/WAS_wyklad_6_marca_2013_prezentacja.pdf (10.10.2014).

WORP, 2011, Raport $z$ wykonania wstepnej oceny ryzyka powodziowego, Projekt ISOK - Informatyczny System Osłony Kraju przed Nadzwyczajnymi Zagrożeniami, tytuł zadania 1.3.1: Wstępna ocena ryzyka powodziowego, IMGW, KZGW, Warszawa.

Wstęna ocena ryzyka powodziowego, 2011, KZGW, Warszawa.

Wytyczne techniczne Baza Danych Topograficznych (TBD), 2008, Główny Geodeta Kraju.

Zagrożenia okresowe występujace w Polsce, 2010, Wydział Analiz i Prognoz Biura Monitorowania i Analizy Zagrożeń Rządowego Centrum Bezpieczeństwa, http://rcb.gov.pl/wp-content/ uploads/2011/02/zagr_okres1.pdf (21.01.2014).

Zaleski J, 2010, Refleksje na temat ochrony przed powodzia aglomeracji wrocławskiej w 1997 i 2010 roku oraz propozycje krajowych działań prewencyjnych, [w:] Forum Naukowo-Techniczne. Powódź 2010, Warszawa, s. 103-115.

Załacznik nr 21 do Programu bezpieczeństwa powodziowego w regionie wodnym środkowej Wisty, Charakterystyka terenów zagrożonych skutkami zalewania, 2012, Warszawa.

Ziomek J., Baliński W., 2007, Szczegółowa mapa geologiczna Polski, 1:50 000, arkusz 661-Sieradz, M-34-14-A, Ministerstwo Środowiska i Państwowy Instytut Geologiczny, Warszawa.

Ziółkowski L., Szczęśniak M., Paluszkiewicz B., Będkowski M., 2011, Narzędzie GIS jako podstawowy instrument pomocniczy wykorzystywany przy wyznaczaniu zasięgu stref zalewowych, „Gospodarka Wodna”, nr 2, s. 5-62.

\section{Strony internetowe}

http://tomaszowmazowiecki.naszemiasto.pl/artykul/to-nie-oni-byli-winni-powodzi-sprzed-5-lat, 338740,art,t,id,tm.html (3.02.2015).

http://www.kzgw.gov.pl/Dyrektywa-Powodziowa.html, Oficjalna strona Krajowego Zarządu Gospodarki Wodnej (27.11.2013). 


\section{SPIS TABEL}

Tabela 1.1. Klasyfikacja poziomu ryzyka powodziowego ……........................................... 25

Tabela 1.2. Wartości liczby bazowej dla poszczególnych stopni ryzyka powodziowego .......... 26

Tabela 1.3. Stopnie ryzyka powodziowego dla gmin województwa łódzkiego .......................... 26

Tabela 1.4. Stopień utraty majątku ze względu na funkcję oraz głębokość wody ...................... 30

Tabela 1.5. Wartość utraty majątku w województwie łódzkim ze względu na klasy użytkowania terenu

Tabela 1.6. Kryteria oceny syntetycznego poziomu ryzyka powodziowego w heksagonie ...... 32

Tabela 2.1. Systematyka typów powodzi …………................................................................. 43

Tabela 2.2. Charakterystyka powodzi w styczniu 1953 r. ............................................................. 49

Tabela 2.3. Powodzie historyczne w gminach województwa łódzkiego o bardzo dużym i dużym wskaźniku ryzyka powodziowego

Tabela 3.1. Wielkość obszarów szczególnego zagrożenia powodzią w badanych gminach województwa łódzkiego

Tabela 3.2. Struktura użytkowania ziemi terenów zagrożonych powodziami w badanych gminach województwa łódzkiego

Tabela 3.3. Struktura zagospodarowania terenów zagrożonych powodziami w wyodrębnionych grupach gmin województwa łódzkiego

Tabela 4.1. Długość wałów przeciwpowodziowych w województwie łódzkim z uwzględnieniem gmin o dużym i bardzo dużym wskaźniku ryzyka powodziowego

Tabela 4.2. Klasyfikacja obwałowań przeciwpowodziowych

Tabela 4.3. Zbiorniki wodne w województwie łódzkim

Tabela 4.4. Parametry zbiorników wodnych zlokalizowanych w gminach województwa łódzkiego o dużym i bardzo dużym wskaźniku ryzyka powodziowego

Tabela 5.1. Kategorie ryzyka powodziowego według powierzchni i wielkości strat w granicach wody $1 \%$ badanych gmin województwa łódzkiego

Tabela 5.2. Udział obiektów i terenów poszczególnych kategorii ryzyka powodziowego oraz wielkość strat $\mathrm{w} \mathrm{z} / \mathrm{m}^{2} \mathrm{w}$ granicach wody 100-letniej badanych gmin województwa łódzkiego

Tabela 5.3. Wielkość obszarów i terenów poszczególnych kategorii ryzyka powodziowego w granicach wody 100-letniej badanych gmin województwa łódzkiego w stosunku do średniej arytmetycznej

Tabela 5.4. Klasyfikacja kategorii ryzyka powodziowego na terenach zalewowych według powierzchni zajmowanej w poszczególnych gminach

Tabela 5.5. Udział heksagonów o określonym poziomie ryzyka powodziowego w danej kategorii na obszarach zagrożonych powodziami w badanych gminach województwa łódzkiego

Tabela 5.6. Hierarchia gmin według poziomu ryzyka powodziowego w grupie obiektów o znaczeniu społecznym 
Tabela 5.7. Hierarchia gmin według ryzyka powodziowego w grupie obiektów zagrażających środowisku przyrodniczemu oraz ludziom

Tabela 5.8. Hierarchia gmin według ryzyka powodziowego ze względu na potencjalne straty materialne

Tabela 5.9. Hierarchia gmin według ryzyka powodziowego w grupie obiektów dziedzictwa kulturowego i terenów cennych przyrodniczo

Tabela 5.10. Udział heksagonów o określonym poziomie ryzyka w całkowitej powierzchni terenów zagrożonych powodzią w badanych gminach województwa łódzkiego

Tabela 5.11. Hierarchia gmin według syntetycznego poziomu ryzyka powodziowego (ze względu na powierzchnię zajmowaną przez obszary i obiekty różnych kategorii)

Tabela 5.12. Syntetyczny poziom ryzyka powodziowego w badanych gminach województwa łódzkiego według zróżnicowania obiektów i terenów przypisanych do wyodrębnionych kategorii ryzyka

Tabela 5.13. Klasyfikacja gmin województwa łódzkiego ze względu na syntetyczny poziom ryzyka powodziowego 


\section{SPIS RYCIN}

Rycina 1. Tereny zagrożone powodziami w badanych gminach województwa łódzkiego ....... 9

Rycina 1.1. Zależność pomiędzy zagrożeniem a ryzykiem powodziowym ............................. 18

Rycina 1.2. Gminy o dużym i bardzo dużym poziomie ryzyka powodziowego w województwie łódzkim

Rycina 2.1. Sieć rzeczna województwa łódzkiego .................................................................. 40

Rycina 2.2. Dzienne stany wody w Sieradzu w 2005 r., zlewnia rzeki Warty ........................... 44

Rycina 2.3. Dzienne stany wody w miejscowości Kwiatkówek w 2005 r., zlewnia rzeki Bzury

Rycina 2.4. Katastrofalne powodzie w XX i XXI w. na obszarze województwa łódzkiego ..... Rycina 2.5. Liczba powodzi zarejestrowanych w badanych gminach w latach 1947-2010 ..... Rycina 2.6. Udział negatywnych konsekwencji dla zdrowia ludzi, środowiska, dziedzictwa kulturowego i działalności gospodarczej w powodziach w latach 1947-2010 w badanych gminach

Rycina 3.1. Wskaźnik poziomej intensywności zagospodarowania na obszarach zagrożonych powodziami w badanych gminach województwa łódzkiego

Rycina 3.2. Wskaźnik wykorzystania powierzchni na obszarach zagrożonych powodziami w badanych gminach województwa łódzkiego

Rycina 3.3. Wskaźnik terenów wolnych od zabudowy na obszarach zagrożonych powodziami w badanych gminach województwa łódzkiego

Rycina 3.4. Zróżnicowanie terenów zagrożonych powodziami pod względem struktury użytkowania terenów wolnych od zabudowy

Rycina 3.5. Typy terenów wolnych od zabudowy na obszarach zagrożonych powodziami w badanych gminach województwa łódzkiego

Rycina 3.6. Zróżnicowanie terenów zagrożonych powodziami pod względem struktury użytkowania terenów zabudowanych

Rycina 3.7. Typy terenów zabudowanych na obszarach zagrożonych powodziami w badanych gminach województwa łódzkiego

Rycina 3.8. Gminy o podobnej strukturze zagospodarowania terenów zagrożonych powodziami w województwie łódzkim

Rycina 3.9. Bilans użytkowania ziemi terenu wody $1 \% \mathrm{w}$ Tomaszowie Mazowieckim ........... 76

Rycina 3.10. Zagospodarowanie terenu szczególnego zagrożenia powodzią w Tomaszowie Mazowieckim

Rycina 3.11. Zabudowa na obszarze zalewowym w Tomaszowie Mazowieckim .................... 78

Rycina 3.12. Bilans użytkowania ziemi terenu wody 100-letniej w Kutnie .............................. 80

Rycina 3.13. Zagospodarowanie terenu szczególnego zagrożenia powodzią w Kutnie ............ 81

Rycina 3.14. Zabudowa na obszarze zalewowym w Kutnie ................................................ 82

Rycina 3.15. Bilans użytkowania ziemi terenu wody 100-letniej w Łowiczu ......................... 84

Rycina 3.16. Zagospodarowanie terenu szczególnego zagrożenia powodzią w Łowiczu ......... 85 
Rycina 3.17. Zabudowa na obszarze zalewowym w Łowiczu

Rycina 4.1. Wały przeciwpowodziowe w województwie łódzkim

Rycina 4.2. Struktura ilościowa obwałowań w poszczególnych klasach budowli hydrotechnicznych w województwie łódzkim

Rycina 4.3. Struktura ilościowa obwałowań w poszczególnych klasach budowli hydrotechnicznych w Polsce

Rycina 4.4. Klasy wałów przeciwpowodziowych w gminach o dużym i bardzo dużym wskaźniku ryzyka powodziowego

Rycina 4.5. Wiek wałów przeciwpowodziowych w gminach o dużym i bardzo dużym wskaźniku ryzyka powodziowego

Rycina 4.6. Udział obwałowań o podanym czasie eksploatacji (w latach) w ogólnej długości wałów na obszarze badanych gmin województwa łódzkiego

Rycina 4.7. Udział obwałowań o podanym czasie eksploatacji (w latach) w ogólnej długości wałów w Polsce

Rycina 4.8. Stan bezpieczeństwa wałów przeciwpowodziowych na obszarze badanych gmin województwa łódzkiego

Rycina 4.9. Wały przeciwpowodziowe według stanu technicznego w gminach o dużym i bardzo dużym wskaźniku ryzyka powodziowego

Rycina 4.10. Zbiorniki istotne z punktu widzenia ochrony przeciwpowodziowej w granicach gmin województwa łódzkiego o dużym i bardzo dużym wskaźniku ryzyka powodziowego

Rycina 5.1. Obiekty i tereny wszystkich kategorii ryzyka powodziowego w granicach wody 100-letniej w Łowiczu

Rycina 5.2. Obiekty potencjalnie zagrażające środowisku przyrodniczemu oraz ludziom

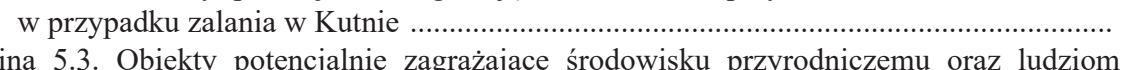
w przypadku zalania w Tomaszowie Mazowieckim ...

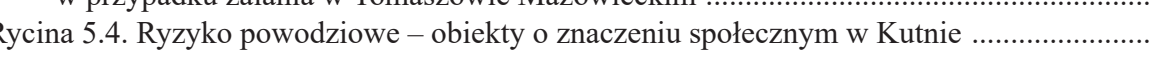

Rycina 5.5. Ryzyko powodziowe - obiekty o znaczeniu społecznym w Radomsku .................

Rycina 5.6. Ryzyko powodziowe - obiekty stwarzające potencjalne zagrożenie dla środowiska przyrodniczego oraz ludzi w przypadku zalania Tomaszowa Mazowieckiego (miasta) .......

Rycina 5.7. Ryzyko powodziowe - obiekty stwarzające potencjalne zagrożenie dla środowiska

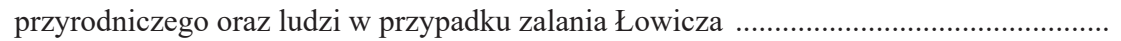

Rycina 5.8. Ryzyko powodziowe - potencjalna utrata majątku w Tomaszowie Mazowieckim ....

Rycina 5.9. Ryzyko powodziowe - potencjalna utrata majątku w Kutnie ..............................

Rycina 5.10. Ryzyko powodziowe - potencjalna utrata majątku w Łowiczu ..........................

Rycina 5.11. Ryzyko powodziowe - potencjalne negatywne konsekwencje dla środowiska przyrodniczego i dziedzictwa kulturowego w Warcie

Rycina 5.12. Syntetyczny poziom ryzyka powodziowego w badanych gminach województwa łódzkiego według powierzchni zajmowanej przez obiekty i tereny wyodrębnionych kategorii na terenach zagrożonych powodziami

Rycina 5.13. Syntetyczny poziom ryzyka powodziowego według powierzchni zajmowanej przez obiekty i tereny wyodrębnionych kategorii na terenie szczególnego zagrożenia powodzią - przykład Uniejowa

Rycina 5.14. Syntetyczny poziom ryzyka powodziowego w badanych gminach województwa łódzkiego według zróżnicowania obiektów i terenów wyodrębnionych kategorii na terenach zagrożonych powodziami 


\section{SPIS FOTOGRAFII}

Fotografia 3.1. Rzeka Wolbórka w Tomaszowie Mazowieckim .......................................... 75

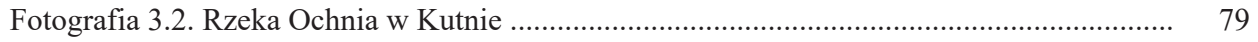

Fotografia 3.3. Rzeka Bzura w Łowiczu ....................................................................... 83 